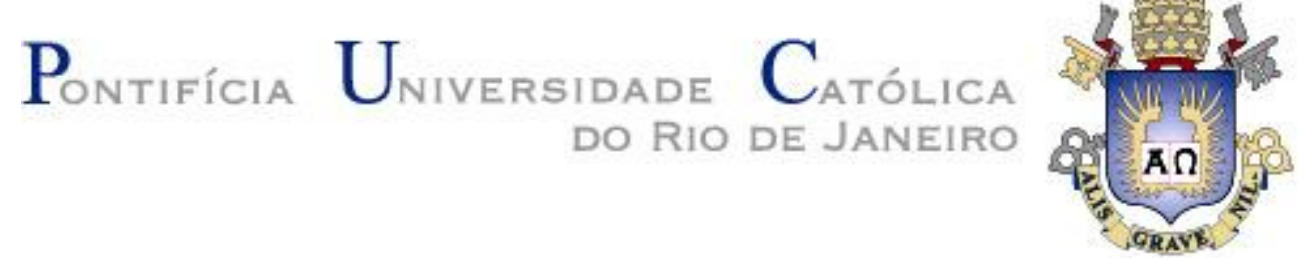

Jocelaine Terezinha Pereira Severo

\title{
DESENVOLVIMENTO HUMANO E ESPIRITUAL EM TERESA DE ÁVILA \\ Interfaces entre Mística, Psicologia e o Castelo Interior
}

\section{Tese de Doutorado}

Tese apresentada ao Programa de Pós-Graduação em Teologia, do Departamento de Teologia da PUCRio, do Centro de Teologia e Ciências Humanas $(\mathrm{CTCH})$, como parte dos requisitos para obtenção do título de Doutora em Teologia.

Orientadora:Profa. Lúcia Pedrosa de Pádua 


\title{
Pontifícia U Uiversidade C $_{\text {atólica }}$

\section{Jocelaine Terezinha Pereira Severo}

\begin{abstract}
Desenvolvimento humano e espiritual em Teresa de Ávila Interfaces entre mística, psicologia e o Castelo Interior.
\end{abstract}

Tese apresentada como requisito parcial para a obtenção do grau de doutora pelo Programa de Pós- Graduação em Teologia, Departamento de Teologia do Centro de Teologia e Ciências Humanas da PUC-Rio. Aprovada pela Comissão Examinadora abaixo assinada.

Profa. Lúcia Pedrosa de Pádua

Orientadora

Departamento de Teologia PUC-Rio

Prof. Alfredo Sampaio Costa Departamento de Teologia - PUC-Rio

Profa. .Vera Maria Ferrão Candau Departamento de Educação - PUC-Rio

Prof ${ }^{\mathrm{a}}$. Nilma Figueiredo de Almeida

Departamento de Psicologia - UFRJ

Prof ${ }^{\mathrm{a}}$. Karin Hellen Kepler Wondraceck Departamento de Teologia - EST

Profá. Denise Berruezo Portinari

Coordenadora Setorial de Pós-Graduação e Pesquisa do Centro de Teologia e Ciências Humanas - PUC-Rio

Rio de Janeiro, 27 de setembro de 2013. 
Todos os direitos reservados. É proibida a reprodução total ou parcial do trabalho sem autorização do autor, do orientador e da Universidade.

\section{Jocelaine Terezinha Pereira Severo}

Graduação em Psicologia (Universidade do Vale do Rio dos Sinos UNISINOS - 1995). Graduação em Teologia (Pontifícia Universidade Católica/RS - 2003). Mestrado em Teologia (Pontifícia Universidade Católica/RS - 2004). Doutorado em Teologia Pontifícia Universidade Católica/RJ - 2013). Experiência na área de Psicologia Clínica. Docência em Psicologia do Desenvolvimento, Teologia e Espiritualidade.

Severo, Jocelaine Terezinha Pereira

Desenvolvimento humano e espiritual em Teresa de Ávila: interfaces entre mística, psicologia e o Castelo Interior / Jocelaine Terezinha Pereira Severo ; Orientadora: Lúcia Pedrosa de Pádua. 2013.

300 p.; $30 \mathrm{~cm}$

Tese (doutorado) - Pontifícia Universidade Católica do Rio de Janeiro, Departamento de Teologia, 2013.

Inclui bibliografia

1. Teologia - Teses. 2. Auto-conhecimento. 3. Amor. 4. Castelo Interior. 5. Oração. 6. Teresa de Ávila. 7. Santa Teresa de Jesus. 8. Desenvolvimento humano e espiritual. 9. Mística. 10. Relacionamento com Deus. I. Pádua, Lúcia Pedrosa de. II. Pontifícia Universidade Católica do Rio de Janeiro. Departamento de Teologia. III. Título.

CDD: 200 
Dedico à minha mãe Francisca Severo

Com gratidão pela torcida, parceria no trajeto, palavras de conforto, de bênçãos e de fortaleza em cada momento. 


\section{Agradecimentos}

Agradeço a Deus o dom da vida e a oportunidade da realização deste doutorado.

À família pela meiga presença, principalmente nos tempos de maior dificuldade.

Agradeço à professora Lúcia Pedrosa de Pádua pela orientação recebida. Aos grupos inter-vinculados: Instituição Teresiana, Colégio Teresiano, de modo particular às diretoras Glória Fátima Nascimento e Angela Corrêa, Grupo Moradas, Orientandos de Graduação e de Pós, Grupo da Partilha do Livro da Vida, pelo incentivo.

Ao Professor Abimar Moraes, Coordenador da Pós-Graduação e Pesquisa da Teologia (PUC/RIO) e à sua equipe na secretaria. Aos estimados professores, diretores, coordenadores e professores do CTCH e CRE pelo apoio na continuidade dos estudos. À CAPES pela bolsa de estudos recebida, sem a qual a realização do doutorado não teria sido possível. Aos amigos e amigas das bibliotecas do Colégio Teresiano, Colégio Santo Inácio, da PUC/RIO, CECREI, UNISINOS, por todo apoio e disponibilidade.

Gratidão aos Padres Jesuítas do CECREI (São Leopoldo RS), da PUC/RIO, do Colégio Santo Inácio e do Centro Loyola/RJ. De modo particular ao Pe. Leopoldo Adami, ao Pe. Reitor da PUC/RJ, Pe. Josafá Carlos de Siqueira e aos padres: Jesus Hortal Sanchés, Pedro Magalhães Guimarães Ferreira, Paul Alexander Schweitzer, demais Sacerdotes e Irmãos da comunidade da Residência Leonel Franca pela orientação espiritual recebida e acompanhamento nas atividades realizadas.

À Sônia Rasuck, à analista Maria da Conceição da Silva Garcia das Neves, à Cristina Kirsch Bergonsi, à Rosana Lourenço da Silva, à Mônica Ballarin e família pelo alento e contribuição.

Às Congregações religiosas, especialmente à Irmã Guiomar Chemello, Irmãs de São José, Leigos do Pequeno Projeto, à Madre Teresinha e Irmãs Carmelitas, à Irmã Assunta Romio, Irmã Lucia Ignez Basotto, Irmã Isabel Morelló Culubret e Irmãs Teresianas pelos favores realizados e prece!

Aos fiéis colegas de trabalho no departamento da Teologia: Jane Maria Furghestti, Antônio Marcos dos Santos e Ednéa Martins Ornella por toda ajuda material e apoio recebido. 


\section{Resumo}

Severo, Jocelaine Terezinha Pereira; Pádua, Lúcia Pedrosa de, (Orientadora). Desenvolvimento humano e espiritual em Teresa de Ávila Interfaces entre mística, psicologia e o Castelo Interior. Rio de Janeiro, 2013. 300 p. Tese de Doutorado - Departamento de Teologia, Pontifícia Universidade Católica do Rio de Janeiro.

O presente trabalho defende a tese de que, nas distintas Moradas da Obra do Castelo Interior de Teresa, é possível visualizar e nominar fases do desenvolvimento humano e espiritual (diferentes graus de amor), nas quais a pessoa se encontra. Mostra a mística teresiana como alternativa para se compreender o amor de Deus e a espontânea resposta a essa gratuidade divina, experenciada e vivida, pela pessoa, na fé e na sua intensidade. As fases de desenvolvimento humano e espiritual assinalam o desabrochar da maturidade no amor que se plenifica na transcendência de si, na entrega dedicada ao serviço dos irmãos e irmãs e à sociedade em geral, gerando conversão e transformação da mesma, anúncio e continuidade dos valores propostos por Jesus Cristo.

\section{Palavras-chave}

Auto-conhecimento; Amor; Inter-relação; Castelo Interior; Oração; Teresa de Ávila; Santa Teresa de Jesus; Desenvolvimento humano e espiritual; Mística; Psicologia; Relacionamento com Deus; Fases do desenvolvimento humano e espiritual. 


\section{Abstract}

Severo, Jocelaine Terezinha Pereira; Pádua, Lúcia Pedrosa de (Advisor). Development human and spiritual in Teresa of Avila Interfaces between mysticism, psychology and Interior Castle. Rio de Janeiro, 2013. 300 p. Doctoral Thesis - Departamento de Teologia, Pontifícia Universidade Católica do Rio de Janeiro.

The present work defends the thesis that the different "moradas" of the book of the Interior Castle of Teresa of Ávila, can visualize different phases of development human and spiritual (or different degrees of love), in which a person finds himself. And at the same time, these phases can be nominated. The thesis proposes a Teresian mystic as an alternative for understanding the love of God by the person and the consequent response to this love, experienced and lived in its intensity. The development of the phases marks the way to maturity in love that deepens the transcendence of self in service to our brothers and sisters, to society in general, generating conversion and transformation of it, the announcement and the continuity of the values proposed by Jesus Christ.

\section{Keywords}

Self-knowledge, love; interrelation; Interior Castle; Prayer; Teresa of Avila; St. Teresa of Jesus; Human Development; Mysticism; Psychology; Psychoanalysis; Relationship with God; Relationship with siblings; development stages. 


\section{Sumário}

INTRODUÇÃO GERAL

1 QUINHENTOS ANOS DO NASCIMENTO DE TERESA DE ÁVILA 18

1.1 Introdução 18

1.2 Celebrar a vida, acolhendo o dom de Si Mesmo de Deus 23

1.2.1 Contexto histórico da vida de Teresa 23

1.2.2 Nascer para uma Vida de Relações 28

1.2.3 Nascer para Deus: Vossa sou, para vós nasci 31

1.2.4 Nascer para os irmãos 33

1.2.5 Nascer mulher $\quad 36$

1.3 Celebrar a vida em relação, fecunda e permanente $\quad 40$

1.3.1 Reconhecimento da mística, vida e obra de Teresa 40

1.3.2 Fé e ousadia permanecem na história 42

1.3.3 Uma mulher para o tempo atual 43

1.4 Conclusão 45

2 A MÍSTICA CRISTÃ $\quad 47$

2.1 Introdução $\quad 47$

2.2 Conceitualizações $\quad 47$

2.2.1 Conceito de Mística Cristã 47

2.2.2 Expressões relacionadas à mística 53

2.2.3 Mística cristã e fenômenos místicos 60

2.2.4 Fenômenos extraordinários e psicológicos 63

2.2.5 A mística teresiana $\quad 70$

2.3 Problematização da relação entre ciência e mística 73

2.3.1 Relação entre ciência e mística ao longo da história 73

2.3.2 Ciência e mística na atualidade $\quad 80$

2.4 Conclusão $\quad 85$

3 TERESA, MÍSTICA E PSICOLOGIA 87

3.1 Introdução $\quad 87$

3.2 Uso de algumas expressões e abordagens psicológicas $\quad 87$

3.3 Premissas da psicologia para um olhar sobre a mística $\quad 95$ 


\section{OLHAR DA CIÊNCIA E DA PSICOLOGIA SOBRE A MÍSTICA DE} TERESA

4.1 Introdução

4.2 A Mística de Teresa vista pela ciência e pela psicologia em seus primórdios

4.2.1 Ponto de partida (Pe. Hahn, no terceiro Centenário da morte de Teresa)

4.2.2 Teresa à contraluz na ciência e na psicologia nascente 140

4.3 A Mística de Teresa vista por alguns olhares da Psicologia Atual

4.3.1 Teresa e a Psicanálise Lacaniana 166

\section{MÍSTICA TERESIANA E A OBRA DO CASTELO INTERIOR 182}

5.1 Introdução

5.2 Relação com Deus e com os irmãos: preâmbulos à mística teresiana

5.2.1 Impulso a partir do relacionamento e da amizade de Deus

5.2.2 Impulso como resposta humana à iniciativa de amor de Deus

5.3. A obra de Teresa que se reescreve na atualidade

5.3.1 Influência literária presente na redação do Castelo

5.3.2 Castelo Interior e seus símbolos (ao redor e interior)

5.3.3 Castelo Interior e seus defensores

5.3.4 Castelo Interior e seus inimigos

5.4 Características das Moradas do Castelo Interior 206

5.4.1 As Primeiras Moradas do Castelo Interior 206

5.4.2 As segundas moradas do Castelo Interior 208 
5.4.4 As Quartas Moradas do Castelo Interior 214

5.4.5 As Quintas Moradas do Castelo Interior 217

5.4.6 As Sextas Moradas do Castelo Interior 222

5.4.7 As Sétimas Moradas do Castelo Interior 227

5.5 Conclusão 232

\section{DESENVOLVIMENTO HUMANO E ESPIRITUAL A PARTIR DO} CASTELO INTERIOR

6.1 Introdução 235

6.2 O amor em seus diferentes níveis 236

6.3 O amor na vida e perspectiva de Teresa 242

6.4 Fases do desenvolvimento no Castelo Interior 245

6.4.1 Fase da inconsciência 245

6.4.2 Fase da inconsistência 250

6.4.3 Fase da transcendência 258

6.4.4 Fase da benevolência 261

6.4.5 Fase da transparência 264

6.4.6 Fase da resplandecência 266

6.4.7 Fase da florescência 268

6.5 Conclusão 273

CONCLUSÃO GERAL 276

REFERÊNCIAS BIBLIOGRÁFICAS 282 


\section{ABREVIATURAS DAS OBRAS DE SANTA TERESA}

Embora a autora da tese tenha optado pela edição espanhola, para os estudos pessoais, a redação deste trabalho tem por base o texto da edição brasileira estabelecida a partir das Obras Completas de Santa Teresa de Jesus, revisado e anotado por Frei Tomás de La Cruz, O.C.D. São Paulo: Loyola, 1995. As cartas seguem o texto original, segundo a edição crítica de Frei Silvério de Santa Teresa. Direção: Pe. Gabriel C. Galache, S. J.; Coordenação Frei Patrício Sciadini, O.C.D. Tradução: Adail Ubirajara Sobral, Maria Stela Gonçalves, Marcos Marcionilo, Madre Maria José de Jesus.

$$
\begin{array}{ll}
\text { C } & \text { - Caminho de Perfeição } \\
\text { CAD } & \text { - Conceitos do Amor de Deus } \\
\text { Cta. } & \text { - Cartas } \\
\text { F } & \text { - Fundações } \\
\text { M } & \text { - Castelo Interior (ou Moradas) } \\
\text { P } & \text { - Poesia } \\
\text { R } & \text { - Relações } \\
\text { V } & \text { - Livro da Vida }
\end{array}
$$

Nas obras de Teresa, a letra indica a obra, o primeiro número, o capítulo e os seguintes números referem-se às subdivisões dentro do capítulo. No caso da obra mais utilizada nesta tese: Castelo Interior o Moradas, o número que antecede a abreviatura da obra indica a qual das sete Moradas o texto está se referindo. Ex. 3M. Leia-se terceiras moradas. Em prólogos e epílogos utiliza-se a abreviação correspondente: Prol. e Epíl. 


\section{ABREVIATURAS GERAIS}

\section{BÍBLICAS}

AT

Ct - Cânticos

Eclo - Eclesiástico

Ex - Êxodo

Gn - Gênesis

$\mathrm{Hb}$ - Hebreus

Is - Isaías

S1 - Salmo

NT
Mt - Mateus
Mc - Marcos
Lc - Lucas
Jo - João
At - Atos dos Apóstolos
1Cor - Primeira Epístola aos Corintios
Ef - Epístola aos Efésios
Gl - Epístola aos Gálatas
1Jo - Primeira Epístola de São João
$\mathrm{Rm}$ - Epístola aos Romanos
Tg - Epístola de São Tiago
Tt - Epístola a Tito

\section{DIVERSAS}

Pe. Padre

n. número(s)

p. página(s) 


\section{BÍBLIA, DOCUMENTOS DA IGREJA E OUTROS RELACIONADOS}

TEB Tradução Ecumênica da Bíblia

LG Constituição Dogmática Lumen Gentium

DV Constituição Dogmática Dei Verbum - Concílio Vaticano II

GS Constituição Pastoral Gaudium Et Spes - Concílio Vaticano II

CEC Catecismo da Igreja Católica

CIC Código de Direito Cânônico

\section{TERESIANAS}

ABC Archivum Bibliographicum Carmelitanum

BMC Coleção Biblioteca Mística Carmelitana

EDE Editorial de Espiritualidade 
Nada te perturbe

Nada te espante

Tudo passa

Só Deus não muda

A paciência tudo alcança

Quem a Deus tem

Nada lhe falta

Só Deus basta

Teresa de Ávila.

Eficácia da Paciência

Poesia IX adaptada das Obras Completas. 


\section{INTRODUÇÃO GERAL}

A presente tese propõe-se a descrever, analisar, interpretar e inter-relacionar as diferentes moradas do Castelo Interior de Teresa identificando, nas mesmas, distintas fases do desenvolvimento humano e espiritual. Nomina-as e as especifica. Para dar-lhes nome, lança mão do referencial da teologia em interface com a psicologia, acolhendo a contribuição de seus diferentes autores.

Para chegar à finalidade última tem um percurso específico, desde situar a autora da obra Castelo Interior, em seu contexto de realidade, até a descrição propriamente dita das devidas fases de desenvolvimento. A obra de Teresa de Ávila é, aqui, também contextualizada. Opta-se, ainda, pela descrição detalhada, entre todas, da obra do Castelo Interior, dado servir esta como obra fundamental para o trabalho em questão.

A tese segue com a reflexão de como a mística e a ciência foram se entendendo ao longo da história. Suas aproximações, distanciamentos, arestas e ajustes. Demonstra alguns limites da ciência e da mística, a necessidade que uma tem da outra, o racionalismo como um período importante para o desenvolvimento da humanidade. Evidencia que própria razão não deu conta de tudo explicar ao humano. Mostra a mística como alternativa de busca de outras respostas, ou a algo que aponta para aquilo que está para além do que se pode ver. Depois, aborda o suposto olhar da psicologia sobre Teresa. A nova ciência que desponta com as novas descobertas desde Charcot sobre a "histeria", "alucinações". Baseando-se nesse neurologista, a psicologia abraça seu percurso inicial e dá seguimento às suas pesquisas. Freud tem seu posicionamento em relação à religiosidade. Muitos psicólogos e psicanalistas, posteriores, tentam decifrar Teresa e enquadrá-la em diagnósticos. A ciência da psicologia, com o tempo, avança e se renova em suas orientações e em seus especialistas. Hoje, algumas linhas da psicologia, sobretudo, a lacaniana e a junguiana, buscam compreender melhor o pensamento, a mística e a própria vida de Teresa.

Não se tem, nessa tese, o objetivo de analisar os posicionamentos e enquadramento das diferentes linhas e especialistas da psicologia que falam a respeito de Teresa, apenas tem a finalidade de constatar alguns dos caminhos, por onde Teresa, sua obra e imagem foram passando. Não se tem também, aqui, a pretensão de dar conta e continuidade das reflexões psicológicas iniciadas. A obra 
é definidamente uma tese teológica, serve-se do aporte da psicologia colocando-se em sua interface apenas com o intuito de melhor dar a conhecer e compreender a mística teresiana, naquilo que explicitamente se propõe em seus objetivos.

Depois, a redação dessa pesquisa orienta-se em direção à mística de Teresa. Aproxima-se, assim, mais apropriadamente da obra da autora em questão: Castelo Interior ou Moradas, tendo a finalidade de verificar o que lhe é especifico, qual a simbologia usada, como Teresa mesma vai mostrando o desenvolvimento humano e espiritual nas diferentes moradas para adentrar-se, ainda mais, na vida mística.

Por último, defende a hipótese já mencionada de que: em Teresa é possível identificar as diferentes fases de desenvolvimento humano e espiritual, que podem ser nominadas e caracterizadas. À hipótese levantada correspondem as seguintes fases do desenvolvimento humano e espiritual:

Primeiras Moradas - $\quad$ Fase da inconsciência

Segundas Moradas - $\quad$ Fase da inconsistência

Terceiras Moradas - $\quad$ Fase da transcendência

Quartas Moradas - $\quad$ Fase da benevolência

Quintas Moradas - $\quad$ Fase da transparência

Sextas Moradas Fase da resplandecência

Sétimas Moradas - $\quad$ Fase da florescência

A tese se justifica, sobretudo, em função da sede pela mística no atual tempo da pós-modernidade, como também mostra sua relevância, particularmente, por colocar o tema da mística teresiana na interface de duas ciências: teologia e psicologia, movimento interdisciplinar tão importante para o momento científico atual.

Para Teresa, a vida centrada em Cristo é uma proposta, um caminho para o humano transcender-se, adentrar ao próprio castelo e chegar bem mais proximo à "fonte da vida". Dessa fonte "jorra água viva" para o conhecimento pessoal e interpessoal, para a integração da personalidade e das relações interpessoais. A "água" da qual Teresa bebe e oferece aos irmãos e irmãs renova o sentido existencial e transforma a vida, verdadeiramente.

A pesquisa contempla seis capítulos de desenvolvimento, acrescida de conclusão e referências bibliográficas. A abordagem destes está direta e 
sequencialmente relacionada aos objetivos almejados, servindo-se do método dedutivo-analítico. Os capítulos encontram-se na seguinte sequência:

O capítulo 1 - Dá a conhecer a vida e a obra da monja em questão, com um tom de fundo celebrativo, dado a situar-se esta tese, dentro do marco das Celebrações do V Centenário do nascimento de Teresa de Ávila (1515-2015). Mostra ainda o reconhecimento da Igreja e da sociedade por sua contribuição, presença feminina e mística na história.

O capítulo 2 - Aborda o conceito de mística, expressões relacionadas à mística, a mística e seus fenômenos, os fenômenos místicos extraordinários, os fenômenos psicológicos, a diferenciação entre eles, a conceituação e o entendimento da mística teresiana e, ainda, a problematização da relação ciência e mística na história e no momento atual.

O capítulo 3 - Dá a entender o uso de expressões e abordagens psicanalíticas, mostra premissas da psicologia para um olhar sobre a mística em geral e sobre a mística teresiana e situa o desenvolvimento da mística na modernidade.

O capítulo 4 - Leva o leitor ao ponto de partida de onde Teresa foi colocada sob o olhar da ciência e desenvolve a temática de como Teresa esteve à contraluz da ciência da psicologia em seus primórdios. Mostra como os aspectos de sua doutrina mística da santa e seus escritos foram reconhecidos e valorizados por algumas linhas da psicologia.

O capítulo 5 - Procura compreender dados específicos da mística teresiana, traz chaves para a leitura dos símbolos usados pela monja, evidencia como se dá o desenvolvimento humano e espiritual e o relacionamento com Deus e com os irmãos, na obra do Castelo Interior de Teresa de Ávila.

O capítulo 6 - Serve-se dos aportes da teologia e psicologia para definir, interpretar, caracterizar e nomear as diferentes fases do desenvolvimento humano e espiritual da mística teresiana.

Por intermédio da metodologia usada, da pesquisa bibliográfica realizada e da análise dos dados, espera-se contribuir para o desenvolvimento do conhecimento teórico, no que diz respeito à compreensão teológica das fases de desenvolvimento e de maturação humana espiritual. 


\section{QUINHENTOS ANOS DO NASCIMENTO DE TERESA DE ÁVILA}

\section{1 Introdução}

A Igreja, ordens e congregações religiosas, teólogos(as), leigos(as), amantes da literatura, das artes e da mística, num número incontável de admiradores de Teresa de Ávila preparam-se para celebrar os quinhentos anos do nascimento de uma monja que marcou a narrativa de seu tempo e a vocação de tantos ao longo da história. Vê-se, neste sentido, em plena virada do milênio e para além da Espanha, poemas, quadros, músicas, esculturas, mídias e obras suas, ou que falam a seu respeito, vendidas com relativa facilidade. É a vida, é a obra, é o carisma teresiano em movimento! Com focos nesta linha, bibliotecas esparsas pelo mundo inteiro, renovam seus acervos. Círculos de leitura crescem. Grupos de oração e de espiritualidade se fortalecem e se unem para escutar, interpretar e saborear os escritos de Teresa de Ávila, acrescendo às próprias experiências de vida, as da vida desta mística do século XVI, com o intuito de, a partir de sua mensagem, alavancar, re-significar e transformar suas existencialidades.

Assim, com suportes desta natureza, boa parcela da enorme multidão vai dando atenção peculiar à insaciável sede de Deus, alimentando suas performances humanas e espirituais. Para o olhar atento à monja que extrapola o tão famoso século de ouro, a evidência desse comportamento social suscita um suave, mas intenso questionamento: por que tudo isso?! Por que está tão viva e presente Teresa também na pós-modernidade?! Por que crer tão firmemente que, ainda hoje, esta mulher tenha um recado a dar à humanidade e continua a influenciar a vida de inúmeras pessoas na Igreja e na sociedade atual?! Que há em Teresa que a faz permanecer tanto tempo por aqui?!

Com certeza, a compreensão da sua vida, sua obra, sua influência, ao longo de toda uma trajetória e, talvez também, de alguma forma, o desenvolvimento desta tese poderão evidenciar com maior clareza o ensejo de resposta a alguns questionamentos. Contudo, à guisa de introdução, o pensamento de duas grandes personalidades dentro do universo teológico oferece um ponto de partida que não 
somente corrobora na delineação do tema, como se faz coluna dorsal, uma vez que as frases em destaque, tal como pano de fundo, podem sustentar tudo o mais que se expressará, aqui, a respeito de Teresa.

Neste sentido o primeiro aspecto que se propõe é o posicionamento do teólogo Hans Küng, um dos pensadores de maior influência na Teologia atual que reflete e enfatiza o protagonismo e a dignidade feminina à luz da posição radicalmente mudada das mulheres na sociedade hodierna ${ }^{1}$. Com isso, Küng acena para a mulher que ao ter-se em suas próprias mãos consegue beber em seu próprio poço e emergir em profunda consciência de sua realidade pessoal, amplamente convicta da razão de seu existir. Movida por sua identidade e dignidade, a mulher que protagoniza a vida, com a fortaleza da fé de quem crê ser possível a concretização de um mundo melhor, vê-se inserida em uma realidade concreta, em uma sociedade personalizada por suas características específicas, na qual será capaz de lutar pela vida e pelos direitos de seus semelhantes, não se admitindo em um lugar de assujeitamento. Ao contrário, ao situar-se em sua realidade e, desde a perspectiva de sua esperança, alicerçada na alavanca de motivação de seus sonhos e desejos, coloca-se em movimento, na busca da conquista de espaços melhores e mais adequados à progressão da vida. Por esta razão, faz a história acontecer!

$\mathrm{O}$ segundo aspecto que se coloca como fio condutor para o desenvolvimento deste trabalho é a posição de Karl Ranher, um dos maiores teólogos do século XX, com sua célebre frase que se torna quase uma máxima: "o cristão do século XXI ou será um místico, ou não será nada. Não será cristão"2! Deste modo o teólogo alude à fonte do Mistério, de onde jorra a vida e a graça, para o qual ser humano está chamado. Ou será místico, ou não será cristão. Aqui o ser místico pode ser traduzido como sinônimo daquele que alcança a fonte indo verdadeiramente ao encontro da Vida, sem permitir que a existência acabe-se na sua superficialidade, na casca, sem a possibilidade de adentrar-se ao mistério de si mesmo, de Deus, da humanidade. Ambos os teólogos a partir dessas referências oferecem elementos interessantes que ajudam a inicialização e o percurso da

\footnotetext{
1 "Só agora, na era da democracia e da igualdade de direitos, elas conseguiram ser admitidas a todos os postos[...]. KUNG, H. Por que ainda ser cristão hoje? Campinas: Versus, 2004. p. 105.

2 RAHNER, K. Elementos de espiritualidad en la iglesia del futuro. Apud GOFFI, T.; SECONDIN, B.; Problemas y perspectivas de espiritualidad. Salamanca: Sígueme, 1969. p. 469.
} 
temática sobre o significado da postura, existência, oração e ação desta santa do século XVI.

A sociedade na qual se situa Teresa é repressora, está pouco aberta à democracia. Nela a mulher encarrega-se praticamente do cuidado do lar, consumindo sua vida no exercício de ajustar-se a um lugar de escondimento e assujeitamento ao homem e às autoridades. Nesta sociedade ela frequentemente tolhida, agredida, ou oprimida, encontra-se basicamente sem direito a vez e à voz.

Embora de sexo feminino, de descendência não cristã, religiosa e, ainda não obstante, monja carmelita, num século onde o normal era considerar-se a mulher num segundo plano, Teresa não se visualiza e nem permanece nessa condição de refém, de subalterna, como a época e a sociedade procuravam determinar à mulher. Se é possível analisar o viés da sucessão das categorias de exclusão de sua própria história, teria tudo para viver no ocultamento, no silêncio e ver sua vida passar na mais completa obscuridade. Contudo, com suas palavras, com seu coração e com sua ação inverte o processo, mostrando com o existir a dignidade, a graciosidade, a fecundidade e a vitalidade de tudo que seu papel feminino comporta. Desta forma é que esta histórica mulher protagonizará a vida e a colocará a serviço visando à transformação da sociedade de seu tempo e de novos tempos, desde uma mudança interior a partir de si mesma, desde sua interioridade.

E, não será este seu segredo?! Que além de mulher verdadeiramente assumida, enquanto tal, Teresa também seja mística ${ }^{3}$ ?! Não será justamente a força motriz intrínseca ao misticismo, engendrada a partir de uma profunda e autêntica vivência de um processo contínuo de internalização e de inter-relação com o transcendente e com os irmãos, o que traz a fortaleza para Teresa ser o que é e realizar o que faz com tanta propriedade, ardor e com tanto profetismo?!

Essa mística de Teresa, reconhecida e autenticada pela fé da Igreja apresenta-se como uma mística real, com sua linguagem própria, profundamente cristológica $^{4}$. Sua vivência espiritual mostra o quanto, de fato, ela prova do amor

\footnotetext{
${ }^{3}$ Os místicos consideram a experiência de relacionamento com Deus um diálogo com o Outro e a "A mística cristã conhece e vivencia o "você" de Deus[...] e inclui toda a eternidade[...]". SUDBRAK, J. Mística: a busca do sentido e a experiência do absoluto. São Paulo: Loyola, 2007. p. 41.

${ }^{4}$ A mística de Teresa é uma mística cristológica, o tema da humanidade de Cristo sempre está presente em sua vida e em sua obra. Assim "Santa Teresa há devuelto la mística a lo más Cristiano y situado la figura de Jesús como el único centro real de la experiência de Dios". TORRES
} 
de um Deus que a ama profundamente, de um Deus que faz história com ela e com seu povo. A intensa interiorização de seu orar, narrada em sua obra, acompanhada da historicidade, passo a passo com Cristo, revela como a mística leva Teresa acolher a vida da graça, fazendo-a saborear deste Deus que vem ao encontro da pessoa humana na sua realidade mais específica e que se dá, gratuitamente, em pleno amor para todos. Isso porque, de fato, o Deus que se revela em Cristo, no evangelho e na vida de Teresa está Vivo e a faz sinalizar esta verdade: que Ele é um Deus para todos, que ama a todos indistintamente, que está presente e caminha com seu povo, em todos os momentos da trajetória humana ${ }^{5}$.

Ao se vivenciar e ao acolher a experiência e a verdade desse amor no mais íntimo de si mesmo(a), ao mergulhar-se na profundidade do interior, sente-se a necessidade de se fazer o mesmo movimento ensinado pela monja: de sair de si e de voltar-se aos demais. Por isso, Teresa vibra, comunica, toca os corações humanos e ajuda a humanidade favorecendo com que muitos também elejam e acolham a esse Deus e à sua graça e deixem-se transformar por ela. Viver esta mística, na gratidão e na gratuidade do que o Senhor oferece, é viver o que Rahner diz: acolhendo na auto-comunicação de Deus, a graça do próprio dom de Si Mesmo! E, justamente nesse sentido, é que o

Dom pessoal de si mesmo de Deus significa, antes de tudo, que o comunicado é realmente Deus mesmo em seu próprio ser. Não se trata de um mero falar sobre Deus, tampouco de uma comunicação puramente objetiva, pensada à maneira de uma coisa, nem uma participação de si à criatura, doando realidades criadas e finitas. Deus se dá verdadeiramente e no sentido mais rigoroso da palavra, a si mesmo. O doador é em si mesmo o dom 6 .

Desta forma, percebe-se que essa mística autêntica, que acolhe a graça como o dom de Si mesmo de Deus, na qual Teresa mergulha e dela emerge como mestra a orientar o caminho a muitos, como tão bem se pode observar em sua vida, nada

SÁNCHEZ, S. Mística y cristología en Santa Teresa. In: CASTRO, S. (Org.). Teresa de Jesús. Presencia Permanente. Revista de Espiritualidad. n. 222-223. ene/jun. Madrid, 1997. p. 80.

${ }^{5}$ As obras de referência de Santa Teresa, nesta tese serão citadas em notas de rodapé. SANTA TERESA DE JESUS. Livro da Vida. In: SANTA TERESA DE JESUS. Obras Completas. Revisada e anotada por Frei Tomás de La Cruz. Coordenação Frei Patrício Sciadini. 2. ed. São Paulo: Loyola, 2002. (Abreviada por V). V 39,9; SANTA TERESA DE JESUS. Caminho de Perfeição. In: SANTA TERESA DE JESUS. Obras Completas... (abreviada por C). C 37,3; SANTA TERESA DE JESUS. Castelo Interior ou Moradas. In: SANTA TERESA DE JESUS. Obras Completas... (abreviada por M). 1M 1,3 e 5M4,10.

${ }^{6}$ SCHICKENDANTZ, C. F. Karl Rahner: Una fuente de inspiración. Projeto. v. 42. Documento de Trabalho. Córdoba: Universidad Catolica Secretaría de Investigación y Posgrado, 2002. pp. 1821. (Filosofía y humanidades). Observação: todas as inferências da autora da tese, nesta publicação, tem suas citações colocadas em colchetes, as demais são próprias do autor citado. 
tem a ver com sentimentalismos baratos, emoções supérfluas esvaziadas de sentido, ou sucetíveis de aprisionamento a uma irracionalidade e subjetividade alienantes e/ou paralisantes para o ser humano. Ao contrário, é a mística daquele que coloca os pés no chão de sua contemporaneidade e a compreende, existencialmente, como um tempo privilegiado para experienciar o amor de Deus, no mesmo momento em que vê também que é tempo de agir e de amar. É a mística daquele que olha o mundo numa perspectiva futura como passível de ser modificado, já no hoje, para melhor, por isso é capaz de comprometer-se e envolver-se no clamor por justiça e dignidade para todos.

Neste sentido, o místico, o que assimila a dádiva deste Deus que se encarna e se dá a Si mesmo, faz do encontro com a Vida, fortaleza para seu agir. Só assim, é possível viver a unidade dos ramos com a videira, neste amor que se faz ação: ouvindo com o coração e afinando os sentidos em direção ao eco da realidade, decidindo-se a ir ao encontro do irmão e da irmã, nas pegadas do Mestre Jesus ${ }^{7}$.

Deste modo, a celebração dos quinhentos anos do nascimento de Teresa, este tempo festivo no qual, com maior ênfase se rememora uma mulher que acolhe o dom de Si Mesmo de Deus e com sua vivência dá uma interpretação encarnada e personalizada ao cristianismo, lembra ao mundo atual que é possível, a todos e a todas, mudar com originalidade a realidade de seu tempo, por isso,

celebrar Teresa é redescobrir também rumos da mística no nosso tempo, em que há tantos buscadores de Deus, muitas vezes perdidos em mil caminhos. A mística pode ser comparada a um canto de pássaro no meio da ruidosa cidade. Apenas pode ser ouvido quando se faz silêncio. Em tempos de mudanças e quebras de paradigmas, como são os nossos tempos, este silêncio se impõe, não raro em meio a perplexidades. O desejo de Deus pulsa mais forte buscando sentido em meio às realidades fragmentadas. No entanto, o discernimento não é tão simples[...].A vida nova nos diz que algo é preciso deixar, para voltar a ver e viver na profundidade do que é essencial ${ }^{8}$.

Para melhor compreensão da vida de Teresa, no ponto 1.2 trabalha-se o contexto de sua realidade histórica, como se fortalece sua vocação e missão. E no ponto 1.3, como sua vida, mística e obra são percebidas pela Igreja, qual a importância da sua história, da sua ação e da sua feminilidade ao longo dos seus 500 anos de nascimento e para os dias atuais.

\footnotetext{
${ }^{7}$ Cf. Jo $15,1-8$.

8 PEDROSA-PADUA, L. Apresentação. In: PEDROSA-PÁDUA, L.; CAMPOS, M. (Orgs.). Santa Teresa: Mística para o nosso tempo. São Paulo/ Rio de Janeiro: Reflexão/PUC-Rio, 2011. p. 7-8.
} 


\section{2 \\ Celebrar a vida, acolhendo o dom de Si mesmo de Deus}

Este ítem detalha melhor o contexto histórico, o significado da vida de Teresa, como entendê-la, enquanto: mulher de relações, na sua doação completa da existência à Deus, aos irmãos e irmãs, na sua coragem para o enfrentamento dos desafios, contribuição para Igreja, para a sociedade e permanência na história.

\subsection{1}

\section{Contexto histórico da vida de Teresa}

Este ponto da tese situa a pesquisa num contexto histórico, sócio-eclesial, analisando a Teresa de Ávila dentro dos limites de um período que mostra sua vida e obra revestidas da roupagem, da influência e das características específicas de sua época que, contudo, a ultrapassa9. Mostra o valor da mulher Teresa, cujo centenário de nascimento celebra-se em 2015 e dá razões para se compreender como a mística segue viva, exuberante, tornando-se essa referência de vida a tantas pessoas de outros tempos, particularmente, hoje, à mulher pós-moderna.

A época do nascimento de Teresa abria-se ao século de ouro, no qual a Espanha "atingia o zênite do seu poderio terrestre"10, com extensão de terras presente nos cinco continentes ${ }^{11}$. Descobertas ultramarinas apareciam como a novidade do momento; exploração e capitalização de riquezas mudavam a efervescência de sonhos em neófitas realidades, com sucessivas e novas experimentações de progresso em todas as áreas. Tudo isso definia um novo tempo, pois este era o:

\footnotetext{
${ }^{9}$ Para maiores esclarecimentos a respeito do contexto histórico, social e eclesial de Teresa, sugerese as seguintes leituras: PFANDL, L. Cultura y costumbres del pueblo espanõl de los siglos XVI e XVII: Introducción al estudio del siglo de oro. Barcelona, 1959; STEGGINK, O.; EFREN DE LA MADRE DE DIOS. Tiempo y vida de Santa Teresa. 2. ed. Madrid: BAC, 1977; MONTALVA, E.; BARRIENTOS, A. Introducción a la lectura de Santa Teresa. Madrid: Editorial de Espiritualidad, 1978; CASTANHEIRA AVELAR, M. C; RUBIO, A. G. Experiência mística e comunicação teológica: estudo sobre o estilo pedagógico da Teologia de Teresa de Jesus, na "Vida", no "Caminho" e no "Castelo Interior". 2 v. Tese (Doutorado) - Rio de Janeiro: Pontifícia Universidade Católica do Rio de Janeiro, Departamento de Teologia, 1998; PEDROSA-PADUA, L. O Mistério de Deus em Santa Teresa: Experiência do mistério trinitário na obra de Teresa de Jesus. 2 v. Tese (Doutorado). Pontifícia Universidade Católica do Rio de Janeiro, Departamento de Teologia, 2001.

${ }^{10}$ AUCLAIR, M. Teresa de Ávila: a dama errante de Deus. São Paulo: Quadrante, 1995. p. 40.

${ }^{11}$ Cf. BURGO, L; NAVARRO, E. G.; GUERRA, A. Para leer a Santa Teresa. Santo Domingo: Monte Carmelo/Editorial de Espiritualidad del Caribe, 1994. p. 25.
} 
Século da inserção da Espanha unificada na Europa, de sua expansão através da conquista da América - às Índias - de guerras vencidas e manifestações culturais extraordinárias, especialmente de caráter filosófico e literário. Poder político e econômico[...] como toda realidade é um século de luzes e sombras ${ }^{12}$.

Às luzes e sombras deste período acrescenta-se que nesse país, onde "não se é verdadeiramente espanhol se não se é católico"13 , pelejava-se contra a invasão árabe, há oitocentos $\operatorname{anos}^{14}$. Ali cristãos, mouros e judeus conviviam ora pacificamente, ora em conflitos e perseguições ${ }^{15}$. E, não obstante a luta do povo entre si, a força maior do Estado os obrigava, todos, a converterem-se ao catolicismo. Diante desta imposição abrolhou-se a dita limpeza de sangue, um procedimento que consistia em provar que os ancestrais na família não eram mouros, tampouco judeus ${ }^{16}$. Com isto, os novos cristãos sofriam forte estigmatização social e penoso preconceito. Eram chamados de "cristãos novos, mas para o povo eram marrons, pois não tinham sangue limpo, em contraposição aos cristãos antigos" ${ }^{\text {17 }}$. Inclusive a própria família de Teresa sofre esta exclusão e discriminação. E a Igreja, talvez para não sentir-se mal interpretada, ou discriminada, opta por uma postura de maior sigilo diante destas questões. Autores teresianistas também embarcam neste silêncio, preferindo reforçar a origem de nobreza da mística a incluí-la entre os excluídos. Resultado: longo tempo na história para elucidar e elaborar o que hoje vê- se com maior clareza:

O "descobrimento" da origem judaica pelo ramo paterno de Teresa foi dado somente em 1946, pelo fato de terem sido achados[...] documentos que comprovavam que seu pai, seus tios e seu avô paterno eram judeus; até então só existiam silêncios na documentação, inclusive na autobiografia de Teresa, onde nenhuma menção direta à sua situação social é escrita. No entanto, segundo Teófanes Egido, a própria Teresa sinaliza para esta sua origem de forma indireta: não existe em "Libro de la Vida" alusão alguma à fidalguia do pai; mas ocorre a simples indicação por parte da escritora sobre a afeição de seu pai aos livros, aos estudos e à alfabetização de todos os seus filhos, tanto homens quanto mulheres, o que era muito comum entre os judeus da época ${ }^{18}$.

\footnotetext{
12 PEDROSA-PADUA, L. Vida e Significado de Santa Teresa de Jesus. In: PEDROSA-PADUA, L.; CAMPOS, M. (Orgs.). Santa Teresa... p. 25.

${ }^{13}$ BURGO, L.; NAVARRO, E; GUERRA, A. Para leer... p. 34.

${ }^{14}$ Cf. REYNAUD, Elisabeth. Teresa de Ávila ou o Divino prazer. 2. ed. Rio de Janeiro/São Paulo: Record, 2001.p. 20.

${ }^{15}$ Cf. BURGO, L.; NAVARRO, E; GUERRA, A. Para leer... p. 26.

${ }^{16}$ Cf. AUCLAIR, M. Teresa de Ávila... p. 29.

${ }^{17}$ BURGO, L.; NAVARRO, E; GUERRA, A. Para leer... p. 27.

${ }^{18}$ SANTOS, L. L. Fémina Inquieta y Andariega: Valores e Símbolos da literatura cavaleiresca nos escritos de Santa Teresa de Jesús (15-15-1582). Dissertação (Mestrado) - Porto Alegre: Universidade Federal do RS, Instituto de Filosofia e Ciências Humanas, 2006. p. 46.
} 
Esta constatação, num primeiro momento, dá um entendimento distinto aos estudos teresianos provocando impactante surpresa à Igreja da época, uma vez que a santa não descende de origens cristãs, mas por sua ancestralidade pertence ao grupo dos marginalizados, dos duramente punidos e excluídos pela severidade dos estatutos de limpeza. Nota-se, com isso, que Teresa também é vítima do preconceito e precisa mover-se dentro da condição social e dos limites que a sociedade de seu tempo lhe impõe ${ }^{19}$.

Do ponto de vista eclesial, outra enorme rigidez manifestava-se, sobretudo na Inquisição e no Index, órgãos encarregados da pureza da doutrina e dos costumes. Estavam eles objetivados a manter a ordem na sociedade, mas, na verdade, criavam no povo um clima altamente desconfortável suscitando nele, continuamente, medos e inseguranças profundas ${ }^{20}$. E, muito embora o desejo de alívio da população, através da extinção daquilo que lhes feria e torturava, na sociedade de Teresa o que se vê é que a presença destes órgãos, ao contrário, tornava-se o seu pão de cada dia $^{21}$.

Com isso, muitas obras foram eliminadas e um número elevado de pessoas banidas, perseguidas, ou condenadas à morte na fogueira. Os livros, particularmente aqueles que ensinavam um caminho de oração à santa e que por ela eram muito estimados, foram incinerados neste fogaréu ${ }^{22}$. Sua própria obra, igualmente: o Livro da Vida foi denunciado à inquisição pela princesa de Éboli e retirado de suas mãos por um período de trinta $\operatorname{anos}^{23}$. Assim, Teresa, junto a outras monjas, sofre a perseguição desta mesma instituição que lhe é tão cara. É pela Igreja acusada de superstição, de alumbradismo $^{24}$, vivendo na própria pele a dor de situar-se no contexto desta realidade cruel, preconceituosa e em ebulição.

\footnotetext{
${ }^{19}$ Idem.

${ }^{20}$ Sobre a inquisição “[...] O caráter cruel e desumano de seu funcionamento talvez não tenha precedentes na história da civilização[...]; Os infratores das regras eram punidos[...] de maneiras diversas: a excomunhão, a confiscação de todos os bens, o exílio, a prisão perpétua, os açoites, as galeras e até a morte na fogueira. Algumas vezes os inquisidores referiam-se com mágoa ao fato de tantos hereges serem queimados, mas confessavam que tinham a missão maior de lhes salvar a alma, mesmo que tivessem de lhes queimar a carne". NOVINSKY, A. W. A inquisição. São Paulo: Brasiliense, 1994. p. 12-20.

${ }^{21}$ Cf. BURGO, L.; NAVARRO, E; GUERRA, A. Para leer... p. 27.

${ }^{22}$ Ibidem. p. 28.

${ }^{23}$ Cf. SANTOS, L. L. Fémina Inquieta y Andariega... p. 39-40.

${ }^{24}$ A Inquisição Espanhola no século XVI perseguia ferrenhamente todas as pessoas que se reunissem nos mais diferentes lugares com o objetivo de ler e comentar a Sagrada Escritura. Ver: WEBER, A. Teresa of Avila and the Rhetoric of Feminity. New Jersey. Princeton: University Press, 1996. p. 22; 99. Leia-se também a respeito de alumbradismo/Teresa e os alumbrados de seu
} 
Contudo, o Espírito Santo que move a sua Igreja para onde deseja ${ }^{25}$ conduzindo-a para uma adequada atualização da verdade de Cristo, inspirava novos métodos para que o Senhor fosse servido com maior fidelidade ${ }^{26}$. Deste modo, esse caráter duro e rijo aos poucos foi se amenizando e, por parte de muitos cristãos, teve um início marcante de superação com o Concílio de Trento. Este foi um dos mais importantes Concílios eclesiais, realizado num período em que a cristandade agonizava e enfrentava todas as espécies de interesses, orgulhos e apetites, inclusive no campo espiritual. Com o Concílio de Trento forma-se uma espécie de base: a doutrina da Igreja fica mais esclarecida, são oferecidas aos cristãos novas obras ${ }^{27}$, se incentiva a disciplina dos costumes $e$ se insiste no senso de Igreja $^{28}$. Ainda, no pós-concílio, apesar de se observar um período de tridentismo, pode-se também colher frutos proveitosos, como, por exemplo, o florescimento da teologia e das ordens religiosas ${ }^{29}$.

É notório saber que esta era contemporânea a Teresa é, ao mesmo tempo, denominada de época das Reformas. A história eclesial, entre outras, dá um acento especial à Reforma protestante. Mas há reforma na política e na sociedade em geral. Há muitos movimentos reivindicando Reformas Religiosas, nesse período, e estes buscavam seriamente, sobretudo, a vida interior, uma maior integridade na fé e a unidade dos cristãos ${ }^{30}$.

tempo: LLAMAS-MARTINEZ, E. Teresa de Jesús y los alumbrados. Hacia una revisón del ‘alumbradismo' español del siglo XVI. In: EGIDO MARTINEZ. T; GARCIA DE LA CONCHA, GONZALES DE CARDEDAL, O. (Orgs.) Actas del Congresso Internacional Teresiano. vol I. Salamanca, 1983. p. 137-168.

${ }^{25}$ Por mover a sua Igreja entende-se aqui a ação de Deus unida à ação humana e não a condição infantil e limitada de encarregar a Deus pelo resultado de todas as coisas, porque como diz Sheldrake "A história também afirma o poder do Espírito Santo para soprar onde deseja e assim nos levar a toda a verdade" SHELDRAKE, P. Espiritualidade e Teologia: Vida cristã e fé Trinitária. Tradução de Ricardo Gouveia. São Paulo: Paulinas, 2005. p. 40. (Coleção Teologia no Espírito).

${ }^{26}$ Cf. HACKMANN, G. L. B. Jesus Cristo, nosso Redentor: Iniciação à Cristologia como Soteriologia. 2. ed. Porto Alegre: EDIPUCRS, 1999. v. 1. p. 232.

${ }^{27}$ Cf. PIERRARD, P. História da Igreja. Tradução de Álvaro Cunha. São Paulo: Paulinas, 1982. p. 188.

${ }^{28}$ Cf. CONGAR, Y. Igreja e Papado: perspectivas históricas. São Paulo: Loyola, 1997. p. 308.

29 "Esse tridentismo é um sistema constituído após o Concílio de Trento sob a influência de papas muito conservadores, como Paulo IV, Pio V, Sixto V e outros. Trata-se de um sistema que englobava absolutamente tudo: a teologia, a ética, o comportamento cristão, a prática religiosa, a liturgia, a organização, a centralização romana, a intervenção perpétua das congregações romanas na vida da Igreja, etc. Na realidade, esse sistema não se confunde com o Concílio de Trento...". Cf. CONGAR, Y. M. Diálogos de Outono... p. 7-8.

${ }^{30}$ Cf. BURGO, L.; NAVARRO, E; GUERRA, A. Para leer... p. 28. 
Nesta panorâmica toda, a Igreja que congrega o povo de Deus e é chamada a iluminar a humanidade com a claridade de Cristo necessita agora repensar sua ação no mundo, sua vocação e missão ${ }^{31}$. Necessita, particularmente, ouvir esse clamor por reforma, que é grande e, ainda, perceber que não há como negar que para a Reforma católica esse é um tempo desafiante, provocativo e intenso.

Aqui o texto não se refere a esta de contra-reforma, como alguns autores denominaram, porque se pondera que a verdadeira Reforma católica não se operou contra um inimigo, mas em favor de Deus e da Igreja. Contudo, o que se pode visualizar de um modo todo especial é que, em benefício desta causa, os agentes principais foram os cristãos convictos, que transformaram este período de dor num verdadeiro renascimento para a Igreja de Cristo. Assim, é neste contexto de grandes inquietações e mudanças que se vislumbra Teresa de Ávila, com sua doutrina exímia. Desponta ela entre os grandes místicos, pessoas dotadas de extraordinária espiritualidade e, com eles, caracteriza o século dos loucos e apaixonados por Cristo ${ }^{32}$.

O que lhes há em comum? Certo senso de fidelidade àquilo que crêem e esperam. Porque é deste modo que, a partir de um fidedigno relacionamento com o Senhor, quando percebem a Igreja e a sociedade notavelmente debilitadas, esforçam-se e doam suas existências para reerguê-las e valorá-las eticamente. E, justamente, por meio desta renovação espiritual, pela fervorosa oração existencial desses cristãos convictos e por seu testemunho de vida é que se propôs à humanidade, um fim às dúvidas, aos relaxamentos e à dicotomização entre a vida e a fé. Qual a mensagem implícita em suas condutas? O anúncio de que é possível mudar os rumos da humanidade, a partir de dentro, a partir de si mesmos, a partir da oração!

Mas esta Teresa de Ávila que brilha junto a esses místicos, seus contemporâneos e, em meio a toda essa realidade de sombras, qual sua origem, de onde surge e quem, de fato, é?!

Muito da estrutura de personalidade e de sua têmpera espiritual vem de seu berço familiar, no qual foi agraciada com pais virtuosos e tementes a Deus que a

\footnotetext{
${ }^{31}$ Cf. DOCUMENTOS DO CONCÍLIO VATICANO II. Constituição Dogmática Lumen Gentium Sobre a Igreja. São Paulo: Paulus: 2001. (A partir de agora será citada por LG). LG. 1, 1.

32 Junto a Santo Inácio de Loyola, São Francisco de Borja, São Pedro de Alcântara, São João da Cruz, entre outros.
} 
educaram com todo o carinho, piedade e dedicação filial ${ }^{33}$. Nasceu em 1515 , em Ávila na Espanha. Sua mãe, descrita, por ela, no Livro da Vida é alguém com saúde débil, amante das leituras dos romances de cavalaria fomentados na época, que falece aos trinta e três anos ${ }^{34}$. Seu pai, homem muito temente a Deus, de bom coração e já viúvo do segundo casamento, tem onze filhos para orientar na vida ${ }^{35}$.

\section{2 .2}

\section{Nascer para uma Vida de Relações}

Com o que ficou registrado ao longo da história, compreende-se que Teresa é, não só mulher de seu tempo, mas também profeta, pois profeta é quem ao mergulhar com profundidade em uma realidade transcendental, dela emerge com uma mensagem nova aos seus semelhantes e, cuja eficácia do anúncio, não se limita ao momento presente, mas se dá para além da história. Sua própria vida de intimidade e de relacionamento com Deus é como o jorrar contínuo de uma fonte que amplia a chama deste profetismo frente a cada novo momento e a cada novo relacionamento que estabelece.

Assim, em Teresa, observa-se que este seu modo de ser mulher e profeta é também o seu modo de se relacionar. Nota-se que, desde a mais tenra idade, o mesmo dinamismo interior que a movia à amizade com Deus, também a suscitava à ação e ao revigoramento das suas relações. Desde pequena lê a vida de santos, brinca com pedrinhas de erigir mosteiros e tem ideais de martírio, ao mesmo tempo em que se mostra bem relacionada com todos, com sua família: pais, irmãos, tios, primos, amigos, religiosos e sacerdotes ${ }^{36}$.

Assim, revela-se com um perfil humano com alto enlevo de sociabilidade: gosta de estar rodeada de amigos, interessa-se em ajudar, é generosa, amável, paciente, cooperativa, convincente, diplomática, sensível. Mostra-se até quase

\footnotetext{
${ }^{33}$ Cf. RUIZ, A. Así era Teresa, Burgos: Editorial Monte Carmelo, 1982. p. 8.

${ }^{34} \mathrm{~V} 1,2$.

${ }^{35}$ Alguns historiadores falam que Alonso teve 10, outros 11 filhos. Tomás Alvarez considera que "Foram muito numerosos os irmãos da Santa: duas irmãs (a primeira e a última na série de filhos de Alonso) e, ao menos oito irmãos com a santa eram onze. Ei-los: Maria de Cepeda nascida por volta de 1505; Juan de Cepeda, 1507; Hernando de Ahumada, 1510 Rodrigo de Cepeda 1511; Teresa de Ahumada, 1515; Lorenzo de Cepeda, 1519; Antônio de Ahumada, 1521; Jerônimo de Cepeda, 1522; Agustín de Ahumada, 1527, e Juana de Ahumada, 1528. Os dois primeiros pertencem às primeiras núpcias de Alonso. Há antigos historiadores que falam de um terceiro filho dessas núpcias, um certo Pedro, de quem nada de concreto se sabe". ALVAREZ, T. Nota 4 . V 1.

${ }^{36}$ Cf. V 1,4; V 2,4; V 4,7; V 7,1.1
} 
como alguém necessitada da cumplicidade das pessoas para tudo o que se propunha. Tanto, que ao bom historiador, ao observá-la e averiguar como é definida pelos demais, caracteriza-a como amiga, humana e empática, sendo impossível não percebê-la como uma personalidade notável e sempre em relação. Frei Maximiliano Herraiz, numa frase, conclui: "Era uma mulher muito inteligente, gostava de fazer amizades e tinha o dom de unir as pessoas, esta será uma característica forte na sua espiritualidade" ${ }^{\natural 3}$. Um exemplo concreto desta cumplicidade é o fato de, ainda menina com sete anos, após a leitura do Flos Sanctorum $^{38}$, decidir ir com seu irmão Rodrigo de nove anos, à terra dos mouros para ali realizar o martírio. Algo que lhes era muito sedutor e parecia-lhes, ao mesmo tempo, bem real e possível ${ }^{39}$.

Esta fuga infantil, celebrada como uma das aventuras mais significativas da sua vida mística, papa Gregório XV registrou-a em seu processo de canonização, convicto de que este ideal de dar sua vida à Deus esteve sempre presente nas suas grandes conquistas, enquanto fundadora, escritora e reformadora ${ }^{40}$. Mas, Teresa não é identificada como uma mulher de oração, de relações, destemida e criativa, somente por seu grupo familiar e religioso, mas por isso, é mundialmente reconhecida $^{41}$, o que explica a ampla expansão da vida e da obra da mística ${ }^{42}$.

Assim, nota-se que, sua abertura às relações é visível desde os pequenos gestos de trocas que se dão na inter-relação, intra, ou extra-conventual, até a

${ }^{37}$ Cf. HERRAIZ GARCIA, M. Santa Teresa de Ávila, amiga de Deus e dos homens. Disponível em http://www.comshalom.org/formacao/santos/sta_tereza.html, acessado em 06.05.2012, às 18h.

${ }^{38}$ O Flos Sanctorum era uma "Extensa coleção de relatos da vida de santos, que trazia histórias reais ou fantasiosas desde os mártires romanos, até os santos canonizados no período medieval, datado de 1513". STEGGINK, O.; EFREN DE L.M.D. Tiempo y vida... p. 35.

${ }^{39}$ Cf. AUCLAIR, M. Teresa de Ávila... p. 18-19.

${ }^{40}$ Cf. STEGGINK, O.; EFREN DE L.M.D. Tiempo y vida... cit. p. 37.

41 “As edições das obras teresianas na segunda metade do século XIX, além de conseguir um ritmo de aceleração numérica progressiva, apresentam uma particularidade que lhes imprime o espírito novo daqueles tempos passam a formar parte das grandes coleções de autores clássicos, místicos ou universais. Até setenta e duas impressões das obras da Santa, totais ou parciais, aparecem entre 1841 e 1896". SANROMÁN, J. B. Anteriores Centenários de la muerte de Santa Teresa. Revista de Espiritualidad: Santa Teresa en su ambiente histórico. Madrid: vol. 40. n. 159-160. p. 351, 1982.

${ }^{42}$ No contexto apareceram as primeiras edições fac-símiles dos livros escritos por Santa Teresa de Jesus "(feito que seria repetido apenas a partir de 1965 com a publicação de "Camino de Perfección", alguns certames literários temáticos sobre a monja (inclusive um organizado por poetisas espanholas) e, mais importante, o resgate definitivo para a Ordem do Carmelo Descalço da casa em que Teresa teria nascido, com a transformação do prédio em "Museu teresiano". Da mesma forma cabe citar que outros conventos fundados pela religiosa começaram a organizar exposições de relíquias da Santa, transformando-se, pouco a pouco em verdadeiros museus". SANTOS, L.L. Fémina Inquieta y Andariega... p. 43-44. 
expansão de sua obra além-mares. Nos seus entes mais próximos experiencia como que em laboratório o exercício do dom privilegiado de cuidados com que o Senhor a favoreceu: na generosidade de ser mãe, referência e mestra para muitas pessoas e grupos. Neste sentido dedica-se, no seu cotidiano, ao amparo de seu grupo familiar, mesmo após monja. Também à sua comunidade religiosa, no desvelo com a formação das suas co-Irmãs, demonstrando sempre efetivo interesse em torná-las, comunicáveis e cultas ${ }^{43}$.

Quanto às relações externas, o mesmo dito às monjas, diga-se em relação à comunicação e à orientação aos teólogos que se aproximam da santa, muitos dos quais participarão do Concílio de Trento. Além disso, Teresa está continuamente atenta à busca de informações sobre os acontecimentos da cidade, da Igreja, sobre as missões, sobre as Índias ${ }^{44}$. O medo de se desenclausurar ${ }^{45}$ não a barra, mas supera-o pela ousadia, pois embora monja, abre-se sempre. Teresa abre-se no espaço em que se insere e ao desconhecido. Sai de si mesma, de seu próprio habitat ao encontro de todos e, deste modo, externaliza a eficácia da ação de Deus na pessoa orante e o quanto a oração coaduna-se e integra-se no cotidiano da vida. Evidencia-se, tanto pioneira, quanto sensata na sondagem e preparação dos locais onde fundará seus conventos, abrindo-se ao registro de uma história, na qual está consciente do seu comprometimento com os irmãos e irmãs e com o futuro que irão viver.

É também dedicada e zelosa na autoria das inúmeras cartas e obras. Abre-se, desta forma, à cidadania, fazendo-se uma cidadã respeitável ${ }^{46}$. Diante dos desafios da sua Igreja e pátria, mesmo na conjuntura de seu tempo, não se sente dispensada da democracia, mas ao contrário, aprimora sua responsabilidade social na preocupação e no acompanhamento, inclusive com participação ativa no curso do governo de sua época. De modo especial, posiciona-se de maneira respeitosa e interpeladora, no diálogo com o Rei Felipe II, sem contudo, assimilar o projeto de sua reforma intolerante e opressora ${ }^{47}$. Nota-se, deste modo, que sua atuação dá-se

\footnotetext{
${ }^{43}$ Cf. V7,1.

${ }^{44}$ Cf. PEDROSA-PADUA, L. Vida e Significado... p. 31.

${ }^{45}$ Nota-se aqui que as Carmelitas vivem em clausura. Faz parte da regra de sua Ordem não só o silêncio, como também o viver no recolhimento dentro dos claustros de algum convento.

${ }^{46}$ Vejam-se, por exemplo, as cartas ao Rei Felipe II no qual Teresa critica o rígido sistema social baseado na honra, poder e riqueza, pois o caráter crítico-libertador faz parte da espiritualidade teresiana. Cf. PEDROSA-PADUA, L. Vida e Significado... p. 31.

${ }^{47}$ Cf. CASTANHEIRA AVELAR, M. C. Experiência Mística... p. 28.
} 
desde uma realidade conventual, mas sua ousadia é extra-conventual, também política, dado participar, opinar, dar conselhos e estar ciente de que vive num tempo onde intensos conflitos sociais se proliferam. Por fim, tão aberta às relações foi Teresa que sua vida e obra seguem, ao longo da história e, até hoje, enriquecendo-se com novos membros, novas associações e novos institutos.

\subsection{3}

\section{Nascer para Deus: Vossa sou, para vós nasci}

Vossa sou, pois me criastes, vossa, pois me redimistes, vossa porque me atraístes, vossa porque me suportastes, vossa porque me esperastes, vossa, pois me salvastes: Que mandais fazer de mim? ${ }^{48}$

Viu-se no ponto anterior que nascer para uma vida de relações significa, ao mesmo tempo, abrir-se ao existir, a uma vida ainda mais plena, que por si mesma, em sua naturalidade, compreende-se como aproximação e elevação ao transcendental, ao Sagrado e aos irmãos. Ora, Teresa sente o convite a esta união e comunhão com Deus e coloca-se "continuamente diante deste mistério incomensurável do amor, que ela mesma contempla"49, tanto que sua profunda convicção a esse respeito leva-a a redigir uma poesia com este teor "Vossa sou, para vós nasci" ${ }^{, 50}$, hoje lema na preparação da celebração de seu quinto centenário.

Neste processo, como que de atração, ou de ascensão ao Mistério, Teresa inclina-se à Presença Inebriante de Deus, à graça que a envolve. Somente na abertura e na profundidade mais íntima poderá percebê-lo, enquanto Mistério de Luz Inefável e em cuja luminosidade, desde seu cerne, por mais que alguém se aproxime, será sempre Mistério que não se esgota. Porque,

a inefabilidade não é um silêncio vazio, mas sim a escuta de uma Presença. Por mais que se fale de Deus muito mais ainda fica por dizer, pois Deus mesmo é Presença inesgotável. A experiência só faz aumentar o seu mistério. A aproximação ao mistério faz ver sua grandeza inescrutável. Ele transcende o pensamento como o impensável, o inimaginável. Transcende também as experiências, é o não experimentável em sua radicalidade ${ }^{51}$.

\footnotetext{
48 SANTA TERESA DE JESUS. Poesias. In: SANTA TERESA DE JESUS. Obras Completas. Poesias. Revisada e anotada por Frei Tomás de La Cruz. Coordenação Frei Patrício Sciadini. 2. ed. São Paulo: Loyola, 2002. (A partir de agora será citada por P, acrescido da numeração correspondente). P II.

${ }^{49}$ PEDROSA-PADUA, L. Espiritualidade integradora... p. 183.

${ }^{50} \mathrm{P}$ II

${ }^{51}$ PEDROSA-PADUA, L. Vida e Significado... p. 44.
} 
Esse Mistério torna-se a fonte de esperança para Teresa que sabe que Deus pode muito mais e, por isso, dele pode-se crer e esperar sempre mais. Deste modo, compreende-se que a forte consciência que Teresa tem de nascer para Deus é o que a leva à descoberta de uma relação pessoal de amizade com o Senhor e a ficar aberta e atenta à novidade de Deus, à novidade de Sua salvação e de Sua Presença. Esse tipo de escuta exige um coração permeável à contemplação do amor e da vida que Ele oferece a todos ${ }^{52}$. Nela lança os fundamentos da relação que depois irá oferecer ao mundo como possibilidade autêntica de relacionamento com o divino a tantas pessoas que irão buscar em seus escritos orientações à vida.

Pode-se ver, nesse sentido, que em Teresa de Jesus, a amizade com o Cristo encarnado: Aquele que sentiu as emoções, as alegrias, as dores, os desconfortos, a fé, o aconchego, ou o desamparo de seu povo, Aquele Cristo que come, chora, ri, prega, orienta, profetiza, sente ira, medo, abandono e que é descrito por ela como Sagrada Humanidade, a levará a um encontro decisivo e profundo consigo mesma $^{53}$. É o mesmo Cristo, que viveu a vida humana o que sabe até onde a pessoa pode chegar. Este é o que se torna Modelo de vida para Teresa e para todos. É o que a prepara, interpela e a conduz no processo do seu desenvolvimento pessoal e na interação com os irmãos. Assim, é o Cristo encarnado e ressuscitado, quem a provoca a uma radical mudança de vida, que se dará, eficazmente, próximo de seus quarenta $\operatorname{anos}^{54}$, não obstante toda a sua vida ter sido orientada ao Senhor ${ }^{55}$. Esse relacionamento profundo de amizade com Cristo, na vivência cotidiana de oração a faz defender uma tese: a tese do Amor de

${ }_{53}^{52}$ Cf. PEDROSA-PADUA, L. Espiritualidade integradora ... p. 185.

${ }^{53}$ Para diversos autores não basta falar da presença central de Cristo, necessita-se determinar como se entende esse Cristo, pois a compreensão de Cristo para muitos fica redimensionada pelo neoplatonismo, onde o humano de Cristo é somente um meio, ou instrumento para a comunicação com o divino. No caso de Teresa está-se ante uma unidade total. Trata de um Cristo onde Deus alacança a pessoa através da sua Humanidade. Sagrada Humanidade para Teresa é o Cristo glorioso, conotado ao histórico. "Quase sempre o Senhor aparecia a mim em Sua forma de ressuscitado, o mesmo ocorrendo na Hóstia. Algumas vezes, para me revigorar, quando eu passava por tribulações...”. V 29,4; Cf. TORRES SÁNCHEZ, S. Mística y cristología. In: CASTRO, S.(Org). Teresa de Jesús... p. 81-82.

${ }^{54}$ Cf. AlvareZ, T. Comentarios a las Obras de Santa Teresa "Libro de la Vida", "Camino de Perfección" y "Castillo Interior": Para la reflexión y oración personal y de grupo. Burgos: Editorial Monte Carmelo, 2005. p. 60-61.

${ }^{55}$ Nota-se que o crescimento de Teresa para a profunda vida mística não foi algo linear, dado sua luta, mesmo após monja da Encarnação. Necessita desprender-se de certa vida de frívolas amizades, visitas constantes que a afastavam do seu ideal, fazendo-na viver uma existência medíocre, com dificuldade de orar (por mais de 18 anos). Tempo longo, onde separava Deus e o mundo (influência platônica, conforme costume na Vida Religiosa de então). Isso até a profunda e aspirada conversão que a desperta a um amor mais elevado e apaixonado pelo Senhor. A partir daí foca o essencial, tem uma amizade personalizada com Cristo, integra a vida e os relacionamentos. 
Deus para com a humanidade, a tese da sua grande misericórdia para com cada pessoa. Por isso, diz que: "o amor de Deus não tem medida e, portanto não têm medida seus dons e a sua misericórdia" ${ }^{, 56}$. Após este encontro vital, falar do relacionamento com Cristo, do amor e da Caridade de Deus tornam-se a predileção de Teresa. Portanto, vê-se que a mística torna-se o núcleo da obra de Teresa que crê que a espiritualidade, sendo assimilada e vivida como encontro pessoal e de amizade, com Cristo encarnado, leva a pessoa a uma entrega incondicional ao Mistério de Deus. Assim, para Teresa orando abre-se a porta, o caminho para se acolher, para se aprofundar a verdade do amor de Deus e, orando encontra-se a fonte de cultivo do amor e da inter-relação com os irmãos. À luz da força deste momento pessoal com o Mistério de Deus, no Cristo que se encarna, manifesta com maturação humana e espiritual que Cristo está vivo e entre nós!

À luz deste encontro, onde todo o seu ser se entrega, por inteiro Àquele que ama, nasce o discernimento e a lucidez de seu sentido de viver. À luz de Cristo encarnado e ressuscitado, gradativa e intensamente viverá o amor, sendo capaz de ser essa grande personalidade, essa mulher de fibra, de caráter, atenta à comunicação e aos movimentos de seu povo, perspicaz às realidades internas e externas, ativa na expressão, na singeleza e na expansão de sua missionariedade.

Portanto, o relacionamento com o Senhor, quando comprometido e encarnado na humanidade dos irmãos, assemelha-se a Cristo: é frutífero e auxilia a pessoa a compreender que se nasce para Deus, nascerá para os irmãos, pois como diz Jesus: "Quem permanece em mim e eu nele, esse dará muito fruto"

\subsection{4}

\section{Nascer para os irmãos}

Viu-se anteriormente, que Teresa nasce para Deus e, ao mesmo tempo, nasce para os irmãos. Isso de tantos modos, em tantos momentos e em tantas culturas distintas. Nasce para a família, para as monjas, para os carmelitas Calçados e Descalços. Para sua Ordem inteira, para a sociedade de seu tempo e de tantos outros tempos. Nasce para os amigos de sua época e a tantos outros amigos

\footnotetext{
${ }^{56} 7 \mathrm{M} 1,1$.

${ }^{57}$ Jo 15,5 .
} 
que terá ao longo da história ${ }^{58}$. Hoje continua viva, relacionando-se com cada um, através da obra que deixou como legado, particularmente através de seus escritos nos quais, ao escrever, fala com o leitor, a ponto de fazê-lo amigo e de deixar a impressão naquele que a lê de que dialoga com ele, conforme diz Tomás Alvarez:

Ela consegue falar com o leitor, apesar do papel e da pena, como fala com seu grupo de monjas na sala capitular e no recreio, ou como faz em tantas de suas cartas. E como o faz com Deus, quando interrompe o relato para iniciar o solilóquio ${ }^{59}$.

Ela própria dá-se conta disso e, propõe-se a isso, quando expressa: "Falarei com elas naquilo que vou escrever" ${ }^{\prime \prime 0}$. É seu jeito. Num primeiro momento, tornase amiga, convida a uma proximidade aconchegante para, depois, falar a todos do amor de Deus, da necessidade de se relacionar com Ele, da possibilidade de conhecê-lo melhor na oração e na vida, descobrindo-se aí Aquele a quem tanto se ama, num rosto humano tão próximo. É seu modo de mostrar que a mística não invade. Também não se intimida, nem se cala. Nem por palavras, nem por obras!

Assim, ao investir em seus relacionamentos Teresa não tem medo de evangelizar, de glorificar o nome d'Aquele que por primeiro se fez seu Amigo e Quem dela merece todo o louvor. Desta amizade com Cristo nasce a coragem, brotam avanços, como respostas determinadas e destemidas ao convite de amor apaixonado que Ele lhe faz. Ligando-se estas à fidelidade ao Senhor, a quem serve e a quem ama, fazem-na reafirmar os laços profundos de amizade entre os irmãos.

Por isso, cheia de vivacidade, de bom humor, de capacidade de equilibrar todas as coisas e através de seu comportamento: questiona, interpela, interage, leva à Deus. É deste modo que para tantos, Teresa se torna a conselheira ou, como preferem alguns, a psicóloga nata que acolhe, ouve, discerne e orienta, acenando às pistas mais interessantes que vão ao encontro das necessidades e à interioridade de cada qual. Tem sempre uma palavra para todos, tanto aos que estão ao seu redor, como aos mais distantes. $\mathrm{Na}$ amplitude da sua afetividade e generosidade é capaz de abarcar a uma multidão de pessoas, as quais expressará seu maior carinho, sua solidariedade, sempre com a intenção de incluir, de levar os amigos a

\footnotetext{
${ }^{58}$ As cartas do epistolário teresiano mostram o quanto Teresa relacionava-se intensamente com tantas pessoas, por isso "nasce" para todos.

${ }^{59}$ ALVAREZ, T. Introdução às Obras Completas. In: SANTA TERESA DE JESUS. Obras Completas... p. 11.

${ }^{60}$ ALVAREZ, T. Introdução ao Castelo Interior ou Moradas. In: SANTA TERESA DE JESUS. Obras Completas... p. 440.
} 
uma maior relação entre si e com Deus. Ao fazer esta liga integradora às dimensões da personalidade e ao conduzir as pessoas a uma abertura cada vez maior à Deus e aos irmãos, além de espiritual, mostra-se humana e relacional.

Desta forma é que Teresa nasce aos irmãos, convidando-os a alimentaremse da esperança de um mundo mais justo, solidário e fraterno. Assim é que incentiva a humanidade, pois compreende, que se a amizade estiver estabelecida em sólido fundamento, com certeza, cada vez mais levará ao desenvolvimento humano e à Deus. Por isso, está convicta de que, ao interagir com os outros, vivenciando valores nos quais crêem, os amigos se proporcionarão, mutuamente, reais condições para viver bem a própria vida, em todos os seus campos. Porque na amizade, entre os que se assemelham na busca de Deus, encontram-se suportes de apoio e de entre-ajuda saudáveis para se acolher os muitos desafios com os quais a vida e a fé, por vezes, os surpreendem. Desta forma e, com razão, a religiosa postula que a amizade entre aqueles que perseguem a via da espiritualidade só poderá ajudá-los a prosseguir no caminho para Deus, em direção à vida plena. Isso justifica seu conselho: "aqueles que são amigos de Deus, deveriam também ser amigos entre si"61. Esta convocação, este apelo interior à amizade, humana e espiritual, não se faz sentir com pouca força no interior de cada pessoa, mas é um grito suave e ao mesmo tempo impetuoso do coração, particularmente para aqueles que levam a sério o seguimento de Cristo, a relação de amizade com o Cristo encarnado, uma vez que: "renunciar a viver uma experiência de amizade é renunciar a viver seriamente o Evangelho ${ }^{62}$. Assim, viver sem amizade, sem investir em relacionamentos, sem nascer para os irmãos, seria o mesmo que uma desumanidade! Sua consequiência é a desintegração do humano, que se fecha à inter-relação, pois não consegue compreender a essência do cristianismo, nem a dignidade do chamado de Deus às grandes realizações ${ }^{63}$.

\footnotetext{
${ }^{61} \mathrm{~V} 8,5-6$

${ }^{62}$ ALAIZ, A. $O$ valor da amizade. 3. ed. São Paulo: Paulinas, 1986. p. 48.

${ }^{63}$ "Considero a ausência de amizade uma forma de [...] desumanização". ALAIZ, A. $O$ valor da amizade... p. 09.
} 


\section{2 .5}

\section{Nascer mulher}

Numa sociedade em que a mulher não tinha vez, nem voz, particularmente na Espanha do século XVI, com a liderança delegada aos homens aguerridos, rígidos e armados, como se viu, anteriormente, Teresa nasce mulher. Já desde seu contexto familiar a masculinidade predomina, pois excetuando Teresa, sua irmã mais velha e a menor, todos os demais na casa são homens. O pai sobrevive. Muito frágil, a mãe falece ${ }^{64}$. Como herança de sua mãe recebe a devoção à Maria, oferecida como modelo de existência. Esta será sua forte companheira, por toda a vida, na trajetória carmelita, onde essa referência feminina é imitada e venerada.

Ela mesma testemunha que sua mãe lhe inculcou o amor à Virgem e a introduziu na prática da oração do rosário $(\mathrm{V} 1,1.6)$ e ao morrer aquela, em um ato de grande intensidade humana e religiosa, se prostrará ante uma imagem de Maria para pedir-lhe que faça-lhe, as vezes de mãe $(\mathrm{V} 1,7)^{65}$.

Não obstante todo esse desafio de fé, Teresa descobre-se feminina. Era vaidosa, usava perfumes, arrumava os cabelos, enfeitava-se para os meninos, queria agradar. Naturalmente, respeitando seu ritmo de desenvolvimento humano, que passa por todas as etapas de crescimento de uma menina-moça ${ }^{66}$. Desde criança reconhece como bênçãos suas virtudes e as graças que Deus lhe deu como dons naturais: beleza, afeto, inteligência, tendo consciência de suas possibilidades: "Comecei a entender as graças da natureza que o Senhor me havia dado - que segundo diziam, eram muitas" ${ }^{\prime 67}$. Tendo nascido para Deus, para os irmãos $e$ nascido mulher, como poderia não reconhecê-las?

Seduzida por livros de cavalaria e à imitação da mãe, lia-os às escondidas do pai, que sempre se mostrava piedoso e interessado em boas leituras para seus filhos ${ }^{68}$. Conta-nos, que motivada por este costume (leitura dos romances de cavalaria) começou a vestir-se "com elegância, a querer agradar e a parecer bonita", hábito a que posteriormente renunciaria em nome de uma vida mais

64 “La inferioridade de la mujer se intentaba demonstrar en todos los campos de la vida cotidiana. No sólo era una inferioridad fisiológica: la valoración del cuerpo feminino sólo fue positiva en el terreno artístico durante el Renacimiento, y en un corto espacio de tempo". TORRES SANCHEZ, C. La Salamanca clausura feminina en la del siglo XVII: domenicas y carmelitas Salamanca: Ediciones Universidad, 1991. p. 50

${ }^{65}$ TORRES SÁNCHEZ, S. Mística y cristología... p. 84.

${ }^{66} \mathrm{~V} 2,2$.

${ }^{67} \mathrm{~V} 1,9$.

${ }^{68}$ Cf. V 2,1. 
recatada e dedicada a Deus e à Igreja ${ }^{69}$. Renunciaria, sim, mas não totalmente, pois esta natural vaidade, mesmo com sua opção vocacional, sutilmente pode ser identificada na monja, mais tarde como, por exemplo, em 1576, no momento que posa para Juan de la Miséria (Giovanni Narduch), o carmelita que pintou o único retrato legítimo de Teresa. Ao vê-la concluída, com seu fino humor, reclama: "Deus te perdoe frei Juan por me teres pintado feia e remelenta"

Provavelmente Juan e Teresa jamais imaginariam que sua obra, que não se assemelha a um quadro de Velásquez, nem chega aos pés de Bernini, tornaria-se tão importante para as gerações posteriores. A pintura de Juan de la Miséria é a que ilustra atualmente inúmeros livros e souvenirs vendidos na cidade de Ávila, na Espanha, onde Teresa como a modelo do quadro é o principal ícone turístico ${ }^{71}$.

Ciente de sua feminilidade, demonstra adequada estima de si mesma e faz uso de sua condição de mulher no contexto no qual se situa, colocando-se num lugar feminino apropriado para dali maturar-se como mulher e reivindicar à sociedade em que vive, à Igreja e ao mundo, a dignidade e o protagonismo que lhes são devidos ${ }^{72}$. Desta maneira, para a cultura e para a referência pessoal:

A vida de Santa Teresa, em si mesma, é fonte de diversos significados, tanto éticos quanto religiosos e cristãos. Mulher forte e corajosa, amiga do amor e da amizade, da liberdade e da pobreza, da humildade e da verdade, do bom humor e da alegria, da beleza e da poesia, Teresa foi uma mulher humana e de Deus ${ }^{73}$.

No desabrochar de sua vitalidade de mulher, como se pode observar em algumas passagens de suas obras, Teresa demonstra o quanto:

1 Vive sua feminilidade, expressando-se como mulher, não colocando o foco na sequência do que não tem por fim a glória de Deus, mas em suas convicções, mesmo em meio à incompreensão e ao desrespeito:

Enquanto viveu, Madre Teresa era mal vista[...]. É o caso do núncio papal Filipe Sega, que, em certa ocasião, teria chamado a Madre de 'mulher irrequieta

${ }^{69}$ Cf. SANTOS, L. L. Fémina Inquieta y Andariega... p. 19.

${ }^{70}$ STEGGINK, O.; EFREN DE L.M.D. Tiempo y vida de Santa Teresa... p. 592.

${ }^{71}$ Cf. SANTOS, L. L. Fémina Inquieta y Andariega... p. 23.

${ }^{72}$ Neste contexto de realidade, na Igreja a mulher era submissa, contudo por ser um período onde o humanismo despontava, "En la Iglesia de la Renacimiento aún se mantenía la paradoja de que la mujer es débil pero sustiene al mundo. Esta idea daba lugar a todo un sistema pedagógico que en el fondo era contraria a los intereses de la mujer limitaba su independência y sus capacidades y la convertía en un instrumento divino puesto al servicio del mundo. La Iglesia mantiene a la mujer en segunda fila dentro del elemento humano y da su modelo a través de sus tratados pedagógicos. Este modelo tendría como cualidades especiales: la paciência, la dedicación familiar, el encierro interior y el rechazo de lo mundano". Cf. TORRES SANCHEZ, C. La clausura feminina.... p. 51.

${ }^{73}$ PEDROSA-PÁDUA, L. Apresentação. In: PEDROSA-PÁDUA, L.; CAMPOS, M.(Orgs.). p. 7. 
e andarilha, desobediente e contumaz'. Acusava a santa ainda de 'inventar más doutrinas, sair da clausura, apesar da proibição do Concílio de Trento, e de ensinar, apesar de São Paulo ter mandado que as mulheres se calassem na Igreja $^{74}$.

2 Aspira uma relação de complementação entre o homem e a mulher, não de assujeitamento de uma das partes, como por exemplo, ao pronunciar-se: "Dizem que a mulher para ser bem casada deve agir com o marido da seguinte maneira: mostrar-se triste quando ele está triste e alegre quando o vê alegre, mesmo que nunca o esteja"75. Nota-se na conclusão de sua fala, a denúncia: "Vede, Irmãs, de que sujeição vos livrastes!",76.

3 Aponta Cristo como modelo ideal para o mútuo reconhecimento dos gêneros:

E isso com sinceridade e sem fingimento o Senhor faz conosco: Ele se sujeita, desejando que sejais a senhora e Lhe imponhais a vossa vontade. Se estais alegres, Vede-O Ressuscitado[...]. Com que esplendor, com que formosura, com que majestade, quão vitorioso, quão alegre! Como quem se saiu bem da batalha onde conquistou um reino tão importante, que Ele deseja dar-vos, por inteiro, junto Consigo. Assim, será muito que volteis os olhos de vez em quando para Aquele que tanto vos dá? ${ }^{77}$

4 Tem uma linguagem típica feminina, mesmo inserida num contexto masculino:

[...] linguagem, lemos com prazer suas obras cheias de sinceridade e verdade, beleza e concretude cotidiana, humor e criatividade. Como mulher, sua linguagem é pluridimensional. Isenta da impessoalidade e rigores escolásticos, a cujos conteúdos e métodos [...] teve pouco acesso. Segundo o objetivo de cada obra[...] se esforça por dar-se a entender, com habilidade e inteligência. Ora direta e grave; ora narrativa e simbólica, cheia de emoção e de assombro. Sua linguagem é plástica e adaptada a melhor expressar-se,[...] como [...] seu corpo e sua disponibilidade interior ${ }^{78}$.

5 Advoga em causa própria e das demais mulheres, mostrando Cristo como Modelo para a postura de respeito dos homens frente à consciência do papel e ao protagonismo da mulher na Igreja e na sociedade: "quando andastes pelo mundo Senhor não desprezastes as mulheres, ao contrário"79.

${ }^{74}$ RIBEIRA, F. Vida de Santa Teresa de Jesus. 3. ed. Barcelona: Gustavo Gili Editor, 1908. p. 30.

${ }^{75} \mathrm{C} 26,4$.

${ }^{76}$ Idem.

${ }^{77}$ Idem.

78 PEDROSA-PÁDUA, L. Mãe da Psicologia. PEDROSA-PÁdUA, L. Mãe da Psicologia subjetividade e liberdade. Disponível em htpp://www.ihu. unisinos.br/entrevistas/505364-em edição-mae-da-psicologia-cubjetividade-liberdade-e-autonomia-em-teresa-de-jesus-entrevista-es pecial-com-lucia-pedrosa. Acessado em 12 de maio 2012, às 14h.

${ }_{79}$ PEDROSA-PADUA, L. Vida e Significado... p. 30; Cf. PEDROSA-PADUA, L. Espiritualidade Integradora... p. 187. 
6 Sonha com uma Igreja na qual mulheres podem se posicionar publicamente, onde possibilidades não são limitadas, onde há relação de igualdade de direitos ${ }^{80}$.

Sua famosa oração, verdadeiramente feminista, encontrada na primeira redação do Caminho de Perfeição(cap. 4,1). Nela, denuncia um "encurralamento" das mulheres na Igreja: os varões são juízes de mulheres e suspeitam de toda "virtude de mulher"; estas, por sua vez, não podem "falar algumas verdades" que "choram em segredo", são desprezadas e desqualificadas. Evidentemente, esta página foi censurada e não passou à segunda redação do mesmo livro ${ }^{81}$.

E é assim que na oração e na vida:

Como sujeito da experiência[...] Teresa foi refeita como mulher. Adquiriu apuradíssima autoconsciência de seu ser mulher. Rejeitou os estreitos papéis pré-estabelecidos e ultrapassou vários limites impostos culturalmente às mulheres. $\mathrm{O}$ fato de ser fundadora de uma ordem religiosa feminina e masculina bem o demonstra. Foi até chamada de "homem e dos muito barbados", por um catedrático de Salamanca, que observou sua capacidade de gestão ${ }^{82}$.

Desta maneira, esta grande mulher permanece na história e nas diferentes culturas e, assim:

Teresa forma um movimento de mulheres pobres, orantes e iguais. Sustenta essa reforma através de uma verdadeira rede de comunicação e solidariedade e a fortalece com uma espiritualidade forte, para amigos fortes de Deus. Escreve sobre a oração e orienta a vida de fé e de oração de religiosos e leigos. Seus escritos são um documento vivo da situação de seu tempo e revelam uma espiritualidade militante, feminista, profética e audaz, ao mesmo tempo, embebida na amizade e no amor de Deus. Este é um dos motivos de Teresa inspirar caminhos e vivências dentro e fora do cristianismo ${ }^{83}$.

Esta militância feminina percebida na sua perspicácia, no seu modo gracioso e simples de viver, na sua escuta atenta, acompanha o movimento da vida, do trabalho, da troca de afeto e de cuidados e mostra o quanto sua vida é conduzida pelo Espírito e pela ação de Deus ${ }^{84}$. Sendo a primeira mulher a empreender a reforma de uma Ordem masculina, além do ramo feminino é interessante perceber que é vista tanto por homens, como pelo ramo feminino, como uma mulher excepcional $^{85}$. A Igreja a reconhece como mãe e mestra e vê em seu doutorado um "magistério espiritual de primeira grandeza" 86 .

\footnotetext{
${ }^{80}$ Cf. PEDROSA-PÁDUA, L. Vida e Significado... p. 30.

${ }^{81}$ PEDROSA-PÁDUA. Mãe da Psicologia... Acessado em 12 de maio 2012, às $18 \mathrm{~h}$.

${ }^{82}$ Idem.

${ }^{83}$ PEDROSA-PÁDUA, L. Vida e Significado... p. 187.

${ }^{84}$ Ibidem. p. 31.

${ }^{85}$ Expressão de Paulo VI na homilia da missa de proclamação do doutorado de Santa Teresa, em 27 de setembro de 1970. Cf. MELÚS, R. M. L. Santa Teresa de Jesus. Reformadora do Carmelo, n. 3. Espanha: CESCA (Centro de Espiritualidad Carmelitana), 1978, p. 26.

${ }^{86}$ ALVAREZ, T. Introdução às Obras Completas. In: SANTA TERESA DE JESUS. Obras completas... p. 5.
} 
Quando faleceu, no dia quatro de outubro de 1582, com 67 anos, seu corpo foi mutilado e doado como relíquia para diferentes partes do reino espanhol, segundo a religiosidade da época ${ }^{87}$. Foi beatificada em 24 de abril de 1614, por Paulo V. Em 16 de novembro de 1617, foi declarada patrona da Espanha pelas cortes espanholas. Foi confirmada neste título em 1627, pelo Papa Urbano VIII. Em 12 de março de 1622, foi canonizada por Gregório $\mathrm{XV}^{88}$ e, por fim, a 27 de setembro de 1970, declarada a primeira mulher doutora da Igreja Universal, por Paulo VI, ao lado de Catarina de Sena ${ }^{89}$. E para quem não a conheceu em vida, dizia Frei Luís de Leon: "pode ainda conhecê-la em duas perfeitas imagens que deixou de si: suas filhas e seus livros, ${ }^{, 90}$.

\section{3}

\section{Celebrar a vida em relação, fecunda e permanente}

Este ponto detém-se no reconhecimento da mística, na vida e obra de Teresa. Fala de sua fé, sua ousadia, sua presença na história e de como, hoje, a santa é assinalada como referencial para a vida de tantas mulheres deste tempo.

\subsection{1}

\section{Reconhecimento da mística, da vida e da obra de Teresa}

De acordo com Alison Weber, o reconhecimento póstumo de Teresa deu-se, sobretudo, devido aos contatos com a nobreza castelhana (de modo especial com o monarca Felipe II), para a qual marcou presença com seu carisma pessoal e persuasão na escrita, toques típicos da retórica teresiana. Estes somados à produção de incontáveis relatos biográficos, em diversos estilos, particularmente de carmelitas descalços ${ }^{91}$, procuravam mostrar Teresa, nas suas diversas facetas. A história considera, ainda, a evolução das interpretações das várias Teresas

\footnotetext{
${ }^{87}$ Cf.AUCLAIR, M. Teresa de Ávila... p. 401-404.

${ }^{88}$ Cf. MELÚS, R. Santa Teresa de Jesus... p. 24.

${ }^{89}$ Cf. SCIADINI, P. Teresa d'Avila. São Paulo: Salesiana Dom Bosco, 1982. (Coleção Heróis n. 21).

90 CARMELITAS do Convento de Santa Teresa do Rio de Janeiro. Santa Teresa de Jesus. Moradas, Caminhos. Por ocasião do IV Centenário da morte da Doutora Mística 1582-1982. Rio de Janeiro: Cartas Marco's, 1981. p. 23.

91 Cf. WEBER, A.. Teresa of Avila... p. 26-27; Cf. SANTOS, L. L. Fémina Inquieta y Andariega... p. 27.
} 
concebidas, desde a original, passando pelo acréscimo das roupagens específicas nos diferentes contextos das diferentes épocas, até a descoberta de alguma identidade peculiar que se-lhe aproxima, alguma imagem que, de certa forma, seja mais fidedigna da própria Teresa de Ávila. Deste modo, pode-se avalisar o reconhecimento de sua real contribuição, considerando que

Autores de todas as épocas e nacionalidades e a partir das mais distintas abordagens escreveram sobre Santa Teresa. Para eles ela foi escritora, mística, mulher, religiosa, santa castelhana, descendente de judeus, a mais pura das nobres cristãs e até epilética. Todas estas interpretações ajudaram a forjar as várias 'Teresas': desde a 'mulherzinha' inquieta $e$ andarilha de meados do século XVI, até a Santa Madre de $2006^{92}$.

É importante ter presente que algumas publicações significativas, ligadas geralmente a jesuítas influentes na sociedade iam pontuando e acenando a gradativa mudança de sua imagem no âmbito social:

Esta imagem de Teresa como subversiva logo foi 'esquecida' em 1590, com a publicação do jesuíta e seu ex-confessor Francisco de Ribeira[...]. Outro aspecto interessante nesta obra é o fato de ter sido escrito e reeditado por dois jesuítas, o Padre Ribeira em 1590 e o Padre Jaime Pons no ano de 1908. Por esta razão ao final desta publicação Jaime Pons anexa comentários acerca da monja carmelita com a companhia de Jesus, escrevendo sobre 'o amor constante y jamás interrumpido de Santa Teresa a la Compañia de Jesús ${ }^{93}$.

Com a entrada da defesa por parte dos jesuítas em prol da monja que lhes foi tão grata, dado a relação entre a Companhia de Jesus e Teresa ser sempre muito estreita, agilizou-se seu processo de beatificação e canonização. Além da obra de Ribeira, outros livros, poemas, justas literárias e teatrais, tinham como alvo a Teresa de Jesus. Nelas, são elucidativas as histórias do dramaturgo Lope de Vega, que escreveu, na época dos festejos de sua beatificação e canonização, pelo menos duas obras dramáticas, onde Teresa é a protagonista. Lope de Vega apresenta-a em suas comédias como uma jovem de espírito livre, atraída por coisas mundanas, que se converte lendo as 'Confissões de Santo Agostinho'. O autor ressalta a luta de Teresa com o diabo, ao invés das suas experiências místicas ${ }^{94}$. Os centenários de Teresa também foram significativos para demostrar o autêntico reconhecimento da Igreja e da sociedade e da história, para com ela.

\footnotetext{
${ }^{92}$ SANTOS, L. L. Fémina Inquieta y Andariega... p. 27.

${ }^{93}$ Ibidem. p. 31.

${ }^{94}$ Cf. SANTOS, L. L. Fémina Inquieta ... p. 33.
} 


\subsection{2}

\section{Fé e ousadia permanecem na história}

A audácia e a ousadia são características teresianas para hoje. Respondem ao mundo que nos cerca e conclamam a ser "amigos fortes de Deus" nos tempos difíceis do Brasil e da América Latina. Não são contrárias à experiência interior da gratuidade de Deus, antes a atualizam e historicizam, sendo ao mesmo tempo por ela dinamizadas ${ }^{95}$.

$\mathrm{Na}$ celebração dos quinhentos anos do nascimento de Teresa, lauream-se os quinhentos anos da fé e da coragem de uma mística que permanece na linha do tempo através da sua obra, presença, da sua força no poder da oração e na unidade com Cristo. Homens e mulheres, confiantes naquilo que Teresa acreditou e, à exemplo de Seu Mestre, encorajam-se a se dar, também, por inteiro, à missão.

À missão de amar. E que amor é esse que faz com que Teresa receba até mesmo o dardo do anjo em seu coração? É o que lhe submerge das profundezas, na simbologia da plenitude da sua capacidade de amar. É o que demonstra o quanto estava ela plenamente envolvida no amor ágape ${ }^{96}$, como ilustrado na obra de Gian Lorenzo Bernini, através dO êxtase de Santa Teresa ${ }^{97}$. É da imersão no amor que lhe vem a força de amar e o tesouro da sua doutrina, que encantou a tantas pessoas, ao longo destes quinhentos anos. Sim, não há como não perceber que há uma força maior a mover Teresa. Na Igreja a fé atribui essa força à ação do Espírito Santo. Somente na graça a pessoa é capaz de amar intensamente e de permanecer tranquila diante das controvérsias e maldades humanas, como nas provações que Teresa passou. Nota-se, que ao mesmo tempo em que de um lado é acusada de doutrina nova, supersticiosa, enganosa, semelhante aos alumbrados de Extremadura, por outro, por religiosos(as) e leigos da época é animada, exaltada. De sua parte, entre isso e aquilo, segue serena reafirmando às Irmãs e em seus escritos que "humildade é: andar na verdade" ", na verdade de Deus e na

\footnotetext{
${ }^{95}$ PEDROSA-PADUA, L. Espiritualidade integradora... p. 188.

${ }^{96}$ Cf. V 29.

${ }^{97}$ Para ler o êxtase descrito por Teresa, veja-se (V29). A obra de Bernini compreende os principais campos de escultura do momento: religioso, mitológico, sepulcral, em caráter barroco[...] Em termos de escultura religiosa, suas obras chegaram ao nível mais elevado. O "êxtase de Santa Teresa" é uma parte central de uma escultura em mármore concebida para a capela de Santa Maria della Vittória, em Roma. É uma das obras primas de Bernini [...] realizada no pontificado de Inocêncio I. Cf. PIRES, R. E. Erotismo e religião: um diálogo instigante. Rev. bras. Psicanál. São Paulo, v. 41, n. 2, jun. 2007. Disponível em http://pepsic.bvsalud.org/scielo. php?script=sci_arttext \&pid=S0486-641X2007000200013\&lng=pt\&nrm=iso $>$. Acessado em 18 maio 2012, às $15 \mathrm{~h} 10 \mathrm{~min}$.

${ }_{98}^{6} 6 \mathrm{M} 10,7$.
} 
nossa própria verdade ${ }^{99}$. E esta se conquista na paz da união e da intimidade com Cristo.

A violência da conquista foi sempre lastimada por Teresa, pois trazia a morte de tantos. E, quando ela mesma torna-se vítima do preconceito social, não consente. A própria organização de suas comunidades, a força da sua palavra e da sua vida, que encarnavam o amor, em si mesmas, denunciavam a inautenticidade contida na estrutura política e religiosa de seu tempo, particularmente, quanto à questão dos judeus conversos. Sabe Teresa que o humano não precisa ser assim e seu desejo é de que as pessoas pudessem simplesmente ser acolhidas, pois simplesmente são filhas de Deus.

A tradição e a cultura espanhola são também valorizadas por Teresa. Se precisa calar, o faz, no entanto em breve dará um jeito para deixar sua mensagem de outro modo. Assim, Teresa fica no imaginário coletivo de seus seguidores, com suas expressões, ensinamentos humanos, pedagógicos e sociais. Por estar muito adiante de seu tempo, ultrapassa a história, alcançando a época atual. Talvez a melhor chave de leitura para a compreensão de sua coragem, de sua confiança e de suas aventuras encontra-se na frase de Frei Maximiliano Herraiz, quando expressa que: notadamente, Teresa era uma mulher aberta, de uma afetividade forte, que "se sentia amada e amava intensamente"100.

\subsection{3}

\section{Uma mulher para o tempo atual}

Viu-se acima que Teresa, muito adiante do que se podia imaginar para uma mulher do seu tempo, tem sua atualidade crescente em nossos dias. Seus escritos caracterizados por este entrelaçamento da experiência vivida e convicções doutrinais, sua dupla experiência de vida humana e de mistério cristão são passos largos a uma prolongada e densa lição prática ${ }^{101}$. Em sua "retórica tipicamente feminina", serve-se de estratégias peculiares que são:

uma série de determinações de sua época, com as quais Teresa soube lidar, ora aceitando, ora contrariando. Suas obras constituem uma resposta a estas pressões sofridas, principalmente pela escritora ter feito algumas coisas que às mulheres não era permitido na Espanha do século XVI. Esta é a tese de Alison

\footnotetext{
${ }^{99}$ Cf. PEDROSA-PADUA, L. Espiritualidade integradora... p. 184.

${ }^{100}$ HERRAIZ GARCIA, M. Santa Teresa de Ávila... Acessado em 06 de maio de 2012, às $18 \mathrm{~h}$.

${ }^{101}$ Cf. ALVAREZ, T. Comentarios a las Obras... p. 5.
} 
Weber, sobre a retórica de Teresa de Jesus ao escrever suas obras: a monja carmelita teria utilizado uma 'retórica da feminilidade', uma espécie de estratégia narrativa, que explorava certos estereótipos da época sobre as mulheres ${ }^{102}$.

Percebe-se que ciente de sua condição feminina, a santa integra múltiplas vivências e serve-se dos mais diversos recursos. Seus dons naturais: inteligência, sagacidade, humor e ironia, são usados com o objetivo, de abrir portas para a vida. É o que se pode ver, por exemplo, no caso da designação dela própria como 'mulherzinha' (no original: mujercilla). Segundo a autora o termo 'mujercilla' era muito usado de modo pejorativo nos processos da inquisição espanhola, designando 'mulheres iletradas', ou hereges:

'Mujercilla' seria utilizado desta forma pela escritora não em um sentido de autodepreciação, mas como a utilização de uma 'retórica de ironia', já que as 'mulherzinhas' da época eram as chamadas subversivas pelos padres do Santo Ofício e, afinal, a uma 'mulherzinha como ela não eram permitidos a escrita de tratados de oração, nem o comando de fundações de conventos masculinos, como ela de fato o fez ${ }^{103}$.

Teresa não se dá por vencida, ocupa seu lugar de mulher, dando palpites e acrescentando vida à teologia escolástica de seu tempo que valorizava a cristandade, não a mística. Que oferecia a Bíblia aos clérigos, mas não à mão de religiosos e leigos, julgando que não consiguiriam compreendê-la, ou a interpretariam mal ${ }^{104}$. E, ali, onde tudo é motivo para desconfiar-se das mulheres, auto se denomina: Filha da Igreja. Ou seja, tem consciência do seu papel e do cumprimento de sua missão, enquanto cristã, orientadora, religiosa, mulher. Com o reconhecimento recebido de Mãe e Mestra de vida espiritual e mãe dos espirituais, a Igreja reafirmará nela seu valor, sua dignidade, sua capacidade de ser exemplo para o mundo inteiro, aos novos tempos ${ }^{105}$. E, assim é que também torna-se referência para as mulheres do novo Milênio que avançam em seus posicionamentos e reflexões em busca de novas posições na sociedade. Pois como acrescenta Mary Wollstonecraft às palavras de Hans Küng: “já é tempo de efetuar

\footnotetext{
${ }^{102}$ SANTOS, L. L. Fémina Inquieta ... p. 39-40.

${ }^{103}$ Idem.

104 Nessa época o sentir eclesial do Vaticano II, não havia sido despertado para a "vocação universal à santidade na Igreja" (LG,5), por isso o exercício da oração pessoal reservava-se ao clero esclarecido e era proibido às mulheres, leigos casados, ou analfabetos, dado pressupor apropriação pessoal da Palavra de Deus e liberdade interior. Nestes, fugiria ao controle do poder eclesiástico. Por isso se receava e punia. Cf. PEDROSA-PADUA, L. Espiritualidade ... p. 185.

105 Antes que a Igreja lhe tivesse outorgado oficialmente[...] o título de "Doutora", Teresa era reconhecida por todos como "mestra da vida espiritual e mãe dos espirituais". SCIADINI, P. Santa Teresa de A a Z. São Paulo: Loyola, 2004. p. 11.
} 
uma revolução nos modos das mulheres, já tempo de devolver-lhes a dignidade perdida e de fazê-las trabalhar, como parte da espécie humana", "para reformar o

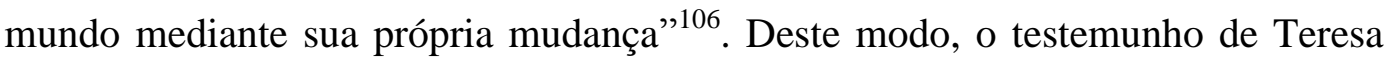
outorga-lhe ser esta autoridade que é. Sua luta, profecia, obra, testemunho de vida e expressões, são significados fortes à mulher pós-moderna que aspira fortalecer sua dignidade e ser profeta de um novo tempo. Semelhante à Teresa, a mulher cristã do século XXI, também será mística, no sentido de Rahner e renascerá nas fontes da água da vida de seu castelo interior, donde, recordará e celebrará o Cristo "vivo, entre nós". Assim, saberá anunciar e denunciar com a própria existência, roupagens velhas de arcaicas estruturas que já não fazem sentido, em prol de roupagens que comportam a essência mais profunda, saboreada pela Presença, pelo dom de Si Mesmo de Deus, acolhido entre os irmãos numa saudável inter-relação em vista de um mundo melhor, mais justo, solidário e humano.

\section{4 \\ CONCLUSÃO}

O primeiro capítulo dá uma noção geral a respeito da vida e obra de Teresa, compreendendo-a em seu contexto histórico e sócio-eclesial. Século de ouro, auge do poderio da Espanha, dirigida por homens influentes e armados, norteados por rigorosos estatutos de limpeza de sangue que prejudicavam a mouros e judeus. A Igreja, marcadamente masculina, fazia-se ouvir pela força, austeridade, guerras, pelo poder do Índex e da Inquisição. A cristandade extinguia-se. Há grandes e intensas reformas na sociedade: Lutero, Concílio de Trento, nascimento de grandes personalidades espirituais, sede por maior integração entre a vida e a fé. Nesse contexto de realidade, busca-se a ascensão em todos os aspectos da vida, contudo, de forma fragmentada, pois homens outorgavam-se o direito de serem juízes do mundo. Embora, na grande maioria das vezes, a mulher fosse a maior protagonista por fazer a vida andar, nessa época precisava seguir oculta, discriminada e, frequentemente era taxada de mulherzinha, como rotularam a

${ }^{106}$ WOLLSTONECRAFT, M. Apud MIRANDA, A. R. Mary Wollstonecraft e a reflexão sobre os limites do pensamento liberal e democrático a respeito dos direitos femininos (1759-1797). Dissertação (Mestrado). Curitiba: Universidade Federal do Paraná, Departamento de Letras. 2010. p. 77 . 
Teresa. Ao imaginário coletivo feminino, a sociedade desse tempo incutia ser adequado à mulher ficar limitada, em condição inferior, ou de assujeitamento ao homem, ou que era normal, ser desvalorizada e despossada de seus pensamentos, sonhos e ideais. Nessa cultura que não delega espaço, ficam sem voz ativa na Igreja e no mundo, sem direitos, sem a possibilidade de ocupar posições significativas na participação política, democrática e social. O desejo de evolução desta sociedade que, por inteira, quer transformar-se, é limitado, pois não consegue reconhecer a identidade peculiar, nem legitimar a libertação feminina.

Entretanto, enquanto a maioria das mulheres de seu tempo se cala, aceitando a condição na qual lhe colocam e, prefere acomodar-se para sobreviver, para não pagar alto preço de sofrimento à crítica, ao desafio da ridicularização, exclusão, ou preconceito Teresa não se omite. Vai além. Fala por sua voz e com sua vida. Por isso sofre perseguições. Contudo, a partir delas adquire um nível de consciência que a faz estar adiante do seu tempo. Ocupa lugares antes jamais delegados às mulheres, na história da humanidade. Na conquista destes espaços faz-se respeitar não pela força, mas justamente pelo investimento na sua condição de mulher e pela seriedade daquilo a que se propôs.

Primeira doutora da Igreja. Primeira mulher a realizar a fundação de conventos de homens e a dirigir padres e religiosos. Com dezessete conventos fundados, torna-se a reformadora de uma Ordem com dois ramos: masculino e feminino. Seus posicionamentos, sua empatia no diálogo e na inter-relação ultrapassam dogmatismos e barreiras. Acredita em si, na fortaleza de sua feminilidade, no seu potencial enquanto humana e cristã. Mostra com sua vida, como as mulheres de seu tempo e, hoje, as pós-modernas, podem usar de sua feminilidade e da força do amor na conquista de novos ideais e novas posições na sociedade. Ao gerar novos e criativos espaços de se ir ao encontro de si mesma, de Deus, das irmãs e dos irmãos reafirma o ideal da nova mulher e da força da mística. Nesse ideal vai ao encontro de homens e mulheres que se colocam a serviço de Deus na busca da verdade. Sua a luta é por uma sociedade que avança na fé, na ciência e na cultura, visando um novo rosto social e eclesial construído na solidariedade de quem está consciente que nasce para Deus e para os irmãos. $\mathrm{Na}$ utopia desta nova mulher e deste novo homem, que se experimentam na força da mística, haverá ânimo para se realizar grandes coisas, em prol de um humano mais íntegro, relacional, saudável, como possível foi possível à Teresa. 


\section{A MÍSTICA CRISTÃ}

\section{1}

\section{Introdução}

O capítulo está dividido em duas partes (2.2 e 2.3). A primeira parte visa à explicitação dos conceitos de mística usados na tese, termos a ela relacionados, necessidade da integração entre eles. Conceitua a mística cristã articulando a gradativa inserção do homem e da mulher de fé no Mistério de Cristo, caracteriza a evolução da ciência e a intrínseca ligação entre a fé e a vida/política. A segunda parte situa a problemática da ciência e da mística na história e na atualidade, mostra como se encontra hoje em vias de superação a ideia da adversidade, com razões para a complementação e não predomínio de uma em detrimento da outra.

\section{2 \\ Conceitualizações}

Neste ponto seguem-se as explicitações de diferentes conceitos: de mística cristã, expressões relacionadas à mística, fenômenos místicos, fenômenos extraordinários, fenômenos psicológicos e conceito de mística teresiana.

\subsection{1}

\section{Conceito de Mística Cristã}

Que têm hoje a dizer-nos estes místicos [...]? Qual pode ser sua mensagem aos cristãos[...] que procuram realizar sua fé no meio de dramáticos desafios? Qual pode ser sua importância na Teologia[...] na luta pela justiça e [...] direitos humanos, na busca de reconciliação e comunhão[...]? Que mensagem oferecem a uma Igreja que quer renovar-se para melhor realizar sua missão de evangelização no presente e no futuro[...] ? $^{107}$

A palavra mística entrou no cenário do cotidiano e acabou ficando bastante usual nestes últimos tempos. Usa-se a terminação de forma adequada, inadequada, de forma intensa, exacerbada, ou até mesmo com um sentido totalmente adverso

107 GALILEA, S. As raízes da espiritualidade latino-americana: os místicos ibéricos. Tradução Luiz João Gaio; revisão Eliane Henrique Nunes Farias. São Paulo: Paulinas, 1984. p. 24. 
do de sua proveniência. Tanto que Henrique de Lima Vaz afirma que o termo chega a esvaziar-se de seu sentido primeiro, pois

Decaído de sua nobre significação original acabou por designar uma espécie de fanatismo, com forte conteúdo passional e larga dose de irracionalidade. Assim o vemos nas expressões "mística do partido político", "mística do clube esportivo" e em outras semelhantes. Essas expressões seriam inocentes e não representariam mais do que impropriedades de linguagem se a elas não estivesse subjacente uma inversão profunda da ordem que deve reinar em nossa atividade psíquica e espiritual ${ }^{108}$.

Todavia, indo às fontes de sua significação vê-se que, em sua origem, a palavra mística fala de uma realidade vivida pelo ser humano desde seus primórdios e, não obstante a distância do tempo, comporta em sua essência prima, ainda para hoje, um significado admirável que elucida e sustenta o que se compreende dela na Teologia e no cristianismo. Assim, do ponto de vista dos místicos e de seus estudiosos, geralmente e, já de longa data, usa-se essa expressão para significar a experiência do encontro com a realidade transcendente.

$\mathrm{Na}$ palavra mística aparecem dois aspectos importantes: o aspecto do mistério, objetivo numa primeira instância e o aspecto da experiência, subjetivo e experiencial, numa instância posterior. Segundo Henrique de Lima Vaz, a consideração do aspecto de mistério cabe particularmente para a mística cristã que "herdou da tradição grega uma estrutura conceptual e nela transfundiu um espírito novo, vindo a surgir daí um modelo, ou modelos, da experiência mística, profundamente originais" ${ }^{109}$. Deste modo, sua singularidade, contida no decurso da tradição, alude à expressão mística traduzida, ao longo da história, como referência ao mistério, algo oculto nos ritos, nos mitos, nos símbolos e acessível às pessoas aptas a assimilá-lo. Do mesmo modo, em Rudolfo Otto, pode-se ver que o sentido literal e original da palavra encontra-se, justamente, nesta derivação:

"Mistérios, Mystes e mística, provavelmente derivam de um radical ainda preservado no sânscrito Mus. Mus significa "agir às ocultas, secretamente"[...]. Mistério de um modo geral significa inicialmente apenas enigma no sentido de estranho, não compreendido, inexplicado; nesse sentido, mysterium é apenas uma analogia oriunda do meio natural, para aquilo que nos referimos, uma analogia que não esgota o termo em si. Este porém, o termo religioso o mirum autêntico é (possivelmente em sua melhor formulação): "o totalmente Outro", o thãterón, o anyad, o alienum, o aliud valde, o estranho e o que causa

${ }^{108}$ VAZ, H. C. L. Experiência mística e Filosofia na tradição ocidental. São Paulo: Loyola, 2000. p. 9.

${ }^{109}$ Idem. p. 29. 
estranheza, que foge do usual entendido e familiar, contrasta com ele, por isso, causando pasmo estarrecido" $" 110$.

Do ponto de vista da experiência, o místico por se encontrar frente a frente com o Mistério, com o Totalmente Outro, se torna uma pessoa sensível, que assimila de forma intensa realidades transcendentes e imanentes que podem passar despercebidas ao olhar da grande maioria das pessoas. Estas características possibilitam compreender o quanto:

[...] o sentido original e que vigorou por longo tempo, do termo mística e de seus derivados diz respeito a uma forma superior de experiência, de natureza religiosa[...]que se de desenrola normalmente num plano transracional, não aquém, mas além da razão[...] (que), por outro lado, mobiliza as mais poderosas energias psíquicas do indivíduo[...] essas energias elevam o ser humano às mais altas formas de conhecimento e de amor que lhe é dado alcançar nesta vida ${ }^{111}$.

Contudo, essa experiência, por sua natureza religiosa, considerada por Lima Vaz como superior, delineia-se, assim, antes de tudo, pela gratuidade do transcendente que se dá e que, ao mesmo tempo, oferece seus dons no encontro com a pessoa, independente da grandiosidade, ou visibilidade dos efeitos (dos fenômenos místicos) que a autêntica espiritualidade pode, ou não, deixar ${ }^{12}$. Compreende-se, então, este relacionamento entre o Mistério e o místico, como troca de doação e de amor, de ambas as partes. Ou seja, uma comunicação da parte de Deus que, singularmente, Ele faz doando-se a Si Mesmo, com a plenitude de vida que quer comunicar, que será acolhida na simplicidade daquele que vive cotidianamente aquilo que crê. Assim, na ótica da fé cristã, este mistério, escondido em Deus, está mediado e revelado pela pessoa de Jesus Cristo, respeita a natureza humana e, ao mesmo tempo a modifica ${ }^{113}$. Desta forma, o mais evangélico, o entranhado, o genuíno sentido da mística transparecerá na pessoa e no desenvolvimento da sua natureza antropológica, quando o ser humano, ao vivenciar sua fé, integra nela todas as dimensões de sua vida, não somente a religiosa, mas também a dimensão corpórea, social, política, etc.

Esta visão de integração das diferentes dimensões da vida ultrapassa a visão platônica e dualista de corpo e alma/espírito e de sagrado e profano, que perdurou

\footnotetext{
${ }^{110}$ OTTO, R. O Sagrado: os aspectos irracionais na noção do divino e sua relação com o racional. Tradução de Walter O. Schlupp. São Leopoldo: Sinodal/EST; Petrópolis: Vozes, 2007. p. 58.

${ }^{111}$ VAZ, H. C. L. Experiência mística ... p. 9.

${ }^{112}$ Cf. MACCISE, C. Mística na Revelação bíblica. In: BORRIELLO, L. et. al. Dicionário de Mística. São Paulo: Paulus/Loyola, 2003. p. 737.

${ }^{113}$ Cf. BOFF, L; FREI BETO. Mística e espiritualidade. 6. ed. Rio de Janeiro: Garamond, 2005. p. 76.
} 
muito tempo na sociedade ${ }^{114}$. Perspectiva esta, que fez com que na Igreja e, entre os cristãos, particularmente os da vida religiosa e monástica, se tivesse o pensamento de que era a alma que se encontrava com Deus, enquanto o corpo havia de ser macerado para alcançar maior evolução espiritual. Assim, tanto quanto possível, devia ter-se um afastamento social, para se ter um efetivo encontro com o transcendente ${ }^{115}$. Através deste modo, de se compreender e de se proceder, julgava-se que o fiel podia estar, ou se sentir, mais próximo de Deus. Acreditava-se, de igual forma que no meio do povo e do barulho não era possível a contemplação. Desta forma e nesta ótica, quanto mais distanciado dos problemas e da realidade do mundo, tanto maior seria a perfeição na entrega e no amor à Deus. Contexto com o qual tornavava-se impossível perceber a ligação entre a fé e a política, entre o amor a Deus e amor ao próximo.

É verdade, uma certa compreensão da mística é incompatível com um certo modo de se fazer política. A vida religiosa está imbuída deste conceito de que contemplativo é quem dá as costas ao mundo para postar-se diante de Deus. Todavia não é bem no Evangelho que se encontram as raízes desse modo de testemunhar o absoluto de Deus, mas sim em antigas religiões pré-cristãs e nas escolas filosóficas gregas e romanas, que proclamavam a dualidade entre alma e corpo, natural e sobrenatural, sagrado e profano. O monaquismo que nasce no século IV como afirmação da fidelidade evangélica[...] não teve alternativa histórica senão nutrir-se na ideologia em voga: o platonismo ${ }^{116}$.

Como resultado dessa fragmentação histórica entre a espiritualidade e a prática da vida, despontava-se um individualismo cada vez maior que não só distanciava as pessoas, mas, auxiliava a se tonificar os conceitos de meditação, santidade e de perdição, num modo dual de se viver e se relacionar com Deus.

As muitas transformações que a humanidade foi passando neste tempo devem-se ao advento do Mundo Moderno ${ }^{117}$ e à transição deste para o Pós-

${ }^{114}$ A visão platônica remonta a Platão e à sua origem de mundo, retomada depois por Plotino e aperfeiçoada amplamente por Agostinho[...] foi posta em crise no século XII, com a entrada de Aristóteles no ocidente, mas teve fragmentos de suas ideias até há pouco na Igreja. Cf. BOVE, G. Iluminação. In: MANCUSO, V.; PACOMIO, L. (Orgs.). Lexicon: Dicionário Teológico Enciclopédico. Tradução: João Paixão Neto e Alda da Anunciação Machado. São Paulo: Loyola, 2003. p. 374.

${ }^{115}$ Basta lembrar os famosos tempos da fuga mundi. Contudo, “... a Igreja nunca se compreendeu e se realizou prescindindo do respectivo contexto histórico”. FRANÇA MIRANDA, M. A Igreja numa sociedade fragmentada... p. 179.

${ }^{116}$ FREI BETTO. Prefácio. In: BOFF, L.; FREI BETO. Mística e espiritualidade. 6. ed. Rio de Janeiro: Garamond, 2005. p. 15.

${ }^{117}$ Para entender o modernismo [...] que culminará no secularismo é necessário perceber que "A modernidade é um processo que tem sua origem no século XVI, quando começa a emergir um novo tipo de humanidade consciente de sua própria autonomia e de sua própria força racional... a razão começa a celebrar o seu triunfo, empurrando a fé sempre mais para a periferia. Esta 
Moderno $^{118}$, especialmente ao período da crise da razão, onde se mudou qualitativamente o modo de pensar humano. Com isso, mudaram-se os conceitos, mudou-se o modo de agir, de viver ${ }^{119}$. De modo que, na contextura dessas mudanças pode se pensar, se redescobrir, um novo conceito antropológico a partir do qual se podia entrever, uma melhor compreensão da relação do humano com o Sagrado. Essa virada foi fundamental à história e trouxe ao cristianismo uma verdadeira revolução que influenciou de modo peculiar o conceito de mística, auxiliando-a a resgatar sua essência e a procurar a comunhão de vida, com o Deus da Vida e do Amor. Nesse sentido, continua Frei Betto, foi que

A ideia de uma natureza humana conflitantemente dividida entre carne e espírito representou para a espiritualidade cristã, o que a cosmologia de Ptolomeu significou antes das teorias científicas de Copérnico e Galileu, (que) quem se dedica às coisas do mundo, à polis, arrisca-se à perdição. A santidade era concebida como negação da matéria, mortificação da carne, renúncia da vontade própria, fruição de êxtase espiritual. Nessa ótica atomística de se compreender a relação da pessoa com a divindade, havia acentuada dose de solipsismo: o cuidado do aprimoramento espiritual do eu sobrepunha-se à exigência evangélica de amor aos outros ${ }^{120}$.

Ou seja, a antiga concepção platônica, por melhor que pudesse parecer ao seu tempo, com sua visão estanque, seccionava o dinamismo da fé e estagnava a aventura espiritual do encontro com Deus e da prática do amor fraterno em meio ao cotidiano das pessoas. Horizonte, hoje, inadmissível!

Para Leonardo Boff e Frei Betto, esta redimensão antropológica possibilita ao fiel contemporâneo compreender a mística mais inteiramente como derivação de mistério. Desta forma, é possível entender o próprio mistério não mais como limite do conhecimento, mas ao contrário, como o ilimitado do conhecimento e, assim, pode-se conhecer sempre mais e mais. Deste modo e, de acordo com estes

autonomia do ser humano recebe novo impulso a partir do século XVIII... e desemboca na sociedade que denominamos 'secularizada'... O que conta na vida do ser humano é este mundo, é a imanência. A transcendência nada mais diz ao homem da modernidade. É o fenômeno do 'secularismo"'. RAMPAZZO, L. Antropologia, Religiões e Valores cristãos. 3. ed. São Paulo: Loyola, 2004. p. 159-160.

118 Para maiores detalhes da mística na pós-Modernidade pode-se ler: VANZAN, P. Dessecularização-Ressacralização. In: BORRIELLO, L. et. al. Dicionário de Mística. São Paulo: Loyola/Paulus, 2003. p. 320.

119 Sobre a mística na modernidade e na pós-modernidade, pode-se complementar: OLIVEIRA, J. L. M. Viver os votos em tempos de Pós-Modernidade. 2. ed. Rio de Janeiro: Loyola, 2002; LIBANIO, J. B. Jovens em tempos de Pós Modernidade: considerações sócio-culturais e pastorais. São Paulo: Loyola, 2004; SCIADINI, P. Mística e Compromisso: Pistas para dias de deserto. São Paulo: Loyola, 1989; SCHIAVO, L. Mística e Pós-Modernidade: Culturas, Sociedade e religião. Goiás: UCG, 2005.

${ }^{120}$ FREI BETTO. Prefácio. In: BOFF, L.; FREI BETO. Mística e espiritualidade... p. 15. 
autores, o exercício da mística suprime a necessidade de abstrair-se do corpo para se relacionar com o transcendente passando a se valorizar ainda mais o corpo nesta íntima integração (corpo, mente, alma), dado que o corpo é fundamentalmente necessário para ir-se ao encontro do corpóreo, do material. Assim, vê-se que a mística tem a finalidade de auxiliar o humano a entrar em diálogo, em comunhão, cada vez mais profunda com o Mistério que se encontra na realidade que o cerca e, a partir deste lugar, permitir ao fiel fazer a experiência do próprio mistério, com todo o seu ser.

Nesta relação é que o Boff conceitua a mística, considerando, tudo como mistério: Deus, a Bíblia, a natureza, as pessoas, o coração de cada um e o universo inteiro. De maneira que para o autor em questão, a mística não é outra coisa senão: a capacidade de poder se relacionar com o mistério, estando com os olhos abertos e as mãos operosas no chão da realidade na qual se vive ${ }^{121}$, experimentando-O em tudo e em todos os momentos.

Ora, exatamente isso é a mística: experimentar Deus. Experimentar Deus em todo o ser e senti-lo no coração. Dialogar com ele, chorar diante dele, alegrar-se nele, confiar a Ele a vida e o destino e mergulhar em seu mistério. Uma coisa é pensar Deus. Aí ele está apenas em nossa cabeça, numa parte de nosso ser. Outra coisa é sentir Deus em todo o ser. Então todos os lugares da pessoa são tomados por Deus: o corpo, a alma e o espírito ${ }^{122}$.

Para Frederico Ruiz Salvador, nessa nova ótica antropológica pode-se pensar a mística com maior interação, pois a compreensão anterior deixava a convicção de que:

Não se consegue a unidade pondo se o coração onde se pôs as mãos: (ora), se se trabalha para o bem temporal da humanidade, deve-se aplicar o amor aos bens temporais[...]. A unidade de vida como cristãos, requer a dedicação da existência a valores de salvação eterna. Então não há outra solução senão descobrir o valor eterno que Deus pôs na realidade temporal e no coração dos homens que a fomentam e a utilizam ${ }^{123}$.

Assim, dos conceitos acima explicitados, desprende-se num primeiro momento, o que aqui nesta tese se entende por mística. Em suma, mística é esta experiência humana que se inclina a olhar no mistério da existência, para além daquilo que se vê, para a realidade que envolve a pessoa num todo e que é mais

${ }^{121}$ Cf. BOFF, L. O visível e o invisível. In: BOFF, L.; FREI BETO. Mística e espiritualidade... p. 27.

122 Idem.

123 RUIZ SALVADOR, F. Compêndio de Teologia Espiritual. Título original: Caminos del espíritu. Revisão Célia Regina Faria Menin; Sandra Garcia. São Paulo: Loyola. 1996. p. 222. 
ampla e mais profunda do que o que se visualiza, ou se pode entender apenas através da razão. Deste modo, mística é encontrar-se com o Mistério. Na mística cristã crê-se que este Mistério se revela na criação, na pessoa de Cristo, na Igreja, na comunidade e em cada pessoa "nos textos da Sagrada Escritura e na liturgia que por essa razão adquirem um sentido místico, geralmente por referência a Cristo e à Igreja" ${ }^{\prime 124}$. O encontro com este Mistério anima cada um a tocar o mistério da vida e a ir ao encontro do mistério dos outros seres humanos, seus irmãos e, junto com eles, munir-se da capacidade e da fortaleza para transformar a realidade do mistério no qual se vive, sem perder o olhar em direção a um Mistério ainda maior.

\subsection{2}

\section{Expressões relacionadas à mística}

O modo cristão de ver a realidade procurou um equilíbrio entre o desejo de falar de Deus e a necessidade de reconhecer que Deus, em última análise, está para além de tudo o que podemos dizer. A melhor expressão deste aspecto elusivo de Deus está nas tradições de misticismo e espiritualidade ${ }^{125}$.

Ligada à expressão mística (entendendo aqui a mística religiosa), encontram-se outras expressões, como Religião, Teologia, ou Espiritualidade, que se acercam do tema escolhido nesta tese e que, na linguagem cotidiana muitas vezes chegam, inclusive, a ser usadas como sinônimos. No entanto, há nelas características, nuances específicas que, para os que aprofundam a temática, faz sentido discernir. Assim, segundo Hans Küng, por religião se compreende

A realização socioindividual (em doutrina, costume, frequentemente ritos) de uma relação do homem com algo que o transcende e a seu mundo, ou que abrange todo o mundo, que se desdobra dentro de uma tradição e de uma comunidade. É a realização de uma relação do homem com uma realidade verdadeira e suprema, seja ela compreendida da maneira que for (Deus, o absoluto, Nirvana, Shûnyatâ, Tao) ${ }^{126}$.

Entende-se, que todas e cada uma das religiões que existe, tem a sua própria mística, sua própria espiritualidade, sua própria doutrina, seus próprios ensinamentos e é "a religião (que) formaliza e socializa a experiência de fé de

\footnotetext{
${ }^{124}$ Ibidem. p. 502.

${ }^{125}$ SHELDRAKE, P. Espiritualidade e Teologia... p. 49.

${ }^{126}$ KÜNG, H. Religiosidade, espiritualidade, mística... p. 91.
} 
cada grupo" ${ }^{127}$. Assim, a Religião ${ }^{128}$ encarrega-se de ensinar e mostrar ao ser humano a mística como caminho para se relacionar com Aquele que o transcende.

Neste caminho, para onde a pessoa se orienta, em direção ao transcendental, há uma reivindicação interior. Há uma exigência implícita à sua disponibilidade de caminhar, que nasce com questionamentos e firma-se no desejo do peregrino de conhecer melhor a realidade que está além de si mesmo. Uma exigência envolta na curiosidade de saber como o seu transcendente o percebe, ou de analisar como se relaciona com ele, de entender seu próprio movimento em direção à Deus e o que acontece nessa relação, na vida.

Ora, a necessidade de compreender as razões de sua fé, servindo-se de todos os recursos para a explicitação dessas questões, chama-se: Teologia ${ }^{129}$. Algo tão simples de entender, como João Mohama o expressa:

Teologia é a ciência que estuda Deus. A ciência que estuda como Deus é, como Deus age, como Ele existe, como Ele pensa o que pensa, o que quer, o que deseja, etc. Eis o que é Teologia. Estudo de qualquer problema referente a Deus e também da relação que possuem com Deus todas as realidades, visíveis e invisíveis, íntimas e públicas, celestes e terrestres. Assim, o estudo da opinião de Deus a respeito da educação é Teologia da educação; da política, é Teologia da política; da economia, é Teologia da economia; da arte, é Teologia da arte; da sexualidade é Teologia da sexualidade ${ }^{130}$.

De modo que Teologia é a ciência que aborda, efetivamente, as explicações para todas as realidades da vida, na relação do ser humano com seu Deus. Ciência? Sim, compreende-se Teologia como ciência e no rol, entre outras ciências. Contudo, é bem importante perceber que o próprio conceito de ciência modificou-se ao longo da história enquadrando-se dentro das características de

${ }^{127}$ Cf. ARAGÃO, G. Inculturação da fé cristã na religiosidade popular. Vida Pastoral. São Paulo: Paulus, 2013. ano 54. março-abril. n. 289. p. $7 .$.

${ }^{128}$ A religião remete a um significado profundo na história da humanidade, uma vez que desde seus princípios e, através de inúmeras manifestações culturais, simbolizava a necessidade de comunicação com um Ser Superior. Basta ver os ícones, imagens, que levavam já o homem das cavernas a ligar-se com seu transcendente. Através destes meios e desta busca que "a Religião indica o caminho da razão, da experiência humana para ligar-se com o divino. Institui um sistema de ritos, práticas e doutrinas, constituições, tradições, organizações, mitos, artes que possibilitam essa religação com o mundo divino. Configura um sistema de representação, de orientação, de normatividade. Traduz uma realidade objetiva, uma tradição acumulada e vivida por uma comunidade. Mostra o lado visível da relação com o Sagrado". LIBANIO, J. B. A Religião no início do milênio. São Paulo: Loyola, 2002. p. 90.

${ }^{129}$ A definição clássica da Teologia "significa: compreensão da fé. Usar todas as forças e todos os recursos da razão humana para compreender o que Deus diz ao homem em sua revelação; esclarecer e aprofundar, à luz da fé tudo o que a razão conhece e procura conhecer em seu campo próprio: eis o empreendimento da razão sob o domínio da fé. Esse opus perfectum rationis... de um lado da fé, de outro da razão". TOMÁS DE AQUINO, S. Suma Teológica I. Tradução e direção Pe. Gabriel C. Galache. 2. ed. São Paulo: Loyola, 2001. p. 34.

${ }^{130}$ MOHANA, J. A vida sexual dos solteiros e dos casados. 3. ed. São Paulo: Loyola, 2002. p. 87. 
uma época. Assim, nota-se que, antes dos tempos modernos, a ciência conceituava-se de um modo distinto ao de hoje. Antes, pensava-se assim:

[Ciência é o] conhecimento certo e sempre válido, resultado da dedução lógica. Certo porque procede de evidências primeiras e indemonstráveis. Dedutivo porque articula as conclusões com os princípios universalmente válidos por meio de raciocínios necessários. Perfeito porque atinge as coisas em seus princípios essenciais e necessários. Por conseguinte, (a) ciência pretende conhecer de maneira certa, as causas, ou as razões de $\operatorname{ser}^{131}$.

Nesse modo de pensar, a Teologia firmava-se como ciência não pela verdade imediata de seus princípios, mas porque se encontrava subordinada à verdade de Deus. Ou seja, era considerada ciência porque se subordinava à ciência de Deus (verdade revelada). Neste contexto, os fundamentos da Teologia tornavam-se evidentes na ciência pela subordinação à verdade que se compreendia de Deus, de onde recebia os seus princípios. De modo que as verdades reveladas participavam da evidência divina pela revelação e pela fé ${ }^{132}$.

Com a chegada dos tempos modernos, mais precisamente com Copérnico, Galileu Galilei e Newton, entre tantas outras mudanças, mudou-se também o conceito de ciência, passando-se a entender ciência com a seguinte compreensão:

Os conhecimentos, que formam o corpo teórico das ciências, adquirem-se por meio de métodos muito precisos de experimentação, nos quais as afirmações se provam imediatamente, podem ser verificadas e por isso, admitidas universalmente, desde que se respeitem as condições do experimento. As ciências pretendem ter um controle de todas as proposições pela experimentação. Seus conhecimentos são elaborados e controlados por procedimentos de demonstração e verificação ${ }^{133}$.

Desta forma, é possível perceber que, na passagem de uma sociedade teocêntrica (Idade Média) para uma antropocêntrica (Renascimento), a inversão no modo de se conceber Deus e a ciência a ele dedicada, fez-se sentir sensivelmente ${ }^{134}$. Anteriormente havia um unicentrismo, depois, cada ciência se proclama independente. $\mathrm{E}$, se antes, todas as demais ciências mendigavam o beneplácito da Teologia, inclusive a ponto da Filosofia autodenominar-se como sua serva: ancilla theologiae, depois o que se viu foi o oposto: a Teologia se esforçando para ser ainda reconhecida, com certa dignidade, no consórcio das

${ }^{131}$ LIBANIO J. B; MURAD, A. Introdução à Teologia: perfil, enfoques, tarefas. São Paulo: Loyola, 1996. p. 80.

132 Idem.

${ }^{133}$ Ibidem... p. 81.

${ }^{134}$ Detalhes interessantes se deram na passagem de uma sociedade teocêntrica para uma sociedade antropológica, ver: NERY, M.C.R. Sociologia a Ciência da crise. IN: TESKE, O. (Coord). Sociologia: textos e contextos. Canoas: ULBRA, 1999. p. 39-40. 
ciências e, com grande esmero debatendo-se entre as demais para ser respeitada e levada a sério e não mais relegada ao mundo das fábulas ${ }^{135}$. Para Paul Gilbert é necessário perceber neste progresso científico que "não se pode julgar a ciência de uma época a partir da atual"136, a ciência, hoje, possui outra ótica e não se tem

[...] mais uma definição muito segura do que (seja) ciência. Alguns propõem este princípio[...] a ciência é[...] um discurso construído com base em algumas regras convencionais[...]. A distinção clássica entre objeto material e objeto formal entre aquilo de que se fala e o modo de se falar disso, fazia apenas com que a forma do discurso fosse derivada de sua matéria... Nesta perspectiva a ciência é principalmente uma forma de logos, determinada secundariamente, $a$ posteriori, pela sua matéria. Sua racionalidade regula sua definição ${ }^{137}$.

Nesta direção e acompanhando o desenvolvimento dos novos âmbitos da ciência, a Teologia vai desenvolvendo-se e se posicionando gradativamente. No enquadramento destas novas esferas científicas postula seu lugar e procura exibir um conjunto de conhecimentos ordenados, com objeto, método, unidade e sistematização próprios. Com isso, merece o direito ao título de ciência. Sem embargo, sabe-se que a ciência da fé sempre cumpriu e cumpre muito bem a determinadas funções da ciência, mas a outras não responde do mesmo modo. Desta forma é considerada ciência de maneira original, uma vez que o fenômeno do constatável, do verificável, ou a comprovação de suas verdades, por meio da experimentação, não corresponde à natureza teológica. Contudo, devido ao fato de no cenário da cientificidade se admitir diferentes métodos de se fazer ciência, pode se dizer que a Teologia atende às exigências do corpo científico, uma vez que aprofunda a natureza teológica a partir de seu objeto: o Mistério ${ }^{138}$.

Do ponto de vista teológico, este Mistério que se dá a Si Mesmo, por mais misterioso que seja Deus é e sempre será realidade, porque está sempre para além de toda a criatura, para além de toda a história ${ }^{139}$ e para além da ciência. Assim, consequentemente, entende-se por que:

a linguagem teológica não pode situar-se na ordem da objetividade expositiva. Não exprime sem mais, dado verificável, observável, descritível. Não expressa simples pensamento. Seu pressuposto último é uma atitude de fé diante da Palavra reveladora de Deus no interior de uma comunidade ${ }^{140}$.

\footnotetext{
${ }^{135}$ Cf. LIBANIO J. B.; MURAD, A. Introdução à Teologia... p. 81

${ }^{136}$ GILBERT, P.P. Introdução à Teologia medieval. São Paulo: Loyola, 1999. p. 25.

${ }^{137}$ Idem.

${ }^{138}$ Cf. LIBANIO J. B; MURAD, A. Introdução à Teologia... p. 84.

${ }^{139}$ Ibidem... p. 84-91.

${ }^{140}$ Ibidem... p. 91.
} 
Dando continuidade ao estudo das expressões, há outra palavra importante nesse cenário que alude ao envolvimento dual e à factibilidade da relação entre a pessoa e o Mistério, mas que, sobretudo, foca no movimento, que se dá a partir da fé daquele(a), que busca seu Ser Superior, no exercício da Religião, ou no exercício da Teologia: é a Espiritualidade.

$\mathrm{Na}$ dinâmica do fiel nesta busca do transcendente observa-se que a espiritualidade comporta dois objetivos específicos: a união com Aquele que é considerado o Ser Superior e a transformação pessoal, devido à aproximação e à conexão com Ele. No caso da espiritualidade cristã, acredita-se que esta transformação acontece em uma conversão, através da ação do Espírito Santo. Desta maneira:

A espiritualidade não é um estado, mas uma forma de viver a fé cristã a partir de um impulso da graça para participar da vida divina na peregrinação terrestre, pois a consumação só terá lugar quando Deus será tudo em todos $(1$ Cor 15, 28). A Vida nova do homem exige algo mais que uma descomprometida adesão intelectual a Deus. Requer uma adesão de todo seu ser, uma entrega total a Deus. O Evangelho possibilita uma transformação através da renúncia, obediência até a morte na cruz, ressurreição e elevação, esvaziando-se de si mesmo e enchendo-se de Jesus Cristo ${ }^{141}$.

Por se compreender a espiritualidade como essa forma de viver a fé cristã, numa adesão de todo o ser compreende-se que ela "se refere a todo o processo de crescimento, desde a inautenticidade à relação concreta com Deus e à posse de sua verdade" ${ }^{142}$. Contudo, antes de se descrever a natureza e os traços fundamentais da mística cristã é necessário distinguir a espiritualidade da experiência mística e perceber que esta última circunscreve-se no próprio estudo da espiritualidade, ou como denominam alguns: dentro da Teologia espiritual. Assim a espiritualidade

[...] trata da evolução existencial da vida segundo o espírito, (que é) experimentada pelo homem em caminho para a plenitude da comunhão com Deus. (Enquanto que na mística)[...] mais precisamente pretende refletir sobre este caminho espiritual em seu devir contínuo, segundo o desígnio particular de Deus, com o qual o cristão entrou em relação pessoal de amor ${ }^{143}$.

De maneira que todos os cristãos, em virtude do batismo, são chamados por Deus para viver a espiritualidade e crescer na relação com Ele. Há critérios

${ }^{141}$ ZILLES, U. Espiritualidade cristã. In: TEIXEIRA, E. F. B.; MÜLLER, M.C.; SILVA, J. D. T. (Orgs.). Espiritualidade e Qualidade de Vida. Porto Alegre: EDIPUCRS, 2004. (Coleção Filosofia, 11). p. 17.

${ }^{142}$ Cf. LARKIN, E. Espiritualidade. In: BORRIELLO, L. et. al. Dicionário de Mística... p. 381383.

${ }^{143}$ BORRIELLO, L. Experiência Mística. In: BORRIELLO, L. et. al. Dicionário de Mística... p. 403. 
fundamentais para perceber se há esse crescimento na vida da graça e, se a pessoa realmente está se desenvolvendo na relação pessoal de amor e de comunhão com Deus. Assim, naqueles que avançam e se desenvolvem através do exercício da espiritualidade, vê uma:

modalidade sempre mais pneumatizada do próprio ser, movido pelo Espírito: o abandono filial a Deus Pai no Espírito de Cristo e a vida de caridade movida segundo o Espírito de Cristo[...]. se toma em consideração a própria vida de Deus, participada em Cristo mediante o espírito ${ }^{144}$.

Particularizando-se a mística, pode-se dizer que ela é substancialmente a tomada de consciência dessa espiritualidade, dessa experiência do espírito vivida pelo fiel em seu íntimo, de modo que, em geral a espiritualidade:

trata mais propriamente do processo de interiorização do mistério cristão, isto é da revelação do Filho de Deus encarnado no âmbito da Igreja, cujas condições normais de crescimento são a vida de fé e a vida sacramental. Por isso, a espiritualidade é fruto da fé[...] vida da graça, tornada consciente, conhecida experientalmente $^{145}$.

Desta forma, a experiência da espiritualidade ao trazer a consciência do que acontece nessa relação, nesse dinamismo da comunicação com Deus evidenciando à pessoa "a consciência de sua vida em Deus e da vida de Deus nela", 146 , torna-se mística. Que é uma consciência que se desenvolve pouco a pouco e acolhe

o sentimento da presença de Deus, ou de um toque amoroso dele na alma até a cooperação divina para todos os nossos atos sobrenaturais e para a união acidental, mas imediata entre Deus e nós, entre a sua substância e a nossa, englobando a vida de Deus e suas operações em nós, a nossa vida e as nossas operações nele. Isso é ao mesmo tempo conhecimento e amor. Predominando às vezes o conhecimento, às vezes o amor ${ }^{147}$.

Percebe-se, desta forma, que no místico há uma ativa passividade que se deixa formar por Deus. Ativa por sua decisão, passiva por permitir a entrada de Deus a animá-lo em seu processo de crescimento espiritual. Essa ação constante do espírito santificador conduz à inabitação da Trindade. Nota-se, em suma, três aspectos importantes: que a inabitação contínua no místico é dom e não recompensa; que a espiritualidade, difere-se da mística, por esta última ter mais o acento de uma experiência consciencial da presença de Deus e que ainda pode-se

\footnotetext{
${ }^{144} \mathrm{Idem}$.

${ }^{145}$ BORRIELLO, L. Experiência Mística. In: BORRIELLO, L. et. al. Dicionário de Mística... p. 404.

${ }^{146}$ Idem.

${ }^{147} \mathrm{Idem}$
} 
entender mais especificamente, como o misticismo ${ }^{148}$ torna-se um fenômeno universal, porque ele ultrapassa toda a forma de religião e faz a pessoa unir-se numa ligação imediata com Deus ${ }^{149}$. Percebe-se, igualmente, o quanto o Senhor é Aquele que se deixa encontrar fazendo-se acessível a todos e a cada um.

Para o autor Philip Sheldrake, uma Teologia viva é aquela que está sempre fundamentada na vivência espiritual e se "a quisermos completa precisa ser vivida" $^{" 150}$. O autor acrescenta ao quadro das distinções que aqui se realiza outra importante diferenciação. Desta vez, entre Teologia e Espiritualidade. Para ele a primeira significa a, ou as, tentativas de se falar sobre o entendimento que se tem de Deus, enquanto a segunda, será o movimento de ligar-se à experiência religiosa $^{151}$. Assim, não obstante a conveniência do procedimento didático ou, segundo Sheldrake, não obstante a necessidade da cultura moderna tender à separação destas realidades, não se pode separar a tentativa de se falar de Deus com o desejo de se viver espiritualmente ${ }^{152}$.

Para Sheldrake, é fundamental compreender que a espiritualidade dos sistemas coerentes de crença, ou o compromisso com os grupos religiosos tradicionais. A Igreja e suas doutrinas, por exemplo, têm a função de "metanarrativas". Metanarrativas, segundo o autor, são sistemas completos e exclusivos de pensamento com a função de explicar as estruturas fundamentais da crença (como a doutrina da Trindade, a doutrina da Encarnação), com o objetivo de ajudar as pessoas a dar um sentido à vida e a explicarem-se a si mesmas ${ }^{153}$. Isso não é outra coisa senão a capacidade de se realizar uma leitura, ou de se entender, de forma mais clara, a ação de Deus em seu interior. Ou seja, considerar a relação com o transcendente de forma ainda mais personalizada.

Em síntese, o que desse item se extrai com maior destaque é que, tanto a história cristã do Deus revelado em Jesus Cristo, como a experiência de Teresa de Ávila, ou de tantos outros, na relação intensa que tiveram com Ele, podem ser

\footnotetext{
${ }^{148}$ Misticismo é outro termo com o qual a mística é designada no curso da história ... sinônimo de mística". Idem.

${ }^{149}$ Deste modo todas as pessoas podem ser místicas, independente de serem religiosas, afiliadas a uma instituição, ou inseridas na experiência de situações limites geradas por um contexto propício ao misticismo, isso porque "A experiência mística tem lugar no terreno desse encontro com o Outro, cujo perfil misterioso desenha-se, sobretudo, nas situações-limite da existência e, diante do qual, acontece a experiência do Sagrado". VAZ, H. C. L. Experiência mística... p. 15.

${ }^{150}$ SHELDRAKE, P. Espiritualidade e Teologia... p. 14-17.

${ }^{151}$ Ibidem. p. 49.

${ }^{152}$ Idem.

${ }^{153}$ Idem.
} 
consideradas teologicamente "metanarrativas", dado oferecerem explicações para o significado da existência pessoal na vida de cada um. Além disso, nota-se que o elucidamento dos termos neste espaço foi pedagógico, mas mostra-se aqui, também, a fundamental necessidade da relação dos mesmos, uma vez que teologia, religião, espiritualidade e mística integram-se continuamente.

\subsection{3}

\section{Mística cristã e fenômenos místicos}

Viu-se, anteriormente, as expressões ligadas à mística e o quanto elas se inter-relacionam no favorecimento da relação da pessoa com Deus. Percebeu-se que a mística a espiritualidade e a teologia podem ser observadas de forma mais ampla nas grandes religiões. O presente item dá seguimento ao estudo da mística dissertando sobre a mística cristã e sobre os fenômenos místicos.

Alguns textos acrescentam o adjetivo cristã à experiência mística. Isto, sobretudo, para diferenciá-la da mística não cristã, pois como se sabe, a mística, antes de ser mística cristã é simplesmente: mística. Assim, apriori ao se falar em mística, fala-se daquela que, por ser mais ampla, extrapola fronteiras, incluindo experiências místicas manifestadas fora do cristianismo. E, ao se falar em mística cristã, fala-se na que, segundo a tradição ensinada na Igreja, coloca o foco em Cristo e na revelação.

Assim, se por mística compreende-se a relação do ser humano com seu transcendente e a consciência experiencial dessa relação, por mística cristã compreende-se a relação do ser humano com Deus e essa consciência, mediada por Jesus Cristo e pelos princípios do cristianismo. Contudo, aqui, nos próximos capítulos desta tese, após o aclaramento dos conceitos do capítulo atual, mesmo ao se usar somente a expressão mística, a mística da qual o texto se prolongará refere-se à mística cristã.

Por fenômenos extraordinários místicos entende-se a manifestação visível que eventualmente acompanha a mística. Contudo, antes de analisá-los melhor, é importante perceber dois aspectos: primeiro, o texto que segue limita-se a falar dos fenômenos místicos, ora nas manifestações psicológicas e ora na forma de expressão cristã, que na verdade, não estão necessariamente ligados à santidade da 
pessoa. Discernimento que se fará em seguida. O segundo aspecto importante a se observar é que :

Se a mística constitui um fenômeno humano é porque ainda que a realidade a qual se refira a palavra experiência, no mais íntimo da pessoa de uma realidade sobre-humana, exceda o campo do que se percebe na vida ordinária, se faz presente no mundo humano, através de uma série de manifestações que a convertem em fato histórico, em magnitude humana ${ }^{154}$.

Ao constituir-se fenômeno humano, numa experiência que excede o campo da vida ordinária, dá para se entender porque sua linguagem, a linguagem mística revela-se transgressora. Pois tenta expressar o inexprimível, o que como por assim dizer, extrapola os recursos linguísticos. Assim compreende-se que suas palavras não são domésticas, tampouco domesticáveis e, na maioria das vezes, são quase impossíveis de ser transmitidas ${ }^{155}$. E o linguajar místico "Nunca é um falar ocioso e rotineiro[...], não é simples instrumento comercial, brinquedo estético", mas "anzol destinado a fisgar a alma até Deus" 156 . Por isso, ao se dizer que o místico é poeta, fala-se que ele, ao tentar se exprimir e trazer o céu que assimila à terra, não tem vocabulário suficiente para traduzir o que experiencia. Daí a razão de sua linguagem revestir-se de poesia, encantamento, de suspiros e reticências.

Quanto aos fenômenos extraordinários, adota-se aqui, basicamente, o pensamento de Borriello, com o intuito de diferenciar fenômenos extraordinários dos fenômenos psicológicos. Assim, por fenômenos místicos consideram-se os autênticos, legitimados pela Igreja, ou em processo de legitimação. Por fenômenos psíquicos compreendem-se os ligados à dimensão emocional do humano ${ }^{157}$.

No caso dos fenômenos místicos extraordinários, conforme se adiantou acima, pode-se dizer que, às vezes, nesta relação entre o místico e o Ser Superior podem advir alguns fenômenos visíveis. Esta incidência, num primeiro momento, mostra o quanto a mística é mediada pela corporeidade, assim:

No interior da experiência mística o "corpóreo" pode ser tudo aquilo que o místico traz consigo no encontro com Deus: o seu mundo de sensações e de fé, suas experiências já feitas no relacionamento com os homens e as coisas, seus desejos e esperanças, suas angústias e sofrimentos ${ }^{158}$.

\footnotetext{
${ }^{154}$ VELASCO, M. El fenómeno místico. Madrid: Editorial Trotta S.A, 1999. p. 49. Tradução da autora da tese.

${ }^{155}$ Cf. BALDINI, M. Linguagem Mística. In: BORRIELLO, L. et al. Dicionário de mística... p. 640.

${ }^{156}$ Idem.

${ }^{157}$ Cf. BORRIELLO, L. Experiência mística... p. 400.

${ }^{158}$ SUDBRAK, J. Mística cristã... p. 302.
} 
Quando aparecem as manifestações místicas extraordinárias, considera-se aí a irrupção repentina do Absoluto que se evidencia num caráter geralmente imprevisível e breve, apresentando-se num rompante, rapto, êxtase, ocuções interiores, arroubos, ou na perda de si. Contudo, independente da forma como se apresenta, vale lembrar a respeito das manifestações exteriores e extraordinárias, três aspectos fundamentais: primeiro que a essência da mística não reside, nem tampouco se limita aos fenômenos místicos extraordinários; segundo, que o fundamental para o místico é a união e a comunhão do fiel com Cristo e não suas visões/aparições; terceiro, que a mística acrescida de efeitos extraordinários (a que não procede do modo ordinário de se viver a fé cristã), nunca será considerada um privilégio para ninguém e deve ser criteriosamente avaliada para se autenticar sua legitimidade, ainda que nas maiores e mais evidentes manifestações ${ }^{159}$.

Como dádivas dadas pelo próprio Deus, as graças místicas ordinárias, ou extraordinárias, são consideradas dons em favor de uma comunidade de pessoas. E, tanto no silêncio da comunicação com o transcendente, quanto nas manifestações públicas e manifestas, a mística só terá razão de ser, na ação da graça, na ação do Espírito Santo, que é o que de fato pode favorecer a experiência do encontro entre o humano e o divino, iluminar a inteligência e a vontade e, ainda, mover a pessoa ao amor. Isso justifica a necessidade de sua partilha. Assim,

A experiência mística na tradição cristã[...] é uma experiência que transborda necessariamente dos seus próprios limites e se verte toda na ação, porque o cristão recebe uma graça, um dom e não pode guardá-lo para si. Todo grande místico cristão[...] é um místico que não se detém nas fronteiras de sua experiência, mas quer, como disse Santo Tomás de Aquino, "contemplata aliis tradere": entregar aos outros os bens recebidos na contemplação[...] empenho de toda a sua existência ${ }^{160}$.

Desta forma, a realidade da experiência mística do Deus que transcende o humano, no aqui e no agora da existência, traduz o que Boff expressa: Quem experimenta o mistério de Deus "não pergunta mais, vive simplesmente a transparência de todas as coisas e celebra o advento de Deus em todas as situações"161. Assim, percebe-se que, mesmo vindo acompanhada de fenômenos visíveis, o acento da mística está no presente de Deus para todos, na Sua Auto-

${ }^{159}$ Cf. BORRIELLO, L. Experiência mística... p. 400.

${ }^{160}$ VAZ, H. C. L. Relação entre mística... p. 68.

${ }^{161}$ Cf. BOFF, L. Atualidade da Experiência de Deus. Rio de Janeiro: CRB, 1974. p. 86. 
doação. Por isso, conceitua-se no caráter de cotidianidade e de pessoalidade, porque verdadeiramente a:

A característica de todos os místicos é a qualidade e a intensidade de sua experiência de Deus. A mística cristã não está em ter experiências religiosas extraordinárias, mas pelo contrário, na autenticidade da experiência religiosa ordinária. Neste sentido, todo crente tem algo de místico, embora reservemos a palavra "místico", ou "contemplativo", para aqueles em quem a experiência religiosa, ou a experiência de Deus, é habitualmente muito intensa, autêntica e permanente $^{162}$.

Em síntese, na mística cristã o acento se coloca em Cristo, na revelação e nos princípios do cristianismo. Por fenômenos extraordinários místicos compreende-se, a manifestação visível externa que pode acompanhar a mística. Os fenômenos extraordinários podem ser místicos, ou psicológicos. Os fenômenos místicos são legitimados em sua autenticidade, pela Igreja. Nos místicos que a Igreja coloca como referência para os cristãos, muitas vezes, pode se observar a manifestação repentina do transcendente num rompante, rapto, êxtase, em locuções anteriores, arroubos. Por fenômenos psíquicos consideram-se os comportamentos emocionais e suas manifestações, que podem revestir-se, ou não, de conteúdos religiosos, como por exemplo, comunicações, ou visões do além. As graças místicas, sejam elas ordinárias, ou extraordinárias, são dons em favor de uma comunidade de pessoas e tem razão de ser na ação do Espírito.

\subsection{4}

\section{Fenômenos extraordinários e fenômenos psicológicos ${ }^{163}$}

Tendo-se conceituado no item anterior os fenômenos místicos e os psicológicos extraordinários, passa-se agora a discorrer como se desenvolveram na história. Apura-se, melhor o discernimento dos mesmos e se oferece critérios para se reconhecer a legitimidade do fenômeno extraordinário místico.

Durante muitos séculos na história do cristianismo a manifestação dos fenômenos místicos extraordinários era considerada e, ainda hoje é, inclusive necessária para se legitimar a santidade de alguém, verificar a veracidade de sua palavra e a autenticidade de suas mensagens. Contudo, com a revolução do

${ }^{162}$ GALILEA, S. As raízes da espiritualidade.... p. 28

${ }^{163}$ Todo este item tem como pano de fundo o resumo do verbete "histeria" de FROGGIO G.; PACCIOLA, A. In: BORRIELLO, L. et. al. Dicionário de mística... p. 500. 
Positivismo (séc. XIX), começou a se demonstrar maior rigor científico sobre estes fenômenos e via-se que não apareciam com exclusividade só nos santos, como também não podiam ser considerados somente algo diabólico. Assim, as ciências: medicina, antropologia, psicologia, psiquiatria e outras, animavam-se ao provar cientificamente o quanto os fenômenos místicos extraordinários podiam ser reproduzidos de igual forma por: ingestão de drogas, indução da hipnose, efeito de jejuns prolongados, deficiência de compostos vitamínicos, exacerbação de exercícios físicos, psicopatologias inúmeras, etc.

Desta forma, a mística cristã foi caindo no desencanto. Ao lado disso, por parte da Igreja, era um tempo em que se reinterpretava a Bíblia e a hagiografia dos santos. Com a evolução, a crítica histórica ia ficando mais incisiva em esconder os aspectos miraculosos de alguns fiéis dotados de dons, permitindo aos novos aspectos paranormais suplantarem os prodígios, tornando-os lendas ${ }^{164}$. Assim,

Mística e Modernidade tornaram-se inimigas irreconciliáveis. Apenas os setores mais integristas e não evolucionistas defendiam os milagres e epifenômenos. E quem se considerava progressista e intelectual se via obrigado a relegar este tipo de manifestação ao plano do patológico e do supersticioso. Dessa maneira a mística passou a ser um tema tabu ${ }^{165}$.

Já ao final do século XX, com a crise da modernidade, houve um ressurgimento de tudo o que se relacionava com o Mistério. A partir daí há um deslumbramento crescente pelas diversas correntes milenares, pelos novos produtos religiosos e um evidente e aguçado interesse pelo extraordinário.

Além do ceticismo em relação à fé e ao além, podemos constatar na atual sociedade ocidental, um interesse muito vivo e uma credulidade vaga e generalizada em relação a um tipo de fenômenos misteriosos que parecem evocar referências, ou comunicações com um outro mundo ${ }^{166}$.

A partir de então, as alternativas emergentes tornam-se grandes desafios para o cristianismo, de modo a este ver-se obrigado a resgatar referências importantes de sua tradição mística. Contudo, o diálogo com o novo contexto religioso, somado a toda essa movimentação, não deixa de ser proveitoso. Particularmente, o lado benéfico de tudo isto é que o místico, na atualidade, vê-se

\footnotetext{
${ }^{164}$ Cf. CATALÁN, J. O. Experiência mística e suas expressões. São Paulo: Loyola, 2008. p. 36.

${ }^{165}$ Ibidem. p. 37.

${ }^{166}$ MARTINETTI, G. Razões para crer. São Paulo: Loyola, 1995. p. 360.
} 
chamado, de certa forma, a recuperar sua carta de cidadania ${ }^{167}$. Isso, com maior razão, explica a necessidade fundamental do exercício de discernimento, pois:

Algumas pessoas têm capacidades psíquicas desenvolvidas de maneira quase natural, por herança genética. Existem famílias como a linhagem dos profetas no Antigo Testamento, cujos membros têm uma clara tendência natural para os temas mistéricos, ou dispõem de capacidades perceptivas superiores às dos demais. Depende do treinamento e do contexto religioso no qual se inscreve um indivíduo com essa predisposição genética o fato de que sua experiência se formalize em alguma religião concreta, ou em algum culto de tipo esotérico ${ }^{168}$.

Assim, uns tem dons, outros tendências psíquicas, outros patologias. Outros ainda simulam e é preciso dar-se conta que nem tudo faz parte da mística. Desta forma, aqui, são analisadas duas tipologias: o fenômeno que se considera extraordinário, mas com efeito psicológico e o fenômeno que realmente se enquadra dentro da mística. Quanto aos fenômenos psicológicos é necessário percebê-los a partir de sua origem, saber de onde vem e qual a representação que tem para a pessoa. É necessário lembrar que muitas pessoas experimentam manifestações que julgam místicas, quando apenas estão vivendo uma profunda crise pessoal. As mesmas, ou outras, a partir de questões difíceis de sua existência podem desencadear um modo de viver mais religioso, pois:

Alguns indivíduos quando são duramente golpeados pela vida, submergem num inferno. Para alguns deles, esse inferno particular se torna um lugar de transformação. A morte de algum familiar, um descalabro financeiro, ou uma depressão nervosa podem provocar uma fratura nos estados habituais de sua consciência e, por essa brecha, pode emergir de seu interior uma nova visão da vida. Lembremos que muitos místicos iniciaram seu trajeto interior a partir de uma forte crise derivada de um encarceramento, uma doença, ou algum outro tipo de desgraça ${ }^{169}$.

Nota-se que, pela diversidade das causas que geram, existem muitos enfoques que poderiam ser analisados como efeitos extraordinários. Contudo, quanto à origem das manifestações desses fenômenos psicológicos, (compreendidos algumas vezes como místicos, sem o serem efetivamente), optase, aqui, por circunscrevê-los em meio à análise da patologia de histeria. Isso pelo fato de ter sido este o enquadramento mais repetido, no qual os profissionais da psicologia nascente enquadravam Teresa (tema que se abordará detalhadamente no quarto capítulo). Também, essa opção se dá para se adquirir mais elementos,

${ }^{167}$ Cf. CATALÁN, J. O. Experiência mística... p. 37.

${ }^{168} \mathrm{Idem}$.

${ }^{169}$ CATALÁN, J. O. Experiência mística... p. 39. 
com a finalidade de um posicionamento efetivo neste diálogo entre a mística teresiana e a psicologia. Assim sendo, por histeria compreende-se uma:

Síndrome psicopatológica pertencente ao grupo das neuroses, caracterizada pelo conjunto de sintomas orgânicos e psíquicos. Trata-se da forma psicopatológica conhecida desde as mais remotas épocas. Deve seu nome a Hipócrates (377 a.C.), o qual retomou uma teoria já enunciada por Péricles (429 a.C.), para quem a histeria devia-se a uma doença do útero (hysterus). Acreditava-se, então que era moléstia própria das mulheres e com fundo sexual. Na Idade Média, a histeria costumava ser um dos sinais da possessão diabólica ${ }^{170}$.

As histéricas eram consideradas santas, ou bruxas. Resistiram até o século XVIII. A partir de 1700, começou-se a se descrever os primeiros casos histéricos e, com isso, iniciaram-se as primeiras observações clínicas sobre as possíveis causas orgânicas da histeria. Com os estudos de Charcot, de Janet, de Freud e da psicanálise, a histeria começa a ser definida, cada vez mais, como uma síndrome complexa, de natureza psicológica.

Desde o século XVI, a histeria é descrita como doença mental. E, novamente, sua incidência ocorre principalmente nas mulheres (embora ocasionalmente os homens também fossem descritos como portadores da doença). Sigmund Freud influenciou a atual compreensão psiquiátrica da histeria. Ele escreveu extensivamente sobre especulações relacionadas à causa e tratamento de uma misteriosa perda da função física, envolvendo quase todas as partes do corpo e associada a traumas psicológicos (geralmente envolvendo conflito sexual). Os pacientes histéricos ${ }^{171}$.

No diagnóstico de histeria, três características são importantes ser levadas em conta para se entender melhor a personalidade do paciente histérico e sua relação com o mundo: o modo de se relacionar com a realidade (se o paciente é medroso, tímido, ou excessivamente seguro e forte); o estilo que ele imprime às relações interpessoais (sugestionabilidade e volubilidade, imaturidade) e, ainda, a relação consigo mesmo, caracterizada, sobretudo, por um sentimento de autodesapreço e nota-se que

[...] o paciente histérico apresenta uma peculiaridade: necessita de contato e tem a incapacidade de mantê-lo e aprofundá-lo. Do ponto de vista existencial, tais indivíduos vivem em um contexto de inautenticidade no contato interpessoal; suas relações soam falsas, eles parecem que precisam representar constantemente no seu relacionamento com as pessoas $^{172}$.

${ }^{170}$ FROGGIO G.; PACCIOLA, A. In: BORRIELlO, L. et. al. Dicionário de mística... p. 500.

${ }^{171}$ CAUDILL, M. A. Controle a dor, antes que ela assuma o controle: um programa clinicamente comprovado. Tradução de Denise Maria Bolanho. São Paulo: Summus, 1998. p. 97.

172 DALGALARRONDO, P. Psicopatologia e semiologia dos transtornos mentais. 2. ed. Porto Alegre: Artmed, 2008. p. 323. 
Observa-se que na histeria há dois quadros clínicos principais: a conversão orgânica e a conversão psíquica do conflito psíquico básico. $\mathrm{Na}$ conversão orgânica (física), visualizam-se fenômenos muito semelhantes às verdadeiras doenças neurológicas (ex. a epilepsia). Os sintomas mais comuns são: paralisias persistentes (ainda que irregulares), como astasia, abasia, afasia, contrações musculares; tremores; alterações da sensibilidade com efeitos anestésicos; alterações sensoriais: cegueira parcial, limitação do campo visual, manifestações vicerais, espasmos, alterações tróficas; astenia; distúrbios sexuais.

A característica orgânica que sempre definiu a histeria foi o ataque histérico. Este é semelhante ao grande mal epiléptico, contudo, se particulariza por grande teatralidade. Assoma-se a isso, fenômenos como palpitações cardíacas, dores abdominais, sufocamento e a pessoa vai ao chão em aparente estado de inconsciência. Duram cerca de vinte minutos: enrijecimento do corpo, gritos e movimentos que parecem imitar choques clônicos generalizados. Já na conversão psíquica observam-se com frequência as amnesias parciais, as manifestações excessivas por eventos dolorosos (lutas, perdas, etc) e, em casos mais raros; depressão, tristeza forte, ansiedade, ofuscamento da consciência. Todos estes sintomas pontuados por alguma representação e coexistem a partir de uma fantasia da pessoa histérica de alcançar o desejo do outro. Nestas expressões exacerbadas, a pessoa histérica coloca um significado (fantasioso) de ser para o outro, de certa forma, aquilo que ele deseja e percebe nisso a única forma de poder obter com este outro algum laço social. Assim,

Ataques histero-epiléticos, catalépticos, letárgicos, paralisias, nevralgias, afonias, cegueiras histéricas são todos sintomas que representam o sujeito para o outro (lugar que é sempre ocupado por alguém eleito), o qual está fundamentalmente implicado no desejo da histérica. Esse endereçamento do sujeito ao outro, que não precisa passar pela palavra, é a forma histérica de constituir um laço social ${ }^{173}$.

Os sintomas histéricos do ponto de vista diagnóstico, às vezes não são fáceis de identificar, particularmente porque têm a função de ocultar outras realidades. A personalidade histérica simula inconscientemente a doença, ou usa da própria sintomatologia para esconder a verdadeira natureza dos conflitos, das necessidades e dos incômodos. A dificuldade psicodiagnóstica para se avaliar a

${ }^{173}$ QUINET, A. Um olhar a mais: ver e ser visto na psicanálise. 2. ed. Rio de Janeiro: Jorge Zahar, 2004. p. 195. 
patologia, muitas vezes, encontra-se com maior complexidade nas pessoas com alguma orientação religiosa: liturgias teatrais, ocultamento exibicionista; supostos contatos com o além, sonhos, visões e inspirações, nos quais a própria pessoa visualiza-se no papel de intermediária entre a divindade e seu povo. Essa significação do além, na Idade Média era considerada algo proveniente de uma revelação de Deus, ou da atuação demoníaca ${ }^{174}$. A esse respeito, percebe-se que

As concepções dos antigos sobre a histeria mantiveram-se sob vários aspectos durante alguns períodos da Idade Média (do século V ao XVI). Porém não se pode deixar de considerar as intensas mudanças experimentadas pela civilização nestes vários séculos da nossa história. Entre essas mudanças encontramos as crenças e valores advindos da Igreja sobre as manifestações psíquicas. Assim como as demais afecções, a histeria passou a ter novas explicações, na sua maioria atribuídas a possessões demoníacas. Para a inquisição as histéricas eram bruxas terríveis que se curavam com poções mágicas, copulavam e faziam pactos com o demônio. Como punição eram condenadas à fogueira ${ }^{175}$.

Nota-se que a pessoa histérica tem a necessidade de ser ouvida (como centro das atenções) e não aceita o fato de estar exercendo um papel que dissimule o oposto. No misticismo dos fenômenos psíquicos a simulação (inconsciente), que acompanha a histeria, faz surgir os êxtases, os estigmas, os suores sanguíneos (hematidrose) e outras manifestações psicofisiológicas. Contudo, não obstante ser algo emocional, o sofrimento, nesses fenômenos, tem sempre um papel primário. Daí a importância de prestar-se atenção ao significado que o (místico) histérico dá à dor própria e à alheia para se aproximar à sua origem e ao seu tratamento.

As mais recentes conquistas da Psicologia clínica mostram que muitos dos fenômenos evidenciados na histeria, como "fenômenos místicos", podem ser reproduzidos artificialmente. Contudo, não seria justo e, poderia ser precipitado, julgar que os místicos sejam facilmente hipnotizáveis.

Quanto às graças místicas extraordinárias estas:

São mais difíceis de distinguir, porque estão entrelaçadas com a nossa psique. Por graças místicas me refiro à infiltração da presença de Deus, quando ela nos arrebata espontaneamente. Os níveis de oração mística foram bem descritos por Teresa de Ávila e João da Cruz. Eles incluem o reconhecimento passivo, a oração da quietude, a oração da união e, por fim, a união transformadora ${ }^{176}$.

${ }^{174}$ Cf. FROGGIO G. Histeria... p. 501.

${ }^{175}$ MACEDO, M. M. K. A caça às bruxas: a Idade Média e a histeria. In: MACEDO, M. M. K (Org.). et. al. Neurose: Leituras psicanalíticas. 2. ed. Porto Alegre: EDIPUCRS, 2005. p. 162

176 KEATING, T. Mente aberta, coração aberto: A dimensão contemplativa do evangelho. São Paulo: Loyola, 2005. p. 20. 
Do ponto de vista de Teresa a obra do Castelo Interior, que se abordará mais detalhadamente no quinto e sexto capítulo falarão de sua compreensão a respeito desses níveis de oração. Do ponto de vista teológico, infere-se que a Igreja tem seus próprios critérios para discernir o espírito de onde procedem as manifestações desses fenômenos extraordinários ${ }^{177}$. Para alguns fenômenos extraordinários como, por exemplo, os que aparecem em grupos carismáticos, o Concílio Vaticano II formulou uma criteriologia significativa:

Estes carismas extraordinários, ou mesmo mais simples, e mais comuns, por serem acima de tudo adequados e úteis às necessidades da Igreja, devem ser recebidos com gratidão e consolo. Entretanto, os dons extraordinários não devem ser solicitados imprudentemente, tampouco se deve com presunção esperar deles os frutos dos trabalhos apostólicos, mas o juízo sobre sua genuinidade e o uso ordenado pertence à Autoridade Eclesiástica, à qual cabe principalmente não extinguir o Espírito e sim, examinar tudo e conservar o que é bom ${ }^{178}$.

Desta forma, percebe-se que, a partir de uma análise criteriosa, pode se entender mais claramente aquilo que procede de Deus e do bem, quais frutos deixa à vida, se acena, ou leva à prática da fraternidade.

Embora seja quase impossível, ou ao menos difícil apreender o dinamismo dessa vida toda interior, a Teologia espiritual tenta fixar algumas certezas como origem, crescimento, os meios de amadurecimentos dessa vida e o seu fim último, recorrendo em primeiro lugar à Escritura, à tradição e a experiência, ratificada pelo Magistério, de místicos reconhecidos ${ }^{179}$.

Dos exemplos acima, em síntese, pode-se dizer que se avalia nos fenômenos extraordinários se a procedência é de Deus e do bem, se os resultados levam para Ele, para a vivência concreta do Evangelho e para a prioridade absoluta do amor. A própria Teresa teve seus critérios sobre o discernimento desses fenômenos. Aqui por ora, é importante saber que tanto a teologia, quanto a psicologia têm critérios específicos para avaliar, como também, ambas as ciências percebem que

\footnotetext{
177 “A regra de ouro do discernimento das boas aparições, segundo Antão é que elas produzem "uma alegria inexprimível, um bom humor, a coragem, a renovação interior, a firmeza dos pensamentos a força e o amor de Deus, as outras ao contrário só trazem o "medo da alma a agitação e a desordem interior, tristeza, ódio contra os ascetas, preguiça[...] maus desejos, pusilanimidade para as virtudes e desregramento dos costumes"( Vida de Santo Antão, 36) TENSEK, T. Z. Discernimento. In: MANCUSO, V.; PACOMIO, L. (Orgs.). Lexicon: Dicionário Teológico Enciclopédico... p. 205. Sobre isso pode ainda se ler: Revista Eclesiástica Brasileira/REB. Critérios para discernimento de visões, aparições. v. 59; ed. 233-234. p. 14 e 46 ; MORAS, A. Os entes sobrenaturais na Idade Média: Imaginário, representações e ordenamento social. São Paulo: Anna Blume, 2001. p. 69.; MARCOZZI, V. Discernimento dos espíritos. In: BORRIELLO, L. et. al. Dicionário de Mística... p. 334-336.

${ }^{178}$ Cf. Ts 5,12 e 19-21. As citações bíblicas referem-se A BÍBLIA DE JERUSALÉM. Tradução da Vulgata de Jerônimo, 347-419 d.C. 7. ed. São Paulo: Paulus, 1995.; LG 12.

${ }^{179}$ BORRIELLO, L. Experiência Mística... p. 403.
} 
ainda há muito a aprofundar nesse campo. A colaboração interdisciplinar ligada à honestidade da inteligência e do coração são pressupostos importantes para uma adequada solução e discriminação de fenômenos como esses.

Com a pesquisa até o momento, percebeu-se a importância de discernir os fenômenos místicos em sua natureza e origem, para discriminá-los dos fenômenos psíquicos. De modo que, conforme apresentados acima, os fenômenos místicos tanto podem ser ordinários, como extraordinários. No caso dos fenômenos místicos extraordinários, estes aparecem em sua forma visível através de êxtases, raptos, levitação, etc. São mais raros, mas algumas vezes podem surpreender a uma comunidade inteira e até mesmo à própria pessoa. Pelo fato de aparecerem, não significa que sua essência reside neles, mas no efetivo encontro da pessoa com Deus. Há parâmetros teológicos e psicológicos para julgar com criteriosidade a legitimidade, ou não, dos fenômenos extraordinários místicos, ou o grau de comprometimento psicológico com a doença, dos fenômenos psicológicos.

\subsection{5}

\section{A mística teresiana}

A vida mística de Teresa passou por muitas provações a ponto de ela dizer no relato da vida que por 18 anos não conseguia rezar e lutava entre duas forças as quais se sentia inclinada: ao mundo e à elevação espiritual ${ }^{180}$. Nota-se que ao expressar-se, desta forma, destaca a influência platônica de seu tempo. Deste modo não consegue perceber, ainda, a oração de forma mais integrado às diferentes dimensões da existência. Seu ingresso na experiência mística extraordinária é relatado por ela, em torno de seus $39 \operatorname{anos}^{181}$ :

Vinha-me de súbito na representação interior de estar ao lado de Cristo[...] tamanho sentimento da presença de Deus que eu de maneira alguma podia duvidar que o Senhor estivesse dentro de mim, ou que eu estivesse toda mergulhada nele. Não se tratava de uma visão, acredito ser o que chamam de Teologia mística: a alma fica suspensa de tal modo que parece estar fora de si, a vontade ama, a memória parece estar quase perdida, o intelecto não discorre, mas ao meu parecer não se perde; entretanto repito, também não age, ficando como que espantada com o muito que alcança[...] Deus lhe dá a entender que ela nada compreende daquilo que Sua Majestade lhe representa ${ }^{182}$.

${ }^{180}$ V 4,9; SANTA TERESA DE JESUS. Relações. In: SANTA TERESA DE JESUS. Obras Completas... (A partir de agora abreviada por R) R 4,1.

${ }^{181} \mathrm{~V} 9$ em diante.

${ }^{182} \mathrm{~V} 10,1$. 
Através da citação percebe-se que, Teresa acolhe a presença de Deus como manifestação do Mistério e fala da gratuidade dessas experiências, que são dadas pelo Senhor, inteiramente de graça e frisa que

Trata-se do desapego verdadeiro e natural, que vem sem esforço nosso, pois é dado por Deus. Sua Majestade mostra as verdades eternas de tal maneira que a impressão que deixam em nós nos permite ver com clareza que por nós mesmos não poderíamos obter isso, do modo como o adquirimos, em tempo tão curto ${ }^{183}$.

Assim, compreende Teresa o movimento gratuito e pleno de amor, da parte de Deus, que permite dá-lo a conhecer no mais íntimo da pessoa. E a ação do Espírito a fará perceber o quanto a doação de Deus suscita a fidelidade humana:

Tão logo abandonei as ocasiões e me dediquei mais à oração, o Senhor começou a dar-me graças, como quem desejasse, ao que parece, que eu as quisesse receber. Sua Majestade passou a me conceder com frequência a oração de quietude e, muitas vezes, de união, que durava um longo tempo ${ }^{184}$.

Desta forma, se há fidelidade por parte do humano, a ação salvífica de Deus se reconhecerá e auxiliará a pessoa a focar com maior objetividade o olhar na direção Daquele que ama e à Quem se orienta. Assim, mais intimamente unida a Ele, poderá fazer muitas coisas, porque entende que não é a oração nas alturas que Cristo deseja, mas que obras quer o Senhor, em prol dos irmãos ${ }^{185}$. Desta forma, semelhante à compreensão do encontro com o mistério, como acenava Boff, Teresa sente a alegria de andar na Presença do Senhor e de poder regozijarse n'Ele, a ponto de em todas as ações da vida e no relacionamento com os demais, sentir-se feliz, pois percebe o Senhor em tudo e em todos e, por isso mesmo, as coisas de Deus, para ela, dão-lhe muito contentamento ${ }^{186}$.

Estas se relacionam ao lócus humano, dando significado às coisas da vida. Assim, é o exercício da mística que a faz compreender melhor as coisas de Deus e qualificar sua vida. É a mística que pode trazer a novidade para sua existência e animá-la, alimentá-la e modificá-la em todo seu ser. Por isso, em sua humanidade, gradativamente, deixará transparecer a humanidade de Jesus, que a fez ver tudo com nova sensibilidade (corpo, as coisas, a água, as flores, as pessoas, a alma, o saber, a alegria, a vida, a luz, a Igreja) ${ }^{187}$. Deste modo, dá a entender a todos a

${ }^{183} \mathrm{~V} 38,4$.

${ }^{184} \mathrm{~V} 23,2$.

$1855 \mathrm{M} 3,11$.

${ }^{186} \mathrm{~V} 7,17$

187 ALVAREZ, T. Estudios Teresianos Biografia e História. vol. I. Burgos: Editorial Monte Carmelo, 2000. (Coleção Biblioteca Mística Carmelitana). pp. 42-43. 
mudança na sua vida e agradece a Deus pelo entendimento, amor e pelas graças recebidas, solicitando fortaleza para prosseguir em seu seguimento:

Fortalecei minha alma, preparando-a primeiro, Bem de todos os bens e Jesus meu, ordenando em seguida os meios para vos servir, pois já não suporto receber tanto e nada pagar. Custe o que custar, Senhor, não permitais que eu chegue diante de Vós com mãos tão vazias, pois a recompensa será dada de acordo com as obras. Aqui está a minha vida, aqui está a minha honra e a minha vontade: tudo vos dei, vossa sou, disponde de mim, de acordo com a vossa vontade $^{188}$.

Compreende-se, assim, que para Teresa de Ávila a mística não pode ser separada da vida, mas é o que a move, através de um corpo que vibra com todo seu ser, que sente com toda a sua alma e que ama com todo o seu entendimento e afetividade o que recebeu pela fé e pela graça de Deus ${ }^{189}$. Desta forma, serve-se de todos os seus sentidos, porque a "fé encarnada ensina-a a colocar o corpo num movimento cujo sentido é o próximo, o outro, o que sofre" ${ }^{\text {190 }}$, e porque o corpo humanizado na relação com Jesus Cristo "de fato necessita ser um corpo diferente, senão a fé não seria vivida por pessoas humanas. Esse corpo humanizado a partir da relação com Cristo é o que ama ativamente" ${ }^{191}$. Assim, o mesmo corpo que acolhe Cristo é o que se dispõe ao seu seguimento. É o que está resoluto a sofrer e a cansar-se[...], animado ao trabalho e à peleja, em favor dos irmãos. Nota-se, também, que junto aos fenômenos místicos extraordinários, Teresa irá colocar

[...] mais o acento nos "frutos" tanto teologais como morais desta oração. Teologais porque a oração de quietude infunde um novo conhecimento de Deus, do homem e de tudo. Começa com Deus um amor muito grande". E incentiva fortemente "o desejo de ir adiante na oração"[...]. Morais, pois em todas as virtudes "fica melhorada". Fica com tão grandes efeitos e fortaleza nas virtudes que não se reconhece depois ${ }^{192}$.

Em suma, através da experiência teresiana, percebe-se que entregar-se à mística é viver a vida com toda sua intensidade e plenitude ${ }^{193}$, é ligar a própria vida à vida de Cristo. Neste sentido a experiência de Teresa pode ser considerada metanarrativa e servirá de modelo para a vida de outros cristãos, pois através de

\footnotetext{
${ }^{188}$ V 21,5.

${ }^{189}$ Primeiro mandamento da lei de Deus: “Amar ao senhor teu Deus com toda a alma, com todo o teu coração, com todo teu entendimento e com todas as tuas forças". Mc 12,30.

${ }^{190}$ PEDROSA-PADUA, L. "Eminentemente humana e toda de Deus": Uma leitura antropológica do "Castelo Interior ou Moradas" de Teresa de Jesus. Dissertação de Mestrado. Pontifícia Universidade Católica do Rio de Janeiro, 1995. p. 172.

191 Idem.

${ }^{192}$ HERRAIZ GARCIA, M. Oração: história de amizade. 2. ed. São Paulo: Loyola, 2002. p. 111

193 Jo 10,10 .
} 
sua trajetória é possível experimentar a vida de Cristo, desde sua fé e desde sua encarnação, como Teresa o fez ${ }^{194}$.

\section{3}

\section{Problematização da relação entre ciência e mística}

Neste ítem vê-se a relação entre a ciência e a mística, ao longo da história, a que ponto está na atualidade e aspectos essenciais de sua problematização.

\subsection{1}

\section{Relação entre ciência e mística ao longo da história}

Até aqui pôde se compreender o que é a mística, verificar expressões a ela relacionadas, diferenciar efeitos místicos, mística cristã, efeitos extraordinários místicos e efeitos extraordinários psicológicos. Pôde se aproximar da mística teresiana. A partir desta segunda parte, num olhar retrospectivo da história, podese perceber como a ciência, o autoconhecimento, o conhecimento do outro (psicologia) e a mística nasceram próximos e como na estruturação do método científico, cientistas místicos serviram-se de sua intuição e criatividade, para avançar nas pesquisas científicas em prol de maior conhecimento e humanização.

Já em Sócrates, Platão e Aristóteles, via-se que a ciência e a virtude não vinham somente da razão, mas do conhecimento místico ${ }^{195}$. Para eles, os verdadeiros filósofos são os que amam contemplar a verdade, a alma tem domínio e temperança sobre o corpo e com ela chega-se à ciência do bem, conhecendo-se a si mesmo (Sócrates); Deste modo, "Conhecimento interior é, sobretudo, conhecer o que permanece oculto, ou seja, as coisas divinas e eternas" (Platão) ${ }^{196}$.

Se um Deus nos presenteou com a visão, foi para que contemplando no céu as revoluções da inteligência divina, pudéssemos cogitar dos circuitos que o pensamento percorre em nós[...] graças a um tal estudo, participamos dos cálculos naturais em sua retidão; imitando os movimentos divinos, absolutamente isentos de erros[... $]^{197}$

A teóloga Maria Clara Bingemer traduz o pensamento da investigação histórica e reflexão filosófica de Platão, apresentando na tradição oriental três

${ }^{194}$ Cf. TORRES SANCHEZ,S. Mística y Cristología... p. 76.

195 Sócrates (469-399 a.C.), Platão (428-347 a.C) e Aristóteles (384 a.C.-322 a.C.).

${ }^{196}$ PLATÃO. Apud SILVA JR. N.; FERRAZ, F. Linguagens e pensamento: a lógica na razão e na desrazão. Coleção clínica psicanalítica. São Paulo: Casa do Psicólogo, 2007. p. 23.

${ }^{197}$ Idem. 
grandes formas de mística: especulativa, místérica e profética. Bingemer refere que as duas primeiras, ante ao pensamento filosófico voltado para o mistério do ser, mergulham o olhar nas profundidades inefáveis que assimilam. São comuns ao misticismo grego e cristão e prolongam a experiência metafísica na intensidade da experiência. Já a mística profética, segundo a teóloga, é a mística do pensamento e da palavra: do logos que se define como a mística do conhecimento.

Maria Clara Bingemer refere também que o dualismo do corpo e alma, da matéria e espírito, da inteligência e sensação, presente em Platão e em sua escola, tem caráter espiritual e confirma a doutrina da reminiscência como recurso à dialética, primeira forma de elevação do espírito para além do mundo sensível das aparências ${ }^{198}$. Originalmente foi esse dualismo de corpo e espírito que fez com que a fé mística profética fosse reconhecida como própria do cristianismo. Sendo assim, em sua essência, a mística cristológica é mística profética e "em Platão os estudiosos reconhecem habitualmente a fonte primeira da mística especulativa"199. Entende-se, deste modo, que a mística especulativa tem sua raiz platônica e sob o patrocínio de Platão mística e Filosofia se unem no ocidente por estreitos laços ${ }^{200}$.

Em Aristóteles vê se que o filósofo deixou ampla obra, na qual erige os principais fundamentos da Filosofia que influenciarão o pensamento ocidental em várias áreas: na política, biologia, na física, ética, metafísica, história natural, na psicologia, poesia, lógica, na retórica, zoologia. Para ele o conhecimento humano provém das sensações e ideias e a finalidade da ciência encontra-se em revelar a causa das coisas. Para o filósofo uma leitura da natureza, ou da história, tenta fixar os vestígios de Deus. De modo que para ele, a chegada do conhecimento só pode ser através da mística, pois o misticismo é o único jeito de poder realmente se apreender, por via metarracional, a presença e a natureza de Deus ${ }^{201}$.

Desta forma nota-se que:

Embora ciência e misticismo sejam hoje atividades bem separadas e distintas, nem sempre foi assim. Alguns conceitos e idéias da ciência tiveram sua origem na astrologia, no pensamento metafísico, em concepções esotéricas. Durante o

198 Próprio da Filosofia platônica é a doutrina da reminiscência. Segundo Platão conhecer é "recordar". O encontro com as coisas deste mundo, que são unicamente cópia, faz se recordar das Ideias. Idem.

${ }^{199}$ Idem.

${ }^{200}$ Cf. BINGEMER, M. C. L. As grandes formas da experiência mística na tradição ocidental. In: BINGEMER, M. C. L.; BHARTOLLO JR. R. S. (Orgs.) Mística e Política... p. 22-24.

${ }^{201}$ Cf. CAMBI F. História da Pedagogia. Tradução de Álvaro Lorencini. São Paulo: Fundação Editora da UNESP/FEU, 1999. p. 189. 
Renascimento houve a revitalização de uma concepção mística da natureza, proveniente, em parte, de uma intensa releitura dos textos platônicos, néoplatônicos e herméticos. Esse interesse está presente na obra de muitos pensadores renascentistas, sendo apontado por Debus como um dos elementos que atuaram na gênese da nova ciência que então se desenvolvia ${ }^{202}$.

Depois vieram outros cientistas que tentaram conciliar a mística à ciência. Tycho Brahe $\mathrm{e}^{203}$, por exemplo, homem nobre, que trabalhava como astrólogo e fornecia dados matemáticos a Kepler. Demonstra que a órbita do planeta não era circular, mas elíptica. Chega a demonstrar que a elipse das órbitas planetárias eram uma cônica (remetia à Deus) ${ }^{204}$. Encanta-se com sua fé e tenta conciliar sua mística às conquistas científicas, ao longo de toda a sua existência.

Durante esse tempo pude presenciar um fenômeno que me marcou muito e que o livro do Dreyer a meu respeito conta direitinho: um eclipse parcial do Sol. Ele havia sido previsto com exatidão pelos astrônomos. Eu achei aquilo incrível, que o homem pudesse saber o que aconteceria no reino dos céus. Pareceu-me algo divino que o homem pudesse conhecer o movimento dos astros e predizer suas posições futuras. Eu que sempre fui um cara místico passei a interessar-me pela astrologia ${ }^{205}$.

Depois, Jhoanes Kepler, célebre astrônomo, desejava ser pastor ${ }^{206}$. Era copernicano e ao mesmo tempo fiel à sua fé protestante. Teve uma presença e atuação imperiosa na época da Revolução Científica. Seu misticismo o levou à viagem à Lua, primeira obra de ficção científica, com a qual se renomou autor. $\mathrm{Na}$ apresentação de seu primeiro trabalho em 1597, o Mysterium Cosmographicum, Kepler introduz as próprias concepções a respeito do universo:

Eu não me contentei, entretanto, em reproduzir o esquema de mundo do Copérnico; eu queria mostrar ao mundo que ele fazia um sentido profundo, que havia uma ordem divina subjacente ao mesmo. Foi nesse meu primeiro livro, sob forte influência neo-platônica, que desenvolvi aquela ideia[... ${ }^{207}$.

Em René Descartes, filósofo francês ${ }^{208}$, constata-se, antes de tudo, que ele era tão religioso a ponto de Hermes Benites dizer: "de fato não fazemos nenhuma

\footnotetext{
202 PRAXEDES, G.; PEDUZZI, L. O. Q. Tycho Brahe e Kepler na escola: uma contribuição à inserção de dois artigos em sala de aula. Rev. Bras. Ensino Fís. [online]. 2009, vol.31, n.3, p. 3601.1-3601.10. Epub Sep 25, 2009. ISSN 1806-1117. Disponível em http://dx.doi.org/10.1590/S1806-11172009005000001. Acessado em 05.05.2013, às 9h.

${ }^{203}$ Tycho Brahe (1546-1601).

${ }^{204}$ PRAXEDES, G.; PEDUZZI, L. O. Q. Tycho Brahe e Kepler...

205 Idem.

${ }^{206}$ Jhoanes Kepler (1571-1630). Idem.

${ }^{207}$ Idem.

${ }^{208}$ René Descartes (1596-1650). Idem.
} 
injustiça a Descartes se o vemos como um segundo santo Tomás de Aquino" ${ }^{\text {209 }}$. Descartes fez uma síntese original para integrar revelação cristã e ciência. Para ele o pensamento era atividade própria da alma. "Uma atividade espiritual, em um universo mecânico" 210 . Afirmação que fazia aos céticos que se recusavam a aceitar a existência da alma. Nota-se que foi a partir de Descartes que se começou a separar a ciência da fé. Veja-se sua clara demarcação ${ }^{211}$ :

É verdade que estamos obrigados a cuidar de que nossos raciocínios não nos conduzam a nenhuma conclusão que contradiga o que Deus nos mandou crer, porém creio que tentar derivar da bíblia o conhecimento das verdades que pertencem só às ciências humanas e que não tem conexão com a salvação, é usar das Sagradas Escrituras com um propósito não disposto por Deus e, assim, abusá-las. Porém, possivelmente, o autor não tencionou usar a bíblia desta maneira, nem mesclar coisas sagradas às profanas ${ }^{212}$.

Desta forma, percebe-se que, ao clarificar o que é próprio da ciência e o próprio da fé, Descartes mantém a crença em Deus. Expressa-se com objetividade:

Deve ser fixado firmemente em nossa memória como a regra infalível e suprema que aquelas coisas que nos foram reveladas por Deus devem ser cridas como as mais certas de todas. E que ainda que quiçá alguma faísca de luz da razão possa muito clara e evidentemente sugerir-nos outra coisa, não obstante deve se colocar a confiança somente na divina autoridade, melhor que em nosso próprio juízo. Porém naquelas materiais acerca das quais a fé divina não nos ensina nada, não corresponde em nenhum sentido a um filosofo aceitar como verdadeiro algo que nunca percebeu como verdadeiro ${ }^{213}$.

Deste modo, nota-se que Descartes não está contra a mística, contra a Igreja e a religião, ao contrário. Apenas delimita e discrimina o conteúdo da ciência e da fé, posicionando-se contra o ceticismo. Seu procedimento é com o intuito de discernir, de separar o que antes estava intimamente entrelaçado. Desta forma, por mais que sua obra tenha permanecido mais de quatrocentos anos no Index desde 1663, hoje pode se reconhecer que sua intenção não era afrontar a Igreja, tampouco a de impulsionar o ateísmo, ou o desrespeito aos princípios da fé, mas manter a essência da mística e da ciência. $\mathrm{O}$ que pode ser considerado, do mesmo modo, uma prova contundente de que seu efeito histórico foi arejado,

${ }^{209}$ BENÍTEZ, H. René Descartes: entre la razón y la fe. In: Ensaios de ciência e religião: de Giordano Bruno a Charles Darwin. Santiago: RIL Editores, 2011. p. 151. Tradução da autora da tese.

${ }^{210}$ Idem.

${ }^{211}$ Idem.

${ }^{212}$ DESCARTES. Apud BENÍTEZ, H. René Descartes... p.151.

${ }^{213}$ Ibidem. p. 152. 
empreendedor e salutar para a vida da sociedade e para o desenvolvimento da fé e da ciência ${ }^{214}$.

Em John Locke ${ }^{215}$, filósofo inglês. Na obra Ensaio sobre o entendimento humano desenvolveu sua teoria do conhecimento e manifestou sua rejeição à doutrina das ideias inatas ${ }^{216}$. O pensador crê que todas ideias tem origem no que se percebe, através dos sentidos. Ao definir pessoa, mostra o valor da consciência:

a alma como substancia imaterial e o corpo como substância material são individualidades que unidas dão como resultado o que chamamos de homem. Neste sentido não devemos confundir homem com pessoa, que é o que imputa as ações más e boas, as punições de prêmios e castigos, coisa que não sucede com o homem. Frente às substâncias materiais e imateriais a pessoa se define pelo ter consciência ${ }^{217}$.

Assim, no entender de Locke, todo o conhecimento resulta da percepção, dos hábitos e das experiências pessoais. Através da consciência, a pessoa mostrase um ser inteligente, pensante e na posse de si mesmo. Para ele, a mente humana é lousa em branco (tábula rasa) e a vida política uma invenção humana, que se dá independente das questões divinas. Por isso, luta pela conquista da liberdade religiosa e crê que a revelação pode pontuar o que se descobre na ciência.

John Locke era um cristão com fortes tendências deístas que tentou sintetizar a essência de sua fé em duas verdades básicas: que Jesus era o Messias e que os cristãos deviam viver em harmonia com seus ensinamentos. Suas convicções religiosas foram expressas em dois livros: Ensaio sobre a tolerância religiosa (1667) e a racionalidade do cristianismo (1995). Juntas essas duas publicações revelam a conclusão de Locke de que a liberdade deve estender-se à pratica das crenças religiosas da pessoa e sua convicção de que a revelação enfatiza (e não, contradiz) o que a razão aprende ${ }^{218}$.

Após Locke, a liberdade de expressão religiosa e política começa a ser mais valorizada. Em Isaac Newton ${ }^{219}$, cientista e cristão, religioso e racionalista,

\footnotetext{
${ }^{214}$ Idem.

${ }^{215}$ John Locke (1632-1704). Idem.

${ }^{216}$ Inatismo é uma doutrina filosófica segundo a qual ideias, ou conteúdos mentais estão presentes desde o nascimento, ou seja, não são adquiridos, nem aprendidos. O inatismo se opõe ao empirismo de Locke, que afirma que a mente é uma "tabula rasa" e toda ideia deriva da experiência sensível. As teorias inatistas já estão presentes em Platão e, de semelhante forma, nos modernos, racionalistas dos séculos XVII e XVIII, particularmente Descartes, Espinoza e Leibniz, entre outros. Cf. FERRATER MORA, J. Dicionário de Filosofia. Inatismo. Nova Edição revisada, aumentada e atualizada pelo professor Josep-Maria Terricabras. Supervisão prof. Priscilla Cohn Ferrater Mora. vol. 1. 2. ed. São Paulo: Brasil, 2001.

${ }^{217}$ NODARI, P. C. A emergência do individualismo moderno no pensamento de John Locke. Porto Alegre: EDIPURS, 1999. p. 71-72.

${ }^{218}$ COLLINS, M.; PRICE, M. História do Cristianismo: 2000 anos de fé. São Paulo: Loyola, 1994. p. 157.

${ }^{219}$ Isaac Newton (1643-1727). Idem.
} 
vê-se a passagem da mecânica cartesiana para a mecânica newtoniana. Embora pouco compreendido, apresentava trabalhos alquímicos, como outros cientistas religiosos da história. Matematizou o modelo de Descartes, propondo um formalismo matemático que esclarecia os movimentos planetários, de modo mecânico e sua teoria unificou a mecânica celeste, à mecânica da Terra, colocando fim à compreensão do mundo sublunar e supralunar de Aristóteles. A partir dele, as equações que caracterizavam trajetórias de corpos arremessados na superfície, falavam, da mesma forma, da trajetória da Lua ao redor da Terra e dos planetas ao redor do Sol. Assim: "O que faz uma maçã cair da árvore é a mesma coisa que faz a Terra girar ao redor do Sol”,220.

Por fim, em Darwin ${ }^{221}$, nota-se mais nitidamente a separação entre a mística e a fé. Darwin, embora tivesse influência da religião postulou uma tese que, em seus princípios, pareciam conflitar com o criacionismo. Sua teoria prova que o homem não foi criado do barro, como escrito na bíblia, mas nasceu de uma sucessiva evolução natural ${ }^{222}$. O universo e a evolução fizeram tudo ser o que é ${ }^{223}$.

O jesuíta Pierre Teilhard de Chardin ${ }^{224}$ defendeu uma síntese entre a evolução e a teologia cristã tradicional ${ }^{225}$. Para Urbano Zilles, Pierre Teilhard de Chardin propôs uma visão integradora tentando conciliar a ótica de Darwin que para muitos cristãos de seu tempo, não havia sido vista com bons olhos e escandalizou os princípios da fé. Ao refletir isso, o teólogo tem presente que: "Na Teologia não só o lugar de Cristo é discutido. Também o lugar do homem no universo[...], através da história do pensamento humano" ${ }^{\text {226 }}$. Para ele a posição do homem varia de acordo com o observador. E a "posição do homem e sua função no universo relacionam-se estreitamente com [...] sua dimensão espiritual e material" 227 . Deste modo, a contribuição de Teilhard de Chardin legitima-se em sua visão antropológica da dinâmica do universo em evolução, convergindo para

\footnotetext{
${ }^{220}$ Cf. SANTOS, R. P. Biografia de Isaac Newton. http://www.fisica-interessante.com/biografiaisaac-newton.html, acessado em 19.03.2012, às 9h.

${ }^{221}$ Darwin (1809-1882). Idem.

${ }^{222}$ A exegese bíblica também desmitifica essa afirmação, transferindo-a para um plano simbólico, uma vez que a leitura da Bíblia não deve ser fundamentalista (ao pé da letra), mas precisa ter presente o todo da mensagem de fé.

${ }_{223}$ Cf. BRAKEMEIER, G. Ciência ou religião, quem vai conduzir a história? São Leopoldo: Sinodal, 2006. p. 9-11.

${ }^{224}$ Teilhard de Chardin (1881-1955). Idem.

${ }^{225}$ ZILLES, U. Criação ou evolução? 2. ed. Porto Alegre: EDIPUCRS, 1995. p. 9.

${ }^{226}$ ZILLES, U. Pierre Teilhard de Chardin: ciência e fé. Porto Alegre: EDIPUCRS, 2001. p. 149.

${ }^{227}$ Idem.
} 
Cristo, através do trabalho e dedicação humana. Para ele se a vida e a história estão direcionadas à Cristo, não pode haver incompatibilidade entre ciência e mística, pois o humano colabora com Ele na ação criadora de Deus. No entanto,

[...] a ciência experimental modificou profundamente nossa imagem do mundo. Com ela também o valor moral de muitos de seus elementos. O ideal religioso humano tende a acentuar tendências e a se exprimir em locuções que a primeira vista parecem incompatíveis com o ideal religioso cristão. Aqueles que por formação, ou por instinto, escutam sobretudo a voz da terra receiam, por isso serem infiéis a si mesmos, se permanecerem na linha do evangelho[... $]^{228}$.

Dos tópicos assinalados acima percebe-se, em síntese, que a mística profética foi reconhecida como própria do cristianismo, tornando-se essencialmente, uma mística cristológica. Muitos pensadores, desde o princípio da ciência e ao longo da sua vida tentavam conciliar a ciência com a mística, demonstrando isso através de suas teorias. A partir de Descartes deu-se uma clara demarcação, onde se percebeu mais nitidamente o que é específico da ciência e o que é próprio da fé. Descartes não abdicou da fé, também não se posicionou contra a Igreja, ou a religião. Seu procedimento apenas foi firme e categórico com o objetivo de discernir e separar o que estava intimamente ligado. Ação salutar.

A partir de Darwin e da sua tese do criacionismo, outras interessantes teorias ficaram mais livres de amarras para levantar hipóteses e propor alternativas às questões humanas como a origem e o desenvolvimento da vida. $\mathrm{O}$ secularismo que o antropocentrismo deixou, apesar de desprezado pelo cristianismo por distanciar o humano de sua fé elementar, não deixou de trazer uma bagagem de informação e de desenvolvimento interessante para a sociedade e para a cultura religiosa de diferentes povos. A visão antropológica de Teilhard de Chardin trouxe uma possibilidade concreta de conciliação entre mística e ciência, dado pontuar que a pessoa e o universo, em evolução, convergem para Cristo, através do trabalho e da dedicação humana. Isso faz pensar que, independente da consciência, ou não, que o ser humano tenha de sua origem e do fim da história, celebra em cada um de seus dias e em seus fatos a dinâmica da ação do Espírito, orientando-se à Cristo, Senhor do mundo e Senhor da vida. Nesta ótica pode-se compreender que a vida é dom e graça de Deus, o que não torna incompatível ciência e mística, mas ao contrário, mostra que podem estar unidas, dado o humano colaborar com Ele na ação criadora e continuamente recriadora de Deus.

228 Ibidem. p. 152. 


\subsection{2}

\section{Ciência e mística na atualidade}

Este subtítulo situa a problemática da relação entre a ciência e a mística na atualidade. Mostra como, hoje, há maior busca de superação à ideia de ambas serem adversas. Dá razões para não se afirmar ascendência de uma em detrimento da outra, enfatizando sua complementação para a vida humana e para a sociedade.

Como visto no item anterior muito embora, no princípio, mística e ciência convivessem lado a lado e, na origem, a complementaridade entre uma e outra fosse praticamente incontestável, necessária e natural, nem sempre ao longo da história permaneceu assim. Observa-se, sobretudo, depois de Darwin, a fragmentação das ciências, a distância, o desrespeito e a desvalorização de uma em relação à outra, fechando-se cada qual em sua unicidade.

No que resultou tudo isso? Pôde a ciência sustentar-se em seu poderio absoluto? Pôde a fé sustentar-se sem dados palpáveis para esclarecer às muitas questões que ela mesma formulava? E a que ponto se chegou agora?

Lê-se em um texto do teólogo Urbano Zilles, a respeito da espiritualidade:

Em meados do século XX, muitos temiam que o processo de secularização não só minaria as bases da fé, mas também eliminaria o espaço da religião. Apostava-se na ciência e na técnica como caminho para a solução de todos os problemas humanos. E tudo indica que o subconsciente espiritual se vingou. Nunca houve tamanha proliferação religiosa como na segunda metade do século XX. Tomou-se consciência não só dos limites da ciência e da técnica, mas que a religião brota de fontes profundas do homem. A sociedade ocidental cristã, marcada pela racionalidade científica e despreocupada de promover o cultivo da oração contemplativa, importou gurus da Índia, do Paquistão e de alhures para orientar seus jovens na busca do contato com o Deus transcendente. Milhares de jovens universitários procuram "ashams" hindus para exercitar a meditação transcendental, ou se fecham nos mosteiros zen-budistas para iniciar-se e progredir nas fortes experiências extrassensoriais, ou no relacionamento imediato com Deus ${ }^{229}$.

Da afirmação do teólogo desdobram-se muitas indagações e pode-se, aqui, questionar por que a ciência começa a mostrar-se limitada? Por que nem tudo o que ela mesma, no auge de sua progressão, queria evidenciar, demonstrar e provar foi passível de resultados estritamente quantificáveis? O povo espera pelos resultados da ciência de forma passiva? Vai ele à busca de respostas que saciem sua sede de conhecimento em todos os sentidos? E, quando, neste ínterim, num

${ }^{229}$ ZILLES, U. Espiritualidade cristã... p. 17. 
espaço de maior profundidade da criatura que reivindica aconchego e orientação percebe-se a ciência calar, ou não dar as respostas que se espera em determinado momento, em determinado aspecto, isso desassossega? Quando é mesmo que algo, muito íntimo no ser humano, irá falar mais alto e girar-se em direção a uma maior totalidade? O que será que realmente está por traz deste fenômeno que parece ter feito a Teologia avançar nestes últimos tempos? Será mesmo por ela mostrar-se ao mundo como um portal de esperanças e de caminhos? E estes, tendem a ser, de fato, esclarecedores para as muitas perguntas humanas? Sobretudo quando a vida, em si, se torna uma questão? Será que as questões de espiritualidade e de mística começam a ser consideradas e valorizadas pela necessidade de uma maior ressignificação e de reorientação da existência ao transcendente?

Para Ramon de la Cigoña é impossível a mística e a ciência distanciarem-se a ponto de uma não sentir necessidade da outra. Para ele, ambas realmente são dois caminhos que levam à verdade e à unidade de todo o criado, porque "Ciência e Fé são dois modos complementares de olhar em profundidade o que não se vê a primeira vista" ${ }^{230}$. Segundo esse autor, para um olhar perspicaz há uma imensidão de coisas atrás de cada realidade! Assim mística e ciência não precisam excluirse mutuamente para evidenciarem-se na originalidade e no vigor de suas próprias identidades. Unicamente é preciso estar atento e querer enxergar o que está para além daquilo que se vê. Só assim se poderá fazer uma leitura adequada e compreender que estes dois modos de perceber a vida, em suas especificidades, mostram-se como campos diversos e se inserem em um contexto de mudanças específicas. Basta apenas um pouco de atenção, porque em meio às disputas acirradas entre a ciência e a mística:

[...] a evolução, marca amorosa de Deus, caminha por processos aglutinadores que escapam da vista dos mais distraídos e apressados. Só os cientistas e os místicos, aqueles que têm os instintos apurados, podem perceber o mistério e se aproximar desses umbrais onde o Criador parece caminhar junto das suas criaturas $^{231}$.

Nota-se, neste trecho, que o autor declara como olhar apurado tanto o olhar do místico como o do cientista. Além disso, se, por um lado, ambas as realidades

\footnotetext{
230 LA CIGOÑA, J. R. F. Nos umbrais da mística. Disponível em http://www.clfc.pucrio.br/artigo9.html. Acessado em 19.03.2013, às 19h.

${ }^{231}$ LA CIGOÑNA, J. R. F. Nos umbrais da mística... Acessado em 19.03.2013, às19h.
} 
se distanciaram ao longo da história, por outro, não é de hoje, também, a forte preocupação do diálogo entre fé e ciência. O item anterior, já apontava à aproximação dos muitos cristãos e cientistas a esses umbrais a que se refere Ramon de La Cigoña os quais doaram suas vidas para mostrar ao mundo tal importância. Entretanto, talvez essa questão do diálogo e da aproximação entre a ciência e a mística nunca tivesse feito tanto sentido à sociedade e à vida acadêmica como nestes últimos tempos, onde esta paridade encontra-se reiteradamente em voga, pois estes últimos tempos, como diz Galileia, "trouxeram muitos questionamentos teológicos e pastorais, particularmente, em torno da relação entre a fé cristã e as realidades mundanas" ${ }^{232}$. Então, como é possível perceber a necessidade da mística para a ciência e da ciência para a mística?

Para Ramon de La Cigoña, ciência e fé ao longo da história entraram num jogo de desconfiarem-se mutuamente. Isso descambou no desrespeito, inclusive da própria caminhada e do processo que autoriza ambas em sua especificidade. Contudo, o fato da ciência recorrer à razão como algo elementar, evidenciando sua criticidade, sua objetividade e seu rigor científico, enquanto a mística reiteradamente recorre à fé, isso não altera a qualidade, a validade e o processo da resolução que cada uma apresenta em prol do humano. Porquanto uma aspira o encontro do transcendente e investe na atitude de escuta e de harmonia com toda a criação, enquanto a outra propõe múltiplas aberturas múltiplas para o equacionamento de questões emergidas na vida. Ambas em prol do humano e de um futuro salutar. Além disso, segundo Ramon, hoje a similaridade entre a ciência e a fé, pode ser percebida de forma significativa, pois Ciência e mística fazem parte de uma só realidade. O jesuíta lamenta o fato da academia e da sociedade ainda teimar em polarizá-las e insistir em situá-las somente a partir de um dos $\operatorname{lados}^{233}$. Para ele, isso não integra e não ajuda a entender a necessidade contumaz dessa complementação.

Também Zilles, acredita haver maior sensibilidade no momento atual, no que diz respeito à integração e consideração entre ciência e mística, pois para ele,

A ciência hoje é menos pretensiosa e mais humilde em relação à interpretação global da realidade. [...] a teologia passou a respeitar mais os seus limites, tomou consciência de que a bíblia expressa a revelação de Deus e a fé na visão do mundo da época, numa visão hoje superada. A intenção e o objetivo da

${ }^{232}$ GALILEA, S. As raízes da espiritualidade... p. 5.

${ }^{233}$ LA CIGOÑA, J. R. F. Nos umbrais da mística.... Acessado em 19.03.2013, $19 \mathrm{~h}$. 
bíblia não é ensinar ciência, ou seja a maneira empírica de como se originaram o mundo e o homem. Quer ensinar antes de tudo que Deus é criador do mundo e sua salvação $0^{234}$.

Esta maior clareza, a respeito de cada qual, a que ambos os teólogos se manifestam, é visto por De La Cigoña como algo positivo para ciência e para a mística, sobretudo, porque ao darem-se conta do limite que apresentam em si mesmas, aguçam a necessidade uma da outra. Crê Ramon que, do lado da mística, embora a mesma ofereça intuição e sentido, há um limite. Este se encontra na sua significabilidade, uma vez que o significado do Absoluto fica sempre aquém dos conceitos usados e necessita da ciência para sua própria clarificação. Do lado da ciência, por mais que ela ofereça critérios e competências, não escapará igualmente de seu limite que se encontra na sua provisoriedade, devido às suas certezas estarem sempre abertas às novas hipóteses e às novas possibilidades.

Para De La Cigoña é isso o que define a ciência como ciência e lhe acresce o caráter de transitoriedade, promovendo-lhe a exigência de ser continuamente complementada. Assim, a ciência já não pode se limitar à sedução das experimentações científicas, mas precisa abrir-se à arte de ser feliz, ao descobrir que a sede de conhecimento, não sacia e nem se esgota, uma vez que, para além do enredo, há sempre algo mais profundo. Em momentos específicos, cientistas, inclusive, surpreendem-se diante de mistérios, ao tocá-los muito proximamente, a ponto de perceber que, no fundo da matéria, é possível encontrar procedimentos misteriosos e infinitos, com os quais, poderá ficar surpreso, seduzido e admirado.

Deste modo, o místico que, com simplicidade, alcança a Deus presente em tudo e em todas as coisas, já não será o único privilegiado na percepção do transcendente, do mistério que está além daquilo que se pode ver, uma vez que o cientista, ao fundo de suas pesquisas, também poderá percebê-lo, assim como cada pessoa, em seu cotidiano, ao estar aberta à ação da graça. Isso porque o Deus que se fez humano e está no humano, também está no mistério da vida querendo revelar-se em tudo e para todos, está na verdade daquele que procura a verdade e, que, em outras palavras, $\mathrm{O}$ procura, também. E o faz, porque Ele quer se manifestar aonde quer que a pessoa esteja: na rua, na capela, na criação, na ciência, em tudo, como acenava, anteriormente, a teoria de Boff.

${ }^{234}$ ZILLES, U. Criação ou evolução?... p. 9. 
Assim, no que diz respeito à revelação de Deus, o que de Deus pode-se conhecer manifesta-se aí, na vida, porque Deus lhe manifestou. "Porque as suas coisas invisíveis, desde a criação do mundo, tanto o seu eterno poder, como a sua divindade, se entendem e claramente se vêem nas coisas que estão criadas" ${ }^{\text {235 }}$.

Desta forma, no peregrinar humano, que se faz muitas vezes às apalpadelas e/ou na escuridão, a razão chega como luz e a mística também. E, assim é que ambas, ciência e mística, podem iluminar o caminho humano, pois "não se acende uma lâmpada para colocá-la debaixo de uma caixa, mas no candelabro, onde ela brilha"236 e iluminará a todos. Tendo-se luz para conhecer melhor, também se poderá amar melhor, porque só se ama aquilo que se conhece e quem não ama, não ama, porque não conhece ${ }^{237}$. Desta maneira é que, aqui, pode-se compreender que buscar na ciência e/ou na fé o esclarecimento, a orientação e o conforto é colocar-se a caminho do amor e da humanização, porque:

A divinização do homem comporta a sua plena humanização, numa unificação harmoniosa de todo o seu ser. Em outros termos, participando da comunhão de vida das Pessoas divinas, ele se torna plenamente homem e Deus por participação, no sentido de que atinge amadurecimento humano e espiritual perfeito. Superando seus limites humanos[...] é introduzido nas trevas luminosas do mistério intratrinitário, onde já não distingue mais o conhecer pela fé e o amar por caridade ${ }^{23 \overline{8}}$.

Assim podem se desenvolver os talentos recebidos, por parte do criador, pois buscar a verdade e conhecê-la significa compreender que Deus faz parte deste processo e que, de um jeito, ou de outro, estará junto de seu povo, na busca do esclarecimento para suas questões e na resolução delas. Contudo, sua manifestação e revelação estão sempre além, mas nunca desrespeita os limites da natureza, da compreensão e do existir humano. Por mais que se alcance, nunca se alcançará completamente, porque Deus é sempre maior do que tudo aquilo que se pode sentir, ver, ouvir e entender.

Desta forma, conquanto Deus deixe-se alcançar, sempre haverá na mística a novidade, pois ante o ilimitado de Deus, tudo sempre será pequeno. Deste modo, torna-se legítimo que ciência e mística sigam desafiando-se mutuamente para perceber que por si só não são excludentes. Seus diferentes caminhos, abrem-se às duas vias do conhecimento que sinalizam na encruzilhada de opções dos sujeitos

\footnotetext{
${ }^{235}$ Cf. Rm 1,20.

${ }^{236}$ Mt 5,13-16.

${ }^{237} 1$ Jo 4,8; Santo Agostinho.

${ }^{238}$ BORRIELLO, L. Experiência mística... p. 404.
} 
da história, a direção à uma Verdade, ainda maior: a verdade da origem de tudo, a verdade que é o próprio Deus, ou à verdade de si mesmo, porque como já dizia a Encíclica Fides et Ratio:

A Fé e a Razão (fides et ratio) constituem como que duas asas pelas quais o espírito humano se eleva para a contemplação da verdade. Foi Deus quem colocou no coração do homem o desejo de conhecer a verdade e, em última análise, de $\mathrm{O}$ conhecer, a Ele, para que, conhecendo-O e amando-O, possa chegar também à verdade plena sobre si próprio ${ }^{239}$.

Desta maneira, esse elevar-se para a contemplação da verdade, esse mais profundo desejo do coração humano de buscar uma verdade última, seja da forma mística, da forma psicológica, ou de outra forma científica, de um modo ou de outro, traduzirá a premência da complementaridade entre a ciência e a fé.

Em suma, ciência e mística necessitam complementarem-se mutuamente, identificar melhor suas características, suas possibilidades e seus limites. É preciso dar-se conta de que a experiência religiosa, antes considerada algo alienante e précientífica, pode tornar-se, agora, pós-científica e significativa ${ }^{240}$ dado a cientificidade ser necessária à mística para sua desmistificação e evolução em qualquer processo de discernimento no campo da fé e a mística servir de apoio e referencial à dinâmica do processo cientifico, sempre em movimento.

Esse reconhecimento mútuo resgata algo importante que ficou no tempo em que ciência e mística encontravam-se mais próximas e representa a possibilidade de um diálogo factível e fundamental, uma vez que no limite da mística e na fronteira da ciência, pode-se encontrar o mistério escondido que tudo habita.

\section{4}

\section{Conclusão}

Nesse capítulo viu-se que a ciência, a Psicologia e a mística originalmente nasceram juntas e colaboram com o desenvolvimento humano e da sociedade, auxiliando nas respostas às questões humanas fundamentais. Palavras como consciência, autoconsciência, sujeito, alma, fenômenos, fenômenos místicos são inerentes à mística, à teologia e à psicologia. Estas, por sua vez têm uma

${ }^{239}$ FIDES ET RATIO. Carta Encíclica do Sumo Pontífice João Paulo II aos Bispos da Igreja Católica sobre as relações entre fé e razão. Preâmbulo da introdução. São Paulo: Edições Paulinas, 1998. p. 7.

${ }^{240}$ Cf. LA CIGOÑA, J. R. F. Nos umbrais da mística... Acessado em 16.07.2013, às $11 \mathrm{~h}$. 
intencionalidade comum de fazer a pessoa conhecer-se, de ampará-la na busca de uma verdade que está para além daquilo que visualiza, e ainda, de dar suporte às pessoas para desenvolverem-se, integrarem a personalidade, a psique e todo o ser. Assim, conhecer-se a si mesmo e buscar a verdade última das coisas significa, tanto para a mística, para a psicologia, como para outras ciências, não um privilégio, mas uma necessidade humana, desde os seus primórdios.

A história lembra que ciência e mística, não se separavam e avançavam entrelaçadas, não discordando no essencial, mas completando-se em suas descobertas, de forma harmônica. A partir de Descartes iniciou-se o processo de separação da mística e da ciência. Daí por diante, ficaram cada vez mais discriminadas e avançavam a um horizonte uma, e outra, em outra direção. Não obstante isso, houve crescimento de ambas. A própria história encarregou-se de ser crivo para discernimentos e depuradora das interpretações exacerbadas, favorecendo a afirmação e a originalidade de cada qual. Desta tendência, resultase, nos tempos atuais, sobretudo na pós-modernidade, ampla sede pelo sagrado e pelo universo científico. Nesse sentido, a contribuição das ciências, a observação, a constatação e o confronto que podem oferecer são favoráveis tanto ao crescimento humano, como teórico.

Deste modo, a complementaridade entre ciência e mística é possível no exercício de um sincero reconhecimento de que a sociedade necessita tanto da luz da ciência, como da luz da mística para dar claridade e amplidão às suas questões.

Nessa reflexão, decisões e posturas das diferentes ciências e da mística podem incentivar, ou não, o empenho em se fazer ouvir. Podem dar-se a compreender, ou não, no âmbito da liberdade de expressão. Como, também, podem acolher, ou não, o posicionamento alheio. É possível abrir-se. Ou não, dependendo do posicionamento. Quem sabe, nesta abertura aspirada, ciência e mística podem dar-se, novamente as mãos e novas descobertas serem ainda mais profundas? Quem sabe a sede de sabedoria e de amor não se revitalize? Há tantas verdades nos dois lados da moeda, tanta riqueza para se deslumbrar, se encantar, saborear e fazer poesia! Para que desperdiçar tanta dádiva? Enfim, a ciência sinalizando caminhos para se visualizar a verdade das questões e a mística orientando às novas formas de expressar a relação com transcendente podem auxiliar essa interação entre mística e ciência e animar a sociedade a promover a dignidade humana, a partir do olhar que está para além daquilo que se vê. 


\section{3}

\section{TERESA, MÍSTICA E PSICOLOGIA}

\section{1}

\section{Introdução}

No primeiro capítulo desta tese, visualizou-se a identidade de Teresa, contextualizada na sua época. No capítulo II pôde-se compreender melhor conceitos de mística e o contínuo entrelaçamento desta com a ciência, ao longo da história. O capítulo III objetiva-se a mostrar, ainda mais concretamente, essa sede da contemporaneidade de ir ao encontro do mistério. Dá a entender o uso de expressões e abordagens psicanalíticas e mostra as premissas da psicologia para um olhar sobre a mística e sobre a mística teresiana, procurando situar o desenvolvimento da mística na modernidade.

Como ponto de partida, formulam-se aqui alguns questionamentos: quais fundamentos são importantes no que diz respeito ao olhar da psicologia, da psicanálise, acerca da mística e da mística teresiana? Como é possível perceber na atualidade a sede pelo sagrado, pelo transcendente, por seus significados nas relações com a sociedade pós-moderna? Como pode-se compreender os conceitos da psicologia, de ilusão, de neurose infantil? E, ainda, como entender a relação com Deus na vida do místico, após a desmistificação do senso religioso por alguns mestres do tempo atual?

\section{2}

\section{Uso de algumas expressões e abordagens psicológicas}

Para melhor entender o suposto olhar da psicologia sobre a mística de Teresa registram-se, aqui, premissas que levam em conta o tema do capítulo e evidenciam perspectivas possíveis entre a psicologia, a religião e a mística, pressupostos básicos para a compreensão do capítulo seguinte. Nessas perspectivas visualizam-se os pontos de aproximação e de distanciamento entre a psicologia e a mística, particularizando-se observações em torno das diferentes linhas: freudiana, junguiana e lacaniana. 
Na linguagem comum, os termos: psicanálise, psicologia e psicoterapia, às vezes, parecem ter uma só e mesma conotação. Vale um esclarecimento prévio para seguir-se o desenvolvimento do texto.

Por psicologia, compreende-se a ciência que estuda o comportamento humano e animal e seus processos emocionais e mentais. Enquanto ciência, a psicologia refere-se ao conjunto de conhecimentos sistematizados, obtidos por observação cuidadosa, mensuração de acontecimentos e experimentação rigorosamente planejada ${ }^{241}$.

Por psicoterapia, compreende-se um trabalho terapêutico de atendimento ao paciente/cliente, ou a um grupo de pessoas: familiar, empresarial, ambulatorial, etc., que se serve dos aportes teóricos dessa ciência, como um todo. É importante lembrar que, hoje, com os avanços da psicologia:

o processo psicoterapêutico já deixou de ser visto como um tratamento de doenças para ser considerado, uma aventura de auto-exploração. O terapeuta não desempenha um processo dominante, mas torna-se um facilitador de um processo em que o paciente é o principal protagonista e tem plena responsabilidade ${ }^{242}$.

E nesta relação de ajuda, (seja ela individual, ou grupal), tanto o paciente quanto o terapeuta deixam de lado, na medida do possível, suas respectivas estruturas conceituais, previsões, pressentimentos e as expectativas em relação ao processo e, nesta direção, ambos se mostram:

abertos e ousados, prontos para seguir o fluxo de experiência, com uma confiança profunda em que o organismo descobrirá seu próprio caminho para curar-se e evoluir. A experiência demonstrou que, se o terapeuta estiver disposto a encorajar e apoiar tal jornada curativa, mesmo sem compreendê-la totalmente e o paciente pronto para aventurar-se em território desconhecido, eles serão recompensados por extraordinárias realizações terapêuticas ${ }^{243}$.

Já por psicanálise, compreende-se uma das especializações da psicologia que, entre tantas, se empenha em procurar alívio ao sofrimento humano. A psicanálise trabalha com o sujeito do inconsciente. Seu fundador é Sigmund Freud (1856-1939). Ele cunhou o termo e iniciou essa experimentação já há mais de um século. Embora tendo passado por transformações significativas em seus

${ }^{241}$ Cf. CHAVES, J. A compreensão da pessoa: Psicologia da Personalidade. São Paulo: Editora Ágora, 1992. p. 12.

${ }^{242}$ CAPRA, F. $O$ ponto de mutação: a ciência a sociedade e a cultura emergente. Tradução Álvaro Cabral. São Paulo: Cultrix, 2006. p. 378.

${ }^{243}$ Idem. 
fundamentos metapsicológicos, teóricos, técnicos e clínicos, até hoje esta técnica se mantém em profunda vitalidade ${ }^{244}$.

Na criação do termo psicanálise o "gênio de Freud" certamente inspirou-se na química, tal como comprova a etimologia da palavra "análise", que deriva dos étimos gregos "ana" (partes) + "lysis" (decomposição, dissolução). Freud definiu o que é psicanálise com os seguintes itens: 1 . Um procedimento para a análise dos processos mentais que, de outra forma, são praticamente inacessíveis. 2. Um método baseado nessa investigação para o tratamento de transtornos neuróticos. 3. Uma série de concepções psicológicas adquiridas por esse meio e que se somam, umas às outras, para formar progressivamente uma nova disciplina científica. 4. Posteriormente, ele sublinhou que seus pilares teóricos e técnicos, imprescindíveis, eram a existência do inconsciente dinâmico, o complexo de Édipo, a repressão, a resistência a transferência e a interpretação ${ }^{245}$.

Assim, a priori, a psicanálise baseia-se nas teorias de Freud, depois nos acréscimos e no aperfeiçoamento de seus seguidores que se mantiveram fiéis, ou foram dissidentes aos seus princípios. Como, por exemplo, a linha freudiana (Freud), Junguiana (Jung), winicottiana (Winicott), kleiniana (Melanie Klein), lacaniana (Lacan), etc.

Há diferenças significativas na teoria e na abordagem de cada uma das técnicas utilizadas. Na psicanálise clássica de Sigmund Freud, por exemplo, o uso da livre associação, da interpretação dos sonhos, dos esquecimentos, a resistência do paciente à análise, a pontuação acerca dos atos falhos e a presença dos chistes são fundamentais para um adequado uso do instrumental de observação e de descrição do inconsciente, criado por ele.

Desta forma,

Freud percebeu a expressão do inconsciente presente nos sonhos, nos chistes, nos atos falhos, na negação, na transferência e na resistência à psicoterapia [...] desenvolveu o método de livre-associação como instrumento para a investigação dos conteúdos inconscientes que é, inteiramente não-racional, não lógico, não objetivo ${ }^{246}$.

\footnotetext{
${ }^{244}$ Através da psicanálise o ser humano "pode se tornar um ser verdadeiramente histórico [... ] criar uma história de nós mesmos como raça e como indivíduos, assim como uma história do mundo em que vivemos [... ]. Isso representa o âmago da psicanálise, do esforço de transformar repetições inconscientes ou automáticas [...] em uma ação consciente e recriadora na qual sabemos quem somos nós e os outros, compreendemos como chegamos a ser dessa maneira e conjeturamos o que poderíamos fazer conosco da forma como somos. Em tal atividade da memória que entrelaça passado, presente e futuro em um contexto de sentido intensificado, cada um de nós está a caminho de ser um self'. RIZZUTO, A. M. O nascimento do Deus vivo: um estudo psicanalítico. Tradução Geraldo Korndörfer. São Leopoldo: Sinodal/EST, 2006. p. 81.

${ }^{245}$ ZIMERMAN, D. E. Psicanálise em perguntas e respostas: verdades, mitos e tabus. Porto Alegre: Artmed, 2007. p. 59.

${ }^{246}$ CAVALCANTI, R. O retorno do sagrado: Reconciliação entre ciência e espiritualidade. São Paulo: Cultrix, 2005. p. 131-132.
} 
Sobre a existência desse inconsciente, sabe-se que, junto à criação da psicanálise, são as duas maiores contribuições de Freud para a psicologia. Na verdade, a rigor, o inconsciente não foi "descoberto" pelo arrojado psicanalista, pois já muito antes dele, filósofos e literatos acenavam para esta subsistência. O fato é que, coube a Freud dar ao inconsciente uma dimensão científica, com estudo sistematizado e com aplicação clínica ${ }^{247}$.

Assim:

durante mais de 40 anos, entre avanços, recuos e transformações, entre seguidores fiéis e outros que dissentiram dele, Freud construiu um enorme edifício da teoria e da técnica da psicanálise. Para podermos aquilatar a importância de sua obra basta dizer que Freud foi escolhido como a personalidade mais importante do mundo científico do milênio que passou. Centenas de obras foram escritas sobre ele no mundo inteiro. Seus livros foram traduzidos em 30 idiomas, tendo sido publicadas, no mínimo, 10 biografias sobre a sua vida e a sua obra. Deixou um legado de mais de 300 títulos, sendo 24 livros, mais de uma centena de artigos e uma correspondência avaliada em 15 mil cartas. As sementes que ele lançou, continuam frutificando na atualidade ${ }^{248}$.

Quanto à propulsão da psicanálise, Freud foi um dos primeiros a trabalhar com a técnica concebida da livre associação, sonhos e outras formas de expressão do inconsciente, onde se valoriza o elemento simbólico dele aflorado, trabalhando-o, elaborando e interpretando-o na análise. Com a abordagem freudiana pode-se perceber que, na conduta do paciente, há em tudo algum significado. E este, pode ser tanto manifesto, quanto oculto. E, muito embora, às vezes, este significado não apareça de forma explícita, isso não significa que não esteja ali. Ele está! Contudo, nem sempre pode emergir sem o acesso especializado e direcionado ao inconsciente. Aí reside o valor da teoria e da técnica freudiana: um instrumental para auxiliar a evidenciar o que está encoberto, o que está subterrâneo na pessoa e seus significados. Assim, a análise psicanalítica mostra o quanto, o que está por detrás do comportamento humano, pode influenciar, ou ser fundamental para o contexto de realidade e vida do paciente.

Quanto à interpretação das manifestações do inconsciente, seja através dos sonhos, ou outras evidências, a psicanálise freudiana difere-se da linha junguiana (procedente dela), por esta última compreender a técnica de um modo mais construtivo do que interpretativo. E, desta forma, é que Carl Gustav Jung (18751961) contrapõe o pensamento de Freud: deixando de lado a concepção do

${ }^{247}$ Cf. ZIMERMAN, D. E. Psicanálise em perguntas e respostas... p. 59.
${ }^{248}$ Idem. 
simbolismo individual e interpretativo para, daí por diante, analisar o simbolismo do inconsciente, através do viés do coletivo ${ }^{249}$. Assim Jung:

surge contrapondo o pensamento freudiano interpretativo. Em Símbolos da Transformação, deixa de lado a concepção do simbolismo individual e analisa o simbolismo coletivo, levando os temas míticos a uma tentativa de interpretação dos significados projetivos ocorrido nos indivíduos, destacando que o equilíbrio psíquico, nas projeções, deve-se ao fato de fazer com que todo indivíduo se encontre com seu Eu obscuro, a sua sombra [...]. A força do inconsciente não se manifesta apenas no material clínico, mas, no mitológico, no religioso, no artístico e em diversas atividades culturais expressadas pelo homem ${ }^{250}$.

Além da leitura do inconsciente diferir-se da linha freudiana, Jung defenderá um sistema de interpretação mais extenso, no qual o mito e o sonho refletem, em linguagem semelhante, acontecimentos que marcam a pessoa e a humanidade em sua existência ${ }^{251}$. Ainda outro aspecto importante na linha junguiana é o processo da individuação e da integração da personalidade, um dos seus temas dominantes. Assim, para Jung individuação significa "tornar-se um ser único, na medida em que por individualidade entende-se a própria singularidade"252. Junto à integração a individuação caminha pari passu com a diferenciação e a unificação no desenvolvimento da personalidade ${ }^{253}$.

O primeiro passo para a integração é [...] a individuação de todos os aspectos da personalidade. O segundo estágio é controlado pelo que Jung denomina função transcendente. Essa função é dotada da capacidade de unir todas as tendências contrárias da personalidade e de trabalhar para que se atinja a meta da totalidade. $\mathrm{O}$ objetivo da função transcendente [...] é a realização, sob todos os seus aspectos, da personalidade originalmente oculta no plasma do germe do embrião; a produção e o desdobramento da potencialidade original. A função transcendente é o instrumento da realização da unidade ou arquétipo do eu ${ }^{254}$.

$\mathrm{Na}$ abordagem analítica lacaniana, a presença dos signos, dos significantes e significados é diferente. O tempo de análise, por exemplo, já não será nem lógico, nem cronológico, mas um tempo psicológico. Sua técnica contempla mais a interrupção do que a interpretação, tornando-se distinta a abordagem lacaniana

\footnotetext{
${ }^{249}$ Cf. FORMIGA, N.S; MELLO, I. Testes psicológicos e técnicas projetivas: uma integração para um desenvolvimento da interação interpretativa indivíduo-psicólogo. Disponível emhttp://www.scielo.br/scielo.php?script=sci_arttext\&pid=S1414-9893200 $0000200004 \operatorname{lng}=$ en \& nrm=iso, acessado em 27 May 2013.

${ }^{250}$ Idem.

${ }^{251}$ Cf. JUNG, C. G. O homem e seus símbolos. Rio de Janeiro: Nova Fronteira, 1964. p. 393.

${ }^{252}$ Cf. JUNG, C. G. Apud SAIANI, C. Jung e a educação: uma análise da relação professor/aluno. São Paulo: Escrituras Editora, 2000. (Série ensaios transversais). p. 74.

${ }^{253}$ Idem.

${ }^{254}$ HALL, C. S.; NORDBY, V. J. Introdução à Psicologia Junguiana. Tradução de Heloysa de Lima Dantas. 8. ed. São Paulo: Cultrix, 2005. p. 73.
} 
da sessão analítica freudiana, por exemplo, na qual o tempo da sessão analítica é exato, pontual e interpretativo.

Para Jacques-Marie Émile Lacan (1901-1981), a psicanálise age diretamente no registro do inconsciente. O Eu situa-se no imaginário e se diferencia do Sujeito inconsciente. De modo que, enquanto o Eu, é uma instância de ilusão, de desconhecimento, de alienação, sede do narcisismo e, convive junto aos registros de amor e de ódio, o Sujeito Inconsciente é a instância simbólica e autônoma em relação ao Eu. Para se acessar esse registro simbólico é a via da linguagem que evidenciará o campo do significante para a pessoa ${ }^{255}$.

Deste modo, para Lacan o que interessa é que o sujeito possa agir em função de seu desejo, que ele deixe de ser pessoa, para ser sujeito. Porque no seu pensar, pessoa significa máscara e o analisando só se encontra, efetivamente, se souber libertar-se das máscaras ${ }^{256}$. O inconsciente é para Lacan o grande Outro, o discurso do Outro e o desejo é o desejo do outro. Deste modo, para o analista em questão, a ação da psicanálise encontra seu vigor na linguagem (fala), onde o inconsciente, através de suas formações: atos falhos, esquecimentos, chistes, e sonhos vai estruturar essa mesma linguagem, que liberta e insere a pessoa no convívio social. Desta forma:

Para a psicanálise, sobretudo a partir da reelaboração que Lacan empreendeu dos textos freudianos, o sujeito só pode ser concebido a partir do campo da linguagem[...], ora uma teoria como essa exige, metodologicamente a referência a uma ordem simbólica, a um sistema de articulação de elementos materiais simbólicos, ou seja a linguagem[...] o inconsciente freudiano exige, portanto, um suporte metodológico que o situe no plano conceitual. Em relação a dois estatutos: ele deve ser material (a psicanálise é um saber materialista) e, ao mesmo tempo simbólico (a psicanálise não é biopsicologia). Ora, o campo de referência que oferece a um só tempo essas duas condições metodológicas é a linguagem ${ }^{257}$.

Deste modo, Lacan infere que a linguagem será a pré-condição do inconsciente e o instrumento da cura, o discurso. Recorre à categoria de significante (imagem acústica), à qual associa-se à um conceito (ideia), como significado na constituição do signo linguístico. E, conforme Lacan, é através do processo de constituição do sujeito que o ser humano, ao chegar ao mundo, insere-se na ordem humana. Esta, não apenas precede a sua chegada, mas já

${ }^{255}$ Cf. ELIA, L. O conceito de sujeito. 3. ed. Rio de Janeiro: Zahar, 2010. p. 36-37.

${ }^{256}$ Cf. GOMES, M. R. Repetição e diferenças nas reflexões sobre comunicação. São Paulo: Anna Blume, 2001. p. 67

${ }^{257}$ ELIA, L. O conceito de sujeito... p. 36-37. 
anteriormente criou condições e possibilidades favoráveis para a sua própria inserção nesta ordem. De modo que,

é por este viés que a teoria psicanalítica do sujeito e de sua constituição se articula interna e necessariamente com as categorias [...] sociológicas de sociedade e família: o ser humano entra em uma ordem, que é social e cuja unidade celular e básica, que se organiza como a porta de entrada nesta ordem, se chama família, pelo menos nas sociedades modernas ${ }^{258}$.

Portanto, é desta maneira que a psicanálise pensa o sujeito, em sua raiz: como um ser social, que se insere primeiramente na família e, a partir dela amplia seus lastros sociais. Deste modo, com sua constituição peculiar associada ao plano social, poderá manter sua concepção de sujeito do inconsciente. Sem a qual não se poderia fazer psicanálise, pois a essência da pessoa "se diluiria em meio à polifonia da orquestra das concepções culturalistas de uma construção social do sujeito" ${ }^{259}$. Assim, é necessário "afirmar a dimensão social como algo essencial à constituição do sujeito do inconsciente", ou, ainda, "não reduzí-la a uma sociologia culturalista do sujeito" 260 .

Em outras palavras, só enquanto sujeito pode constituir-se como um ser que pertence à espécie humana. Desta maneira, há a vicissitude obrigatória e não eventual de entrar em uma ordem social, desde a família (ou de seus substitutos sociais, ou jurídicos: adoção, orfananatos, etc). Sem isso, não se tornará humano, pois a espécie humana, por si só, não basta para humanizar a pessoa, nem tampouco mantê-la viva, porque sem a ordem familiar, ou social, o ser da espécie humana acaba por morrer. A essa condição Lacan acena que Freud havia colocado o nome de "desamparo fundamental" do ser humano, pois a mesma exige a contínua intervenção de um adulto próximo, que perpetre a ação específica necessária à sobrevivência do humano desamparado ${ }^{261}$.

Lacan propõe a categoria de Outro (com "O" maiúsculo), para designar não apenas o adulto próximo de que fala Freud, mas também a ordem que este adulto encarna para o ser recém-aparecido na cena de um mundo já humano, social e cultural, que, para simplificar nossa exposição, acompanharemos a sociedade e o chamaremos de bêbe [...]. O Outro não é apenas, portanto, uma pessoa física, um adulto, por exemplo, que pelas mesmas razões mencionadas antes em relação à nomeação do bebê, chamaremos de mãe, porquanto em nossas sociedades seja esta a categoria que designa a função de cuidar dos bebês

\footnotetext{
${ }^{258}$ Ibidem. p. 38.

${ }^{259}$ Idem.

${ }^{260}$ ELIA, L. O conceito de sujeito... p. 38.

${ }^{261}$ Ibidem. p. 39.
} 
e também toda uma ordem simbólica que a mãe introduz no seu ato de cuidar do bebêê $\hat{e}^{262}$.

Essa ordem para Lacan é uma ordem eivada de valores, princípios, significações, ideologias, uma ordem de significante que a mãe comunica ao filho.

O que a mãe transmite, (para além do que ela pretende deliberadamente transmitir), e não poderia ser simplesmente o conjunto de valores culturais (entendendo-se sob este termo toda a complexidade de elementos significativos ordenados na família e na sociedade à qual pertencem a mãe e o bebêe ${ }^{263}$.

Assim para Lacan, o que chega ao bebê, através do Outro materno, não é um conjunto de significados a ser, por ele, meramente incorporados como estímulo, ou fatores sociais de determinação do sujeito com os quais interage na aprendizagem de sua subjetividade, mas um conjunto de marcas materiais $e$ simbólicas, que são os significantes, introduzidas pelo Outro materno e que suscitarão no corpo do bebê, um ato de resposta, que se chama sujeito. Assim, o "sujeito é, portanto, um ato de resposta, uma resposta dada em ato"264 ${ }^{\text {. Lacan }}$ também considera o ser humano um ser faltante, por isso destacou a falta com um lugar central no que concerne ao objeto da psicanálise.

Isso significa que, além da falta do significante que defina seu ser, o sujeito defronta-se com a falta do objeto que possa resolver seu desejo. Este é o real ao qual o Outro se reduz: o real da falta. Está dessubstanciado o Outro. E o sujeito? Como o sujeito lacaniano não é uma alma, não é um eu, não é uma forma, não é uma parte da natureza humana, mas é um sujeito sem substância e advém da intrusão do significante, Lacan vai tratá-lo como resposta do real ${ }^{265}$.

Este sujeito como resposta do real, por ser um ser falante, faltante $e$ pensante se faz também sujeito na cultura, assim,

Para a psicanálise, portanto, a falta é o que nos faz sujeitos na cultura [...] não da cultura, pois não somos meros efeitos da cultura, já que esta carece, tanto quanto o sujeito de ser compreendida a partir dos fatos de estruturas que the conferem inteligibilidade ${ }^{266}$.

De modo que, para a psicanálise, o sujeito e o saber serão sempre uma elaboração e re-elaboração constante na cultura, onde este sujeito se insere.

Em síntese, os termos psicanálise, psicologia e psicoterapia, embora próximos por sua raiz, diferem-se na semântica. Psicanálise é uma entre tantas

\footnotetext{
262 Ibidem p. 39-40.

${ }^{263}$ Idem.

${ }^{264}$ ELIA, L. O conceito de sujeito... p. 40.

${ }^{265}$ THA, F. Categorias conceituais da subjetividade. São Paulo: Annablume, 2007. p. 69

${ }^{266}$ ELIA, L. O conceito de sujeito... p. 49.
} 
especializações da psicologia. Psicologia, por sua vez, é a ciência que estuda o comportamento humano e animal, junto aos seus processos emocionais e mentais. E psicoterapia é um trabalho terapêutico, individual ou grupal, que serve-se dos aportes da ciência da psicologia para uma relação de ajuda, onde o terapeuta é um facilitador e o paciente o principal protagonista.

A psicanálise tem em Freud seu fundador. Freud foi considerado um gênio, a personalidade mais importante do mundo científico do milênio que passou. Seus seguidores e dissidentes levaram adiante seu legado e contribuíram para o avanço, expansão e aperfeiçoamento das diversas escolas, onde se segue, abundantemente, o estudo psico-analítico: junguiana, lacaniana, winicottiana, kleiniana, etc.

As distinções consideradas significativas para serem pontuadas nas três abordagens psicológicas discorridas no presente item, foram: o inconsciente individual de Freud, o inconsciente coletivo de Jung e a força do campo da linguagem para Lacan.

Freud denominou de desamparo fundamental a condição do humano de ser dependente de um adulto para auxiliá-lo na sobrevivência. Lacan refere que o sujeito é ser da falta e só pode se constituir sendo pertencente à espécie humana, por isso, necessita do Outro materno e dos significantes, particularmente da linguagem para seu desenvolvimento na cultura. Em Jung se vê a riqueza dos símbolos, a individuação e a integração da personalidade humana.

\section{3}

\section{Premissas da psicologia para um olhar sobre a mística}

Tendo-se introduzido aos termos e dado pinceladas em enfoques de relevo para algumas linhas da psicologia, passa-se, agora, a destacar: premissas, o que pensam a respeito da mística, psicólogos e psicanalistas e a ver como estão interrelacionadas as interfaces: mística e psicologia. Acena-se, ainda, a tópicos da vida e da obra do fundador da psicanálise e outros a ele relacionados, preparando, assim, o capítulo posterior: o olhar da psicologia em relação à mística de Teresa.

Sabe-se que o misticismo, desde os tempos mais antigos, teve uma importância benéfica para a evolução da humanidade. Nos primórdios os ancestrais encontravam, sobretudo, na natureza, no tempo, no clima, nos animais, na busca de alimentos, ou em abrigos os vestígios da presença do criador. 
Buscavam nestas forças, quase que instintivamente a fortaleza e os recursos para se ajudarem na busca da sobrevivência e na perpetuação da espécie ${ }^{267}$.

Ao longo dos séculos, à medida que o ser humano progredia em suas capacidades de comunicação, fabricação de instrumentos para caça, pesca e lavoura, começaram as suas primeiras indagações acerca de encontrar explicações para os enigmas e mistérios dos fenômenos da natureza, da vida e da morte. Como lhes faltavam recursos intelectuais, especialmente de conhecimentos (da física, por exemplo), tentavam achar as explicações através de um pensamento primitivo, mágico, o que deu origem à criação de inúmeros $\operatorname{mitos}^{268}$.

Desta forma, a mitologia além de oferecer razões para a fé, aos poucos foi dando espaço à mística, à religião

Creio que cabe afirmar que a mitologia foi a primeira religião primitiva, se levarmos em conta que os primitivos se ligavam para encontrar respostas e soluções, para a guerra e para a paz. O verbo "ligar" [...] está destacado justamente para lembrar que a palavra "religião", etmologicamente procede dos étimos latinos re+ ligare, ou seja, esta foi a mais nobre das funções da religião $0^{269}$.

Com isso, a vida se complexificou e foram surgindo os ídolos religiosos: demiurgos, xamãs, sacerdotes, bruxos e outros poderosos equivalentes. Com o passar do tempo, as religiões ficaram mais elaboradas e melhor identificadas em si mesmo, propiciando a crença num único, ou em vários deuses ${ }^{270}$.

De sorte que se consagrou a crença de que havia uma relação entre o homem e um poder sobre-humano, perante o qual ele se submete, acredita e depende. Assim os seres primitivos foram aprendendo a controlar e a administrar os seus impulsos instintivos, graças aos fundamentos religiosos [...]. Da mesma forma, as distintas religiões foram valorizando as emoções humanas, plantando conceitos e crenças, além de ações que os congregavam $[\ldots]^{271}$.

Deste modo percebe-se que, já nos primórdios, aparecia essa sede da pessoa humana de relacionar-se com seu transcendente e, também, que as religiões exerceram influência positiva para a elevação pessoal e espiritual de seus adeptos. Não obstante a crueldade da natureza humana, ao longo da história, muitas vezes, chegou-se a usar a religião, inclusive, como escudo para as forças agressivas.

Assim é certo que as pulsões amorosas convivem com as agressivas, fato este que justifica a razão pela qual no mundo da cúpula da religiosidade, a história universal, nos são relatadas tantas ações violentas processadas em nome do amor: um exemplo flagrante é o relativo à guerra em que os cruzados, em nome

267 ZIMERMAN, D. E. Os quatro vínculos: amor, ódio, conhecimento e reconhecimento na psicanálise e em nossas vidas. Porto Alegre: Artmed, 2010. p. 43.

${ }^{268}$ ZIMERMAN, D. E. Os quatro vínculos... p. 44.

${ }^{269}$ Idem.

${ }^{270}$ Idem

${ }^{271}$ Idem. 
de uma santa necessidade - amorosa - de implantar no Oriente a pureza da religião católica, recrutaram um número enorme de crentes, fizeram um deslocamento que foi por demais longínquo, demorado, caro e que, pior de tudo, custou à humanidade um aterrador número de mortes ${ }^{272}$.

Entretanto, talvez o aspecto mais marcante nesta mescla de amor e ódio no mundo religioso esteja ainda mais evidente nas religiões fundamentalistas, pois

Neste caso, não existia a menor possibilidade de se estabelecer um diálogo que pudesse aproximar as fanáticas facções contrárias. Disso resulta uma explosão de ódio vingativo por parte de todas as facções em litígio, embora todas jurem, e transmitam às novas gerações, seguir uma doutrinação que faz uma intensa apologia da continuação das ações violentas, numa total crença de que tudo isso é feito em nome da justiça e do amor ${ }^{273}$.

Isso faz perceber que amor e ódio, o modo de se lidar com o humano, ou de direcionar os impulsos na vida são objetos de estudo para as ciências. Ora se a mística é uma forma de significar e orientar a vida, pode tornar-se curiosidade e interessante objeto de investigação para os pensadores que procuram estabelecer conexões entre os elementos psicológicos, religiosos, teológicos e antropológicos.

Deste modo é em William James (1842-1910) que se tem o registro do primeiro psicólogo a demonstrar essa preocupação e estender o olhar para a mística. James era religioso e positivista, contudo procurava defender a religião contra um positivismo exagerado, reafirmando continuamente que ela podia impor-se à ciência, justamente por não poder ser demonstrada, ou negada de modo científico. Para James, a experiência mística era a garantia que a pessoa tinha de poder viver com segurança, por isso promulgava que mais que a tentativa de se entender Deus pela razão, valia experimentá-lo a partir da mística ${ }^{274}$. Embasado neste pensamento na sua obra Variedades da experiência religiosa (1902), irá definir quatro etapas no desenvolvimento místico: a) a inefabilidade, como uma característica fundamental para o misticismo que comporta a dificuldade de traduzir a experiência em palavras, dado a linguagem ser insuficiente para trazer o entendimento; b) a qualidade noética que diz respeito à ampliação da capacidade de cognição, onde quem experimenta o estado místico demonstra ter conhecimento dele (insight, iluminação); c)a passividade: na qual temporariamente ficam suspensas a vontade e o controle e onde o sujeito sente-se

\footnotetext{
${ }^{272}$ ZIMERMAN, D. E. Os quatro vínculos... p. 44.

${ }^{273}$ Ibidem. p. 46.

${ }^{274}$ Cf. ZILLES, U. O racional e o místico em Wittgenstein. 3. ed. Porto Alegre: EDIPUC, 2001. p. 21.
} 
conduzido e orientado por uma força superior e d) a transitoriedade, ou brevidade da experiência: que geralmente são descritos por curta duração ${ }^{275}$. Assim, a contribuição de William James à teologia mostra-se um pilar para o estudo da mística, em seus diferentes níveis. Seu olhar em relação à mística comporta, além do reconhecimento de sua importância, uma significativa estruturação.

Na teoria de Wilfred Bion (1897-1979), a noção de místico situa-se no ponto de junção ao processo psíquico de interpretação analítica e trata de um conjunto do conhecimento, cuja abordagem é inseparável da démarche mística. Duas ideias centrais:

A primeira é que a "observação analítica não pode, certamente, ater-se à percepção daquilo que é, apenas, verbalizado". A segunda, inspirada em Freud [...] onde afirma que "a realidade permanecerá para sempre desconhecida" e que o ser humano não pode ter acesso ao conhecimento do objeto em si; Esta realidade, ou verdade última, é designada por Bion como o "ponto O" do qual nós não podemos conhecer senão suas transformações ou evoluções. Entretanto, Bion pensa que se deve tentar ir além ou aquém da sensorialidade, do representável, do pensável; e que o único meio de realizá-lo é por intermédio da démarche mística ${ }^{276}$.

Para Bion, inclusive de modo similar ao místico, o analista deve manter

"por um esforço do ego", uma "disciplina positiva", "rigorosa", que consiste em se impor renúncias - os célebres três Não[s] de Bion. Renunciando a qualquer memória, desejo e compreensão, o analista tem acesso ao que Bion qualifica como "ato de fé". Nestas circunstâncias, ele entende que o essencial do encontro analítico é o esforço do analista para atingir o ponto $\mathrm{O}$ do paciente, para "ser somente um com O", para "ser O", um "estado de união"277.

Nota-se, então, que em Bion, a mística aparece como uma necessidade essencial do humano e contempla possibilidades de integração, a partir de uma visão holística, sistêmica.

Assim, Bion dedicou uma grande parte de sua obra ao estudo do lado espiritual da psicanálise, postulando as suas ideias de uma visão holística (total, sistêmica) do ser humano, de modo que ele enfatizava o valor de conhecer o plano da mística e do misticismo como o melhor caminho para chegar até uma fusão com Deus e a divindade ${ }^{278}$.

${ }^{275}$ Cf. NUNES JUNIOR, A. B. Exxtase e clausura: Sujeito Místico, psicanálise e estética. São Paulo: Annablume, 2005. p. 85.

${ }^{276}$ BOTELLA, C; BOTELLA, S. Místico, conhecimento e trauma. Rev. bras. psicanál, São Paulo, v.43,n.3, set.2009.Disponível em <http: // pepsic. bvsalud. org/ scielo. php? Script =sci arttext \&pid=S0486-641X2009000300016\&lng=pt\&nrm=iso >. Acessado em 05.06.2012, às $12 \mathrm{~h}$. ${ }^{277} \mathrm{Idem}$.

${ }^{278}$ ZIMERMAN, D. E. Os quatro vínculos... p. 46. 
Se para Bion a mística é o melhor caminho para a integração e união com Deus, para Lacan, na explicitação do gozo feminino, observa que se é possível conceber um Deus que goza, a natureza de seu gozo é também a do Outro gozo, do gozo da mulher e aproxima este gozo ao gozo experimentado pelos místicos ${ }^{279}$.

Alguns sujeitos místicos, convictos da transcendência de suas experiências de união mística com o divino, asseguram ter experimentado esse gozo pleno, no corpo. Fato, aliás, que a estética barroca difundiu amplamente, incitando os fiéis a trilharem pelos mesmos caminhos de seus heróis espirituais! O corpo-gozo é plástico [...]. Ele se abre em sentido literal, carnal, ao convite do Outro divino, o que é mostrado, por exemplo, nos chamados casos de estigmatização, nos quais o sujeito reproduz, no próprio corpo, os ferimentos do corpo de Cristo, decorrentes de sua paixão. O místico conforma-se ao Outro divino ${ }^{280}$.

Deste modo, vê-se no entendimento de Miller que o próprio Lacan,

Sempre teve a ideia que a psicanálise não deveria recuar diante da religião, diante da experiência religiosa, isto é, há lugar para autentificar a experiência religiosa como experiência subjetiva. É o que ele propôs em particular com relação aos místicos, porque aí a experiência aparece como algo privado, próprio do sujeito ${ }^{281}$.

Assim para Lacan, na prática da psicanálise, há lugar para se autenticar a experiência religiosa, uma vez que a psicanálise está apta a ouvir a fala do sujeito que revela sua experiência subjetiva, que também pode ser mística. Não deve ser recusada ou enquadrada, de antemão, antes de ser ouvida e examinada, para ser adequadamente validada em sua verdade. Deste modo, o discurso do místico, como tantos outros discursos ouvidos na clínica, relatam experiências a partir da experiência e do laço social que são produzidas e nos quais se encontram inseridos. Desta forma, torna-se referência importante entre tantos outros laços sociais em que se entrelaçam os pacientes. Nesse entrelaçamento é que, de fato, pode-se entender o sujeito. Além disso, ao referir-se ao conceito de gozo na psicanálise, Lacan encontra nos místicos exemplos concretos daqueles que falam sobre suas paixões. Em suma, o olhar da psicanálise de Lacan para a mística é

\footnotetext{
${ }^{279}$ Para melhor entender o que Lacan expressa por gozo é importante perceber que "O termo gozo surgiu no século XV para designar a ação de fazer uso de um bem, com a finalidade de retirar dele as satisfações que ele supostamente proporcionava. Neste contexto o termo reveste-se de uma dimensão jurídica, ligada à noção de usufruto, que define o direito de gozar de um bem pertencentes a terceiros. Em 1503, o termo foi enriquecido por uma dimensão hedonista, tornandose sinônimo de prazer, alegria, bem estar e volúpia[...]. Lacan estabelece, então, uma distinção essencial entre o prazer e o gozo residindo este na tentativa permanente de ultrapassar os limites do princípio de prazer". ROUDINESCO, E. et. al. Dicionário de psicanálise. Gozo. Tradução Vera Ribeiro, Lucy Magalhaes; supervisão da edição brasileira Marco Antônio Coutinho Jorge. Rio de Janeiro: Zahar, 1998. p. 300.

${ }^{280}$ LACAN apud: NUNES JUNIOR, A. B. Exxtase e clausura... p. 96.

${ }^{281}$ MILLER, J. Um esforço de poesia. Apud NUNES JUNIOR, A. B. Êxtase e clausura... p. 12.
} 
um olhar que entrevê a leitura do laço social, da falta, do significante e da linguagem. E a análise do gozo e do sujeito, consideram a subjetividade humana como um todo ${ }^{282}$.

Já para o psicanalista William Reich (1897-1957), que nos seus últimos anos de vida preocupou-se com abordagens sociais, todos os regimes de exceção (incluindo a Igreja) reprimem sexualmente o povo e a rigidez psíquica dos mesmos faz o indivíduo temer a liberdade ${ }^{283}$. Para ele, quanto mais os indivíduos tornam-se dependentes, tanto mais se identificam com um salvador. Ora, esse processo "aborta a autonomização dos grupos e, incentiva o culto ao indivíduo e à força ditatorial" ${ }^{284}$. Nesta direção é que Reich aproxima o misticismo aos regimes de exceção: "o fascismo e todos os tipos de autoritarismo, assim como o misticismo organizado, estão fundamentados nas aspirações orgásticas não satisfeitas das massas"285. Assim, "o misticismo decorre da interpretação dos eventos sob o prisma dos sentimentos íntimos de cada $\mathrm{um}^{286}$. Desta forma, percebe-se que para Reich o misticismo, sobretudo, organizado, torna-se instrumento nas mãos de interesses políticos e enquadra-se no esquema facilitador da dependência e da opressão, o que é, ao mesmo tempo contrário ao movimento de livre expansão, de humanização e de autonomia, inerente ao ser humano.

No entanto para Leon Bonaventure e John Welch, o olhar da psicanálise é de aproximação à mística. Tomam por base a obra e a vida de Teresa de Ávila para mostrar a legítima conexão entre a psicanálise junguiana e a mística teresiana. Ressaltam a extensa e riquíssima simbologia usada pela monja (sol, castelo, centro, tesouro, água, fogo, árvore,...) e crêem que pela via junguiana é possível uma análise clínica, dentro de uma perspectiva integradora e cristã ${ }^{287}$.

Para Waldecir Anacleto, tanto do ponto de vista da psicanálise, como do ponto de vista da religião, pode-se olhar para a mística e obter, em ambas as realidades, pontos de encontro. Para este autor,

${ }^{282}$ Cf. NUNES JUNIOR, A. B. Extase e clausura... p. 12.

${ }^{283}$ Cf. CAMARA, M. V. Reich: grupos e sociedade. São Paulo: Annablume, 2009. p. 123.

${ }^{284}$ Idem.

285 Idem.

${ }^{286}$ LOWEN, A. Uma vida para o corpo: autobiografia de Alexander Lowen. Tradução de Maria silvia Mourão Netto. São Paulus: Summus, 2007. p. 94.

287 BONAVENTURE, L. Psicologia e vida mística: contribuição para uma psicologia cristã. Petrópolis: Vozes, 1975; WELCH, J. Peregrinos espirituales: Carl Jung y Teresa de Jesús. Traducción: María del Carmen Blanco Moreno y Ramón Alfonso Díez Aragón. Bilbao: Desclée de Bouwer 2001. (Caminos 25). Autores como Joyce Ridick, Amedeo Cencini, da Escola de Rulla que adota aspectos junguianos serão usados no último capítulo. 
a psicanálise vê o ser humano como psicossomático sendo que soma é igual a corpo e psique é igual a alma, ambos os termos vem do grego. Então psicanálise, etmologicamente, seria o estudo, ou a análise da alma. A religião cristã também entende o ser humano nesta mesma ótica, acrescentando-lhe o componente espírito. Enquanto a psicanálise lida com a psique e a soma (mente e corpo), a religião lida com os dois, mais o espírito [...]. A psicanálise encontra neste ser humano as [...] composições internas denominadas de Id, Ego, Superego [...], o que bem pode se assemelhar à tricotomia teológica de corpo, alma e espírito ${ }^{288}$.

Anacleto segue neste posicionamento e propõe uma conciliação entre a psicanálise e a fé. Mostra sua argumentação no sentido de evidenciar que ambas podem se entreajudar e não ser inimigas, uma vez que é possível serem parceiras em dar o melhor de si em prol da humanidade.

Para Antoine Vergote, figura eminente no campo da psicologia da religião, a mística relaciona-se com a psicologia (e/ou psicanálise), no sentido de não ser outra coisa senão a história do desejo que, pelo caminho, se tornou religioso. Uma história (ou trajetória) de amor, de investimento no desejo. Vergote crê, também, que mística e psicologia se relacionam no sentido de, esta última, dentro de seus limites, poder ser útil no uso de seu instrumental e olhar crítico, para auxiliar a mística a discernir as necessidades dos desejos e a manter-se no salutar.

Pode-se dizer com justeza: a mística é uma história do desejo que se tornou religioso, uma história também de amor religioso. A psicologia pode observá-la, mas não tem a competência para exercer um juízo de verdade filosófica sobre essa fé em Deus. A psicologia deve, no entanto, por à luz e analisar as diferenças entre a necessidade e o desejo na religião. No desejo religioso, que acabo de evocar, a psicologia pode também reconhecer uma saúde psicológica e uma notável realização da libido sublimada ${ }^{289}$.

O psicólogo manifesta-se sobre a importância de se entender o conceito de necessidade em relação à religião e de se averiguar fatores psicológicos implicados no processo das pessoas sentirem a fé como uma necessidade. Acredita que "sem religião faltaria ao homem um dado essencial para seu desenvolvimento" 290 e que a atual cultura, tanto através da pintura, como pela

288 ANACLETO, W. A psicanálise e a religião: Inimigas, ou parceiras? São Paulo: Biblioteca digital 24x7, 2009. p. 87.

${ }^{289}$ VERGOTE, A. Necessidade e desejo da religião na ótica da psicologia. In: PAIVA, G. J. (Org.) et. al. Entre necessidade e desejo: diálogo entre psicologia e religião. São Paulo: Loyola, 2001. p. 23.

${ }^{290}$ Para maiores informações a respeito deste tema pode se ler obras do autor: Antoine Vergote. Sacerdote católico, belga, teólogo, filósofo, psicanalista. Numerosas publicações na área de Psicologia e religião. Fundador do centro de Psicologia da Religião da Faculdade de Psicologia e das Ciências da Educação de Louvain-la-Neuve, Bélgica, ativo pesquisador na Universidade e às 
poesia recupera a corrente do romantismo que teve grande interesse na mística. O analista, ainda, procura compreender porque apesar de toda cientificidade, de toda a tecnologia e dos novos tempos, as pessoas, em sua grande maioria, ainda são, de alguma maneira, religiosas. Para ele isso é algo fundamental ${ }^{291}$.

Contudo, ao se retornar ao fundador da psicanálise, pontua-se, quanto ao aspecto da intersecção entre a psicanálise e a mística, que não são as diferenças, nem as semelhanças, nem a oposição dos primeiros, tampouco a parceria que aponta Anacleto, ou a evolução da história do desejo de Vergote, mas, em Freud, o acento se dá na evidência e na leitura dos aspectos doentios da religiosidade. Para essa ótica, a própria existência de Sigmund Freud, além de toda a sua obra, tornam-se não somente instigantes, mas oportunamente significativas para a presente reflexão sobre o olhar da psicologia em relação à mística.

Freud nasceu em uma família judaica e conheceu a sua fé. No avanço de seus estudos, percebe a religião com outro olhar, distinto do olhar de suas origens e do olhar da tradição familiar. Ao firmar-se como cientista, a fé será para ele motivo para realçar em suas obras sua hermenêutica e firmar sua convicção pela via da psicanálise. E tão argumentada foi sua obra que, embalando-se nessa dialética entre fé e psicanálise, autores modernos questionam-se, seriamente como se pode crer depois de Freud ${ }^{292}$ Como se pode crer, depois dessa eminente figura histórica, que não somente se declara e se assume como ateu, mas que, além disso, por diversas vias, dá-se ao trabalho de desmistificar aspectos pueris de uma fé que percebe, na maioria das vezes, apresentar-se débil, com perfil imaturo, infantil e, que com certeza, encontra-se, ainda, no limiar de um todo um processo de amadurecimento que não aconteceu?

Para Freud, a neurose obsessiva presente nas mais diversas manifestações religiosas de uma pessoa denota uma neurose individual, enquanto a religião denota uma neurose obsessiva coletiva e universal ${ }^{293}$. Em 1908, quando publicou A moral sexual cultural e o nervosismo moderno, enfatizou a cultura ocidental como a que se constituiu a partir da repressão das pulsões agressivas e eróticas.

pessoas de seus sucessores nos ramos flamengo e valão do Centro de Psicologia da Religião. Cf. PAIVA, G. J. A religião dos cientistas: uma leitura psicológica. São Paulo: Loyola, 2000. p. 9.

291 Idem.

292 No tocante a essas obras, pode-se consultar a própria bibliografia no final desta tese.

293 Cf. DALGALARRONDO, P. Religião, psicopatologia e saúde mental. Porto Alegre: Artmed, 2008. p. 56. 
(Recorda-se, aqui, que sua teoria da sexualidade caiu como uma bomba, não somente para o âmbito da Religião, mas também para o entendimento da sociedade da época e, inclusive, escandaliza aos médicos de seu meio científico. Isso remete a um contexto de realidade da época, no qual seria impossível imaginar mudanças no campo da sexualidade, como a sedução nas histéricas, a sexualidade infantil, o complexo de édipo, o complexo de castração, etc) ${ }^{294}$.

$\mathrm{Na}$ ocasião, Freud afirmou, com ênfase, que a recusa da satisfação libidinal agressiva é sancionada pela religião. Para ele, esse sancionamento mostra-se como uma forma de lidar com as exigências pulsionais e desviar seus fins (sexuais, ou agressivos), no intuito de possibilitar que as pulsões não percam sua força original. A este movimento o fundador da psicanálise denominou: sublimação. Assim, no entender de Freud, a expressão religiosa, seja ela qual for, tanto pode ser uma solução destinada ao sintoma, quanto orientada à sublimação, um dos mecanismos de defesa mais saudáveis e, socialmente, aprovado ${ }^{295}$. Depois das várias publicações de 1907, Freud escreveu Totem e Tabu (1913-1914) ${ }^{296}$, referindo-se à obra, como a seu livro predileto ${ }^{297}$. Nota-se que,

Para Freud o tabu resulta de uma proibição ancestral, imposta sobre indivíduos e consagrada aos desejos e impulsos fundamentais do ser humano. Permanecerá sempre, na espécie humana, o desejo inconsciente de violar o tabu, assim como uma violência profunda relacionada àquilo que o tabu proíbe ${ }^{298}$.

Assim o totem, o animal totêmico seria na realidade um substituto do pai e esse assassinato seria, então, algo indispensável para o crescimento humano ${ }^{299}$.

A conclusão de Freud no final de seu estudo é de que o totem, o animal totêmico, é na realidade, um substituto do pai. Na horda primeva dos ancestrais da humanidade, os irmãos são submetidos a um pai poderoso e tirânico, possuidor de todas as fêmeas e profundamente temido e odiado. Esse pai é, por fim, assassinado pelos filhos. Esse "assassinato fundante" é celebrado em um grande festim, simbolizado pelo banquete totêmico no qual o totem (Deus-Pai) é

${ }^{294}$ Cf. MEZAN, R. A Sombra de Dom Juan e outros ensaios. 2. ed. São Paulo: Casa do Psicólogo, 2005. p. 33.

${ }^{295}$ Cf. DALGALARRONDO, P. Religião, psicopatologia... p. 56.

${ }^{296}$ Curiosamente, Paulo Dalgalarrondo observa que ele escreve com o objetivo de que as pessoas entendam e observem os atos rituais, as obsessões "e a religião e a neurose obsessiva parecem ter sido (para Freud) suas principais obsessões". Cf. DALGALARRONDO, P. Religião, psicopatologia... p. 56-57.

${ }^{297}$ Idem. p. 56-57.

${ }^{298}$ DALGALARRONDO, P. Religião, psicopatologia... p. 57.

${ }^{299}$ Maiores informaç̃os na obra: FREUD, S. Totem e Tabu. [1913(1912-1913)]. Rio de Janeiro: Imago /Ed. Standard Brasileira das Obras Psicológicas Completas de Sigmund Freud. vol. XIII, 1974. 
devorado e depois pranteado. À realização do desejo homicida segue-se a culpa e o arrependimento, com atos, crenças e rituais reparatórios ${ }^{300}$.

Segundo o autor, para Freud esta trama mítica (ou talvez um fato realmente ocorrido), teria deixado vestígios indeléveis no espírito de toda a humanidade. Desta forma, então, é que Freud observou e analisou não somente a religião, enquanto instituição humana, mas também chegou a adentrar, com seu processo de investigação, no caminho do sentimento religioso que, certamente, o intrigava. No Mal estar na cultura (1930), como reflexão despertada por seu amigo escritor e teatrólogo Romain Rolland, Freud dá-se conta de um certo sentimento fundamental para a religião.

O romancista argumentava que, na base de toda experiência religiosa havia, um "sentimento particular", algo que poderia ser denominado "sensação de eternidade". Seria um sentimento de algo "[...] sem limites, sem barreiras, por assim dizer oceânico". Tal sentimento seria puramente subjetivo, não consistiria em um artigo de fé, ou na promessa de sobrevivência da alma pessoal, (mas) representaria a fonte da energia religiosa das diversas igrejas ${ }^{301}$.

Nessa observação em relação a Romain Rolland, Freud percebe algo original e inquietante, que aparece em sua forma primária como necessidade religiosa em todos as pessoas. Ao mesmo tempo, reconhece aí, sua incapacidade pessoal de viver este sentimento oceânico e, lançando mão de seu ceticismo, analisa e argumenta ${ }^{302}$.

que tal sentimento seria, antes, uma visão intelectual, com algum tom afetivo, mas presente em outros tipos de experiência humana não sendo, possivelmente, original, ou exclusivo da religiosidade. Tal vivência de "eternidade", de "fusão com o todo", "representaria um retorno da experiência primeva do bebê, fundido à sua mãe" ${ }^{303}$.

Assim, nota-se que Freud reconhece a religiosidade como vivência humana importante, mas a considera derivada de outras experiências, não experiência primária. A expressão oceânica seria algo semelhante à sem limites, sem barreiras, à uma sensação de eternidade no dizer de Rolland e produto de conservação do passado. Vê-se, que para Freud o sentimento oceânico remonta às fases mais primitivas da formação do eu e seria fonte de energia ligada à um desejo, uma vez que "um sentimento só pode ser fonte de energia, quando

\footnotetext{
${ }^{300}$ DALGALARRONDO, P. Religião, psicopatologia... p. 58.

${ }^{301}$ FREUD, S. Apud DALGALARRONDO, P. Religião, psicopatologia... p. 55-56.

${ }^{302}$ Cf. ROUDINESCO, E. Ilusão. In: ROUDINESCO, E. et. al. Dicionário de psicanálise ... p. 287.

${ }^{303}$ DALGALARRONDO, P. Religião, psicopatologia... p. 55-56.
} 
expressa uma necessidade intensa" ${ }^{304}$. Entende-se, assim, que para Freud há no humano uma necessidade basilar, ligada ao seu desamparo fundamental e definitivo, presente desde a constituição do psiquismo, que faz surgir o desejo. Esse desejo depende de outros para sua subsistência. E, de igual forma, como o sentimento de angústia, move a pessoa em busca da sua concretização. Isso supõe um deslocamento do poder primitivo, que originariamente associa-se às figuras parentais, ou ao super-eu posterior ao período de latência ${ }^{305}$.

Após Totem e Tabu, Freud escreve, em 1927: O futuro de uma ilusão. Com essa obra explica os aspectos psicológicos da inclinação humana à religiosidade $\mathrm{e}$ demonstra como a religião e a fé podem se tornar uma necessidade para o ser humano que busca, ansiosamente, nas mesmas, amparo e proteção. A esse processo de investimento na crença, denomina ilusão ${ }^{306}$. Para Freud a ilusão, tem suas raízes na neurose infantil ${ }^{307}$, sistema de defesa socialmente construído que permite ao ser humano lidar com sua condição fundamental de desamparo e com os intensos sentimentos ambivalentes que experimenta direcionados à figura paterna, ou à representação de alguém mais forte, que de alguma forma, assemelha-se à figura paterna primeira ${ }^{308}$. Assim para Freud, na infância o casal parental, de modo particular o pai, é aquele que garante um papel protetor e que, ao mesmo tempo, faz-se respeitar pelas proibições e regras que determina.

Semelhante à criança, na teoria desse pensador, o sujeito humano precisa encontrar meios adequados para precaver-se das forças da natureza que a cultura e a sociedade não previnem, nem dominam, inclusive da força da morte. Assim, para humanizar as forças aterrorizantes, a pessoa recorre ao pai, ou à figura de proteção que o representa: deuses ou protetores, uma vez que estes irão

${ }^{304}$ Cf. GOLDIFARB, D. C. Demências: clínica psicanalítica. São Paulo: Casa do psicólogo, 2004. (Coleção clínica psicanalítica, dirigida por Flávio Carvalho Ferraz). p. 35.

${ }^{305}$ Freud distingue duas formas de angústia: angústia automática, na qual há uma "situação traumática", provocada pelo excesso de excitação (tanto seja da ordem interna ou externa) e angústia sinal, como forma de reação do eu ante a ameaça da situação de perigo, isto é de se instaurar uma situação traumática. Cf. GOLDIFARB, D. C. Demências... p. 32.

${ }^{306}$ ROUDINESCO, E. O futuro de uma ilusão. In: ROUDINESCO, E. et. al. Dicionário de psicanálise... p. 288.

${ }^{307}$ No texto intitulado Uma neurose infantil "Freud descreve o caso de um paciente que, entre outros distúrbios sofria de uma neurose, que começou imediatamente antes do seu quarto aniversário, uma histeria de angústia (na forma de uma fobia animal), que se transformou então numa neurose obsessiva de conteúdo religioso e perdurou, com as suas manifestações, até os dez anos". MÜLLER, M. J. Merleau-Ponty: acerca da expressão. Porto Alegre: EDIPUC, 2001. p. 246.

${ }^{308}$ Cf. DALGALARRONDO, P. Religião, psicopatologia... p. 56-57. 
assegurar-lhe uma recompensa pelo que precisa suportar. É, deste modo que para Freud,

o indivíduo compensa as limitações criadas ao princípio de prazer pela vida social com a ilusão de sentir-se querido pelo líder. Essa identificação na religião cumprirá uma dupla função compensadora, parte aqui e parte na promessa da outra vida ${ }^{309}$.

Assim, mostra o desejo semelhante à necessidade da criança de agarrar-se ao pai, ou ao anseio do prolongamento da existência para um futuro imortal, referindo que por ser desejo, é ilusão. O "característico das ilusões é que elas são derivadas de desejos humanos" ${ }^{, 310}$. Sendo um ser da falta, o desejo aparece como o que traz à pessoa a complementação e preenche-lhe o vazio. Neste sentido, ilusão é o que oferta a paz, a segurança e o conforto de que tanto necessita.

Nota-se, sobretudo, que Freud ao referir-se à ilusão, diz que, não necessariamente, por ser ilusão, ela é "falsa". Como no exemplo da menina que deseja casar-se com um príncipe. Enquanto desejo, é uma ilusão. Contudo, isso pode vir a ser, realidade. Ou seja, o casamento com o príncipe é a princípio ilusão, mas por mais ilusório que pareça, pode algum dia vir a tornar-se uma realidade. Agora, enquanto unicamente desejo, unicamente ilusão! Deste modo é que se entende que, para Freud, as doutrinas sejam ilusões, dado comportarem esperanças. Contudo, “é impossível tanto refutá-las, como também prová-las”’311.

Ao futuro de uma ilusão o homem de fé, Oscar Pfister (1873-1956), responde-lhe com outro livro: A ilusão de um futuro, afirmando na essência de sua obra que o próprio pensamento de Freud a respeito da religiosidade, poderia enquadrar-se nesta ilusãa $o^{312}$. Contudo, nota-se, aqui, sua grande contribuição, pois

A sua visão de religião como ilusão infantil, como um sistema de defesa é sempre evocada para alinhar Freud no campo dos autores que vêem na religião uma forma de ilusão a ser superada. Isto tudo é certo, entretanto, talvez não seja justo reduzir Freud, simplesmente como querem alguns, a um inimigo cientificista da religião. De fato ele reformulou intrigantes hipóteses sobre a religião e a cultura, propôs conexões revolucionárias entre a experiência cultural e a experiência subjetiva [...] e incitou toda a intelectualidade do ocidente a pensar porque rejeita tão profundamente o corpo, a sexualidade, em essência a irracionalidade ${ }^{313}$.

\footnotetext{
309 ÁVILA, A. Para conocer la psicologia da religión. São Paulo: Loyola, 2007. p. 37.

${ }^{310}$ FREUD, S. O futuro de uma ilusão. Tradução de José Octávio de Aguiar Abreu. Rio de Janeiro: Imago, 1997 (1927). p. 39.

${ }^{311}$ FREUD, S. O futuro de uma ilusão... p. 39.

${ }^{312}$ Cf. ROUDINESCO, E. O futuro de uma ilusão... p. 288.

${ }^{313}$ DALGALARRONDO, P. Religião, psicopatologia... p. 55.
} 
Dado que para estudiosos do fenômeno religioso algumas vezes essa confrontação tão explícita e enfática de Freud soa como um questionamento considerável e desafiador, muitos se perguntam se a fé realmente pode ou, merece, sobreviver frente à critica freudiana, ou de outros teóricos que a instigam, a ignoram ou, ou ainda a desprezam. Para Paul Ricoeur, por exemplo,

a fé só tem a lucrar com um tal confronto numa época "pós-freudiana", seja internamente como exigência de purificação de suas formas de expressão, seja externamente, enquanto estará fazendo jus às exigências da compreensão que, para o homem contemporâneo, não são mais aquelas da fé do carvoeiro, mas aquelas próprias a seu estado de "segunda inocência" [...] tal fé é aquela que superou a religião como estrutura arcaica da vida, enquanto repousa sobre o medo da punição e sobre o desejo de proteção [...]. Na passagem da religião à fé, o ateísmo encontra sua razão de ser revelando a sua dupla significação: como destruição e como libertação ${ }^{314}$.

Deste modo, compreende-se que o ateísmo de Freud, ou de Nietzche, no qual se "proclama a morte do Deus da metafísica e da teologia", (com sua máxima expressão, nos tempos modernos, na ética formal de Kant $)^{315}$, traduz-se, como expressão de libertação, no sentido de Paul Ricoeur e purifica o que não é inerente à fé. Além disso, a crítica freudiana ofereceu para o tempo hodierno uma hermenêutica essencial. De modo que, aqui é compreendida como crítica desmistificadora. Esta enriquece a trajetória do cristão que autenticamente deseja manter-se na essência da sua mística e crescer no relacionamento com o Mistério.

Nota-se, ainda, que a religião não deixou de ser uma questão fundamental para a vida de Freud. Embora se auto-denominasse ateu, não foi indiferente à religião. Prova disto são suas discussões em torno da temática, além das obras nas quais escreve amplamente sobre a religião e a fé. Suas primeiras pesquisas contemplam o estudo a respeito dos sintomas e dos atos obsessivos das práticas religiosas. Sua função se justifica por ser cientista e, com seu novo método, submeter à análise as evidências na relação entre sintomas e a prática religiosa ${ }^{316}$.

Nesse sentido, frisa-se aqui, que a personalidade mais importante do mundo científico no milênio que passou, deixa grande aporte à vida da fé, à

314 RICOUER, P. Apud GUIMARÃES, A. E. A paternidade no confronto entre psicanálise da religião e fé. Porto Alegre: EDIPUCRS, 1999. p. 108.

${ }^{315}$ GUIMARÃES, A. E. A paternidade... p. 108.

316 Estes sintomas, além de incluírem rituais repetitivos trazem consigo "uma angústia da consciência moral pela omissão, o isolamento em relação a obrar em outras esferas da vida" (proibição de ser perturbado), assim como uma escrupulosidade na execução dos detalhes de suas ações (obsessivas de um lado, religiosas de outro). DALGALARRONDO, P. Religião, psicopatologia... p. 56. 
mística e para a religião. Quem sabe hoje, vivendo-se em outros tempos e tendose baixado mais as defesas de ambos os lados, entre mística e ciência, pode-se com maior abertura acolher a essência da mensagem freudiana e reconhecer a efetiva riqueza dessa contribuição tão importante para a virada histórica e para a vida da mística. Quem sabe já não mais tão temerosamente em sofrer a crítica e o rechaço pode o cristianismo, de peito aberto, deixar a mística ser questionada pela psicologia? E vice-versa. Quem sabe o diálogo acrescente a, ambas as partes, novos argumentos e tentativas de perceber pontos de encontro e suas diferenças?

Para concluir, nada mais significativo que evocar, então, em resumo, o epílogo de Morano em sua obra Crer depois de Freud.

Crer depois de Freud significa antes de tudo crer. Crer com todo o temor de quem se arrisca a dar um passo mais além daquilo que se pode ver. Mas a fé depois de Freud, se é que se pode chamá-la, verdadeiramente fé, sabe manter toda a sua determinação e firmeza, pois sabe sentir a necessidade de não diluir sua identidade, nem os conteúdos da fé para acomodar-se...

Crer depois de Freud significa lembrar que o inconsciente apesar de todo o fascínio que suscitou, não pôde ser elevado aos altares. O Deus Pai de quem nos falou Jesus Cristo continua a ser surpreendente, Ele é forte, é grande, mas em nada assemelha-se a Júpiter. Preferiu mostrar sua força e seu poder na fraqueza e na impotência. Sua força, assim é, tão somente a afirmação de um amor que nunca poderá morrer. Jesus ensinou que este amor ultrapassa o narcisismo e a violência e conduz à algo melhor.

Crer depois de Freud significa crer na grandeza do Pai e reconhecer-se filho, no Filho Jesus, a quem o Pai não isenta da sua responsabilidade e nem mesmo da própria morte. Mas é saber, também, que a vida vence a morte! A fé que se confronta com a psicanálise aprende a viver e a permanecer saudável na modéstia das afirmações provisórias, negando-se a qualquer religiosidade que exale o cheiro de carne estragada e morta, porque Deus é, pela ação do Espírito Santo, um Deus Vivo, que concede o ser, anima-o, e o faz sentir e entender.

Crer depois de Freud é colocar a ética no centro de tudo e reconhecer que essa fé é inseparável dos outros, pois ela convida-os tanto para a celebração, como para a partilha. É a realização de um Projeto de Vida, deixando o coração palpitar no chão da história, porque é uma fé experimentada, de maneira radicalmente nova e, na medida em que é alcançada, no mais profundo de seu ser saber, também é uma fé pensada, re-pensada e dita de uma forma nova ${ }^{317}$.

Em síntese, neste ítem, percebe-se que Freud auxilia a entender como nasce a representação de Deus no imaginário humano e a ideia psicológica de Deus, fundamental para o estudo psicológico da religiosidade humana, popular e

317 DOMINGUEZ MORANO, C. Crer depois de Freud. Epílogo. Tradução de Eduardo Dias Gontijo. São Paulo: Loyola, 2003. p. 333-335. Resumo realizado pela autora da tese. 
mística. Desta forma, em sua lógica a ideia de Deus tem por base os vínculos e relacionamentos que a criança estabeleceu na infância. Assim, Deus, para a psicologia de Freud, é a representação que a criança tem de um ser superior que a ampara e a protege frente às ameaças externas, limites da vida e ao abandono.

A necessidade de crer, até mesmo para Freud, é vista como algo vital e inerente ao humano, embora ele mesmo não se admitisse crer. Freud compreende esta representação inicial de Deus, como ilusão. Contudo, pelo fato de ser ilusão, no dizer do próprio psicanalista, ainda não significa que ela não seja verdadeira.

Para os estudiosos da mística que entendem que a imagem de Deus e o próprio ser de Deus desenvolve-se à medida que a pessoa se desenvolve, é possível compreender que a crítica freudiana é necessária para manter a essência da fé e que ainda que se pareça inverossímil é possível crer depois de Freud.

De modo que, da pesquisa realizada, até então, pode-se dizer num parágrafo, que das premissas para o olhar da psicologia em relação à mística, neste texto, pontuaram-se por três aspectos fundamentais: em primeiro lugar pela possibilidade de aproximação e diálogo entre ambas as inter-faces (psicologia e mística), onde se pincelou matizes de alguns psicólogos e psicanalistas em suas abordagens; segundo, pela possibilidade de uma parceria entre mística e psicologia, no que diz respeito à compreensão e desenvolvimento da religiosidade, sobretudo, por entender a psicologia como portadora de um instrumental, do qual a mística pode vir a servir-se, em prol do discernimento e averiguação dos elementos essenciais e salutares à vida cristã e, terceiro, pela condição da psicologia de dirigir-se à mística e, na constatação de elementos excessivos e patológicos como a ilusão, neurose e obsessão poder tratar, pois a mesma ferramenta utilizada para diagnosticar, também é a ferramenta que se apresenta apta a cuidar: preparar, orientar e analisar clinicamente.

\section{4}

\section{A mística na pós-modernidade}

O estudo da fé não tem, pois, fim. Ela jamais será realidade que se esgotará em expressões concretas, pois será vivida [...] em diferentes épocas, por mentes com cosmovisões diversas.[...] Entre o racionalismo seco e estéril e a pura emoção, o cristão oscilará na busca de uma expressão honesta de sua realidade de homem de fé $\mathrm{e}^{318}$.

${ }^{318}$ LIBANIO, J. B. Eu creio, nós cremos: tratado da fé. 2. ed. São Paulo: Loyola, 2004. p. 467. 
Introduziu-se o primeiro capítulo desta tese, reafirmando a frase de Karl Rahner: "o homem do futuro será um místico, ou não será nada"319. Ora o futuro, ao qual Rahner aponta, já está mais próximo do que se imagina e já se iniciou na sociedade atual. Iniciou-se nesta que nasceu no berço da modernidade, adormeceu em seus braços e, depois, despertou efusivamente, com suas características sui generis, ao raiar do novo dia. Agora, avança com ele, já em sua aurora, construindo e firmando sua personalidade, pois foi batizada, de "pósmodernidade ${ }^{320}$.

Por isso, concomitantemente, ao tentar entender como a mística sobreviverá neste tempo e, mais à frente deste tempo, nesse futuro ao qual Rahner se refere, torna-se importante perceber o tempo em que se vive, essa pós-modernidade, seus traços característicos, compreendendo como aí fé transparece.

Assim, pontua-se aqui, sobretudo, o que se dá na passagem entre modernidade e pós-modernidade e como a mística se apresenta e se conduz daqui por diante. Isso sem esquecer, evidentemente, que até mesmo o próprio conceito de pós-modernidade, ainda está se construindo ${ }^{321}$. Por esta razão, importa antes de tudo, observá-lo como um processo, que inclui elementos políticos, culturais, sociais e econômicos que levam à emergência do que já se conseguiu compreender e denominar de pós-modernidade ${ }^{322}$.

No segundo capítulo, observou-se a sede que este novo tempo tem de olhar para o sagrado, para o transcendente, a busca intensa pelo mistério. Nessa direção, o presente item esboça melhor como isso se dá neste período onde emergem amplamente e, por todos os lados, palavras como: novas expressões da religiosidade, religião, Nova Era, misticismo, esoterismo, ecologia, êxtase, etc. Todos esses fenômenos da pós-modernidade são temas fascinantes de pesquisa não só para a teologia e para a psicologia, mas também para a sociologia, filosofia e para as diversas áreas de conhecimento.

Nessa obra teológica, limita-se a observar três aspectos importantes deste período. O primeiro é a expressão contemporaneidade, da qual se fala muito nesse

\footnotetext{
${ }^{319}$ Cf. RAHNER, K. Elementos de espiritualidade... p. 469.

${ }^{320}$ Trecho de criação da autora da tese. Leia-se adormecer no sentido de ser curtida, ser vingada a partir da essência da modernidade. Novo dia, em sentido de novo tempo. Aurora no sentido de estar em seu início, ainda em sua infância.

${ }^{321}$ SPERANDIO, M. R. G. Para entender pós-modernidade. São Leopoldo: Sinodal, 2007. p. 9.

${ }^{322}$ Idem. p. 9.
} 
tempo e cuja significação comporta o que se vive e a implicação do próprio modo de ver, de ser e de se viver na sociedade atual ${ }^{323}$. O segundo aspecto é a palavra indivíduo, que aparece como expressão elementar deste novo tempo ${ }^{324}$. Depois, abordam-se os fenômenos da Nova Era e do pentecostalismo, como expressões características da sede pela mística, próprias desse tempo.

A pós-modernidade é, muitas vezes, definida por alguns autores como um tempo onde se localizam as fragmentações, as indeterminações, as desconstruções, incertezas e rachas na consolidação de valores, etc. Nelas constatam-se os confrontos, as fissuras, a relativização de paradigmas das verdades, do processo de superação pelo qual o atual tempo está passando. Também nessas é possível entrever os caminhos abertos que despontam nas fragmentações para a reinvenção do destino ${ }^{325}$.

Um dos principais porta-vozes desta época, Iahb Hassan, ao caracterizar a pós-modernidade refere-se a ela como a um tempo que explana uma região de indetermanências ${ }^{326}$. O termo, frisa a importância da consciência de que, embora mudanças significativas ocorram na sociedade e se manifestem de forma ainda não completamente claras, isso não significa que sejam menos verdadeiras do que as verdades vividas em épocas anteriores. Para Hassan, o tempo atual caracterizase por um jeito singular de se expressar e traz em si uma série de manifestações intelectuais que influenciam ideias, interpretações, ações, o saber e a sociedade ${ }^{327}$.

Para analisar-se a expressão contemporaneidade e sua significação para o presente tempo, pode-se começar por entender o que entende William Batista, quando se refere às normas paradigmáticas peculiares da pós-modernidade:

Paradigma da contemporaneidade é não se ter paradigma algum[...] isso denuncia a falência dos modelos, o enfraquecimento das verdades, a perda das referências, o colapso do discurso e racionalizações herdadas de uma racionalidade moderna. Essa avalanche de crises que desabam sobre o nosso

${ }^{323}$ SPERANDIO, M. R. G. Para entender... p. 10.

${ }^{324}$ Cf. GIOVANETTI, J. P. Psicologia e senso religioso: a necessidade e o desejo, modalidade da época. In: PAIVA, G. J. et al. Entre a necessidade e desejo: diálogos da Psicologia com religião. São Paulo: Loyola, 2001. p. 91.

${ }^{325}$ Cf. BATISTA, W. Ética e contemporaneidade: sujeito e destruição do destino. In: KOSOVSKI, E; BARATA, A. et. al. Ética na comunicação. Rio de Janeiro: MAUAD, 1995. p. 40.

${ }^{326}$ No silogismo "indetermanências" tem-se a fusão das palavras: indeterminação e imanência. Primeira e última palavra da cadeia das onze características principais do pós-modernismo. Hassan faz uma correlação entre os impulsos mais intensos da arte, das ciências modernas e da consciência pós-moderna, evidenciando suas ambiguidades e indeterminações. Cf. RABAÇA, S. R. Variantes críticas: a dialética do esclarecimento e o legado da escola de Frankfurt. São Paulo: Anna Blume, 2004. p. 112.

${ }^{327}$ Idem. 
tempo e nos faz tomar consciência da amplidão do vazio do nada[...] Efetivamente as respostas vindas da tradição não respondem, nem correspondem mais. Em vez da segurança das definições, o homem contemporâneo se envolve mais com as perguntas e questionamentos. E se inclina mais para a inquietação e para a suspeita",328

Assim, para William Batista, hoje se vive a crise de totalização e de representações, por isso a contemporaneidade não pode ser cabalmente configurada. Só que esse não poder não significa impossibilidade, mas abertura, embora segundo o autor, seja "uma abertura oca para a potencialidade infinita"329, para aquilo que está em vias de chgar e que, até o presente, não pôde se vislumbrar. Nesse sentido é que este tempo não se deixa identificar bem e, por não deixar se identificar, não dá margem à representação, pois não tem suficiente distanciamento para se poder caracterizá-la ${ }^{330}$.

Com isto, o autor mostra haver indicadores de que a cultura atual vive uma nova aporia. Ou seja, assim como na cidade grega clássica se viveu a aporia entre o "logos" e a "physis", hoje se vive "a aporia entre o social e o sujeito" 331 . Em decorrência disto, na contemporaneidade vive-se o lugar do se pôr-em-questão. Abre-se, desta forma, caminho aos dualismos e polaridades, numa perspectiva de multiplicidade, para um estado-de-aberto às diferenças. Ou seja, trata-se de uma abertura para a esfera do sujeito e para a integração do conflito e (não da sua anulação) da tensão entre os diferentes. Deste modo,

as consciências dos sujeitos se posicionam e se interrogam sem a mediação dos pressupostos e certezas dadas pelas definições universalmente válidas. [...]Vivemos uma tal fragmentação que sequer sabemos identificar e formular uma questão fundamental de nosso tempo. Nosso tempo não se detém mais sobre a meditação de um fundamento, e, por isso, não encontra questão fundamental. Qualquer questão, desde que colocada sob o signo do "modus" contemporâneo, pode ser tornada questão fundamental ${ }^{332}$.

Diante da constatação de não se ir mais, hoje, em busca de uma questão fundamental, para Giovanetti faz sentido questionar-se em relação a um problema crucial deste tempo: se a retomada da busca de Deus decorre da necessidade do ser humano de buscar uma referência para melhor organização da vida, ou se esta

\footnotetext{
${ }^{328}$ BATISTA, W. Ética e contemporaneidade... p. 46.

${ }^{329}$ Idem.

${ }^{330}$ Ibidem. p. 42.

331 Por aporia, na filosofia, compreende-se "uma proposição sem saída lógica, como uma dificuldade lógica insuperável. A aporia poderia, pois ser também denominada e de fato assim o foi de antinomia, ou paradoxo". FERRATER MORA, J. Dicionário de Filosofia. Aporia... p. 167.

${ }^{332}$ BATISTA, W. Ética e contemporaneidade... p. 42.
} 
busca é fruto de um desejo, criado pela sociedade, com o objetivo de alienar ainda mais a pessoa neste tempo pós-moderno. Embora a questão de Giovanetti não contemple a dimensão antropológica da essência da fé, que se deixará para Teresa de Ávila, posteriormente, torna-se questão "fundamental" para essa reflexão ${ }^{333}$.

Neste sentido é que se pode pensar na evidência do fenômeno religioso emergido na pós-modernidade ${ }^{334}$. Quando as ciências abordam-no, costumam usar o método fenomenológico, para conhecer sua realidade e avaliar suas possibilidades $^{335}$. Aqui, apenas procura-se entender melhor esta realidade complexa da pós-modernidade e mostrar que os fenômenos religiosos que aparecem nesse tempo não deixam de ser evidência plausível de que as pessoas, independente das realidades em que se inserem e das questões fundamentais que percorrem, buscam a Deus e ao mistério que está para além de si mesmas ${ }^{336}$.

Desta forma, ao debruçar-se sobre os fenômenos da pós-modernidade convém percebê-los como continuação, como resposta à própria modernidade que não chegou a trazer respostas suficientes às perguntas de seu tempo. Assim,

Para que se compreenda a pós-modernidade e sua proposta, é necessário primeiro conhecer aquilo a que ela responde: à modernidade. É também importante ter em mente que falamos em pós-modernidade não necessariamente tomando "pós" em sentido cronológico, como se a modernidade tivesse surgido e a pós-modernidade a tivesse suplantado e apagado todos os seus traços e vestígios, mas justamente no sentido de resposta a $\operatorname{lgo}^{337}$.

Assim, o sujeito na pós-modernidade sempre de novo se descobre e não se realiza nunca. Pois sua realização se constitui no processo de estar se realizando $^{338}$. Com isso compreende-se que, na contemporaneidade, a história da

${ }^{333}$ Cf. GIOVANETTI, J. P. Psicologia e senso religioso... p. 91.

334 Há, como se viu acima, diversos grupos que se apresentam com fortes expressões características do pós-moderno: feiras exotéricas, Nova Era (New Age), Pentecontalismo, neopentecostalismo, misticismo, religião natural, etc. Para se estudar o fenômeno religioso não se parte do conceito de Deus para pesquisar o que acontece nele. Verifica-se, antes, a forma como ele acontece, a intencionalidade de como a pessoa em questão o vive. Não se tem um juízo de valor a respeito da Nova Era e das novas expressões da religiosidade, mas olha-se o fenômeno, tal como se apresenta, procurando identificar nele as suas características significativas.

335 Por método fenomenológico compreende-se "um dispositivo para remontar do dado até a origem da sua significação na consciência; a intencionalidade é o modo [...] de tratar significativamente o problema da relação essencial entre ser e consciência [...] da relação essencial entre pensar e ser". ALVES, P. M. S. Fenomenologia: a metafísica do método. In: FERRER, D. (Org.). Método e métodos do pensamento filosófico. Coimbra: Imprensa da Universidade de Coimbra, 2007. p. 160.

${ }^{336}$ Leia-se aqui, entre aspas "questões fundamentais", no sentido das questões fundamentais deste tempo, conforme a teoria de Giovanetti, acima exposta.

${ }^{337}$ MORAES, J. M. Uma luz que para uns brilha e para outros ofusca no fim do túnel. Revista Veiga Mais. Edição Otimismo. Ano 3. n. 5, 2004-1, p. 7.

${ }^{338}$ Cf. BATISTA, W. Ética e contemporaneidade... p. 45. 
vida e dos fatos ainda espera ser contada, tornada acontecimento, para receber o sentido e o destino que virá depois das interpretações ${ }^{339}$. Nesta linha de reflexão, o lugar da contemporaneidade também é ruptura. Corte e decisão permanentes. É por isso que o tempo nos angustia tanto. Pois é pelo tempo que chegamos à consciência de seres de projeto que somos. Somos projeto nos dois sentidos de "pro-jedum": a) no sentido daquilo que é incompleto e inacabado, e que é histórico e está se fazendo ainda; b) no sentido daquilo que pela consciência se lança, se projeta; abertura para o futuro, para o outro ${ }^{340}$.

De fato, o tempo angustia o humano pós-moderno o desenraiza e o atrai à uma realidade que ainda não encontrou: nem dentro, nem fora de si, nem antes, nem no momento presente. Faz frente à inevitabilidade das rupturas e subverte $o$ destino que se dá aos passos e esperanças ${ }^{341}$. Por isso, o lugar da contemporaneidade pode ser, também, o lugar do estranhamento do mundo e de si mesmo. Pois cada um é o que é, com o seu tempo e com aquilo que lhe evade ${ }^{342}$.

Aquele que viaja no filme $O$ viajante de Volker Schloendorff, não termina a sua viagem nunca ${ }^{343}$. Viaja à procura dele mesmo e do tempo que lhe escapa. É uma peregrinação sem fim por estradas e portos, hotéis, museus e ruínas. O próprio caminho que percorre vai legitimando a sua obsessão pelo encontro. De tão incomodado, com ele mesmo e com o mundo, viaja e estranha o rosto do homem que ainda não sabia que era seu irmão, amigo e rival de sua juventude. Aquele que no fundo não sabia que queria reencontrar. Mas num mais profundo além de si mesmo, queria. Procurava ansiosamente por esse re-encontro e, talvez por isso, inconscientemente, insistia na procura. Recusa o que lhe vem, pois não o satisfaz, porque o que quer, verdadeiramente, é voltar! E, voltando, reencontra o que lhe falta! Assim, sua viagem neste ciclo, já não terá mais fim! E, por uma simples razão: porque não tem destino, pois o destino, afinal, é ele mesmo! Por isso, ao re-encontrar, re-encontra", simultaneamente, a porta do desejo, a intensa ilusão do reencontro, com o que mais amou e perdeu ${ }^{344}$. E, é nesta via que a

Contemporaneidade se constitui, assim, do encontro com o destino do que passa e é ultrapassado. Pois o que passa só está passando, porque é, também,

\footnotetext{
339 Ibidem. p. 46.

340 Idem.

341 Idem.

342 Ibidem. p. 46-47.

343 Direção: Volker Schlöndorff Ano:1991 País:Grécia, Inglaterra, França, Alemanha Gênero: Drama Duração: 117 min. Título Original: Homo Faber Título em inglês: Voyager. Elenco: Sam Shepard, Julie Delpy, Barbara Sukowa, Dieter Kirchlechner, Traci Lind, August Zirner, Deborah Lee-Furness, Thomas Heinze, Bill Dunn.

${ }^{344}$ Idem. 47.
} 
potencialmente o que fica. [...] o mais longínquo é também potencialmente o que vai chegar. E aquilo, cuja permanência é ser ultrapassado, é potencialmente o que mais revela o sentido e o destino da contingência que somos ${ }^{345}$.

Quanto ao individualismo que caracteriza a pós-modernidade, ele denota particular atenção da ética específica deste tempo que se orienta por princípios que fazem do humano uma referência única, essencial e onde a experiência, ou a experimentação do sujeito é aquilo que mais importa. Assim, na pósmodernidade, caem as muitas regras. As normas institucionalizadas passam a um segundo plano e, há uma tendência global de se reduzir as relações autoritárias antes vividas, porque agora, o que conta é o indivíduo, seu bem estar, suas escolhas que prevalecem à tudo o mais, como a referência mais importante ${ }^{346}$.

Pouco acima, William Batista acenava à perda destas referências no colapso do discurso e racionalizações herdadas da racionalidade moderna, que deixaram como herança, para o tempo atual, uma avalanche de crises. Afirmou que isso foi o que fez pessoas tomarem consciência da amplidão do vazio e que a pósmodernidade abriu mão do absolutismo da razão, que não explica tudo ${ }^{347}$.

O racionalismo de Decartes, que o fez afirmar o tão famoso axioma: Penso, logo existo, caracterizou um movimento importante na história da humanidade, aonde se chegou a pensar que através da razão tudo se podia e tudo se alcançava. Inclusive chegar às verdades de valor absoluto. Nesta razão podia-se ultrapassar a força dos sentidos e, alcançar até mesmo as condições transcendentais do mundo. De tal forma o racionalismo se impôs e influenciou a sociedade, que fez uma reviravolta na história chegando, aos diversos campos da Igreja, deste modo o que o racionalismo buscou, sobretudo, foi conhecer a essência. Por isso, não se prendia aos fatos e ao mundo sensível, mas afirmava que a razão humana poderia transcender e chegar ao conhecimento de realidades supra-sensíveis, pela força da abstração e das concatenações racionais ${ }^{348}$.

Com o absolutismo da razão, parâmetros científicos baseados no modelo reducionista e mecanicista se edificaram na ciência e alavancaram novos paradigmas. Em seguida, o idealismo da primeira metade do século XIX,

\footnotetext{
${ }^{345}$ BATISTA, W. Ética e contemporaneidade... p. 47.

${ }^{346}$ Cf. GIOVANETTI, J. P. Psicologia e senso... p. 91.

${ }^{347}$ Por absolutismo da razão entende-se o racionalismo que "tomado apenas etimologicamente, $[\ldots]$ nada mais seria que uma perspectiva cultural pela qual o homem chega às verdades absolutas apenas com o uso da faculdade da razão". Por estar à frente desta corrente Descartes é considerado o "pai do Racionalismo moderno". MORAES, J. M. Uma luz que para uns brilha... p. 7.

${ }^{348}$ MORAES, J. M. Uma luz que para uns brilha... p. 7.
} 
procurou uma interpretação e unificação da experiência mediante a razão. Depois, veio o positivismo de Augusto Comte, que ocupou mais ou menos a outra segunda metade do século procurando investir na experiência mediata, pura e sensível. Com o positivismo, reagiu-se ao idealismo, ao apriorismo e ao formalismo ${ }^{349}$.

Com os dados positivos, descritivos e com a análise objetiva, a ciência foi impondo-se ainda mais respeito. Pode-se obter resultados mais favoráveis e os avanços no campo prático e técnico aplicado multiplicaram-se. Avanços na agricultura, na medicina, na área da microbiologia, profilaxia, no processo de pasteurização, maior esterilização e higiene para a saúde e alimentos ${ }^{350}$. Contudo, se o paradigma newtoniano-cartesiano havia sido útil e necessário para orientar o conhecimento e os caminhos da humanidade até o momento, a partir de agora começa a não dar mais conta das realidades e das exigências dos novos tempos ${ }^{351}$.

Deste modo, a ciência e a sociedade ao se depararem com tamanha particularização, já não podia mais compreender a pessoa como um todo, de forma integrada e unívoca, como um ser de relações, como parte do meio em que vive. E, nem bem chegou o século $\mathrm{XX}$, as incoerências apareceram, as dificuldades do novo paradigma se esvairam por conta das intensas ramificações, porque a ciência, de tão especializada, começou a se fragmentar sempre mais. Com o despertar da consciência se procurou dar lugar às outras interpretações do mundo, que não fossem dentro do modelo reducionista. Desta forma questiona-se: o que faltou ao modelo anterior? Com certeza, a percepção mais aguçada de que

[...]o universo material é visto como uma teia dinâmica de eventos interrelacionados na qual nenhuma das propriedades de qualquer parte dessa teia é fundamental: todas resultam das propriedades das outras partes e a consequência global das suas inter-relações determina a estrutura de toda teia ${ }^{352}$.

Dado a sociedade estar em outro momento, a razão não ter sido onipotente, o esfacelamento do humano sentir-se por todos os espaços, percebe-se que

O pensamento mecanicista encontrou seus limites no início do século XX. Uma nova forma de pensar fez-se necessária e ela necessitava ter características

\footnotetext{
${ }^{349}$ Cf. COSTA, D. Fundamentos para o estudo da estratégia nacional. Rio de Janeiro: Paz e Terra, 2009. p. 117.

${ }^{350}$ Cf. CAPRA, F. O ponto de mutação... p. 130.

${ }^{351}$ Cf. OLIVEIRA, E. G. Educação à distância na transição paradigmática. Campinas: Papirus, 2003. (Coleção Magistério: Formação e Trabalho Pedagógico) p. 24.

${ }^{352}$ CAPRA, F. A teia da vida... p. 48.
} 
especiais para compreender os novos fenômenos complexos diante dos olhos dos cientistas e das pessoas em geral na vida prática ${ }^{353}$.

De modo, que por todos os lados, inicia-se esta busca: na física, campos de força eletromagnéticos fizeram cientistas repensar estratégias e adequarem-se à nova realidade; Einstein cria a Teoria da Relatividade e, com o desenvolvimento da física quântica, faz-se necessário mudar conceitos e reformular definições.

Isso sem falar que, em meio a este tempo, se a fé, a mística e a religiosidade popular já tinham sido alvos para muitas contendas com o racionalismo, imaginese, então, após os mestres da suspeita: Freud (ilusão), Marx (ópio do povo) e Nietszche (a morte de deus). Ali, junto ao fenômeno religioso a crítica não foi poupada. E, de questão em questão, como ao efeito dominó, não só se questionou e se incitou pessoas a pensarem e a suspeitarem do que está por trás de tudo, como também se desacomodou muita gente ${ }^{354}$.

A partir destes mestres da suspeita, deu-se um salto neste novo tempo, pois com Descartes, podia se duvidar do modo como as coisas apareciam, mas ainda não se chegava a duvidar do modo como a consciência aparecia em si mesma. A partir deles, “começa-se a duvidar, entretanto, da própria consciência",355. Por essa razão a pós-modernidade, tráz o paradigma holístico, carregado da necessidade improrrogável de maior integração e maior síntese. Porque este novo paradigma

valoriza a síntese; pretende uma visão orgânica, ecológica, totalizante sobre os fenômenos estudados. No lugar de se concentrar nas partes, como o faz o método mecanicista, que a tudo desmancha, estuda e remonta, uma visão sistêmica do mundo, se concentra nas relações entre os elementos e na interdependência deles entre si, deles e o todo e entre os mais variados fenômenos do Universo com o cosmo ${ }^{356}$.

Isso faz compreender melhor porque Fritjof Capra, na obra $O$ ponto de mutação refere-se a essa mudança de paradigmas, como um processo subsequente das mudanças da sociedade. Pois, depois de tanto fragmentar-se, a sede de síntese faz-se natural e inevitável. Por isso, a ciência contemporânea, particularmente explica como a física quântica se aproximou das doutrinas orientais milenares. Capra serve-se do exemplo do tao e da movimentação do yan e yang, para mostrar

\footnotetext{
${ }^{353}$ ANDRADE, A. L. O que vem a ser sistêmico. In: ANDRADE, A. L. (Org.) et. al. Pensamento sistêmico: caderno de campo. O desafio da mudança sustentada nas organizações e na sociedade. Porto Alegre: Bookman, 2006. p. 43.

${ }^{354}$ JORGE, J. S. Cultura religiosa: O homem e o fenômeno religioso. 2. ed. São Paulo: Loyola, 1998. p. 15.

${ }^{355}$ DOMINGUEZ MORANO, C. Crer depois de Freud... p. 28.

${ }^{356}$ MORAES, J. M. Uma luz que para uns brilha... p. 7.
} 
a importância de ambos no entrelaçamento dos opostos, não contudo à feição da cultura ocidental, assim:

$\mathrm{Na}$ concepção chinesa, todas as manifestações do tao são geradas pela interação dinâmica desses dois pólos arquetípicos, os quais estão associados a numerosas imagens de opostos colhidas na natureza e na vida social. É importante e muito difícil para nós, ocidentais, entender que esse opostos não pertencem a diferentes categorias, mas são polos extremos de um único todo. Nada é apenas yin ou apenas yang. Todos os fenômenos naturais são manifestações de uma contínua oscilação entre os dois pólos. Todas as transições ocorrem gradualmente e numa progressão ininterrupta. A ordem natural é de equilíbrio dinâmico entre o yin e ou yang ${ }^{357}$.

Assim, Capra refere que para os orientais, os opostos não são inevitavelmente bons/ruins, claro/escuro, branco/preto, mas, ao contrário tanto um lado, como outro, necessários ao equilíbrio humano, da natureza, do cosmos. Neste sentido "o que é bom não é o yin ou o yang, mas o equilíbrio dinâmico entre ambos, o que é mau, ou nocivo é o desequilíbrio entre os dois" ${ }^{358}$. Esta necessidade de encadeamento gera a necessidade de interação que humanidade, também a mística e o fenômeno religioso deste tempo, estão a buscar.

Ora, tudo isso, traz implicações visíveis para o fenômeno religioso e para as religiões. Se o paradigma reducionista facilitou toda uma construção científica de uma teologia sistemática, o paradigma holístico vai dar preferência a um contato direto e imediato com a divindade, sem necessidade de outras vias que não o próprio indivíduo e a própria divindade que se manifesta nele e no mundo ${ }^{359}$.

Assim, de fato, em suma, pode-se ficar com este pensamento: a razão não teve, não tem e não terá a explicação para tudo. Por mais que seja importante sobressair-se no humano, há sempre um espaço aberto, onde talvez, por esta brecha pode se entrever o mistério. Neste sentido, é que a humanidade enseja novos paradigmas, orientando-se às novas buscas. Nessa linha também, pode-se falar da "Nova Era", desse movimento que existe já em torno de uns 50 anos e que alguns especialistas indicam com a data provável de nascimento, o ano de $1962^{360}$. O movimento compila em si diversas expressões, antigas e novas e que, algumas vezes, inclusive, parecem irreconciliáveis. Não é uma religião, mas pode dizer-se uma expressão cultural religiosa, ou um movimento social/religioso.

${ }^{357}$ CAPRA, F. O ponto de mutação... p. 33.

${ }^{358}$ Idem.

${ }^{359}$ MORAES, J. M. Uma luz que para uns brilha... p. 7.

${ }^{360}$ BARREIRO, A. Buscar a Deus e encontrar-se em Deus: Como orar no mundo de hoje. São Paulo: Loyola, 1995. p. 27. 
Alguns denominam ao fenômeno como Era de Aquário, em comparação à Era de Peixes que foi o tempo de Jesus Cristo (Cristandade/Cristianismo). A Era de Aquário, é a que suplantaria e postergaria o Cristianismo procurando ver, encarar e viver a vida, num novo olhar paradigmático ${ }^{361}$.

"Nova Era", "New age", "Era de Aquário" são termos que indicam esse movimento que olha para a frente, com saudade do passado[...]. o termo "Nova Era" remonta assim à esotérica Alice Bailey, o seu significado [...]Está ligado à concepção de Jung sobre as passagens de época para época, a partir das "coisas que se vêem no céu". A idade de Aquário é vista, portanto, como a Era cujo elemento é o Ar e cujos planetas governantes são Saturno e Urano. E, enquanto Saturno indica mais a estagnação e a inércia, Urano indica a mudança, a transformação, o progresso, a consecução de um novo estado avançado de desenvolvimento da consciência. [...] a Nova Era é "um termo guarda-chuva" capaz de recolher tudo e o contrário de tudo: Saturno e Urano juntos ${ }^{362}$.

Segundo Aldo Terrin, a tese nuclear da Nova Era precisa ser enfatizada. Sua sensibilidade religiosa distingue-se de todos os outros movimentos que possuem uma fisionomia e doutrina mais definida ${ }^{363}$. Para o autor, a primeira coisa que precisa se reconhecer nesse fenômeno religioso é que a Nova Era coloca em evidência a intuição, a experiência, a espontaneidade natural e um romantismo no qual Deus e o mundo confundem-se. Em segundo lugar, é importante entender que no modo de ver da Nova Era, em tudo há um horizonte aberto, cujo limite é o não limite da própria consciência. Em terceiro, que há uma nova sensibilidade religiosa que se configura por meio de uma dinâmica de superação de todos os limites, até atingir o holon, a totalidade, a plenitude. A experiência é feita para se expandir, superar, até chegar-se à compreensão holística global de toda a realidade e, assim, "metamorfosear" a consciência. É preciso sair dos limites da percepção sensível e captar outros mundos, outros espaços ${ }^{364}$. Nesse entendimento,

a Nova Era não é a religião cristã [...]. Por isso não se pode impor a ela uma vestimenta que não lhe seja adequada. Se quisermos nos perguntar sobre o seu significado, será preciso isolar o fato de que esse movimento não valoriza a história, como o faz o cristão em nome de Cristo. Todavia, numa época em que a indiferença religiosa e a apatia pelas religiões chega às raias do ateísmo mais grosseiro e à perda de todo horizonte de valores, é importante reconhecer esse âmbito de religiosidade positiva e otimista; é significativo e importante valorizar algumas de suas dimensões, que são próximas à realidade cristã e dão

${ }^{361}$ BARREIRO, A. Buscar a Deus e encontrar-se em Deus... p. 27.

362 TERRIN, A. N. Nova Era: a religiosidade do pós-moderno. São Paulo: Loyola, 2006... pp. 1516.

363 Ibidem. p. 19.

${ }^{364}$ Ibidem. p. 18. 
possibilidade de dialogar com o mundo em seu caminho histórico-cultural atual $^{365}$.

E sob este ponto fenomenológico, mostra Terrin que a religião sempre foi filha do romantismo, pois "nasce da maravilha, do maravilhoso, do poético, como nos ensina a história das religiões"366. O mundo necessita desse novo "encantamento" 367 . Entretanto para o autor, a nova religiosidade não deixa de ser narcisista e ingênua e, a cultura deste tempo: da yoga, do yogurte, da bike, da macrobiótica, traz as angústias e necessidades próprias do tempo atual ${ }^{368}$. Assim,

O homem hodierno - como aparece também na Nova Era é um sujeito que necessita ser protagonista para vencer o seu isolamento, e que não se contenta com doutrinações e teorias, as quais lhe permitem de maneira alguma superar seus estados de desânimo e de solidão. Quando pratica yoga, é ele que age em primeira pessoa. Todas as técnicas psicossomáticas são exercidas diretamente pelo sujeito. Do mesmo modo tem necessidade de orar com suas palavras e de ser ele o interlocutor com o divino. As orações feitas pela pessoa, em que cada um se torna sujeito ativo, são muitas vezes um remédio infalível, um sacramental de grande valor para a realização da pessoa ${ }^{369}$.

Isso pode ser considerado um aceno à liturgia cristã para que invista mais na valorização da pessoa, uma vez que a emergência da experiência religiosa liga-se à vontade de ser protagonista, à essa apropriação do fato religioso ${ }^{370}$. Além disso,

Também o homem de hoje sente a necessidade de dialogar com a natureza; sente a necessidade de redescobrir o verde, os campos, os montes, o mar e as estrelas do céu. Mas por quê? Porque tem uma nova consciência ecológica, mas também porque sente a necessidade irreprimível de uma deep ecology, que equivalha a uma nova limpeza espiritual, a uma catarse mística ${ }^{371}$.

Assim, o que se percebe nessa mudança de paradigma em relação à mística, à fé e à religiosidade é uma mudança na concepção de Deus, também. Daquele deus que estava em voga no Ocidente. Do deus da Idade Média, aterrorizante, terrível, do deus da Escolástica dos manuais de teologia dogmática, das leis, dos silogismos perfeitamente compilados que não foi suficiente para o coração humano. Assim, o deus (ou a imagem distorcida de Deus), passada através da razão, não chegou a ser totalmente Deus. Faltou-lhe uma maior proximidade com o Deus Vivo, presente no Mistério, no próximo, no amor, na maternidade, na

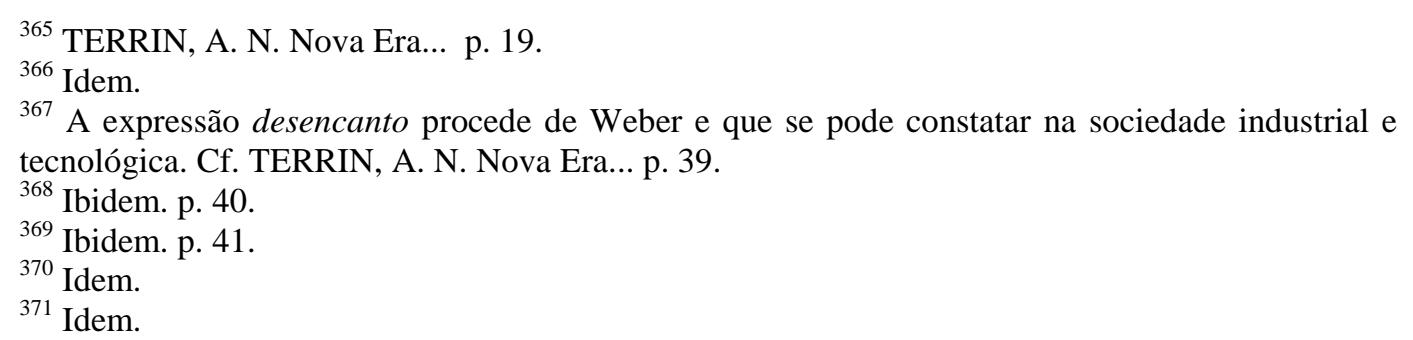


doação, na capacidade de estar presente à sua filiação e de interagir com a pessoa. Outro movimento que se pode enquadrar no estudo dos fenômenos religiosos é o pentecostalismo, que surge com John Wesley que desejava um processo de avivamento e de santificação para uma vida cristã mais autêntica ${ }^{372}$.

A partir de meados da década de 1970, diferentes movimentos religiosos cristãos e não cristãos vem intervindo na esfera social e política, implementando propostas de "recristianização", "rejudaização" e "reislamização" da sociedade. Todos esses movimentos têm projetos de reconstrução do mundo que buscam nos textos sagrados as regras da sociedade de amanhã $\tilde{a}^{373}$.

O pentecostalismo surgiu no seio da Igreja Metodista protestante, com John Wesley no fim do século XIX, nos Estados Unidos, concomitante a outros movimentos da época como o fundamentalismo, o milenarismo e o evangelicalismo. Sentiu a profunda secularização da sociedade capitalista e desejava contribuir com explicações sobre a realidade, sobre o humano, sobre a vida, a religião, a Bíblia. Lutava contra a consequente dessacralização do mundo, da pessoa e contra a expansão da já denominada teologia da libertação. Salientava a importância do Espírito Santo: batismo no Espírito, dom de línguas, curas, carismas em geral.

Típica do pentecostalismo é a afirmação da necessidade de um segundo batismo o "Batismo no Espírito Santo" que possibilitaria a experiência dos dons do Espírito, mediante manifestações carismáticas, sobretudo o dom de línguas e a cura divina. Caracteriza-se também por uma profunda piedade individual, uma moral rígida que se manifesta inclusive no modo de vestir e de cortar o cabelo. O culto possui uma aparente espontaneidade, embora não seja algo improvisado, mas obedece a um esquema fixo. Nele, dão-se sempre "testemunhos" de pessoas presentes ${ }^{374}$.

Os grupos de pentecostais ressaltam a oração de louvor, o compromisso moral individual, tem apreço pelo carismático e, de um modo geral, respeito pela autoridade da Igreja ${ }^{375}$. São mais conservadores em relação às inovações na Igreja.

As comunidades pentecostais apresentam, geralmente, uma atitude conservadora em relação às questões sociais, embora não faltem exemplos contrários. Por outro lado, pode-se dizer que, no seu conjunto, o pentecostalismo permanece afastado do movimento ecumênico e que manifesta uma consciência de forte exclusivismo eclesiológico. Não faltam, porém, também neste ponto algumas exceções ${ }^{376}$.

\footnotetext{
${ }^{372}$ DALGALARRONDO, P. Religião, psicopatologia... p. 119.

${ }^{373}$ DIMENSÃO BIBLICO-CATEQUÉTICA ARQUIDIOCESE DE SÃO PAULO. O fenômeno religioso: diálogo entre diferentes. São Paulo: Loyola, 1997. p. 51.

374 HORTAL, J. (S.J). E, haverá um só rebanho: história, doutrina e prática católica do ecumenismo. 2. ed. São Paulo: Loyola, 1989. p. 88.

${ }^{375}$ Cf. DALGALARRONDO, P. Religião, psicopatologia... p. 119.

${ }^{376}$ HORTAL, J. (S.J). E, haverá um só rebanho... p. 88.
} 
O pentecostalismo denominacional, diferencia-se do que se denomina de neopentecostalismo. Este

começou após a Segunda Guerra Mundial nas Universidades norte-americanas e espalhou-se no seio das Igrejas históricas. Os neopentecostais - que na Igreja católica romana assumiram o nome de "Renovação Carismática Católica" insistem, como o pentecostalismo denominacional, no conceito de batismo no Espírito Santo e nos carismas extraordinários, principalmente no dom das línguas e na cura divina. Enquanto os "carismáticos" católicos convivem harmoniosamente no seio da Igreja, os neopentecostais de algumas denominações protestantes históricas provocam a rejeição de parte das autoridades de suas respectivas comunhões, chegando-se em, alguns casos, à formação de novas denominações ${ }^{377}$.

O imaginário coletivo desses grupos comporta o entendimento de que os espíritos agem livremente no mundo e que satanás e seus demônios são os responsáveis por toda sorte de males que existe no mundo e na vida pessoal do crente $^{378}$. Conforme Libânio, estes grupos prestam-se ao uso ideológico e à interesses políticos tanto nacionais, como internacionais, assim,

$\mathrm{O}$ crescimento de grupos religiosos fundamentalistas, pentecostais e neopentecostais na América Latina vem sendo estudado em relação com a ofensiva neoconservadora norte-americana no campo da política, e eclesiástica nos espaços religiosos. Política e religião se vinculam pelo uso ideológico que interesses políticos internacionais e nacionais fazem dos grupos religiosos, financiando-os. Entram, portanto, na estratégia neoconservadora ${ }^{379}$.

Contudo, importa aqui para esta pesquisa não uma análise do significado disso para a sua atuação prática, mas compreender como estes fenômenos são em sua essência uma manifestação concreta e visível dessa angustiante e intensa busca de Deus. Assim pode-se ver que a experiência religiosa proporcionada e realizada tanto pela Nova Era, como para o pentecostalismo traz intrinsecamente em sua busca a necessidade de maior acolhida, de maior intimidade e imanência para com o transcendente. Desprendem-se dos livros e dos manuais e procuram a manifestação afetiva para dialogar diretamente com o ser superior. Com isso podem até suprimir o que tradição das Igrejas considerou fundamental para uma experiência de comunhão com o Deus da Vida.

Neste sentido, a Nova Era e o pentecostalismo chegam a conviver com os fenômenos extraordinários, dos quais se falou no segundo capítulo. Uma leitura

\footnotetext{
${ }^{377}$ Idem.

${ }^{378}$ Cf. MORAES, J. M. Uma luz que para uns brilha... p. 7.

${ }^{379}$ LIBANIO, J. B. Os carismas na Igreja do Terceiro Milênio: Discernimento, desafio e práxis. São Paulo: Loyola, 2007. p. 190.
} 
possível de se fazer é considerar essa convivência no sentido de uma tentativa, de colocar Deus mais próximo de si e da experiência de vida. Ou seja, a necessidade de se encontrar Deus mais ao alcance do humano. Assim, nota-se que

Nova Era e pentecostalismo nasceram como reação ao formalismo e autoritarismo de igrejas e experiências religiosas tradicionais e dogmáticas, e [...] tanto um como outro, vê um mundo espiritual interagindo largamente com o nosso mundo temporal através de espíritos - sejam os espíritos guias, ou os anjos e demônios. Enfim, ambos são, em última instância, expressão da reação à fragmentação que a modernidade trouxe à sociedade e também à religião ocidental $^{380}$.

Percebe-se, inclusive, a possibilidade de diálogo entre Nova Era e pentecostalismo, dado suas semelhanças. Assim, um movimento tem muito a ensinar e a aprender com o outro, sobretudo, no que diz respeito à prática do evangelho, uma vez que o Evangelho está aberto à todas as culturas e, em todos os tempos e lugares, a palavra de Deus necessita ser anunciada aos confins da Terra.

Em síntese, a pós-modernidade é a continuação da modernidade com um jeito singular de se expressar e de se caracterizar. Revela-se como um tempo onde aparecem as fragmentações, as desconstruções, as indetermanências que, no dizer de Iahb Hassan, influenciam as ideias, o saber e as ações da sociedade.

Contemporaneidade é não se ter paradigmas, é ruptura, é crise de totalização, é viver a aporia entre o sujeito e o social é descobrir-se sempre de novo, não realizando-se nunca. É o reencontro numa nova viagem, como no filme O viajante e, numa busca de abertura oca para a potencialidade infinita, no dizer de William Batista ${ }^{381}$. É contemporaneidade, é individualismo e viagem também no sentido de deixar cair regras e dogmatismos, apropriando-se como sujeitos de uma referência nova, fundamental. Na contemporaneidade é tempo de abandonar o absolutismo da razão. As inúmeras fragmentações da ciência dão a entender que hoje há maior necessidade de síntese, de integração, de uma visão holística e sistêmica. Por isso, considera-se nelas um tempo de mudança de paradigmas. $\mathrm{Na}$ contemporaneidade descambam-se as muitas expressões da religiosidade e dos fenômenos religiosos, particularmente, aqui apontados, como próprios da Nova Era e do Pentecostalismo. É onde o extraordinário começa a ser vivido como ordinário e onde a sede pelo transcendente, pela vida mística, pela

\footnotetext{
${ }^{380}$ Cf. MORAES, J. M. Uma luz que para uns brilha... p. 7.

${ }^{381}$ Filme "O Viajante", de Volker Schloendorff, baseado no livro "Homo Faber", de Marx Frish.
} 
experimentação e autonomia do sujeito mostram-se mais visíveis, mais sensíveis e indispensáveis. Contudo é aqui, neste tempo, também, que a busca pela palavra e pela prática do Evangelho tornam-se profundamente atuais e podem tornar-se caminho para maior reorganização da necessidade e dos valores e ainda trazer $o$ Deus da vida mais próximo do humano, saciando um pouco da sede do infinito que a sociedade de hoje tanto manifesta.

\section{5}

\section{CONCLUSÃO}

A intenção deste capítulo foi dar uma visão geral de algumas premissas básicas para, no próximo, perceber melhor como é que se dá o olhar da psicologia para a mística e, particularmente, para a mística teresiana.

Três aspectos nesse capítulo são fundamentais. A abordagem e algumas expressões específicas da psicologia; alguns elementos que caracterizam o tempo atual e, a forma como a sede pela mística se manifesta na atualidade.

Quanto ao primeiro aspecto, referente à abordagem e às expressões peculiares da psicologia, pode-se destacar aqui a valiosa contribuição de Freud, esse gênio, como salientou o texto, a personalidade científica do milênio que passou. Quem seria hoje capaz de desdizer Freud? Assim como, também, quem será hoje capaz de dizer algo que desabone a conduta de Teresa de Ávila? Ambos foram pessoas muito à frente de seu tempo e tiveram algo substancial a dizer para a humanidade. O recado foi dado. E serviu para organizar, ou reorganizar a vida de tantos acrescentando significativamente, ao acervo cultural da humanidade. E, já não dizia o ditado popular que Freud explica?! Explica mesmo. E, não se diz nos ditos que a voz do povo é a voz de Deus?! E também que o povo sempre tem razão. Assim é possível confiar nos dois ditados populares e crer em Deus e, também no Freud. Ora, foi Deus quem deu a razão à Freud e ele serviu-se dela para ajudar a muitos. É preciso ouvir ao Freud, suas teorias tem um valor importantíssimo. Mas mais do que elas, a personalidade de Freud parece ter tanta originalidade, tanta verdade e profundez, características que no fundo que se afinam com o cristianismo. Sua busca, de ir atrás do sentido das coisas, de poder aproximar-se da significação que colocou em seus escritos falam da grandeza do que está para além do que se vê e da elevação desse cientista, investigador. Foi 
atrás das respostas para as questões que formulou e sua seriedade e postura profissional, sua herança, deixam ao mundo algo que pode fazê-lo melhor.

O fundador da psicanálise empenhou seu tempo e juventude refletindo sobre a religiosidade. Também foi influenciado pelo absolutismo da razão, pois em sua época isso era o que mais contava. Contudo, por seu contexto e do seu jeito, Freud buscou a Deus. Talvez de um modo tão inconsciente, quanto a própria descoberta que fez deste Totalmente outro, como depois o denominará Lacan.

Em Freud, como nos autores que o sucederam, pôde se perceber que as leis, doutrinas e os princípios das religiões, enquanto conjunto de valores, são referenciais importantes para nortear a pessoa em relação à vida, à organização pessoal e à troca social. Elas colocam-se a serviço da própria humanização para que o sujeito se humanize e se eleve, pois espiritualizar-se é, antes de tudo, tornar-se ainda mais humano. Reportando-se ao Ser dos seres, o absoluto, primordial, infinito e eterno, o ser humano encontra o sentido original e originante de si mesmo. Deste modo, a teologia entende porque Cristo se encarna. Justamente para que o humano encontre nele "a medida, a altura, a largura e a profundidade" da sua humanização, do quanto pode amar as pessoas e a Deus ${ }^{382}$. E, por isso também, a teologia percebe que para pensar Deus é preciso pensar no humano. Pois, o Deus que se encarna no humano, está também na voz do povo que sofre e que espera por maior libertação.

Deste modo, na encarnação de Cristo, compreende-se melhor o quanto a humanidade, o sujeito humano de que os autores falam é importante para Deus! É preciso estar atento a este humano e ouvir o seu discurso, suas necessidades. A fé cristã, tem uma peculiaridade particular para essa escuta e traz em sua essência e em sua história a presença de Cristo que caminha entre os seus. Por este motivo, a teologia leva a sério a missão de ser profeta e de continuar a anunciar algo que ao cristianismo foi revelado e preservado, ao longo de tantos anos, através da tradição. Deste modo a fé do tempo presente, não é vazia, oca, mas plena de significado para os que crêem, dado comportar o potencial que se encontra no mais íntimo do humano, ali onde também mora Deus, como dirá Teresa.

Em Lacan pela via da linguagem os significantes também organizam a vida e o modo de pensar do sujeito. O eu de Lacan refere-se ao desconhecimento,

382 Cf. Ef 3,18. 
alienação (sede do narcisismo) e pode ser associado às primeiras moradas de Teresa. O inconsciente de Freud liga-se ao mais íntimo de si, onde mora Deus, de Teresa. Talvez, no inconsciente, encontre sua morada como também acenará Jung.

No aspecto de desamparo fundamental sobre o qual Freud referia-se, ao falar do ser humano na busca do transcendente, Lacan se expressa visualizando o sujeito como um ser da falta. Para ele a pessoa constitui-se, enquanto sujeito, tendo a consciência de si mesma a partir do Outro, ao qual denomina o gozo do Outro. Em Lacan a capacidade de ser sujeito, de poder ser diferente do que se é, não depende da pessoa, mas dos outros, dado viver dentro de uma cultura, na qual se faz os laços sociais. Neste meio, o sujeito assimila significantes e abandona máscaras firmando-se cada vez mais como sujeito frente a si mesmo. A alienação aponta ao sintoma e quem se aliena ao campo do outro, mostra vedar para si o agir espontâneo, não conseguindo por suas limitações, apropriar-se da cultura adequadamente, temática que tem proximidade similar aos escritos teresianos.

Um aspecto importante acenado por Vergote é o limite da psicologia que, como ciência, depara-se com o limite da teologia. Ora, perceber-se em seus limites é condição fundamental para a aproximação e diálogo, para deixar-se questionar e se re-pensar ante conceitos formulados, construídos.

A psicanálise de Jung deu passos largos em relação à mística. Aproximou-se da doutrina de Teresa, sobretudo pela sua visão de conjunto, integração e pela necessidade de síntese da contemporaneidade. O inconsciente junguiano mostra as múltiplas conexões com os ancestrais, dos significados e das experiências passadas e presentes nos acontecimentos que marcaram a história da humanidade.

Freud e Reich conseguem enxergar o lado mais obscuro da religiosidade no sentido do patológico do movimento e da forma de se expressar em relação ao transcendente, pois criam estes, dependência, opressão, alienação e desumanização. Contudo, o que vêem nos cristãos é o que se pode ver também no sujeito não cristão, porque a patologia aparece no humano, não é a condição fundamental e nem se centra na essência da religiosidade. De qualquer forma, como diz Paul Ricoeur, com eles, os psicanalistas e outros críticos da religiosidade, a fé só tem a lucrar. Pois, para a desmistificação e análise, a contribuição da psicologia torna-se bem vinda, oportuna, adequada e eficaz, dado essa ciência qualificar-se em sua capacidade de ver, de ouvir e de perceber. O 
instrumental que lhe cabe às mãos é útil e torna-se ferramenta eficaz, ao alcance da teologia, da mística e dos cristãos.

Na obra de William James, de Bion, de Jung e no entendimento de Lacan, o desenvolvimento da mística, de sua compreensão pelo âmbito da psicanálise foi basilar no que se refere à integração da esfera religiosa, enquanto subjetividade pertencente ao sujeito. Isso mostra o quanto a teoria desses autores pode contribuir aos novos investimentos acadêmicos que levam em consideração da ciência, a experiência da religiosidade, da mística e a condição de quem crê.

Quanto aos elementos que caracterizam o tempo atual e à forma como a sede pela mística se manifesta, na atualidade, destaca-se aqui o amplo sentido da busca de algo que ainda falta. No sentido de Rahner, por tudo o que se viu aqui, o texto não evidencia que o homem do futuro não será nada, mas deposita uma confiança fundamental na qual as pessoas de hoje e do futuro serão, de fato, místicas! É neste sentido também que o tempo contemporâneo demonstra o quanto o ser humano é pro-jedum enquanto incompleto, inacabado e histórico, que está se fazendo ainda e pro-jeto no sentido de consciência, de lançar-se, numa abertura para o futuro, para o outro, para Deus.

Os autores usados auxiliaram a tomar-se consciência da amplidão do vazio, e da incessante busca por respostas e de um novo tempo esperado pela pósmodernidade. Em Capra, visualiza-se este, num novo modo de integração necessária à vida, aonde não se salienta nem o bom, nem o ruim, mas o equilíbrio dinâmico entre os opostos. O paradigma holístico mostra-se com capacidade de responder ao apelo de dialogar com o mundo em seu caminho histórico-cultural.

O sentimento de autonomia e de pertença, nas diferentes comunidades eclesiais, a acolhida e a solidariedade fundamentadas na Pessoa, na vida e na obra de Cristo, são caminhos para não se procurar na emoção, no irracional, no sentimentalismo $\mathrm{O}$ que e está para além de tudo isso. É importante ver que, ao longo da história a imagem de Deus muda, mas a essência da fé permanece. Neste sentido a ilusão a que Freud acenava, para o cristão tem o nome de esperança, uma vez que se espera e se aguarda em Deus, naquele que é a essência da Verdade, a essência do Caminho e a essência da Vida (cf. Jo 14). Assim, de outro modo o Deus Vivo apresenta-se, neste tempo e segue no mistério da vida, no próximo, no amor, na maternidade e nos encontros e reencontros existenciais. 


\section{4 \\ OLHAR DA CIÊNCIA E DA PSICOLOGIA SOBRE A MÍSTICA DE TERESA}

\section{1}

\section{Introdução}

Nos capítulos anteriores pôde-se falar sobre essa personalidade Teresa de Ávila, sobre o que significa a mística e como a ciência, a psicologia e a mística se inter-relacionam, neste tempo hodierno sedento pelo misticismo. No capítulo anterior, pôde se visualizar mais proximamente as premissas para o presente capítulo. E o atual capítulo procura compreender, o suposto olhar da ciência e da psicologia sobre a mística de Teresa de Ávila, em seus primórdios e na atualidade.

Que respostas podem ser dadas aos enquadramentos de alucinação, histeria, loucura, epilepsia e aos outros, que recebeu Teresa ao longo da história? Como a Igreja e a Teologia a consideram e como se posicionam diante das críticas recebidas? Pode Teresa ter tido algum reconhecimento para além da Igreja, também no mundo científico? Como foi sua reputação e acolhida nos primórdios da ciência da psicologia nascente? Como hoje se vê o diálogo entre a psicologia e a mística? Que tipo de abordagens podem ser feitas a partir de suas obras?

O presente capítulo levanta alguns destes questionamentos e se propõe a dar pistas de caminhos, ou entendimentos possíveis em relação à estes.

\section{2}

\section{A Mística de Teresa vista pela ciência e psicologia em seus primórdios $^{383}$}

Este ítem mostra como a ciência e a psicologia, em seus primórdios, olharam para Teresa. Traz um acontecimento de sua vida póstuma, relacionado à Escola de Charcot, em meio ao tempo em que Charcot renomava-se como o mais

${ }^{383}$ Todo este ponto tem como base da sua reflexão e da sua redação a obra do grande teresianista: ALVAREZ, T. Teresa a contraluz. La Santa ante la crítica. Burgos: Ed. Monte Carmelo, 2004. O resumo e a tradução nos quatro idiomas da obra (espanhol, latim, francês e italiano) foram feitos pela autora da tese. 
eminente neurólogo do século XIX, com suas pesquisas em altíssimo prestígio ${ }^{384}$. O episódio deu-se por ocasião do concurso do III Centenário da morte de Teresa entre os anos 1582 a 1882, na Espanha.

A partir desse e da sua produção literária, Teresa é levada ao teatro, à novelística, às Artes, ao cinema, à literatura e é colocada sob o olhar da ciência e da psicologia, ponto que, aqui, recebe relevo. Desde a polêmica despertada neste III Centenário teresiano, houve diferentes posicionamentos a favor da doença e contra Teresa e sua doutrina, como, também, a favor de Teresa e de sua doutrina e mística. O diálogo entre opositores e defensores, elevou o nível de curiosidade em relação à vida da santa e trouxe um entendimento mais amplo de sua existência, de sua mística, do que aconteceu na realidade e no contexto de Teresa de Ávila.

Neste ítem, também se pode compreender melhor como a histeria repercutiu na psicologia nascente e em Charcot: na grande histeria, na histeria menor, nos fenômenos sobrenaturais e psicológicos e, ainda é possível ver como soam à teologia e à psicologia os fenômenos místicos da vida de Teresa.

\subsection{1}

\section{Ponto de partida (Pe. Hahn, no terceiro centenário da morte de Teresa)}

Como já acenado acima, pelo que se encontrou até o momento de pesquisa, o primeiro olhar da psicologia em relação à mística de Teresa deu-se a partir de um amplo concurso realizado na cidade de Salamanca, na Espanha, na ocasião do III Centenário de seu nascimento. A memória premiada nesse concurso foi o estudo realizado pelo cientista Padre Guillermo Hahn, (S. J), com o título: Os fenômenos histéricos e as revelações de Santa Teresa. Nesta época, entre 18801882, Charcot trabalhava em Paris, no famoso hospital universitário de $L a$

\footnotetext{
384 Jean Martin Charcot nasceu em Paris. Orientou-se à medicina com a ajuda de Pierre Rayer, médico pessoal do Imperador Napoleão III. Seu nome é inseparável da história da histeria, da hipnose e origem da psicanálise. Foi médico e professor no Hospital de Salpétrière. No auditório do hospital todas as terças-feiras apresentava o resultado de suas pesquisas. Foi o último representante da primeira psiquiatria dinâmica e rival de Hippolyte Bernhein. Teve um papel fundamental na formação do jovem Sigmund Freud, que assistia maravilhado às suas lições e demonstrações clínicas na Salpétrière entre outubro de 1885 e fevereiro de 1886. Cf. ROUDINESCO, E. Charcot, Jean Martin. In: ROUDINESCO, E. et. al. Dicionário de psicanálise... p. 109.
} 
Salpêtrière, onde fazia e apresentava, para um grande auditório suas pesquisas. Atuava tanto como médico, como professor na Faculdade de Medicina ${ }^{385}$.

Em 1880, dois anos antes do III Centenário da morte de Teresa (15821882), para seu maior brilho e realce, organizou-se o concurso, com o título de: Evento Literário e Artístico. Seus organizadores foram dois insignes teresianistas da época: o bispo da cidade que se chamava Monsenhor Narciso Martinez Isquierdo, conhecido por bispo de Santa Teresa e o Padre Enrique de Ossó y Cervelló (1840-1896) ${ }^{386}$. Além deles, havia uma comissão executiva composta por seis profissionais competentes. Em junho de 1881, o concurso se difundiu por toda a Espanha e, também no exterior, com o programa do evento. Admitiam-se nele tanto as versões populares, como as altas especializações e as obras deveriam ser apresentadas até o dia 31 de julho de 1882. A agenda foi concluída com 18 títulos de estudo, divididos nas quatro seções:

1 Estudos sobre a personalidade de Teresa;

2 Sobre a obra da fundadora e reformadora;

3 Sobre Teresa escritora e cada uma de suas obras;

4 Sobre a pastoral teresiana (que no tópico 18, chegou a propor Arquitetura: projeto de um templo, onde seria conveniente, colocar o túmulo da santa, tanto em relação à igreja, como ao convento).

Os temas da primeira sessão eram importantes. Correspondiam aos prêmios mais elevados e estavam formulados em tom polêmico (típico do momento histórico espanhol). Tratavam de reivindicar o valor da experiência mística de Teresa, contra as recentes interpretações racionalistas e naturalistas. Destacavam-se, nesta sessão os temas da distinção entre o natural $e \quad o$ sobrenatural na experiência mística e os que afirmavam a origem sobrenatural de

\footnotetext{
${ }^{385}$ Hospital Pitié-Salpétrière, famoso hospital universitário, pertencente hoje, à Universidade de Paris Cf. SANTUCCI, J. Mulheres Médicas: As pioneiras da medicina. Rio de Janeiro: Ediouro, 2005. p. 125.

${ }^{386}$ Enrique de Ossó y Cervelló, nasceu 16 de outubro, 1840 em Vinebre, Espanha, na diocese de Tortosa. Seu ideal era fazer grandes obras para a Igreja. Era o caçula dos três filhos de Jaime de Ossó e Micaela Cevelló, casal muito cristão. Ordenou-se sacerdote em setembro 1867. Em 1876 fundou a Congregação das Irmãs da Companhia de Santa Teresa (Irmãs Teresianas). Faleceu em 27 de janeiro de 1896. Beatificado em 14 de outubro de 1979, pelo Papa João Paulo II, canonizado santo em 16 de junho de 1993. O Santo Padre declarou Enrique de Ossó modelo adequado para catequista do século XXI. E a Igreja celebra sua festa em 27 de janeiro. Cf. MARY THERESE, S. Heroes and heroines Canonized in the twentieth Century: Book II (1951-1999). United States of America: Indiana, 2009. p. 185.
} 
seus êxtases. Assim, embora a intencionada formulação polêmica de ambos os temas (natural e sobrenatural), esperava-se alguma exposição apologética, num tratado filosófico-teológico. A maioria dos concursantes preferia o enunciado do terceiro tema que abordava o tratamento científico. E com esse enfoque médicocientífico foi que chegou da Bélgica um dos trabalhos mais importantes do evento, enviado pelo discípulo de Charcot, o jesuíta Padre Guillermo Hahn, professor de Fisiologia do Colégio da Companhia de Jesus de Lovain.

O trabalho, escrito em francês, imediatamente captou a atenção do jurado examinador e foi apresentado abertamente ${ }^{387}$. Ligava-se ao tema número três do Concurso. Pe. Hahn propunha à banca uma reformulação para que ele fosse do âmbito da ciência e não um tratado apologético, filosófico-teológico, como estava no programa do Evento, dado ter uma formulação um tanto pesada, que dizia:

Quando os racionalistas concedem a Santa Teresa de Jesus uma grande facilidade e força de reflexão e um conhecimento claro, exato e profundo das funções e atos de sua alma, nos oferecem sob este mesmo ponto de vista, uma evidência conclusiva para demonstrar que a doutora estava perfeitamente disposta a distinguir entre o natural e o sobrenatural e que não sofre ilusão quando nos fala desta segunda ordem, com tanta segurança, como da primeira $^{388}$.

Neste molde seria, na verdade, um tratado filosófico-teológico. A reivindicação e a reformulação do professor faziam sentido e foram aceitas ${ }^{389}$.

$\mathrm{O}$ estudo do Pe. Hahn tinha como título: Os fenômenos histéricos e as revelações de Santa Teresa. Ao editá-lo, no ano seguinte à premiação, em Bruxelas, na página cinco, lia-se, em nota: Memória premiada no concurso de Salamanca, em 23 de outubro de 1882. Na edição bruxelense de 1883 destacou-se intencionalmente o título da obra: Os fenômenos histéricos, ficando como mero subtítulo a alusão à Santa Teresa. Na capa: Os fenômenos histéricos e as revelações de Santa Teresa, G. Hahn S.J. Professor de Psicologia do Colégio da Companhia de Jesus em Louvain. Memória coroada no concurso de Salamanca ${ }^{390}$. No desenvolvimento do argumento, o autor seguiu um caminho linear e fixou critérios metodológicos. Entre os argumentos propostos, Hahn propunha-se a defender o caráter e as revelações da santa contra os ataques dos incrédulos.

\footnotetext{
${ }^{387}$ Cf. ALVAREZ, T. Teresa a contraluz ... p. 15-16.

${ }^{388}$ Ibidem. p. 17.

${ }^{389}$ Ibidem. p. 17-18.

${ }^{390}$ Cf. Revista de questões científicas, 1883. Bruxelas, p. 183. In: ALVAREZ, T. Teresa $a$ contraluz... p. 17-18.
} 
Este era seu objetivo. A intenção apologética, secundária no contexto do trabalho e no conteúdo do livro, ficaria melhor refletida se o título fosse: Os fenômenos de histerismo, antes de as revelações, ou da experiência mística de Teresa. No trabalho de Pe. Hahn levantou-se três problemas ${ }^{391}$ :

1 Se é válida a explicação dos fatos místicos de Teresa ser considerados fenômenos histéricos. (O que fez o autor embarcar em uma minuciosa exposição das experiências e teorias recentemente formuladas por Charcot, acerca especialmente da grande histeria).

$2 \mathrm{Se}$, em sua vida e em suas qualidades pessoais, a santa ofereceu garantia de não estar sujeita às alucinações. (Com isso, estuda a biografia da santa, suas enfermidades, a crise referida por ela em Vida 5-6, suas respostas em situações conflitivas, em sua liderança e cartas, até sua morte).

3 Se as revelações da Santa, em seu conjunto, apresentavam notas marcantes que as distinguiam dos fenômenos de origem puramente natural, sim, ou não? A resposta é dupla: negativa para as manifestações diabólicas. Claramente positiva, enquanto visões e revelações de origem divina (onde Teresa julga ter somente a Deus).

Tendo se estabelecido a base da observação experimental e a correlação entre o aspecto físico e o aspecto moral, nos casos de histeria, o autor chega à conclusão de que a reformadora do Carmelo fez exceção à lei estabelecida e apresenta o caso da monja como uma situação excepcional à base dos fatos incontestáveis. Em outras palavras, para Hahn, Teresa seria psíquica, intelectual e moralmente normal e fisicamente enferma, o que o fazia afirmar, também, que não era possível chamar a Teresa de mística histérica ${ }^{392}$.

Hahn refere que a santa jamais confundiu fenômenos extraordinários com percepções sensíveis de ordem natural e que soube distinguir, perfeitamente, sua comunicação com as criaturas e o que era comunicação com a divindade. Para ele, a coerência das experiências que Teresa teve com o divino, inseriu-se nos acontecimentos da vida real e cotidiana e se encontra em nítido contraste com a incoerência notória das alucinações e à vida real das histéricas. Deste modo, a conclusão do estudo de Pe. Guillermo Hahn resume-se em três afirmações:

\footnotetext{
391 ALVAREZ, T. Teresa a contraluz... p. 19.

${ }^{392}$ Cf. ALVAREZ, T. Teresa a contraluz ... p. 20.
} 
1 No plano orgânico fisiológico, Teresa sofre uma enfermidade epileptiforme, com todos os sintomas da gran histeria.

2 Enquanto para o geral das enfermas histéricas as anomalias físicas provocam grandes distúrbios mentais e morais, Teresa é uma exceção. Nela não há sintoma de perturbação mental, ou moral.

3 Por este fato, não se pode qualificar Teresa como uma enferma histérica.

Desta forma, Padre Hahn concluiu seu estudo, transcrevendo o texto salamantino formulado ao tema do III Centenário Teresiano e que, segundo ele, seria: uma perfeita síntese de todo o exposto nas 183 páginas de seu trabalho ${ }^{393}$.

O mérito do autor belga consistia na confrontação teresiana (pessoa, biografia e o testemunho expresso de Teresa), com os últimos resultados da medicina recém-fornecidos pela escola de $\operatorname{Charcot}^{394}$. Seu estudo produziu forte impacto no jurado salamantino, começando pelo Prelado organizador. O jurado salamantino: duas pessoas da Academia Espanhola, dois Cânones de Salamanca, o Vice-Reitor e dois professores de Direito da Universidade da cidade, o Reitor do Colégio de São Carlos, o provincial dos dominicanos, o prior do convento dos franciscanos e o Reitor do Colégio de Nobres, outorgaram-lhe o melhor prêmio, e ainda acrescentaram-lhe uma medalha de ouro ${ }^{395}$.

Entre as cláusulas do programa havia uma que prescrevia: A junta organizadora do concurso terá direito à publicação e fica com a propriedade em outras edições ${ }^{396}$. Com isso, imediatamente foram publicados os dois primeiros números das Revistas de Questões Científicas (Bruxelas 1883). O livro à parte era considerado extrato da mesma revista. E, até o momento, tudo andava bem. Contudo, nem todos no meio católico, tiveram o entendimento, ou como diz Padre Tomás Alvarez: a lucidez, ou a ingenuidade do jurado salamantino ${ }^{397}$. Assim, apesar da seriedade científica e do rigor metodológico do Padre Hahn, na obra não

\footnotetext{
${ }^{393}$ Ibidem. p. 19-21.

${ }^{394}$ Charcot abandonou a definição antiga de histeria substituindo-a ao conceito mais moderno de neurose. Reduziu essa a uma origem traumática com ligação com o sistema genital e depois demonstrou a existência da histeria masculina traumática, muito discutida na época, em Viena e em Paris. Assim fez da histeria uma doença nervosa e funcional, de origem hereditária e orgânica. E para distinguí-la uma vez por todas da simulação, recorreu à hipnose: adormecendo as mulheres na Salpêtriérè, fabricava sintomas histéricos experimentalmente, fazendo-os desaparecer imediatamente, provando assim o caráter neurótico da doença. Cf. ROUDINESCO, E. Charcot, Jean Martin... p. 109.

${ }^{395}$ ALVAREZ, T. Teresa a contraluz... p. 24.

396 Idem.

${ }^{397}$ Ibidem. p. 25.
} 
faltaram sombras e ambiguidades. O texto, abaixo, dá uma visão geral dos principais nós do enredo que, posteriormente se converteram em polêmicas.

Segundo Tomás Alvarez, quanto a enfermidade estrutural de Teresa é preciso analisar três observações: primeiro, o fato de Pe. Hahn abordar praticamente só o episódio da sua crise de juventude, não reitera, nem tampouco comprova, a patologia ao longo de sua vida; segundo, ao enquadrar Teresa na histeria corporal (fisiológica), a obra a deixa imune de todo o histerismo no plano intelectual e moral; e, terceiro, ao se apresentar concretamente o problema das visões e revelações da santa, a obra a apresenta objetiva e sã de mente, quanto às revelações divinas, mas alucinada em relação às visões diabólicas e outras ${ }^{398}$.

Padre Tomás Alvarez refere que, por detrás da meticulosa análise do processo histérico estabelecido por Charcot, (assumido na obra do Padre Hahn), ao aplicá-lo na prática à Teresa, não deu para se visualizar em qual ponto, de fato, se irrompeu, ou se interrompeu o processo da enfermidade teresiana. Questiona se seria esta irrupção depois do primeiro período epileptóide definido por Charcot, ou depois do segundo período, o de Clowinismo, depois do terceiro período das atitudes passionais, ou seria no quarto período, de delírio? De igual forma, não se podia ver claro, em qual grau dos estágios ocorreu a dita exceção, descrita, em favor de Teresa ${ }^{399}$. Para melhor compreender os questionamentos de Tomás Alvarez, faz-se uma digressão a Charcot, referente à histeria. Sabe-se que Charcot, para realizar suas pesquisas, lançava mão de hipóteses e recursos científicos:

Para mostrar que a histeria não era uma doença do século, mas um mal estrutural, submetido a uma nosografia específica [descrição metódica da doença], Charcot mostrou que as suas marcas eram detectáveis nas obras de arte do passado[...]. Para ele, tratava-se de encontrar nas crises de possessão e nos êxtases, os sintomas de uma doença que ainda não recebera a sua definição científica.

Afunilando suas pesquisas conseguiu uma descrição inicial minuciosa

O estudo do quadro de Rubens, representando Santo Inácio curando os possuídos the forneceu, assim, a ocasião de descrever inúmeros detalhes, os períodos do grande ataque histérico: a "fase epileptóide", quando a doente se contraía em uma bola e dava uma volta completa em torno de si mesma, a "fase de clownismo" com seu movimento em arco de círculo, a "fase passional", com seus êxtases e, enfim o "período terminal", com suas crises de contraturas generalizadas. A isso, Charcot acrescentava uma variedade "demoníaca" da

${ }^{398}$ Idem.

${ }^{399}$ Ibidem. p. 28. 
histeria: aquela em que a Inquisição via os sinais da presença do diabo no útero das mulheres ${ }^{400}$.

Ao tomar-se como premissa a suposição de que a histeria era uma doença e não uma simulação, ou um emaranhado de sintomas, Charcot começou por distinguir as mulheres histéricas das epilépticas, em suas pesquisas. Deste modo:

Em 1870, uma reorganização na estrutura interna do La Salpetrière legou a Charcot toda a responsabilidade pelas pacientes não insanas classificadas como histéricas ou epilépticas. Essa ocorrência fortuita aumentou muitíssimo suas oportunidades de pesquisa e, a partir desse momento, ele se sentiu cada vez mais atraído para o estudo da histeria - "grande neurose",401.

Assim, a grande neurose, também chamada de a grande histeria, foi o primeiro nome dado por Charcot, ao assumir essa responsabilidade pelas pacientes no hospital de La Salpetrie, dado que, até o momento não havia, ainda, uma definição satisfatória do termo histeria e a suposta doença, ao longo dos séculos, associava-se a uma desnorteante variedade de sintomas ${ }^{402}$. Sendo assim,

Em 1853, o médico inglês Robert Carter observou que havia no conceito de histeria "uma inexatidão sem paralelos na fraseologia científica". Pouco depois, o especialista americano em doenças nervosas Silas Weir definiu histeria como "o limbo nosológico de todos os males femininos sem nome" e sugeriu que "tanto fazia chamá-la de misteria". Em 1878, um contemporâneo de Charcot, o alienista francês Lasèque, descartou até a possibilidade de definí-la: "A definição da histeria jamais foi dada e jamais será". Os sintomas não são suficientemente constantes nem semelhantes na forma, nem iguais na duração, ou intensidade, para que uma categoria, mesmo descritiva, pudesse abrangê-los todos" $" 403$.

Charcot abraça a causa e dá andamento às pesquisas. Percebe que algumas pacientes apresentavam poucas manifestações do grande ataque, como breves contrações da mão, dos braços, ou das pernas. Demonina a estes ataques de menores, ou formes frustes (formas da doença muito atenuadas na intensidade, ou nos sintomas), ou ainda de hysteria minor, em oposição à hysteria major ${ }^{404}$.

Sua pesquisa começa por distinguir diferentes sintomas, classificar os diversos tipos de histeria e nomear distintos quadros e graus, o que antes se considerava uma miscelânea. A pesquisa era inovadora, necessária e relevante para a época, porque, não obstante, o conceito e a prática de cuidados da histeria

\footnotetext{
${ }^{400}$ ROUDINESCO, E. Charcot, Jean Martin... p. 109.

${ }^{401}$ WEBSTER, R. Por que Freud errou: pecado, ciência e psicanálise. Tradução de Alda Porto. Rio de Janeiro: Record, 1999. p. 64.

${ }^{402}$ Idem.

${ }^{403}$ Ibidem. p. 65.

${ }^{404}$ Cf. WEBSTER, R. Por que Freud errou ... p. 67.
} 
já viessem desde os tempos de Platão (onde os médicos, nomeavam de histeria a um determinado conjunto de sensações descrito pelas pacientes), tudo era ainda muito indefinido e indeterminado. Apenas uma constante se pontuava em toda essa mistura de sintomas: a sugestão. Esta vinha nos muitos relatos das pacientes, que referiam ser o útero a origem destes males e daí a subir pelo corpo todo, até a cabeça. Assim essa teoria complexa derivava da experiência subjetiva das vítimas dos ataques histéricos e a mulher que os sofria, tinha a sensação de estreitamento do tórax e, ao chegar à garganta, causava sufocação como por uma bola - o globus hystericus. Às vezes, a mulher sofria apenas um lapso de consciência. Mas em outras, desabava em convulsões ${ }^{405}$. Com o aprofundamento da pesquisa de Charcot defendia-se que, além das formas convulsivas, havia muitas espécies nãoconvulsivas de histeria que não resultavam em ataques. Deste modo,
Algumas pacientes supostamente manifestavam a doença com paralisias, ou contraturas histéricas, em que os músculos permaneciam o tempo todo retesados. Outras revelavam que sofriam de histeria com várias perdas, ou distorções da função neurológica para as quais não existia à época qualquer explicação. Outras ainda sofriam de distúrbios de movimento hipoteticamente histéricos, como "coréia histérica, em que apresentavam movimentos rítmicos estereotipados, ou "abasia astasia", quando, embora pudessem executar todos os movimentos normais ao serem examinadas na cama, não podiam ficar de pé, nem andar. E outras, ainda, eram acometidas de sonambulismo, automatismos ambulatórios, ou fugas amnésicas em que esqueciam a própria identidade ${ }^{406}$.

Tendo melhor compreendido o entendimento da histeria em seus primórdios faz sentido resgatar os questionamentos de Padre Tomás Alvarez. Para o teresianista, o Padre Hahn também ficava flutuante, ou na superfície em relação ao chamado Problema de São José, que logo agitou os espíritos discrepantes a respeito do Padre fisiologista. Pergunta-se, afinal: o santo chegou a intervir, ou não, na conclusão da terrível crise juvenil de Teresa, descrita em Vida $6^{407}$ ?

Volta-se, em seguida a isso. Dois anos depois da edição, o livro do Pe. Hahn foi delatado à Congregação do Índice e o Cardeal, Prefeito da mesma, pediu explicações ao Reitor do Seminário Salamantino, Padre Luis Martín, de como pôde o Padre Hahn ter sido o premiado em Salamanca ${ }^{408}$. Em 16 de janeiro

\footnotetext{
405 Ibidem. p. 65.

406 Ibidem. p. 66.

407 Em V 6, Teresa atribui a recuperação de sua saúde à intercessão do glorioso São José.

${ }^{408}$ Em 1571, Pio V estabeleceu uma congregação especial do Índice (antigo Index, onde se selecionavam e queimavam as obras consideradas hereges), cujas atribuições foram transferidas para o Santo Ofício (agora intitulado de Congregação para a Doutrina da Fé; o próprio Indice foi
} 
(1886), o Cardeal Barlonini escreve ao vigário Geral S.J. que os Padres Smedt e Hahn deviam ser gravemente admoestados ${ }^{409}$. Além disso, o último devia também ser vigiado em sua classe de Fisiologia, em Louvain. O Padre vigário escreveu ao Cardeal Martinelli, Prefeito do Indice, que urgia a decisão de que Hahn se calasse em obediência e lhe fosse abolida a classe de Fisiologia que lecionava ${ }^{410}$.

O surpreendente no caso foi o fato de Pe. Hahn, com toda lealdade, ter submetido seu livro a um rigoroso exame antes de enviá-lo à Salamanca. E, depois da premiação, antes de dá-lo à imprensa, voltou a submetê-lo a novos censores, assessores excepcionais. Em estrita justiça para com ele, Padre Tomás Alvarez recorda esses dois momentos. Assim, havia revisado sua redação o provincial jesuíta da Bélgica, J. Van Reeth, o qual, por sua vez, também a submeteu ao exame de três professores de prestígio e a enviou como dossiê à Fiesole (Itália), submetendo-a, ainda, à revisão do Padre Geral da Companhia: Pe.

A. M. Anderledy. Este respondeu:

Quero informar a Vossa paternidade sobre o que se fez a propósito da Memória sobre as visões e as revelações de Santa Teresa, escrito pelo Pe. Guillermo Hahn e destinado ao concurso aberto na Espanha por ocasião do III Centenário da Santa. Vossa Paternidade verá se em tudo se procedeu segundo as regras do Instituto e se existe algo a mais a fazer ${ }^{411}$.

Pe. Van frisa que Pe. Hahn tinha permissão para participar no concurso sobre o tema das visões, ou revelações de Santa Teresa e que seu objetivo era provar que a histeria orgânica existiu na Santa, contudo sem a histeria intelectual. Por conseguinte, suas visões e revelações são sobrenaturais e sua conclusão havia sido que Santa Teresa não podia ser denominada de histérica no significado próprio do vocábulo, assegurando-lhe que a demonstração de Hahn era peremptória e o trabalho de grande importância. Em suma, foi submetido, então, à aprovação de dois teólogos e mais um bolandista: Pe. Cam, Pe. Van de Velde, professor de moral e ao Pe. Carlos de Smedt. Inclusive, os três censores haviam sido favoráveis à publicação do livro. De forma que nada, até o momento havia

abolido em 1966. LINDBERG, C. As Reformas na Europa. Tradução de Luiz Henrique Dreher e Luis Marcos Sander. São Leopoldo: Sinodal, 2001. p. 406.

${ }^{409}$ Padre De Smedt, grande amigo de Padre Hahn ofereceu-lhe, em todo tempo, apoio e incentivo aos seus estudos científicos em relação à Teresa, contribuindo com a divulgação de sua pesquisa. WISEMAN, N. P. The Revelations of St. Theresa. In: The Dublin Reviev. Califórnia: Burns and Oates, 1884. p. 193.

${ }^{410}$ Cf. ALVAREZ, T. Teresa a contraluz... p. 25.

${ }^{411}$ Ibidem. p. 31. 
freado a publicação do livro, que veio através de duas vias: como artigo de revista e como obra autônoma, com todos os direitos e cidadania.

Após sua edição, uns se colocavam a favor e outros contra Pe. Hahn. Desta forma, ecos da importante polêmica chegaram fortes à Salamanca e à Roma, em fins de 1884. Aí, Roma intervém. Não alivia os passos, mas os acelera. O prefeito da Congregação para os Ritos, Cardeal Bartolini, solicita previamente o parecer do Prepósito Geral dos Carmelitas, Padre Jerônimo Gotti, genovês, homem culto e dinâmico, que em 16 de março de 1885 responde ao Cardeal, apresentando, por sua vez, suas considerações a respeito do livro do Pe. Hahn. Segundo ele, observam-se no livro do Padre Hahn seis aspectos vulneráveis:

1 juízos e expressões desrespeitosos em relação a autoridade Pontifícia e à Congregação dos Ritos;

2 afirmações não verdadeiras e injuriosas a respeito de Santa Teresa e nocivas para a piedade dos fiéis;

3 arbitrárias e perniciosas concessões aos racionalistas;

4 Afirmações tendenciosas que minam o valor e o crédito dos escritos de Santa Teresa e, consequentemente, sua eficácia;

5 Afirmações imprudentes e danosas em torno às aparições demoníacas e das visões que atormentavam a santa;

6 Afirmações imprudentes e ofensivas "piarum aurium", em torno à cura de Santa Teresa, por intercessão de São José ${ }^{412}$.

Dois meses depois, em maio de 1885, Pe. Hahn já sabe a provável opção condenatória de seu livro pela congregação dos Ritos. Apressa-se, em notificar ao Geral, Pe. Anderledy, suplicando-lhe que faça o possível para evitar a iminente decisão romana que, contudo, foi publicada a primeiro de dezembro de 1885 , seguida da inclusão no livro do Indice de obras proibidas, com decreto de onze de janeiro do ano seguinte, assinado, entre outros, pelo Padre dominicano Pio Saccheri Secretário, a quem Padre Hahn havia obsequiado e inclusive dedicado a sua obra. No texto mesmo deste posterior decreto, constava que o autor contemplado submetia à reprovação o opúsculo. Aparente ponto final, que fica bem longe, de fato, de sê-lo. Assim, para o Pe. Hahn seguiram-se dois anos de

${ }^{412}$ ALVAREZ, T. Teresa a contraluz... p. 35. 
intensos sofrimentos, angústias de consciência, sincero desejo de submissão e defesa, sem renunciar à devida lealdade científica ${ }^{413}$.

Após isso, em:

1884 - Na Bélgica e na França, polêmica: o bolandista Carlos de Smedt escreve a favor e, na França, Morel e Touroude contra a obra do Pe. Hahn. Há repercussões também na Espanha.

16.03.1885 - Em Roma, o Geral dos Carmelitas, Pe. Ristretto, coloca-se contra.

06.05.1885 - O provincial dos jesuítas belga, Pe. Van Reeth, escreve alarmado ao Pe. Geral, S.J., residente em Fiésole, ante a incerteza da condenação do livro de seu súdito, no intuito de contrabalançar o impacto da publicação do decreto.

06.05.1885 - Pe. Hahn escreve submisso ao Pe. Geral Anderledy, pede que seu livro não seja julgado pela Congregação do Índice. Refere confiar que as aprovações outorgadas pelo jurado salamantino sejam suficientes para avaliá-lo ante ao Tribunal Romano. Escreve ao Cardeal Martinelli prefeito da Congregação.

01.12.1885- Em Roma, a obra é condenada pela congregação dos Ritos.

11.12.1885- Pe. Hahn escreve novamente ao Geral, antes de receber a resposta do Cardeal Martinelli, que notificava a inclusão próxima de sua obra no Index:

Estou desolado [...] por tudo o que fiz involuntariamente à nossa Companhia. Meu ato de submissão deterá absolutamente a publicação do decreto e a inclusão no Index? [...] Se minha memória se insere no Index, os números da revista na qual se publicou ficariam igualmente sob a condenação e a sociedade não poderia adiante vender coleções completas da dita revista.[...] Compreendo o delicado que seja para a Companhia ter em seu escolasticado um professor que foi objeto de condenação por parte da Santa Sé. Por isto, envio ao Padre Vigário Provincial a súplica de deixar-me livre de meu curso e destinar-me a outras atividades ${ }^{414}$.

Perseguido e esgotado, longe de sua cátedra, Pe. Hahn adota sozinho a decisão final: retirar-se da Companhia. Triste desenlace do episódio. Em uma longa carta de dois de Julho de 1887, ao Pe. Geral, desabafa: Quero tomar sobre mim toda a responsabilidade. E conclui: Tenho duvidado muito e sofrido muito antes de chegar a este passo decisivo. Morreu em Namur, em 10 de dezembro de 1903. Contudo, em 1906, depois de sua morte, publicou-se a versão alemã de sua

\footnotetext{
${ }^{413}$ Idem. p. 37-38

${ }^{414}$ ALVAREZ, T. Teresa a contraluz ... p. 38.
} 
obra, de Paul Prina e a edição se intitulou: Os problemas de histeria $e$ as revelações de Santa Teresa - Leipzig $1906^{415}$.

\subsection{2}

\section{Teresa à contraluz na Ciência e na Psicologia nascente}

Foram três os fatores determinantes da polêmica em torno da santa: o endeusamento popular de seu III Centenário 1880-1882; o livro do Pe. Hahn, em 1883, empenhado em fixar fronteiras entre a enfermidade e o lado místico de Teresa e as condenações de Roma: 1885-1886. Esses fatos marcaram para Teresa o passo da luz à contraluz, desde a hagiografia e artes, até as ciências médicas.

A repercussão da obra de Hahn fez o caso teresiano deixar de ser um episódio biográfico de menor escala e passar a ser um problema assumido como alternativa pelas ciências médicas, psicologia, teologia e metafísica, com duplo conteúdo intercambiável as enfermidades de Teresa e os seus fenômenos místicos.

Assim, pode-se perguntar se o que viveu e escreveu Teresa cai do lado da patologia, ou do lado da mística e da transcendência? Teresa foi uma mística, ou uma paciente sem clínica adequada? E, dada a historiar-se a si mesma, seria capaz de discernir os sintomas neurológicos de suas vivências místicas? Seria realmente capaz compreender e distinguir o natural do sobrenatural? É Teresa, um testemunho autêntico, fantasioso, ou falso do mais além religioso e/ou científico?

Assim, enquanto o livro do Padre Hahn viajava de Salamanca à Roma, ao redor havia um debate sério, de escala inferior, porém mais livre, também uma autêntica proliferação literária, com representantes exímios na Bélgica, na França e na Espanha, na Alemanha e no Centro da Europa. Dessas fontes bibliográficas, um tanto remexidas, citam-se representantes nos três episódios representativos.

$1^{\circ}$ Um eminente difusor da tese pró-histeria, na Bélgica;

$2^{\circ}$ Dois opositores frontais na França;

$3^{\circ} \mathrm{Um}$ teólogo cientista na Espanha.

A obra do Pe. Hahn viu a luz em uma revista cientista de alto nível. E Pe. Carlos De Smedt (diretor e renovador dos padres bolandistas) ${ }^{416}$ apressou-se em

\footnotetext{
415 Ibidem. p. 40.

${ }^{416}$ Carlos De Smedt (1833-1911) é um dos mais célebres bolandistas do Século XIX. Em 1870 havia publicado seus Estudos religiosos e nesse mesmo ano nomeado bolandista. Em 1976 sucede a V De Buck na direção do grupo. Em 1882 funda a revista Analecta Bolandiana. Fundará mais
} 
levá-la a outra revista ${ }^{417}$. Quanto ao eminente difusor da tese pró-histeria, o Padre Hahn teve o apoio do padre Carlos De Smedt, bolandista. Com isto, posições a favor da teoria do histerismo teresiano foram tomadas em duas revistas tops: $A$ revista das Questões Científicas de Louvain, na qual tinha se publicou o livro do Pe. Hahn e a Revista das Questões Históricas de Paris (belga e francesa), na qual se publicou o primeiro artigo de Padre Smedt, com o título: as Revelações de Santa Teresa ${ }^{418}$. Em seu artigo, o Pe. De Smedt fez uma apresentação que servia como introdução e como porta-voz da teoria médica do Pe. Hahn. Distinguia nela dois aspectos no problema da santa: o teológico e o científico. Como o aspecto teológico supunha-se já estabelecido pelo jurado dos teólogos de Salamanca, propôs-se a se ocupar somente do aspecto científico, o que, de fato, interessava aos não crentes, com os quais o livro de Pe. Hahn dialogava ${ }^{419}$.

Pela sua leitura, Pe. Smedt afirmava ser Teresa um caso de histeria orgânica em seu mais alto grau. Ou seja: sofreu a grande histeria, ou a histeria epiléptica, sem que a mesma chegasse a afetá-la no plano intelectual, ou moral. Contudo, uma parcela de suas revelações poderia ser explicada como alucinação pessoal. Sua conclusão sobre a tese do Pe. Hahn ${ }^{420}$ :

nos parece perfeitamente justa. Não duvidamos em qualificar de luminosa esta demonstração e em declarar que nos convence plenamente. Nos congratulamos, particularmente, de ver o tema tão delicado das visões e revelações de Santa Teresa tratado a fundo pela primeira $\mathrm{vez}^{421}$.

Em seguida a essa tomada de posições, De Smedt lamenta por não ter sido submetido à análise científica também os êxtases da Santa. Diz que, em sua qualidade de bolandista, sente-se obrigado a protestar contra um de seus predecessores, J. Vandermoere, encarregado poucas décadas antes, do volume da Acta Sanctorum reservado à Santa Teresa, o qual negava que os êxtases de Teresa fossem ataques de histeria ${ }^{422}$.

tarde outros órgãos bibliográficos. Já ao final de sua vida publicará os dois significativos volumes "Nossa via natural" (Bruxelas 1910-1911). Cf. ALVAREZ, T. Teresa a contraluz... p. 42.

${ }^{417}$ MOURRET, F. A history of the Catholic Church. vol. 5. Translation por Rev Newton Thompson. [s.1.] Herder, 1946-1957. p. 599.

${ }^{418}$ A um passo da fronteira da Bélgica e da França, onde posteriormente há outros escritos. Cf. ALVAREZ, T. Teresa a contraluz... p. 43.

${ }^{419}$ Idem.

${ }^{420}$ Idem.

${ }^{421}$ Ibidem. pp. 43-44.

${ }^{422}$ Por Acta Sanctorum, compreende-se um termo latino que significa: feitos e histórias dos santos, hagiografia, coleção de relatos da vida dos santos da Igreja Católica Romana e da Igreja Ortodoxa 
Assim, tudo se complicava um pouco mais. De Smedt desinteressou-se do aspecto teológico sobrenatural no caso teresiano e ocupou-se somente do problema científico natural. Em seguida à impressão, imediatamente chegaramlhe as cartas de opositores, por todos os lados, solicitando-o a retroceder os passos e a afrontar o problema primeiro. Para respondê-las, publica apressadamente um segundo artigo, com mais sete páginas, na mesma revista, pontuando ao menos uma parte do problema teológico, antes ignorado. Nela surprendeu a todos com sua drástica rejeição ao bolandista Vandermoere, que nesse momento gozava de alto prestígio entre os teresianistas da Bélgica, da França e da Espanha. Efetivamente José Vandermoere tinha incluído em seu imenso volume das Actas Sanctae Teresiae um pequeno tratado sobre seus êxtases. Não se limitou à hagiografia e à teologia, mas apresentou a hipótese materialista que já estava em voga nos estudos, nos Dicionários e nas Enciclopédias laicas da França e da Bélgica, chegando à conclusão negativa a respeito dessas explicações. Intitulava, assim, o posterior capítulo da dita sessão de sua obra: Finalmente nem histeria, nem catalepsia podem ser incritos os êxtases de Santa Teresa ${ }^{423}$.

Pe. De Smedt analisa, mas conscientemente as rejeita, afirmando que o único motivo do rechaço destas páginas era o fato de Vandermoere, como a ciência de seu tempo, não entender de histeria. E conclui seu artigo:

O bolandista que assina este artigo (eu Pe. Smedt), por nada do mundo titubeia em dizer que me afasto claramente do parecer expresso pelo Pe. Vandermoere já há uns 40 anos. Porém, em justiça precisa se acrescentar que o Pe. Vandermoere é perfeitamente desculpável por haver defendido então essa opinião[...]. Todo o erro do Pe. Vandermoere consistiu em não haver se adiantado à ciência médica de seu tempo. É um erro de fácil perdão. Queira Deus que nunca censuremos a nós mesmos com outros erros similares ${ }^{424}$.

O mais surpreendente é que em seu artigo falando sobre a histeria e catalepsia de Teresa De Smedt não reflete o pensamento alheio, de forma

Oriental. Cf. SHÜLLER, A. Dicionário Enciclopédico de Teologia. Canoas: Ed. ULBRA, 2002. p. 20.

${ }^{423}$ Cf. VANDERMOERE, J. Acta Sanctorum Teresiae a Jesu. Carmeitarum strictioris observantiae parentis. Commentario et Observationibus illustrata. Bruxellis, 1845. n. 96. p. 2.

[Documento on line, disponível em http://books.google.com.br/books? $\mathrm{id}=\mathrm{uBYJIkQzwc} 8 \mathrm{C} \& \mathrm{pg}=\mathrm{PA} 2 \& \mathrm{dq}=\mathrm{VANDERMOERE},+\mathrm{J} .+\mathrm{Acta}+$ Sanctorum+Teresiae $+\mathrm{a}+\mathrm{Jesu} \& \mathrm{hl}$ $=$ tBR $\& s a=X \&$ ei $=$ tXTIUauAHIrA0gHB $x I H 4 A g \& v e d=0$ CDMQ6AEwAA\# $=$ onepage $\& \mathrm{q}=\mathrm{VAND}$ ERMOERE\%2C\%20J.\%20Acta\%20Sanctorum\%20Teresiae\%20a\%20Jesu\&f=false. Acessado em 19.03.2013, às $15 \mathrm{~h}$.

${ }^{424}$ ALVAREZ, T. Teresa a contraluz... p. 46. 
pessoal $^{425}$. Dá seu parecer como diretor dos bolandistas. Assim, se pouco antes havia previsto um estudo aprofundado dos êxtases da santa, agora, sem esperar esse estudo se pronuncia e protesta, porque o bolandista o afrontou, negando que os êxtases de Teresa se reduziam a sintomas de histeria. E Tomás Alvarez, questiona: "com isso De Smedt queria dizer que os sintomas de Teresa eram histeria, e que a 'nobre espanhola' viveu e escreveu envolta em uma nuvem de confusões?"426.

Os opositores imediatos não perdoaram ao Pe. De Smedt o desnecessário repúdio ao seu colega bolandista. Tampouco, seu precipitado documento a respeito do histerismo teresiano. Contudo, quando chegou de Roma a condenação do livro premiado, De Smedt, volta atráz e submete-se à sentença romana.

Quanto aos opositores, mais que na Pátria de Teresa, foi em clima francófono que o caso teresiano inflamou os ânimos e as dores. Aí foram numerosas as manifestações, iniciando por dois franceses, que intervêm antes da condenação romana em diálogo cruzado com os dois anteriores.

O primeiro opositor surge em Lyon (1884). É o abade Jules Morel que, ao propor-se a defender a santa, em nome da teologia, esmiuça-a frente à ciência. Publica uma pequena lista de brochuras, entre 16 e 20 páginas cada uma. Primeiro na revista lionesa: A controvérsia e a contemporaneidade (dez./1884), a qual responde o Pe. Hahn (jan./1885). Em seguida mais duas brochuras, intintuladas: Santa Teresa. O primeiro no diálogo com o Padre Hahn e o terceiro em polêmica com o Padre De Smedt, que publicou seu artigo, nesse mesmo ano, em Paris.

Não acertou centrar o problema de fundo: a experiência mística de Teresa. Desviou a atenção para o episódio: a intervenção de São José na cura da grande crise juvenil sofrida pela Santa ${ }^{427}$. Aqui, volta-se ao que acima ficou em aberto e recorda-se o problema. Em sua autobiografia conta Teresa em V 6, que ante a inutilidade das curas médicas recorreu à proteção de São José e que este a curou.

Fiquei, depois desses quatro dias de paroxismo, num estado tal que só o Senhor pode saber os insuportáveis tormentos que sentia em mim. [...]como se estivesse morta, sem ajuda; creio que só movia um dedo da mão direita[...]. Vendo-me

\footnotetext{
${ }^{425}$ Histeria e catalepsia eram as duas explicações naturalistas desde então em voga (1845). Em comparação com os sintomas presentes "na histeria comum, pertencentes ao mesmo universo psicopatológico a despersonalização e a representação de si nos casos de loucura histérica são muito mais intensos". ALONSO, S. L.; FUKS, M. P. Histeria: clínica psicanalítica. São Paulo: Casa do Psicólogo, 2004. p. 196.

${ }^{426}$ ALVAREZ, T. Teresa a contraluz... p. 46.

${ }^{427}$ Ibidem. p. 47.
} 
tão tolhida com tão pouca idade, e por não me valerem os médicos da terra, resolvi recorrer aos do céu para que me curassem[...]. Assim tomei por advogado e senhor o glorioso São José, encomendando-me muito a ele. Vi com clareza que esse pai e senhor meu me salvou, fazendo mais do que eu podia pedir $[\ldots]^{428}$.

Pe. Hahn havia limitado-se a notar que, enquanto milagre, não seria facilmente aprovado pela romana congregação dos ritos. Mas a afirmação de seu texto situava Teresa no tronco de sua teoria de fundo: traçar uma linha fronteiriça entre o sobrenatural e o patológico de Teresa. Aí, precisamente, encontrava-se com a oposição teológica e implacável de Morel, quem certamente advertiu De Smedt que bastava esse quadrante de alucinações teresianas para questionar não só o equilíbrio psicológico de Teresa, mas também seu espaço místico.

Assim, o teólogo opositor persiste no tema josefino. Tinha a sensação de que se viesse a se negar o sobrenaturalismo do episódio de Vida 6, tirava-se ao menos ao culto eclesial e popular à São José. E, nesta última instância, a exposição termina num baixo nível, onde Morel desqualifica o adversário e o inclui no número dos escritores excêntricos: Vamos guardá-lo no pequeno grupo dos jesuítas excêntricos, que o conhecem muito bem, como a muito bom religioso, e fizeram as suas opiniões conhecidas pelo seu paradoxismo. ${ }^{429}$.

O segundo grande opositor, o abade Touroude de Paris, interferiu no diálogo entre Morel, Hahn e Smedt, com duas cartas abertas dirigidas ao Pe. Hahn e em parte respondidas por ele. As duas foram publicadas em Paris, em 1885, com o título de Cartas endereçadas ao Padre Hahn. O Pe. Hahn responde à primeira, não a segunda, que veio à luz na antevéspera aos decretos romanos. Na primeira carta, Touroude se propôs analisar e derrubar afirmação por afirmação da hipótese do histerismo teresiano, baseando-se na análise científica da enfermidade e na descrição dos fenômenos de histerismo, desde a análise de seu estudo, assim:

a) Rotundamente não à hipótese do histerismo fisiológico de Teresa: não existem nela as típicas manifestações das graves crises. Na questionada enfermidade juvenil da Santa não se dá nenhum dos quatro sintomas indicadores. Nem a aura pródroma, anunciadora do ataque; nem a bola histérica ascendente desde o estômago e sufocante; nem o cravo histérico de dor situado no crânio ou

\footnotetext{
${ }^{428} \mathrm{~V} 6,1 ; 6,6$.

${ }^{429}$ Cf. ALVAREZ, T. Teresa a contraluz ... p. 49.
} 
na zona histerógena, do mesmo, segundo Charcot; nem as típicas convulsões que posicionam o corpo no arco circular indiferente. Nenhum desses quatro sintomas aparece na crise juvenil de Teresa, nem jamais ao longo de sua vida. Documenta.

b) Tampouco nela há algum indício do processo evolutivo subsequente à grave crise de histeria. Ou seja, nenhum dos quatro períodos estabelecidos por Charcot e assumidos por Hahn e pela escola charcotina: nem o período epileptóide, nem o subsequente estado de clowvinismo, nem a dos gestos passionais, ou imorais, nem finalmente o período cíclico de delírio.

c) De acordo no que diz, que psicologicamente, a mente de Teresa não sofre perturbações que quebrem seu equilíbrio, porém:

d) Total rechaço em relação à tese da excepcionalidade desta situação. Assim, para Touroude, em Teresa, não existem sintomas psíquicos, porque não houve os fisiológicos. Finalmente, ante a precisão dos dados analíticos alegados ao nível científico nos casos da grande histeria, diz que: jamais se pode alegar similares atos flagrantes na patologia de Teresa, senão unicamente dados que atestam as constantes de sua normalidade psíquica, ética, operativa, relacional e social. Por último, de um lado afirma absoluta capacidade da santa discernir entre o natural, sobrenatural e autenticar suas revelações, por outro retem-na alucinada nos relatos de suas visões diabólicas angélicas, de santos, de São José ${ }^{430}$.

À primeira carta de Touroude respondeu, de sua parte, o criticado Pe. Hahn com outra carta que difundiu na imprensa, autografada. Em seguida, publica uma segunda carta aberta, outras 40 páginas. Somam-se à polêmica mais dezenas de periódicos favoráveis a um, ou a outro oponente: alemães, italianos, húngaros e inclusive carmelitas e prelados franceses. Com isto, o diálogo começa a se enrijecer e Touroude o transpassa ao plano pessoal.

Desta forma, regressa nada menos que ao ponto de partida, ao Concurso Salamantino do ano de 1882 e ao jurado que outorgou o prêmio ao Pe. Hahn e começa a questionar se era, ou não, verdade que o dito jurado havia outorgado-lhe o prêmio? E, em caso afirmativo, se ainda persistiam nessa opinião os membros dos jurados? Em síntese, o Pe. De Smedt em sua elogiosa resenha ao livro premiado, havia escrito que o estudo do Pe. Hahn resultou tão excelente ao jurado salamantino que este não só lhe havia outorgado o primeiro prêmio do Concurso,

${ }^{430}$ Cf. ALVAREZ, T. Teresa a contraluz ... p. 49. 
mas também decidido aumentá-lo com uma medalha de ouro. Agora o Abade Touroude adota funções de detetive e leva a cabo uma série de pesquisas não só entre os teólogos de Salamanca, mas também aos membros do júri e escreve diretamente ao primeiro organizador do Concurso, Monsenhor Martinez Izquierdo, em vida. Assim, chegam-lhe as seguintes e desconcertantes conclusões:

- Que é errônea a afimação divulgada pelo Pe. De Smedt em relação ao livro em questão, pois não se lhe outorgou no Concurso salamantino o prêmio correspondente ao tema das revelações (número 3).

- Que o jurado do Concurso, em vista de que o livro de Hahn não enfrentou diretamente o tema proposto no dito número 3 do programa e o deslocou ao tema do número 5, que não tratava das revelações, mas dos êxtases de Santa Teresa.

- Que uma vez agregado ao grupo dos competidores deste número 5, o correspondente primeiro prêmio se concedeu ao estudo do catedrático espanhol Dr. Perales, da Universidade de Granada. Não ao trabalho do Padre Hahn.

- E, que se optou por assinar a este último o prêmio correspondente ao número 13 do programa ${ }^{431}$.

Resultado: o então premiado no Concurso salamantino não poderia ter sido um professor belga, mas um cientista espanhol. E, não se tratava de premiar ao tema das revelações de Teresa, mas a seus êxtases e arroubamentos. Ou seja, sua vida mística. Assim, o famoso Concurso de Salamanca, que havia tido a audácia de apresentar formalmente o caso teresiano, à teologia e às ciências, conseguiu convocar ao menos a dois homens ilustres: ao cientista belga, Pe. Hahn e a um cientista espanhol, o doutor Arturo Perales Gutierrez ${ }^{432}$.

Perales era professor de medicina na Universidade de Granada e doutor em teologia. Concorreu ao Concurso de 1882, com um volumoso texto para o quinto assunto do programa. São sobrenaturais, ou não, os êxtases e arroubamentos da Santa? Ao trabalho do professor se lhe outorgou o prêmio do quinto tema do Concurso. A seu respeito e em relação à Teresa, lia-se:

Mas todos estes ares que se levantaram contra a Santa espanhola, nenhum os resumiu melhor que o médico espanhol Arturo Perales, em uma obra muito sensata e conscienciosa, bem escrita, que longe de ser condenada foi muito bem

431 Cf. ALVAREZ, T. Teresa a contraluz... p. 53-54.
432 Idem. p. 55. 
recebida, até pelo episcopado, e ganhou o certame celebrado em Salamanca com o motivo do quarto centenário. ${ }^{433}$

Também Dr. Perales dará à imprensa seu própio estudo. Contudo, sem pressa. Contará a seu colega: "bons louros ganhou o Livro, com o fracasso de Salamanca; porém boas novas teve depois do atraso de sua publicação até agora. Por duas vezes o manuscrito foi perdido, e por duas vezes, refeito através dos rascunhos, notas e apontamentos do autor que serviram para reescrevê-lo",434.

Seu trabalho veio à luz em Madrid, em 1894, com o título de $O$ sobrenaturalismo de Teresa e a filosofia médica. E o súbtítulo: Os êxtases, raptos e enfermidades da Santa ante a ciência médica. Duplo enfoque e duplo tema: por um lado o enfoque filosófico-teológico e, por outro, a confrontação médica. E os dois temas: os fenomenos místicos e as enfermidades da santa.

Até o momento de Perales publicar seu livro, já era de domínio público o dramático desenlace da obra de seu oponente, Padre Hahn. Perales está bem informado dos dois fatos: da opção pró-histeria de seus colegas mais famosos, os médicos franceses e belgas e da condenação lançada por Roma. Tem uma postura de cientista católico e expressa-se: "Existe um magnífico livro que dá meridiana luz sobre esta matéria El supernaturalismo de Santa Teresa[...]”435.

Perales opta pelo diagnóstico histero-epiléptico nas enfermidades fisiológicas da santa e, pelo sobrenaturalismo de seus fenômenos místicos. Antes de publicar sua obra, pede ao arcebisbo de Madrid: Dom José Maria de Cos, sucessor do famoso Dom Narciso Martinez Izquierdo, para lê-lo previamente e conceder-lhe uma declaração de ortodoxia que publica na primeira página de seu livro, para garantir-lhe uma boa viagem pelo maremagnum teresiano. O autor está bem informado no teresianismo, na teologia e na medicina. As indispensáveis premissas teológicas, ou místicas, dedica à primeira parte de seu estudo "o que é o sobrenatural" (cap 1); “ o que são os êxtases de Santa Teresa” (cap. 5); "trata dos arroubamentos da santa” (cap.6) "trata das locuções e visões místicas (cap. 7).

${ }^{433}$ RUANO, A. La psicologia de Santa Teresa: posturas, feminismo, elegância. La psicología de Santa Teresa. Posturas. Feminismo. [s.l.]: Estúdios del Colégio filosófico "La Santa", 1950. p. 93.

${ }^{434}$ Prólogo da obra (p. 15), assinada pelo Dr. Fernando Segundo Brieva Savatierra, catedrático da Faculdade de Filosofia e Letras da Faculdade de Granada. Cf. ALVAREZ, T. Teresa a contraluz... p. 55 .

${ }^{435}$ TELLEZ, E. V. Crítica filosófica: ó Estudio bibliográfico y crítico de las obras de filosofia, escritas traducidas ó publicadas en México desde ele siglo XVI hasta nuestros días. México, 1904. p. 442 . 
Está também melhor informado, no setor médico-científico, muito à corrente da abundante literatura da Escola de Charcot e outras congêneres. Em seu trabalho se remete aos estudos de Briquet, Charcot, Monneret, Landonzy, Georget, Regnard, Bouneville, Pfendler, etc. Sobre essas bases enfrenta o duplo argumento: $a$ enfermidade e os fenômenos místicos de Teresa ${ }^{436}$. Perales cede às correntes neurológicas de seu tempo e, ante as enfermidades de Teresa, é categórico: segundo ele, esta padeceu a grande histeria, com os sintomas e as manifestações fixadas por Charcot. Sofreu as etapas epileptiforme e clownica, mas não as etapas das atitudes passionais e de delírio. Com abundantes sintomas, segundo ele, proporcionados pelos textos autobiográficos da Santa, sustenta a unidade e a continuidade do sistema nervoso com a parte mais nobre do ser humano, quanto à espiritual afirma que a zona intelectual e moral de teresa, apesar de seu caráter histérico, está totalmente imune de perturbações psíquicas. Motivo pelo qual todos os seus fenômenos místicos são autênticos, ou seja, sobrenaturais. E a santa está plenamente capacitada para discernir entre o natural e o sobrenatural. Sintetiza, suas conclusões: "Santa Teresa de Jesus, histérica, já em sua adolescência sofreu em sua juventude um ataque letárgico, com morte aparente na forma do grande histerismo de Charcot, ou da histero-epilepsia de outros autores e continuou sofrendo quase até seus últimos dias do histerismo comum, iniciado em sua juventude. Já antes havia afirmado: “que até os últimos anos de sua vida padeceu Santa Teresa das moléstias de seu mal, provando desacertadamente com uma passagem da autobiografia teresiana, escrita ao menos 17 anos antes da morte da Santa" ${ }^{\text {437 }}$. Sobre o ataque letárgico a que se refere, leia-se em Teresa:

Eu tinha tanta pressa de voltar ao meu mosteiro que fiz com que me levassem para lá nesse estado. Receberam viva, quem esperavam morta. O corpo, no entanto, estava pior do que morto, dando pena vê-lo. Era tamanha a minha fraqueza que posso dizer: tinha apenas ossos. Fiquei nessa condição por mais de oito meses. Mesmo tendo melhorado, fiquei paralítica por quase três anos. Quando comecei andar de gatinhas, louvei a Deus ${ }^{438}$.

Para fundamentar suas afirmações, Perales recorreu às curiosas interpretações do léxico teresiano, da época. Segundo ele, a paralisia da Santa, designava os ataques de histerismo. O mesmo se dá quando ela fala de seu mal de coração: "os desmaios aumentaram, com uma dor no coração de tamanha

\footnotetext{
${ }^{436}$ Cf. ALVAREZ, T. Teresa a contraluz ... p. 15.

${ }^{437}$ Idem. p. $58-59$.

${ }^{438}$ V 6,2 .
} 
intensidade, que todos os que me viam se espantavam" $" 439$, indicando os "acessos de histerismo". Leia-se em Teresa:

[...] vejo que quase nunca estou sem muitas dores, às vezes, bem graves, especialmente no coração, se bem que este mal, antes contínuo, agora é bem raro. Há oito anos curei-me da paralisia aguda e das frequentes febres. Incomodo-me tão pouco com todos esses males que é comum eu ter alegria, porque tenho a impressão de com isso servir ao Senhor de alguma maneira ${ }^{40}$.

E também,

Penei naquele lugar durante três meses, porque o tratamento foi mais forte do que a minha compleição. Em dois meses, graças aos remédios, a minha vida quase chegou ao fim; as dores no coração, de que me fora curar aumentaram tanto que eu às vezes sentia que ele era rasgado por dentes agudos, a ponto de temerem que eu tivesse contraído raiva [...]. ${ }^{441}$

Para Perales, quando Teresa refere-se ao ruído e à fraqueza na cabeça no prólogo das Moradas, isso seria o indício evidente de seu padecimento histérico

Poucas coisas das que me têm sido ditadas pela obediência se tornaram tão difíceis para mim, quanto a de escrever agora sobre coisas de oração. Em primeiro lugar, porque não me parece que o Senhor me dê espírito nem desejo para fazê-lo; em segundo, por ter a cabeça já há três meses com um zumbido e uma fraqueza tão grandes que mesmo os negócios indispensáveis, escrevo a custo $^{442}$.

Contudo, o que afirma o faz em um contexto de alta admiração da Santa, de seu equilíbrio natural e da sua originalidade sobrenatural. Deste modo, é fácil compreender que o livro do Dr. Perales sofresse sorte parecida à Memória do Padre Hahn, ainda que sem o desfortúnio da condenação romana. Na Espanha se fez um silêncio quase total e, na França, Perales encontrou terreno preparado para o frontal rechaço, vindo de um teresianista famoso, o Pe. Gregório de São José, que logo seria um dos mais competentes tradutores do Epistolário e de todas as obras da Santa. O Pe. Gregório publicava no ano seguinte (1895), um estudo sobre a denominada histeria de Santa Teresa, expressando o seu entendimento e a sua resposta ao doutor Arturo Perales, chegava a estas conclusões:

- Que na Santa não existia sintoma característico da preposição histérica;

- Que nela não se apresentam características distintivas da histeria em seu grau menor, ou nas crises ligeiras e, sim, convulsões;

- Que também não apareciam nela sintomas da grande histeria convulsiva;

\footnotetext{
${ }^{439} \mathrm{~V} 4,5$.

${ }^{440} \mathrm{~V} 7,11$

${ }^{441} \mathrm{~V} 5,7$.

${ }^{442}$ Prólogo M 1.
} 
- Que nela não se encontram os sinais característicos de crise histérica.

Estabelecia-se, o debate, apesar da subsequente resposta do Dr. Perales. Deste modo, questiona-se: quem endossaria hoje o antigo diagnóstico charcotiano de grande histeria para Teresa? Contudo, foi a história do Pe. Hahn e do Concurso de Salamanca que colocou Teresa na ótica da psicologia clínica ${ }^{443}$.

Vê-se que na primeira década do novo século, Teresa cruzou com uma dupla corrente de pensamento. Primeiro com a Escola sucessora de Charcot (Freud e a Escola psicanalista). Depois com a corrente teológica do Modernismo. Freud havia se iniciado na Escola de Charcot (século XIX) e estudava o fenômeno do histerismo ${ }^{444}$. Interpreta com chave erótica o fenômeno místico e repassa à psicanálise os estudos do inconsciente, que também se ocupará de Teresa e de seu diagnóstico, enquanto personalidade mística ${ }^{445}$.

Entre tantos estudiosos do caso teresiano, simultaneamente surge no seio da teologia católica a corrente modernista e, nela, quase na penumbra, a tendência a uma nova interpretação da santidade cristã. O máximo expoente dessa nova concepção será o romance $O$ Santo de Antônio Fogazzaro, logo condenado pelo amigo do autor, o Papa Pio $\mathrm{X}^{446}$. O novo santo é um herói leigo. Nesse clima irá surgir, nova versão artística e teatral da pessoa de Teresa, em París. Ali, Teresa é vista como uma heroína laica, refinada e maravilhosa, capaz de internar-se no cárcere da Inquisição, capaz de enfrentar-se com Felipe II e de comandar quem está ao seu lado, com os mesmos fins. Contempla-se, pois A Virgem de Ávila, no

\footnotetext{
443 A prolongada discussão na alternativa entre a enfermidade e a mística foi uma excelente ocasião para aprofundar a personalidade da santa em seu testemunho humana. A polêmica prevalece sobre o diálogo e "o caso teresiano" seguiu aí, intato à espera de uma leitura profunda, metódica e científica. Cf. ALVAREZ, T. Teresa a contraluz ... p. 60-62.

${ }^{444}$ Freud adere à teoria de Charcot e traduz suas experiências e escritos dando continuação à sua pesquisa. Cf. ANDERSON, O. Freud precursor de Freud: estudos sobre a pré-história da psicanálise. Introdução de Elisabeth Roudinesco, Per Magnus Johasson; tradução Luiz Carlos Uchôa Junqueira Fo. São Paulo: Casa do Psicólogo, 2000. p. 71.

${ }^{445}$ Cf. ALVAREZ, T. Teresa a contraluz ... p.62-63.

${ }^{446}$ Il Santo é, pois, um comentário, disfarçado, ficção, da vida católica italiana contemporânea. Seu protagonista, Frei Beneditto, beneditino leigo, entra em contato com os temores supersticiosos, enquanto os Romanos aparecem com um evangelho austero e discreto (espécie de modismo). Beneditto prova, no final, uma morte sacrificial, para ser um instrumento de conversão e de reconciliação. O clímax do livro se dá na entrevista com o Papa. "Santo Padre, [...] a Igreja está gravemente doente. Quatro espíritos malignos entraram no seu corpo, para fazer guerra contra o Espírito Santo. Um deles é o espírito de falsidade [...]. Bons homens são marcados como heréticos e reduzidos ao silêncio, por causa da ação do espírito de falsidade [...]. Tudo que durante séculos tem se tecelado na Igreja é o espírito de dominação do clero. Os que tem espírito de sacerdotes estão insatisfeitos, porque as almas não podem se comunicar na via natural com Deus, [...]". O'CONNELL, M. R. Critics on Trial: An Introduction to the catholic Modernist Crisis. United States of América: Liberary if Cibgress Catalogin. [s.d.] p. 323.
} 
teatro parisiense, muito distanciada da Teresa histórica e, mais ainda, da Teresa dos altares (1906). Um drama do poeta Catulle Mendés (1841-1909), que já o havia proposto na Comédia Francesa (1901). No meio do quinquênio é refeito integralmente, até convertê-lo em sua obra preferida. O personagem dramático de Teresa é vivido por uma das artistas mais célebres de seu tempo: Sarah Bernhardt.

Contudo, talvez não fosse o melhor momento para conceder a Teresa a honra do teatro, particularmente em París, onde a polêmica do século anterior a havia confinado em uma região mal definida entre a mística e a patologia, com caráter de retábulo devoto, ou de clínica experimental. Assim, não era fácil transferí-la poeticamente desde a Salpêtriêre em ópera, ou ao teatro. Além disso, no teatro francês era a hora dos autos sacramentais espanhóis, estilo Lope em sua Vida e Morte de Santa Teresa.

À França Teresa chega no princípio do século XVII. Haviam introduzido-na em Paris dois homens célebres: Bérulle e Richelieu. O cardeal Bérulle trouxe pessoalmente à capital francesa (1604), o Carmelo teresiano e a flor e nata de suas discípulas, as duas Anas. Uma reviverá na obra de Catulle Mendès. O Cardeal Richellieu, tão logo canonizada a santa, dedica-lhe uma grande apoteose, excelente imagem, muito parecida a uma peça teatral. Nessa imagem (1624), o heroísmo de Teresa, recém-canonizada (1622), estava representado por um duplo séquito de personagens em ação: não menos de 26 personagens históricos e outros tantos personagens simbólicos vindos da esfera celeste. Como se Teresa fosse feita de terreno e do ultraterrestre. Agora, ao invés da Virgem de Ávila, Teresa é uma mulher pura, atravessada por altas paixões humanas, não à maneira dos heróis do teatro grego, nem de Édipo ou Medea, mas capaz de colocar-se em uma encruzilhada da história e de fazer girar em torno de sí todo um coro de personagens entre históricos e simbólicos. Tese argumental: Teresa, mulher acima das grandes paixões e misérias humanas. Com toda essa efusão do teatro e da Arte inspirados em Teresa, segue ela adiante da crítica psicólógica em $1908^{447}$.

Deste modo, era natural na passagem do século XIX a XX, que a psicologia pusesse seu olhar em Teresa. Os escritos de então, aparecem já não questionando mais tanto suas enfermidades físicas, mas a estrutura da sua alma, seu eu profundo e pesquisam-na, como diz Tomás Alvarez, até ao subsolo de seu inconsciente.

${ }^{447}$ Cf. ALVAREZ, T. Teresa a contraluz... p. 90-95. 
Aos psicólogos do começo do século, Teresa interessou-lhes, sobretudo, por dois motivos: pelos numerosos fenômenos místicos, algumas vezes vistos como alucinação e, particularmente, pela capacidade de se auto-descrever onde confessa-se, ao leitor, semelhante a um padre, ou a um psicólogo. Assim vê-se nela uma adequada convergência dessas coordenadas, tanto das elevações psicológicas exuberantes com êxtases, arroubos, visões, palavras que ninguém ouve ao seu redor e presságios proféticos, alta capacidade de introspecção e de expressão, numa permanente atitude introspectiva e autocrítica ${ }^{448}$.

Desde seu primeiro livro: Vida, até a última Relação, um ano antes de morrer se mantém alerta sobre si mesma, exigindo-se contas, empenhada em se entender e entender tudo o que se lhe acontecia; reagia a viver sem compreender e seguia escrevendo e descrevendo tudo para que outros a ajudassem a discernir ${ }^{449}$.

O significado desses fenômenos psicológicos, vividos por ela, não chegavam de segunda mão, tampouco eram passados pelo filtro de uma legenda, ou pelo prisma inflacionado de hagiógrafos e devotos, mas chegavam como diamantes brutos, advindo do próprio punho e autógrafo de Teresa. Assim, conforme Tomás Alvarez, depois de quatro séculos ao analista que não podia tê-la em pessoa, podia tê-la bem próxima e polifacética, para lê-la e com lupa de psicólogo, auscutá-la, dissecá-la em seus discursos psicológicos, desde a forma como os relata até chegar-se ao que de fato ocorreu na realidade. Disto decorre-se que, certamente esse conjunto de motivos, dos quais se falava de Teresa, foi o que atraiu o olhar de tantos psicólogos em torno à trama de seus fenômenos místicos ${ }^{450}$. Embora impossível abordá-los todos no maremagnum bibliográfico de escolas, autores e teorias. Adentra-se aqui em alguns.

Um dos primeiros psicólogos da primeira década do século XX foi Henry Delacroix (1873-1937), francês, próximo à anterior Escola de Charcot. Era bom amigo e colaborador de outros altos expoentes da época, como Leuba, Janet, William James, Leroy ${ }^{451}$. Escreveu uma obra: Études d'histoire et de psychologie

\footnotetext{
${ }^{448}$ Ibidem. p. 91.

${ }^{449}$ Idem.

${ }^{450}$ Dela nos chegaram numerosas páginas escritas por sua mão, datadas cronologicamente, sobre o passo-a-passo de seu itinerário evolutivo. Todas de seu período místico. Algumas em gesto reflexivo retrospectivo, outras escritas em seu transe místico. Cf. ALVAREZ, T. Teresa a contraluz... p. 92.

${ }^{451}$ Os nomes de William James, James Leuba, Pierre Janet, Henri Delacroix eram nomes muito importantes no início da nova Psicologia da Religião, aparecem frequentemente em textos e obras. Cf. KRIPAL, J. J. Roads of excess, palaces of wisdom: eroticism and reflexivity in the study of mysticism. Chicago: The University of Chicago. 1962. p. 53.
} 
du mysticismo ${ }^{452}$. Delacroix era professor de Filosofia da Faculdade de Letras de Caen, no norte da França. Publicou sua obra em París, em Alcan Éditeur, no ano de 1908. Sua obra é um trabalho sério e extenso de 470 páginas. A este precedia outro livro seu, importante: Ensaio para a mística especulativa na Alemanha do século XIV (Paris 1899). Agora, no novo livro, propõe-se a abandonar a análise especulativa, ou doutrinal do misticismo e passa ao enfoque da história e da psicologia, como diz o título da obra. Por razões de método e de concretização, reduziu seu estudo a três figuras para deter-se em casos típicos do misticismo católico. Anuncia-os na capa da sua obra: Les grandes Mystiques Chrétiens: Sainte Thérèse - Madame Guyon - Suso ${ }^{453}$. Duas mulheres e um homem: uma espanhola (século XVI), uma francesa (século XVII) e um alemão (século XIV). Só muito rapidamente abordou dois outros mestres: São João da Cruz e São Francisco de Sales, no capítulo VII, mas até mais como teóricos, do que propriamente como testemunhas. $\mathrm{O}$ estudo não só começa com Santa Teresa até a p. 117, como também a Santa segue presente e determinante em toda a obra. De sorte que entre as figuras, típicas do misticismo católico, destaca-se nela: sua vida interior (cap. 1), sua evolução mística (cap. 2), suas palavras e visões (cap. 3). Delacroix faz uma análise séria, penetrante e metódica dos escritos teresianos para chegar, desde eles, à Teresa mesma. Interessa-lhe o confronto do duplo relato, da Vida e das Moradas, um ao começo e outro do final de sua vida mística. Interessam-lhe também as Cartas, se bem que sobre esse título não se referem ao epistolário teresiano, mas às relações maiores. Não conhece a série de graças menores, que também são interessantes desde o ponto de vista psicológico. Quem sabe, por isso, opina que Teresa escreve sempre "souvenirs" (repensando o passado), nunca como “jornal” (relato sobre a marcha). Estranhamente dá importância especial às exclamações, que supõe escritas em data tardía: $1579^{454}$.

Uma dificuldade explícita em Delacroix foi, exatamente, em função da língua, pois o analista, precisa renunciar ao texto espanhol de Teresa para realizar seus estudos através da, segundo Tomás Alvarez, medíocre versão francesa de Bouix. Depois desta, vieram outras mais completas e mais fiéis à redação original,

\footnotetext{
${ }^{452}$ Cf. ALVAREZ, T. Teresa a contraluz... p. 92-93.

453 Tradução: Os grandes místicos cristãos: Santa Teresa, Madame Guyon e Suso.

${ }^{454}$ Cf. ALVAREZ, T. Teresa a contraluz... p. 95.
} 
pois a versão do Pe. Bouix encontrava-se com muitas deficiências. De tal forma que se dizia que as obras de Teresa (de Bouix) estavam mal publicadas:

Que as Obras de Santa Teresa estavam e, sobretudo as cartas, mal publicadas, incorretas e cheias de irreverentes mutilações, é coisa que não se necessita provar, pois tinham manifestado isso muitos espanhóis piedosos, nos censurado os extrangeiros e acabam de nos lançar em rosto os próprios jesuítas belgas e franceses, o fato de tê-la deixado na condução dos bolandistas e do padre Bouix. Ademais, esta evidencia já havia provado o Padre Montoya, no século passado, e isso que ele não chegou a descobrir nem a centésima parte do que sucedia, não podendo desfrutar dos originais, que eu tenho a minha disposição para emendar faltas tão graves ${ }^{455}$.

Deste modo, Delacroix paga tributo a um filtro que possivelmente o distanciou da imediatez entre o juiz e a testemunha, entre o analista e a analisada. Era óbvia a importância do recurso original espanhol para um estudo sério, com objetivo do empreendimento a que se propunha o autor. Contudo, seguem-se aqui, suas principais linhas de visão a respeito da psicologia profunda de Teresa.

Em resumo, os Etudes d'Histoire et de Psychologie du Mysticisme de Delacroix serviram a vários propósitos [...]. Primeiro Delacroix corroborou a observação de Underhill que o misticismo é mais do que a iluminação do êxtase da realidade, é a transformação da realidade. Segundo, ele mostrou que as oscilações são as mais representativas na dinâmica da vida espiritual do êxtase. Em terceiro lugar, nas suas observações de Santa Teresa e Madame Guyon, comprovou os fenômenos perceptivos e comportamentais característicos que vimos em San Juan e Underhill [...] Em quarto lugar, Delacroix quis analisar como esses períodos de negatividade se assemelhavam, ou se diferenciavam em relação à depressão e à neurose. No caso típico dos místicos, longe de renunciar a paralisia [...] se manteve fiel às disciplinas espirituais, pois elas também exibem uma solicitude para servir a Deus, [...] os místicos sempre exploravam seus distúrbios psicológicos para fins espirituais. Por fim, vê-se no quadro de Delacroix que a referência na leitura de testemunhos dos místicos leva a postular a destruição do ego ${ }^{456}$.

Desta forma, primeiramente o autor faz uma releitura dos textos autobiográficos da Santa. E à base deles codifica sua evolução psicológica. Mais que a visão de cada etapa interessa-lhe o processo evolutivo e místico de Teresa. Quanto às duas grandes jornadas na qual a santa crê dividida a sua vida (o antes e

\footnotetext{
${ }^{455}$ SANTA TERESA. Escritos de Santa Teresa: Añadidos e ilustrados por Don Vicente de La Fuente Catedrático de Disciplina Eclesiástico en la Universidad de Madrid. Madrid: RivadeneyraImpressor- Editor, 1862. (Biblioteca de autores españoles desde la formación del linguaje hasta nuestros dias). p. 29.

${ }^{456}$ No original e na íntegra, verificar: AARON, N. G. Thought and poetic structure In San Juan De la Cruz's. Germany: Peter Lang Publishing, 2005. p. 91. (Studies in the humanities. vol 66). [Tradução da autora da tese].
} 
o depois de sua conversão), Delacroix qualifica de contemplativa a primeira e de mística e ativa, a segunda. Contudo, coloca ambas numa descontinuidade ${ }^{457}$.

Assim, a segunda etapa, a dos grandes acontecimentos místicos, fica sensivelmente devedora ao ideario e à ascese, típicos da primeira. Desta forma, para Delacroix as ideias e os exercícios ascéticos não só contemplam conteúdos e tensões sobre as vivências místicas posteriores, mas também as geram, condicionam e as alimentam. Deste modo, a vida ascética de Teresa soa como a que produz a sua vida mística. Na realidade, não é assim que se dá, pois lendo-a no contexto de suas obras pode se ver melhor ${ }^{458}$. Veja-se, por exemplo, na introdução da Obra do Castelo Interior de Teresa, feita por Tomás Alvarez :

Materialmente, o processo de vida espiritual descrito no livro divide-se em dois tempos, que poderíamos assim definir: ascético o primeiro, místico o segundo. A luta ascética, cujo protagonista é o homem, estende-se ao longo das moradas I-II-III; a vida mística, protagonizada pelo divino ator, predomia nas moradas V-VI-VII. Entre ambos os grupos, as moradas quartas são o vínculo, jornada em que se imbricam o natural e o sobrenatural ${ }^{459}$.

Conforme Delacroix, o segundo estágio é o que lhe interessa. O psicólogo gradua-o em etapas, condicionadas pelos estados de oração. Assim a oração teresiana fica como se fosse um ambiente, ou um estado de sonho, como uma espécie de sonolência psicológica, com a tendência a dissociar-se das realidades externas, sensoriais, em busca do sobrenatural. Delacroix repetirá em sua obra insistemente esse dado, em cima de um erro de percepção, ao afirmar que a oração é sempre um estado de sonho, que se desenvolve em sonolência mística, ou em um sonambulismo psíquico (hipnose sacra). Assim para ele, Teresa, em sua peculiar escala de experiência mística, passa por cinco etapas:

- sensação de ingresso na presença de Deus, precedida pelo estado de oração contemplativa;

- passividade na oração de quietude, nos estados intermitentes;

- estados de êxtases no qual o inconsciente perde-se a sí mesmo;

- estados de sofrimento místico, produzidos pela reclamação do exterior mundano, ou sensorial, ainda não superado e pelo atraso na obtenção da meta mística;

${ }_{458}^{457}$ Cf. ALVAREZ, T. Teresa a contraluz... p. 94-96.

${ }^{458}$ Idem.

${ }^{459}$ ALVAREZ, T. Introdução. In: SANTA TERESA DE JESUS. Obras Completas... p. 437. 
- estado de união mística com Deus, na qual se produzem as falas e visões místicas e a identificação da consciência com o Tu divino ${ }^{460}$.

Em seus estudos sobre Santa Teresa, Madame Guyon, São Francisco de Sales, São João da Cruz e Henrique Suso, Delacroix afirmou que o místico possui uma aptidão peculiar que se fundamenta numa riqueza extraordinária da vida subconsciente. Segudo ele, o místico serve-se dos processos fisiológicos e psicológicos de forma excepcional, inclusive dos automatismos e intuições do subconsciente, na transformação total de sua personalidade. Assim, longe de ser um exemplo de empobrecimento, dissociação ou psicose, as sucessivas etapas da vida do místico representam uma nova e criativa forma de existência ${ }^{461}$.

Torna-se, assim, uma graduação convencional, mas não aderente ao relato e a auto-análise teresiana, apenas mais adptável a um prévio esquema psicológico.

A cronologia das primeiras etapas é correta (Teresa estreia a vida mística aos quarenta anos). Menos correta é a data de ingresso na etapa final. Delacroix chega a pensar que Teresa em 1577 descreve as sétimas moradas, antes de havêlas vivido. Porém de qualquer forma, cada etapa produz a seguinte, ou se abre sobre ela como uma flor que se torna fruto. Simples processo endógeno e indutivo. Algo assim como a psicologia do adolescente normal deriva no comportamento do adulto. Tese concluída, ainda que Teresa pense o contrário $^{462}$.

Quanto ao interesse de Delacroix, a respeito das palavras sobrenaturais e visões de Teresa, estuda-as analisando primeiramente as palavras interiores.

Uma vez, ao rezar as Horas, voltando de novo essa tentação, cheguei ao versículo que diz: Justus es, Domine, em seus juízos e comecei a pensar quão grande verdade é essa [...]. Quando pensei que, com justiça, permitíeis a muitas servas Vossas como eu disse, seguir sem os consolos e graças que me concedíeis, sendo eu quem era, Vós me respondestes: serve-me e não te envolvas nisso. Foi a primeira palavra Vossa que ouvi, o que muito me espantou ${ }^{463}$.

Nesta parte, Delacroix analisa Teresa como um caso de pessoas que ouvem palavras sem que alguém as diga. Mas Tomás Alvarez, diz: ela não ouve palavras exteriores. Não as ouve sensorialmente. As ouve dentro de sí $^{464}$. São palavras nítidas e, de certa forma, construtoras da própria psique, quando as recorda, diz: me espantou muito. Ou seja, surpreende-se porque as ouve. Contudo, não a identifica ao interlocutor, mas ela mesma encarrega-se de uma análise finíssima, propondo-se a discerní-las dos automatismos sugestivos da psiqué. Experimenta as como palavras de outra pessoa nela. Como palavras que obram, que produzem

${ }^{460}$ Cf. ALVAREZ, T. Teresa a contraluz... p. 96.

461 ÁVILA. A. Para conocer la psicologia da religión... p. 23.

${ }^{462}$ ALVAREZ, T. Teresa a contraluz... p. 97.

${ }^{463}$ V $19,9$.

${ }^{464}$ ALVAREZ, T. Teresa a contraluz ... p. 97-98. 
o que dizem, como palavras que fixam-se indelévelmente na memória, no fundo do psiquismo, de origem sobrenatural ${ }^{465}$. Assim, segundo ela:

Parece-me que uma pessoa, encomendando a Deus uma coisa com grande afeto e preocupação poderia imaginar que ouve dizer que a coisa se cumprirá, ou não. [...]. Se for uma coisa criada pelo intelecto, por mais sutil, cedo se perceberá se é ele que organiza e fala. O que distingue esses dois modos é a diferença entre elaborar um discurso e escutar o que outra pessoa diz; o intelecto percebe que não escuta[...]. Quando o intelecto age, podemos distrair-nos e, se estivermos falando, calar-nos; quando Deus fala, isso não é possível[...] o Senhor parece querer que se compreenda que Ele é poderoso e que as Suas palavras são obras $^{466}$.

Ao psicólogo, contudo, mesmo com o discernimento de Teresa as palavras que ela ouve não passam de automatismos do subconsciente que:

dependem de uma prévia situação anímica de apremiantes desejos e apontam teleológicamente a um objetivo não consciencial, porém vital. Forjadas no subconsciente, afloram à consciência. Portanto, são alucinações. Não "alucinações psico-sensoriais", mas "alucinações que os psicólogos chamam psíquicas"[...]. Se Teresa as percebe como heterônomas, como vindas de outro, é porque para o eu consciencial, ou subconsciente é percebido como "outro"467.

Contudo, para Tomás Alvarez, a série de estados místicos descritos pela santa não são fenômenos isolados e desconexos e

Formam uma "suíte" [...] espécie de evolução progressiva, presidida por uma coerência secreta, não de ordem lógica racional, mas organizada pelos automatismos do poderoso subconsciente teresiano. A força criadora do subconsciente é a que em um primeiro período místico a faz superar a frustração intelectual e imaginativa da meditação (o "não poder discorrer", não poder representar-se a Cristo paciente", etc.), suplantando o discurso lógico com a intuição contemplativa $^{468}$.

Desta forma, nota-se notar que é a intuição contemplativa que produz o primeiro sentimento místico da presença de Deus. Ao não poder representá-lo na meditação, a intuição mística a faz emergir desde o subconsciente. Contudo, o crescimento desse Deus interior à base de locuções e visões pessoais, corre o risco de um distanciamento do Deus tradicional, com derivações heterodoxas. Teresa salva-se desse risco com a introdução em sua vida mística, do fator bíblico e eclesial, precedentemente incorporado à mente. E, deste modo, realiza a unidade das duas forças contrárias, contemplativa e ativa ao permitir que sua vida mística

\footnotetext{
${ }^{465}$ Idem.

${ }^{466} \mathrm{~V} 25,3$.

${ }^{467}$ ALVAREZ, T. Teresa a contraluz... p. 98.

${ }^{468}$ Idem.
} 
desemboque na intensíssima necessidade operativa de se colocar a serviço de seu Deus interior.

Delacroix é breve quanto ao conteúdo moral desse longo processo psicológico e refere-se a ele como se o estado de êxtase teresiano tivesse realmente eliminado o eu consciente, com consequências passageiras, ou mais sérias. Mas Teresa encontra-se num estado mais elevado e de mais íntima união com Deus. Ao unir-se ainda mais inteiramente a Ele, suas ações se fortalecem nessa união, tanto nas pulsões interiores, quanto nas ações exteriores.

A Igreja legitima seus estados místicos, reconhecendo-os como reais, não como fictícios, ou psicológicos ${ }^{469}$. E a monja explica, em sua doutrina, a mística e os termos relacionados à mesma, para tantos cristãos, como no exemplo, abaixo.

Eu queria saber explicar, com o favor de Deus, a diferença que há entre união e arroubo, ou enlevo, ou vôo que chamam de espírito, ou arrebatamento, que são uma coisa só. Digo que esses diferentes nomes se referem a uma coisa só que também se chama êxtase. É grande a vantagem que ele tem diante da união. Produz efeitos muito maiores e vários outros benefícios, porque a união parece ser igual no início, no meio e no fim e o é no interior; mas esses outros fins alcançam um grau mais alto, manifestando-se seus efeitos tanto no interior, como exteriormente ${ }^{470}$.

Outro aspecto expresso na opinião de Delacroix é que Teresa chegou a uma plenitude psicológica. Não se pronuncia sobre a questão ética e não incorre no extremismo de outros psicólogos coetâneos e amigos seus, que qualificam Teresa deficitária em aspectos de ordem moral. Como James H. Leuba, por exemplo.

Delacroix tem uma posição determinística empírica, naturalista e nega qualquer valor transcendental na experiência mística, afirmando que os místicos evidenciavam grande tendência para a simplificação e a unificação da forma. Tal admiração por elee que os compara aos gênios dos artistas e inventores. $\mathrm{Na}$ psicologia de misticismo religioso (1925), Leuba afirma que a pessoa espiritual é a psicologicamente motivada pelas mesmas tendências e necessidades de qualquer outra pessoa: sobrevivência, adaptação e a busca de uma melhor vida. Para De Leuba, o místico é um auto-hipnotizador e procura na relação com os outros uma vida melhor ${ }^{471}$. Por isso, apresentará expressamente o problema: chegou Santa Teresa a obter seus objetivos morais? E a este responde categoricamente que não.

\footnotetext{
${ }^{469}$ Ibidem. p. 101.

${ }^{470}$ V 20,1.

${ }^{471}$ Para verificar o original: AARON, N. G.Thought and Poetic... p. 91
} 
Ao contrário, afirma que ela chegou ao cume do orgulho, da pertinência, da marginação a respeito da ordem moral, da autosuficiência no plano social.

São conclusões que certamente não descreveria Delacroix. Contudo, em sua análise psicológica de Teresa resulta este perfil: Teresa é profundamente alucinada. Desde o ponto de vista subjetivo sofre uma constante e crescente auto-sugestão, reesctruturadora de sua personalidade. Desde o ponto de vista objetivo é vítima de um espelhismo colossal, que introduz no deserto de sua vida terrestre o fictício paraíso dos deuses ${ }^{472}$.

Como se observou no início, aqui não se trata de analisar o parecer do primeiro olhar dos psicólogos frente à Teresa de Ávila. Apenas constatar. Contudo, pontua-se que, pelo fato da psicologia ser, ainda nascente nessa época e os próprios diagnósticos da ciência ser passados por uma profunda revisão, muita coisa, inclusive para o olhar da psicologia, veio a se tornar diferente, ao modificar-se na história, suas estruturas e enquadramentos. Dado que a teoria na qual os teóricos se embasam, condiciona tendências frente ao olhar em questão.

O que fica claro aqui é que o conhecimento que hoje se tem de Teresa, a compreensão teológica e a compreensão da Igreja em relação a ela são muito distantes da Teresa que aparece nesta esfera, considerada como real. As aproximações ao diagnóstico, quando a pessoa mesma está presente na clínica facilita a aproximação à vida e ao desenvolvimento psicológico. Aqui não só falta a pessoa real de Teresa, para a análise, feita por outras mediações, vê-se que em alguns trechos faltaram os meios adequados: melhor tradução, ferramentas ainda não completamente desenvolvidas na ciência e na psicologia, facilitando distorções de sua vida e obra que influenciavam os diferentes pareceres e trouxeram Teresa de Ávila à clínica de uma forma inadequada a ela mesma e ao papel que representa no lugar que ocupa na Ordem Carmelita, na vida da Igreja e na vida da sociedade.

Para Tomás Alvarez a Teresa das análises realizadas não corresponde à, dos escritos, dos caminhos e das fundações, das obras por ela mesma deixadas. Pois frente à mulher de sentido comum, escritora, andarilha, executiva na vida prática, “a Teresa do psicólogo parece uma imagem robótica, não é a Teresa que foi comunicada em seus escritos"

\footnotetext{
${ }^{472}$ ALVAREZ, T. Teresa a contraluz... p. 101.

${ }^{473}$ Ibidem. p. 102.
} 
Nas armadilhas da análise psicológica de Delacroix ao negar-se a conexão de Teresa com um Deus real, ou ainda, sem a devida referência à realidade de Deus, determinantes para sua psicologia, a doutrina de Teresa e de suas experiências místicas tendem a se esvaziar, a se transformar em ilusão, como diria Freud. No entanto, frisa-se aqui a importância de considerar-se o próprio testemunho de Teresa em suas obras e em seu discernimento, quando diz:

É completamente impossível que isso seja imaginação; isso a nada leva. [...] não poderiam ser concebidas pela imaginação por serem muito mais sublimes, como eu já disse, do que se pode compreender no mundo[...]. Se fosse produzido pelo intelecto, isso não deixaria os grandes efeitos de que falei, nem geraria frutos ${ }^{474}$

Seria a linha de Teresa razoável a ser seguida. Quem sabe, por isso, um bom conhecedor da Teresa real, Gregório Marañon, referindo-se a esses laboratórios de finais do século XIX e aos começos do XX, escreverá prolongando o teresiano livro das fundações:

Foi este um dos pecados mais graves de nosso século XIX[...]Inclusive se falou, através de pessoas que se supunham representantes da ciência de que a vida de Teresa pertenceu à patologia[...]. Basta ler a vida da Santa, quando ainda era uma simples mulher para se dar conta do processo heróico de sua luta, até conseguir a escravidão de sua carne mortal flutuando sem peso de sua alma sublimada pelo sacrifício ${ }^{475}$.

E complementa Tomás Alvarez:

Querer catalogar esta sobrenatural desrealização, desumanização da pessoa, entre as enfermidades do espírito é tão absurdo que não valeria a pena recordálo se não fosse porque esse absurdo corre pelos livros, todavia. [...]Toda a vida de Santa Teresa foi colocada em comunicação com o mais além, como uma ânfora de cristal, transparente e aberta, incapaz de reprimir nada, nem de converter em anormalidade o reprimido ${ }^{476}$.

Desta forma o leitor, ou o historiador que se aproxima de Teresa à altura de 1921 está munido de recursos para o devido reconhecimento da Santa, para refazer seu semblante, seus feitos, sua vida, sua morte e conseguir captá-la com maior sensibilidade. Poderá penetrar em seu interior, sondar seus sentimentos e suas intenções, dispondo de um documental mais copioso e autêntico do que as obras mais próximas à vida de Teresa, num tempo onde havia pouca pesquisa e as

${ }^{474} \mathrm{~V} 28,11$

${ }^{475}$ ALVAREZ, T. Teresa a contraluz... p. 103.

${ }^{476}$ AUCLAIR, M. Prólogo da versão francesa do livro das fundações, París 1952. In: ALVAREZ, Tomás. Teresa a contraluz... p. 104. 
poucas obras que se tinham chegavam ao pesquisador de modo duvidoso. Contudo, hoje já são mais confiáveis ${ }^{477}$.

Houve um importante psiquiatra e psicanalista que se chamava Cazal. Este quis esboçar o claro-escuro da imagem teresiana. Quando o coração de Santa Teresa foi extraído para relíquia, Madre Catalina, priora do Convento de Alba de Tormes, falou que o coração de Teresa tinha uma cicatriz, de mais ou menos dois centímetros ${ }^{478}$. Perguntavam-se todos:

De onde pode ter vindo esta cicatriz? Poderia tratar-se, pensavam alguns, de um infarto de miocárdio, que haveria coincidido com a famosa experiência da transverberação, porém assinalam os especialistas dos fenômenos místicos, que é muito difícil admitir que uma visão intelectual tenha podido provocar uma lesão corporal $^{479}$.

Inúmeras explicações eram imaginadas. Cazal interessou-se pelo caso:

Edmond Cazal se documentou meticulosamente sobre o tema, obteve autorização para visitar vários carmelos e o Padre Silvério de Santa Teresa que era nessa época um dos maiores especialistas em Santa Teresa, se prestou amavelmente a ajudá-lo com sua erudição e seu crédito. Seu livro não seria pior que tantos outros, se alguns elementos não tivessem perturbado ao leitor $\operatorname{advertido}^{480}$.

Em seu capítulo intitulado Misticismo, histeria, auto-erotismo, no qual descreveu em dezesseis páginas problemas complexos, Cazal afirma que Teresa nunca teve vocação religiosa, que se tivesse casado e levado uma vida normal, não teria sido enferma e não teria sido obrigada a práticas pueris e supersticiosas dentro de um convento. Para Cazal, Teresa é histérica, como todos os demais místicos. Mas a maior surpresa de suas pesquisas, ainda não é este entendimento. Esta chega em seu epílogo, quando diz: Teresa foi enterrada vida, teve a extirpação do coração e um martírio póstumo ${ }^{481}$. Segundo o relato de Cazal:

Imediatamente após a morte de Teresa, o padre Gracián viajou com pressa até Alba de Tormes para raptar o corpo da Santa e enterrá-lo em Ávila [...] lhe

\footnotetext{
477 Já viu à luz o copioso dossiê documental reunido pelo P. Silvério nos seis primeiros volumes da "Biblioteca Mística Carmelitana" (Burgos, 1915-1919). Depois os três volumes publicados na BAE, por Vicente de la Fuente. Para os franceses já foram publicados sua edição documental das carmelitas de Paris, mais uma boa e metódica "Bibliografia Teresiana", de Henri de Curzon (París, 1902). Em inglês se publicou seis volumes documentais B. Zimmerman. Também biografias sérias e bem documentadas de M. Mir na Espanha, ou de Henry Joly, na França. Dossiê bibliográfico semelhante ao que se preparava a celebraçao do iminente terceiro centenário da canonização de Teresa. Cf. ALVAREZ, T. Teresa a contraluz... p. 105-106.

${ }^{478}$ PEREZ, J. Teresa de Ávila: y la Spanã de su tiempo. Madrid: Algaba Ediciones, 2007. p. 148.

[Tradução da autora da tese].

479 Idem.

${ }^{480}$ Idem.

${ }^{481}$ Ibidem. p. 148-149.
} 
ocorreu deixar em Alba uma relíquia especial: o coração. [...] Ao chegar à noite, na presença unicamente das irmãs conversas Catalina Bautista e Maria de Santo Alberto perfura a madeira e tira o caixão[...], descobre o corpo e com uma faca atravessa o peito para extrair-lhe o coração. Para sua surpresa brota sangue da ferida que acabava de fazê-la, o que demonstraria que Teresa ainda estava viva, o padre Gracián a tinha matado inadvertidamente. Em 04 de outubro de 1582, acreditavam-na morta, quando na realidade estava somente cataléptica, como lhe tinha ocorrido em agosto de 1539 [...]. Nove meses mais tarde, o Pe. Gracián volta a Alba, oficialmente desta vez, para proceder a exumação ${ }^{482}$.

Segundo Tomás Alvarez, o problema não está macabra intervenção atribuída ao personagem que mais amou e admirou a santa, Frei Jerônimo Gracián, mas no pano de fundo do seu relato. Na interpretação do perfil de Teresa, nas suas qualidades: humana e feminina. Referindo-se a Cazal, assim se expressa:

A Teresa que no livro se oferece ao leitor é uma mulher profundamente anormal minada por uma radical frustração humana em sua condição de mulher. Braceando e lutando contra si mesma, Teresa vai incubando e amadurecendo um histerismo que não a libera de sua hipersensibilidade carnal. Ao contrário a submerge em uma voluptuosidade ("volupté" é o vocábulo preferido de Cazal)[...]. De modo que o histerismo dela contagia, ou provoca o histerismo coletivo de suas seguidoras ${ }^{483}$.

Tomás Alvarez conclui que tudo poderia ser compreensível na pluma de um Cazal psiquiatra, ou psicanalista, se alcançasse seu objetivo primeiro de ser um historiador. Mas ao vê-lo pagar tributo ao diagnosticar como mórbido a mística e tudo o que as fontes apresentam, inclusive as escritas por Teresa, expressa: ${ }^{484}$

O critério apriorístico do autor consiste em qualificar de radicalmente doentios a todos os místicos, incluído expressamente frei João da Cruz: "Todos os grandes místicos mulheres e homens, são grandes histéricos. A força de seu misticismo está na proporção direta da gravidade de sua neurose" ${ }^{\text {485. }}$.

Desta forma, conclui que se o psiquiatra consegue combinar à personalidade de Teresa um filão de fundo que começa na histeria, passa pela deformação da religiosa, culmina na catalepsia e conclui-se no enterro da monja viva, seguido ainda de seu assassinato, onde lhe arrancam o coração, essa admirável sequência muito bem concatenada, presta-se muito bem ao mais admirável romance, não porém à factibilidade da história ${ }^{486}$. O autor Perez, conclui sobre o texto de Cazal:

Portanto, nos cuidaremos bem de tomar a sério as elucubrações do comandante Cazal sobre a morte de Santa Teresa. Se pensei que devia mencioná-las é para

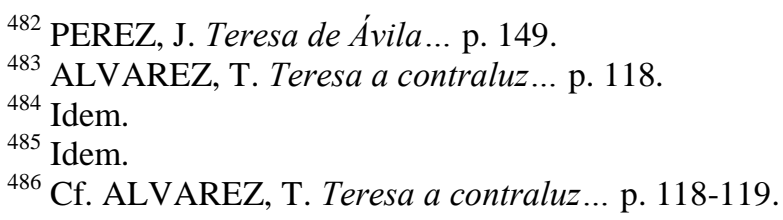


demonstrar como a partir de uns poucos elementos de difícil interpretação, uma imaginação fértil pode construir uma autêntica novela. Para explicar a cicatriz no coração de Santa Teresa, a hipótese mais verossímel segue sendo uma ferida causada por mãos inexpertas no momento da extração ${ }^{487}$.

Ao leitor de hoje, à distância de quase um século, interessa conhecer o impacto produzido nos leitores dos anos anteriores pelo sensacional livro de Cazal, tão copiosamente difundido pela "Sociedade de Edições literárias e artísticas" e pela "livraria Ollendorf" de Paris ${ }^{488}$. Contudo, de fato a obra é lida mais como romance do que como propriamente história. E apesar da reiterada pretensão do autor de apresentar seu estudo absolutamente histórico frente às flagrantes manipulações e tergiversações dos historiadores precedentes, sua obra intitula-se: O romance de Santa Teresa por Edmond Cazal. Para Etchegoyen:

O que nos oferece o Senhor Cazal é um romance de amor, romance de voluptuosidade, de sangue e de morte. Um romance passional, evocador das encenações românticas de Catulle Mendés[...] o relato fabulado de Cazal incorre em numerosas contradições, se desinteressa das fontes históricas[...] omite intencionadamente a referência aos documentos, inclusive quando cita a Teresa mesma: "não tem direito a fazer dizer a Santa Teresa o que ela jamais quis $\operatorname{dizer}^{489}$.

Em conclusão para Etchegoyen o livro de Cazal, mais que história é uma síntese das teorias psicologistas do momento. A tese de Leuba sobre a erotomania de Santa Teresa e as afirmações de Havelock Hellis sobre seu auto-erotismo, "necessitavam ser transladadas a um livro que pusesse em manifesto todos os seus pontos fracos: é o serviço que nos prestou, sem querê-lo, o senhor Cazal”490.

Os sérios transtornos que começaram a atingir a Santa Teresa, com a idade de dezesseis anos, [...] estando intimamente ligados, sem dúvida[...] ao medo e "histeria", mas não há consenso exato[...]. Enquanto Malthus e Georges Dumas, percebem uma relação estritamente histérica, Pierre Janet considera que ela foi uma psicastênica e que, por assim dizer, aspira a histeria. Ou seja, procura um automatismo da ação que nunca consegue atingir. (Discussão na Société de Psychologie, Revue Scientifique, 12 de maio, 1906) ${ }^{491}$.

\footnotetext{
${ }^{487}$ PEREZ, J. Teresa de Ávila... p. 149.

${ }^{488}$ Basta recolher o eco de duas vozes mestras, uma francesa e outra espanhola. Na França um hispanista e teresianista de primeira linha, o célebre Gaston Etchegoyen. Na Espanha, um estilista insigne, Azorin (José Martinez Ruiz). São dois bons conhecedores da pessoa de Teresa e de todo o tema teresiano. Etchegoyen, membro da Escola dos Altos estudos hispânicos, escreveu "as fontes literárias de Teresa" em 1923. Azorin é por sua vez, um literato apaixonado de Santa Teresa de Ávila. Cf. ALVAREZ, T. Teresa a contraluz... p. 119.

${ }^{489}$ Ibidem. p. 120.

${ }^{490}$ Idem.

${ }^{491}$ Tradução da autora da tese. Para verificar o original, veja-se: ELLIS, H. The soul of Spain. Boston: [s.e], 1915. p. 101.
} 
Azorin, nesse mesmo ano de 1921, publica suas impressões num novo livro sobre Santa Teresa na imprensa periódica madrilenha. Tem palavras de boas vindas para o autor parisiense que esteve na Espanha. Para aquele que viveu as mesmas paragens da santa, que percorreu os mesmos caminhos, em carros lentos, ou nos mesmos carros, nos quais a santa viajou, aquele que morou nas pousadas dos povos. Diante do relato do cavalheiro francês, sente-se incomodado ao ler que Teresa nunca teve vocação religiosa. Por isso, escreve:

No livro do Senhor Cazal se tenta criar uma variante no caráter de Santa Teresa. Esta é a primeira novidade da obra[...]. O exame da mulher de Ávila está feito desde um ponto meramente humano. $\mathrm{O}$ autor insiste em fazer ressaltar na psicologia da Santa Teresa, a parte da vontade, da dominação, suave, porém inflexível, de jovialidade honesta, sadia e animadora. E chega a escrever que Santa Teresa nunca teve vocação religiosa. A frase é um pouco atrevida. Como, pois se explica a prodigiosa obra realizada pela grande mulher ${ }^{492}$

E mais adiante, ao ler sua obra e deparar-se com novo deslize:

"Depois de uma vida de luta e de esforços formidáveis, já morta Teresa, assistimos a um espetáculo de um interesse dramático extraordinário. Não entramos a examinar, discutir[...] nosso trabalho é puramente informação. Fatos são os que expõe o autor a falar da morte de Santa Teresa e do que aconteceu depois, que devem ser considerados friamente e com toda a determinação. $\mathrm{O}$ autor, contudo, recarrega as tintas do drama e se compraz em um lirismo terrível e emocionante"[...] E aí está o livro, tremendo e trágico, de Edmondo Cazal. Que temos de crer? Que precisamos rechaçar? ${ }^{493}$.

Assim, vê-se que a historiografia de Teresa realizada por Cazal foi mal sucedida. Contudo, enquanto visão laica da santa incorpora avanços das ciências psicológicas do momento, traduz as valorações do quadro místico teresiano considerado pela época e mostra ser uma versão que reage aos precedentes biógrafos que impuseram a Teresa jargões piedosos e deformaram de seu perfil histórico. Cazal passa ao extremo oposto e lhe aplica critério clínico-mórbido radical despojando-a de sua vida mística, religiosa e de seu equilíbrio humano. Segundo Etchegoyen a sua é uma Teresa de camarim, cortada à medida, para servir em uma aula de neurologia, porém inútil para uma classe de história ${ }^{494}$.

Em síntese, ao visto neste ponto, no terceiro centenário de morte de Teresa de Ávila (1880-1882), com sede em Salamanca, Espanha, lançou-se um concurso para pessoas de dentro e de fora do país, com o objetivo de maior brilho

\footnotetext{
492 ALVAREZ, T. Teresa a contraluz ... p. 121..

${ }^{493}$ Ibidem. p. 121-122.

${ }^{494}$ Cf. ALVAREZ, T. Teresa a contraluz ... p. 121-122.
} 
e realce ao centenário, maior estruturação e obtenção de um maior número de obras, incluindo as científicas, em torno da santa.

A memória premiada no concurso foi a do Padre Guillermo Hahn, professor de fisiologia, com seus estudos sobre os fenômenos histéricos e as revelações de Santa Teresa. Baseou-se no tema da histeria, fundamentando-se com nova teoria de Charcot e defendeu a tese de que Teresa era histérica, mas que, devido ao fato de ser santa, teve preservada algumas de suas funções, distinguindo-se das demais histéricas. Padre Hahn foi delatado à Roma, que interviu, condenando sua obra ao Index. Com o rechaço recebido, deixa a congregação religiosa e sai muito aborrecido com tudo o que lhe ocorreu.

Perales foi o médico que recebeu o segundo lugar no concurso. Sua obra: Os êxtases, raptos e enfermidades da santa ante a ciência, foi publicada e sua tese, de semelhante modo, não alcança explicação conveniente, recebendo a sorte de seu colega anterior, contudo sem a condenação romana. A tese defendia que em Teresa as paralisias, as dores de cabeça e o mal de coração afirmavam-se na sua histeria, apenas fisiológica e tinha duas fases estabelecidas no diagnóstico de Charcot, a epileptiforme e a clownica, mas não as duas posteriores das atitudes passionais e delírio.

Além da histeria, outros psicólogos, psiquiatras e psicanalistas enquadravam Teresa à psicastenia, epilepsia, loucura e como não bastasse tanta polêmica em relação aos fenômenos da sua vida, inclusive a hora da morte ficará polêmica, até Cazal expressar que Teresa não morreu naturalmente, mas assassinada!

Entretanto seu caso não contemplou somente opositores, mas também muitos defensores. Alguns psicanalistas tentaram uma primeira aproximação entre a ciência, a psicologia e a mística, como Jaime De Luba, Henry Delacroix, mas até então o diálogo entre a ciência teológica e a psicologia não chegavam a um suficiente e adequado entendimento. $\mathrm{O}$ que chega um pouco mais além até o momento é William James.

\section{3}

\section{A Mística de Teresa vista por alguns olhares da Psicologia atual}

Sabe-se que a psicologia, enquanto saber científico se abre às novas descobertas zelando com que a produção científica tenha rigorosa e meticulosa 
qualidade de comprovação. No capítulo II, viu-se como a teologia é considerada ciência. Entretanto, por lidar com um saber que nem sempre materialmente pode ser comprovado, encontra em parte da psicologia, às vezes certa resistência, no que diz respeito à percepção e à orientação religiosa, pois não sabendo se explicar, cientificamente, fenômenos acabam desconsiderados, ou concebidos como anticientíficos. Contudo, para o olhar da ciência e da psicologia atual, já mais interessado na busca da contribuição mística e da própria Teresa, tornam-se estes mais interessantes. Abaixo há duas abordagens atuais: lacaniana e junguiana que fazem frente a esse diálogo e demonstram essa busca da ciência.

\subsection{1}

\section{Teresa e a Psicanálise Lacaniana}

Como se viu no capítulo anterior, a psicanálise lacaniana adentra na interface com Teresa e com a mística, sobretudo, a partir de sua abordagem, métodos, linguagem e gozo. No psicanalista Denis Vasse vê-se esse avanço, dado ser ele um estudioso da santa e deixar, na sua abordagem, entrever-se a evolução da leitura psicanalítica no diálogo com Teresa e com a mística ${ }^{495}$.

Vasse reflete sobre a ação de Deus no relato da vida de Teresa de Ávila:

Daqui, em diante é um novo livro, isto é uma vida nova. A que levei até aqui era minha; a que passei a viver depois que comecei a falar dessas coisas de oração é a que Deus vive em mim. Porque entendo que era impossível sair por mim mesma em tão pouco tempo de costumes e ações tão más. Louvado seja o Senhor que me livrou de mim mesma ${ }^{496}$.

Para Vasse, a diferença entre a vida de Deus em Teresa, em oposição à própria vida, marca-se pelos efeitos e pelos atos. Na conclusão da santa: "vivendo em nós, pela oração, Deus nos liberta de nós mesmos, de nossa imagem que julgamos ser a dele" ${ }^{\text {497, }}$ Vasse visualiza o caminho que se abre através do Encontro. De um encontro que é também nascimento do sujeito. Teresa dirige a palavra a partir de um encontro, cujo lugar é a carne e cujos efeitos são a oração, a quietude e o êxtase. Ou seja, no re-pouso e na saída de si. Para o psicanalista, esses efeitos são os mesmos de todo o encontro amoroso no qual a re-posição de

495 Cf. VASSE, D. Leitura psicanalítica de Teresa de Ávila. Tradução Nadyr de Salles Penteado. São Paulo: Loyola, 1994.

${ }^{496}$ V 23,1 .

${ }^{497}$ V 23,1ss. 
si no outro, fora de toda confusão e sedução pode ser sentida como o próprio dom da vida. Desta forma, a vida minha, a que recebi como dom soberano, é minha, mas é também dom do outro, da humanidade, de Deus. De modo como

o filho recebe a sua humanidade do Pai que dá a vida. O homem chega ao conhecimento desse dom[...] atinge o dom da vida que lhe é feito, à medida que deixa de impedir que a Majestade do Doador se revele à alma "em sua Santíssima Humanidade, para que a conheça plenamente e nada ignore do dom soberano que recebe. [...] O homem se vê onde ele se perde de vista - em Deus ${ }^{, 498}$.

O autor também refere que, por ter mudado sua vida, num contínuo movimento de conversão, Teresa cativa as pessoas a entender e a buscar essa mudança. Desta forma, a santa empresta sua voz e sua linguagem para ser testemunha do quanto a obra de Deus pode operar na vida de cada um. Vasse escuta a sua voz. É o psicólogo a que se acenava no capítulo anterior, a quem além do padre, Teresa se abre e se confessa. Ao ouvir as confidências de Teresa, ressuscita o texto, pois a voz de Teresa é uma voz que fala e ao mesmo tempo, escuta. Assim, para Vasse, não é nem a compreensão intelectual, nem a análise histórico-crítica, mas o método empregado é o que penetra no coração do que diz Teresa, porque o coração de Teresa é um coração que, antes de servir-se da linguagem, escuta e percebe. Deste modo, na análise de Vasse destacam-se, sobretudo dois pontos. Primeiro: o recolhimento do material deixado por Teresa na história, nos significantes da sua história, incluindo a localização das repetições, percebidas nas mudanças no relato, mudanças que se referem a algum acontecimento, ou ainda, sobrevindas no seu trajeto de oração, de contemplação, ou do trabalho do espírito nela. Estas variáveis acarretam decisões e provocam a determinação do desejo. O segundo ponto é verificar o trabalho entre o espírito de Teresa e a ação do Espírito Santo. Ambos alavancam o desejo de Teresa de dar lugar, de submeter-se e obedecer ao espírito do Mestre. D’Aquele que fala, ordena e toma nela o espaço de uma morada ${ }^{499}$. Quanto ao compreendido na leitura psicanalítica por colegas anteriores, como alucinações de Teresa, Vasse diz:

Trata-se de metáforas, não de alucinações. Como sempre, em tais casos, os efeitos do símbolo, no sentido lacaniano de um vínculo vivo e originário entre Real e o Imaginário, revelam uma terceira ordem, a Simbólica, na qual está contida a estrutura $^{500}$.

\footnotetext{
${ }^{498}$ VASSE, D. Leitura psicanalítica... p. 16-17.

${ }^{499}$ Cf. ORAZIO, M. J. Convite a ler Teresa. In: VASSE, D. Leitura psicanalítica... p. 9-10.

${ }^{500}$ VASSE, D. Leitura psicanalítica... p. 160.
} 
Lembra-se, aqui, o segundo capítulo, no qual se falou sobre a transgressão da palavra e que, para o místico, a palavra fica aquém de tudo aquilo que experimenta e vivencia na relação com Deus, pois o vocabulário se empobrece e não dá conta de exprimir a realidade do sagrado. Assim, também para o entendimento do psicanalista Denis Vasse, o termo metáfora é o que melhor cabe naquilo que antes se lia como alucinação em Teresa. Vasse completa:

O que a metáfora indica escapa à representação imaginária. Com ela, o jogo dos significantes remete ao sujeito que não é, justamente, da ordem da representação ou do significado. Não se trata aqui de uma compreensão "objetiva" que informasse sobre os objetos em questão, nem tampouco de uma operação puramente intelectual separada da densidade do corpo; assim se percebe, às vezes, na palavra "espírito" 501 .

Deste modo, torna-se uma unidade e a metáfora não fica estranha à experiência dos sentidos. Como diz Teresa, o "corpo muitas vezes participa" "502. Porque a experiência do espírito é, acolhida e vivida num corpo, onde também se acolhe a verdade que se revela no corpo, onde o espírito se manifesta ${ }^{503}$. Segundo Vasse, quando o homem se abre ao que fala nele, toma corpo na verdade ${ }^{504}$.

Com isso, Vasse valoriza o espiritual no humano, com o seu ser e com seu corpo. É também a luta de Teresa para expressar o que se passa nesse centro do coração, que escapa a todo conhecimento consciente. O que não deixa de ter relação com a verdade que fala no espaço da interioridade de cada um. Assim,

No mais íntimo do íntimo, esse "lugar" só poderia remeter a uma alteridade absoluta, a um Outro, sem outro. Essa maneira de debater põe necessariamente em jogo uma contradição, na ordem do discurso, quando este tem por "objeto" o sujeito que fala. Por em prática essa contradição. Porém, não é "mentir". É, ao contrário, dizer a verdade, como podemos; dizê-la, ao passo que é ela que fala em cada um, quando eu, por minha vez, jamais seria capaz de dizê-la senão pela metade. Só podemos, diz Lacan, meio-dizê-la. Esse meio dizer - no plano teórico - ainda não é a mentira ${ }^{505}$.

Desta forma, Vasse acena a questão da verdade e da mentira, outra presente no núcleo do ensinamento teresiano sobre a oração e concebida como caminho no qual a pessoa encontra a verdade que fala nela.

Também ainda em relação ao "outro", este outro é o sinal (o símbolo) de Deus que vem ao nosso encontro, "fazendo-nos sair da imagem de nós mesmos,

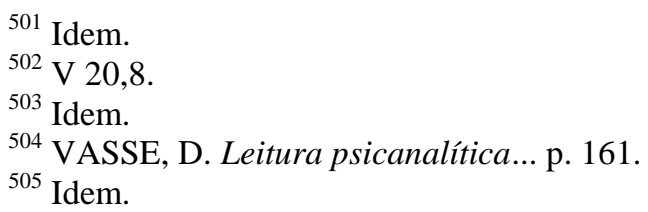


fazendo-nos "ex-sistere" de nosso imaginário pervertido e fechado sobre si mesmo" 506 .

Este sair de si-mesmo que Vasse irá denominar de passagem do homem psíquico ao espiritual, que se encontra na verdade, e se dá, na relação com o Outro é o que Teresa refere como conversão, encontro com Deus e com os irmãos.

Essa passagem do homem psíquico ao homem espiritual, determinada na alternância e na mudança de sentido do desejo (com que limita o Real) é marcada por Teresa, em sua autobiografia, com o sinal da alteridade: não é mais o livro da sua vida que ela escreve, mas o de um outro ${ }^{507}$.

Assim para Vasse, quando o Espírito de Verdade fala no lugar da alternância do desejo, o imaginário abre-se ao Real. Para Teresa, a vida como imagina, abre-se à Vida que a faz viver: é a vida do Deus Trinitário "que habita no mais íntimo da alma"508. Assim, quando Deus introduz o mundo da alma humana no mundo que lhe é peculiar e quando o Seu Mundo se torna o mundo humano, o mundo próprio da pessoa, “compreendemos que a alma não é um recanto escuro, mas o lugar em que o mundo se ilumina, com a luz original que aparece na noite" ${ }^{, 509}$. E, "como habitualmente não a vemos, podemos crer que não existe outra luz interior, senão a que vemos e que dentro de nossa alma há uma certa escuridão" ${ }^{\text {, }}$. Contudo, quando o Deus de Jesus Cristo se une à pessoa pela palavra e pela carne de seu Filho "a alma tornada cega e muda, como foi o caso de São Paulo em sua conversão ${ }^{511}$, não entende mais nada, pois todas as potências estão alienadas ${ }^{512}$.

Nota-se aqui, que alienação nem sempre significa problema, alheamento, mas pode significar o contrário: efeito da concentração, da acolhida à presença de Deus. Quanto à questão problemática da histeria, do entendimento defendido por alguns representantes da psicologia e psicanálise, tão polêmica à vida póstuma da Teresa, como se viu anteriormente, Vasse tem novamente outra opinião. Expressa-se, afirmando que os termos de histeria elou psicopatia não cabem à Teresa, sobretudo, por serem feitos ante a uma certa antecipação,

\footnotetext{
${ }^{506}$ Ibidem. p. 161 .

${ }^{507}$ Idem.

508 7M 1,3.

${ }^{509}$ VASSE, D. Leitura psicanalítica... p. 161.

${ }^{510} 7 \mathrm{M} 1,3$.

511 At 9,8.

${ }^{512} 7 \mathrm{M}, 1,6$.
} 
Em nome de nossa sabedoria humana quanto à psiquiatria, nós a classificaremos nas produções "histéricas", ou psicóticas"[...] sem nem mesmo nos dar ao trabalho de perguntar o que chamamos, com erudição de "histeria", ou de $\operatorname{psicose}^{513}$.

É outro olhar que, por sua vez, remete a outros conceitos e enquadramentos. Teresa, já havia sido referência para a tese do próprio Lacan em uma de suas obras mais famosas, O seminário, Livro 20, Mais, ainda. Nela Lacan fala sobre o fenômeno místico e sobre Teresa. Aborda-os sob o ponto de vista do gozo. Diz Lacan: "basta que vocês vão olhar em Roma a estátua de Bernini para compreenderem logo que ela está gozando, não há dúvida. E do que é que ela goza?"514 Em seguida, acrescenta: "é claro que o testemunho essencial dos místicos é o de dizer que eles o experimentam, mas não sabem nada dele" ${ }^{\natural 15}$.

Assim para Lacan, Teresa "goza", mas não sabe do que goza. Talvez não saiba exprimir o quanto goza e, como diz ele, não obstante a "seus expectadores estarem ávidos de uma resposta", para saber do que está gozando ${ }^{516}$.

Tais expectadores e suas demandas de saber sobre esse gozo levaram os protagonists a discorrerem por longas páginas, narrando, detalhadamente suas experiências. Resta, entretanto, sempre mais a dizer, ou a escrever e eles, frequentemente apresentam essa idéia em suas produções, num tom de quem quase se desculpa com o interlocutor ${ }^{517}$.

Desculpam-se por não terem conseguido palavras para expressar todo o significado do símbolo, porque para a mística de fato não há palavras suficientes para explicá-la. Fica a linguagem devedora à experiência realizada.

Ao referir-se aos fenômenos que caracterizam a clínica da psicose, Lacan fala na atitude da crença radical do sujeito, frente à existência de estranhas realidades que aparecem através da alucinação e do sistema delirante. No Seminário sobre as psicoses, diz: "O sujeito admite[...] que esses fenômenos são de uma outra ordem que o real, ele sabe bem que a realidade deles não está assegurada, admite mesmo até certo ponto a sua irrealidade" ${ }^{\text {}} 18$. Desta forma, a partir da proposta psicanalítica lacaniana, o sintoma e a loucura, podem ser entendidos enquanto formação do inconsciente que se estrutura na linguagem.

\footnotetext{
${ }^{513}$ VASSE, D. Leitura psicanalítica... p. 19.

${ }^{514}$ LACAN, J. J. O seminário, livro 20, Mais, ainda. Rio de Janeiro: Jorge Zahar, 1985. p. 103.

${ }^{515}$ Idem.

${ }^{516}$ Cf. NUNES JUNIOR, A. B. Extase e clausura... p. 90.

${ }^{517}$ Ibidem. p. 91.

${ }^{518}$ LACAN, J. O Seminário Livro 3: As psicoses. Rio de Janeiro: Jorge Zahar, 1988. p. 91.
} 
Essa estrutura significante é a substituta do significante recalcado. A esse respeito Jacques-Alain Miller, ao definir sintoma, expressa-se assim:

uma formação do inconsciente que tem estrutura de linguagem, que supõe uma substituição, a qual chamamos de metáfora, em linguagem de retórica e que por aí, fica aberta ao deslocamento retroativo por reformulação e a uma modificação pelo fato da emergência de efeitos de verdade ${ }^{519}$.

Deste modo, a metáfora, enquanto sintoma de loucura, de histeria, ou de obsessão, difere-se da metáfora mística porque, enquanto língua do recalque traz o sintoma inerente ao campo da neurose e se coloca como resposta metafórica à falta, estabelecida pela castração. Já na metáfora mística a própria metáfora tende a inaugurar outra dimensão para além do significante, o que Lacan denomina: gozo. Esta se dá na medida em que falta para o sujeito a palavra última sobre a sua verdade, sobre o seu ser, fazendo-o adentrar-se à inscrição fantasmática, mas este gozo significa complementação e não assinalação da falta sintomática. Assim,

Para o primeiro, o acesso ao gozo de completude não ocorre, como não poderia deixar de ser, só que o sujeito atribui a sua não ocorrência à fatalidade de se deparar somente com objetos insatisfatórios, ao longo de sua penosa existência. Colette Soler observa que "a histérica é pouco mística, ao contrário do que imaginam todos, que vendo-a em crises, convulsões e tudo o mais, pensam logo nas místicas como histéricas", isto quer dizer que a histérica está presa em demasia à estrutura significante e a seus efeitos, enquanto que a mística mergulha, por assim dizer, no inominável do gozo ${ }^{520}$.

Ao discernir Lacan que a histérica está presa à estrutura do significante e a seus efeitos, enquanto a mística mergulha no inominável do gozo, encontra-se na teoria lacaniana uma amostragem do quanto a ciência, ao apropriar-se das vivências misticas, pode encontrar caminhos e facilitar a aproximação ao diálogo particularmente entre a mística e a psicologia atual, propiciando novas interpretações psicológicas e novos espaços para o fenômeno místico e seus efeitos, senão a patologia, ou inadequação. Deste modo a mística poderá ser compreendida na esfera do real, como algo possível e aos olhos da ciência ${ }^{521}$.

Portanto, para Lacan, os místicos distintamente dos sintomas e fenômenos patológicos experimentam a idéia de que deve haver um gozo que esteja mais

\footnotetext{
${ }^{519}$ MILLER, J. A. Algumas reflexões sobre o fenômeno psicossomático. In: WARTEL, R. Psicossomática e Psicanálise. Rio de Janeiro: Jorge Zahar, 1990. p. 208.

${ }^{520}$ NUNES JUNIOR, A. B. Êxtase e clausura... p. 89.

${ }^{521}$ Idem.
} 
além do que o gozo comum de se experimentar ${ }^{522}$. Por isso, o psicanalista relaciona o gozo do místico ao gozo da mulher .

Se se concebe um Deus que goza, a natureza de seu gozo é aquela do Outro gozo, do gozo da mulher[...]. Não se pode dizer tudo sobre a mulher. [...] enquanto significante da falta, faz supor um vazio, remete ao inominável, aponta para os limites do simbólico - nem tudo pode ser dito, alguma coisa escapa ao discurso ${ }^{523}$.

Desta forma, o lugar do vazio a que o significante Deus remete, aglutina em torno de si, todo o questionamento humano em relação ao sentido da vida e às regras que comandam o funcionamento do universo. Até mesmo em relação à insatisfação residual que acompanha os seres falantes e faltantes, decorrente da perda de gozo instituída pela inscrição do significante. Assim, falta à linguagem o significante que unificaria tudo e o divino, sem nome, aparece para presentificarse à lacuna em relação à ausência de uma significação última das coisas ${ }^{524}$. O que pode ser nominado por Lacan de gozo do corpo. Assim,

Alguns místicos, convictos da transcendência de suas experiências de união mística com o divino, asseguram ter experimentado esse gozo pleno, no corpo, fato, aliás, que a estética barroca difundiu amplamente, incitando os fiéis a trilharem pelos mesmos caminhos, de seus heróis espirituais[...]! O místico conforma-se ao outro divino ${ }^{525}$.

\subsection{2}

\section{Teresa e Jung}

A perspectiva de Jung surge no contexto da necessidade de se relativizar a psicanálise freudiana e suas possíveis fontes filosóficas: o pragmatismo de William James e a perspectiva de Friedrich Nietzsche. Por esta razão, o caráter hermenêutico da psicologia analítica aparece no final do século XIX, início do $\mathrm{XX}$, centrado na busca de novas abordagens do inconsciente (o incognoscível).

Desde a clínica psiquiátrica da Universidade de Zurique, Jung procura aplicar um modelo experimental, próprio das ciências teórico-experimentais, com uma base não tão objetiva como na psicanálise freudiana, baseada num modelo interpretativo e nas leis de associação de palavras que interelacionam conteúdos conscientes à sua origem inconsciente. Jung serve-se de outros modelos, como:

\footnotetext{
${ }^{522}$ Lacan, J. O seminário, Livro 3... p. 102.

${ }^{523}$ NUNES JUNIOR, A. B. Extase e clausura... 95.

${ }^{524}$ Ibidem. p. 95-96.

525 Ibidem. p. 96.
} 
$1 \mathrm{O}$ modelo estético-artístico, que mostra diferentes significados da origem, desperta à imagem, à criatividade e à criação, processadas no inconsciente. Em 1912, em Símbolos das Transformações, define a existência de dois tipos de pensamento: pensamento dirigido à linguagem (ligado à linguagem verbal, próprio da consciência) e pensamento fantasia (de caráter imagético, característico do inconsciente). Essa distinção realça o método de análise verbal e a promoção de técnicas que privilegiam a linguagem própria e imagética do inconsciente. Deste modo, busca não impor lógicas gramaticais ao inconsciente, mas deixá-lo expressar-se mais livremente $e^{526}$.

2 O modelo da formação e desenvolvimento da personalidade foi desenvolvido em Tipos Psicológicos (1921). Basea-se na concepção da psique como um organismo auto-regulador com a tendência de evitar o desequilíbrio e promover o desenvolvimento das funções psíquicas. Dele surgem os conceitos de compensação, unilateralidade e reflexão sobre opostos ${ }^{527}$.

3 O modelo místico-religioso de Jung tem suas fontes em Kant, na teologia mística, no romantismo alemão e na alquimia. Sustenta-se por uma análise conceitual religiosa e filosófica. Dá ênfase ao incognoscível, ao autônomo e ao emocional dos conteúdos inconscientes. Na constelação dos arquétipos subjazem analogias religiosas e místicas da abordagem do inconsciente, conforme ilustrado na obra: Psicologia e Vida Mística de Leon Bonaventure ${ }^{528}$.

Léon Bonaventure, baseando-se em C. G. Jung, serve-se de Teresa de Ávila e de suas obras, como a de outros autores cristãos, para defender a tese de que uma análise psicológica, dentro de uma perspectiva cristã, pode ser o caminho para o reencontro da experiência mística. Bonaventure aproxima o Si-mesmo de Jung, ao arquétipo do Centro da Alma do qual fala Teresa, no Castelo Interior ${ }^{529}$.

Assim, o centro se alcança com longo processo de ascese e de autoconhecimento. O Si-Mesmo, torna-se o lugar onde, ao mesmo tempo tudo nasce e para o qual tudo converge. Deste modo é a conversão de Teresa análoga ao homem psíquico de Jung, que em seu processo de metanoia, caminha em direção ao Self ${ }^{530}$. Neste sentido,

\footnotetext{
${ }_{526}^{526}$ Cf. BONAVENTURE, L. Psicologia e vida mística... p. 106.

${ }^{527}$ Idem.

${ }^{528}$ Idem

${ }^{529} \mathrm{Idem}$.

${ }^{530}$ HALL, C. S.; NORDBY, V. J. Introdução à Psicologia Junguiana... p. 43.
} 
O self contém não só o depósito e a totalidade da vida passada, como é ainda um ponto de partida, o solo fértil do qual brotará toda a vida futura. Essa premonição do porvir está tão claramente impressa nos nossos mais fundos sentimentos quanto o aspecto histórico ${ }^{531}$.

O Self para Jung é o Si-mesmo, principal arquétipo e centro de toda a personalidade. Dele emana o potencial energético que a psique dispõe e nele ordenam-se os processos psíquicos que, ao integrar e equilibrar aspectos do inconsciente deixa no humano uma sensação de unidade. O Si mesmo representa a realização de sua totalidade e individualidade. O arquétipo do Si-Mesmo, com seus símbolos específicos retornam à superfície nos momentos de dificuldades, de crise, em forma de símbolos, ou sonhos. O conhecimento que o eu tem sobre o $\mathrm{Si}$ Mesmo aflora nos aspectos de auto-imagem e auto-estima ${ }^{532}$.

As imagens teresianas e de outros santos podem ser consideradas símbolos. Na mística teresiana aparece água, céu, árvores, inferno... um dos mais centrais nas Moradas é o castelo. Conforme Lyra, a imagem das primeiras moradas, onde a alma aparece como uma pessoa muda e surda que, progressivamente, desperta e vira-se à luz do sol, faz analogia com o mito da Caverna de Platão ${ }^{533}$.

Desta forma e por este caminho de similaridades, pode se ver que antigas tradições deram como herança para a humanidade seus símbolos e arquétipos. Estes, por sua vez, seguem comunicando-os com mensagens e a vida, para os que vêm depois. O símbolo não se esgota e dá, ainda, orientação ao centro que os une e os relaciona entre si. Por este motivo a psicologia que leva em conta o sagrado basea-se nisso e propõe que a pessoa, em sua busca de auto-conhecimento, aprofunda, se inter-relacione e se introduza no caminho, dando seguimento à sua iniciação e reestabelecer a conexão pessoal com a unificação do ser

a psicologia sagrada realiza simbolicamente rituais de iniciação e de passagem, originários das antigas tradições. Essa abordagem que vê a iniciação como o aprofundamento de si mesmo, a entrada no mundo obscuro e desconhecido da psique, o caminhar para a ponte que liga o mundo humano da multiplicidade e da manifestação ao mundo da totalidade arquetípica não-manifesta, ao mundo dos deuses, ao Self - propõe que o homem se torne um iniciado. O processo iniciático da psicologia sagrada é um caminhar em direção ao centro psíquico e

\footnotetext{
${ }^{531}$ DOWNING, C. (Org). Espelhos do Self: As Imagens Arquetípicas que Moldam a sua Vida. São Paulo: Cultrix, 1994. p. 14.

${ }^{532}$ Cf. HALL, C. S.; NORDBY, V. J. Introdução... p. 43.

533 LYRA, S. R. Psicologia e vida mística. Jornal da Universidade. Ed. 147 março 2012. Disponível em http://www.ichthysinstituto.com.br /artigosdetalhe. asp?ID=77. Acessado em 25.08.2012, às $14 \mathrm{~h}$.
} 
espiritual, onde é possível a identificação com a Consciência Una, numa experiência de ligação com o universo e de participação na totalidade ${ }^{534}$.

Assim, segundo a compreensão junguiana, se para Teresa a alma é um castelo aonde se dão as coisas mais sagradas, ela serviu-se da imagem para descrever toda a realidade inexprimível do encontro do Si mesmo com Deus, com a imagem, com a vida e com o universo. Deste modo é que a mística tem essa íntima relação com a experiência simbólica ${ }^{535}$.

Assim, símbolos que se referem ao mundo interior transportam significação psicológica, no sentido de ser útil e necessária à vida e orientam comportamentos, relacionados ao eu pessoal, às emoções humanas e a inter-relação com os demais. Por isso é que para Jung todo símbolo, ainda que individual, corresponderá a um símbolo universal. Deste modo traduz-se a experiência mística em categorias emprestadas da psicologia.

Deste modo, também, para este trabalho, pinçam-se alguns dentre os conceitos considerados fundamentais na teoria junguiana e opta-se por acenar a quatro símbolos relacionados à Teresa: sombra, self, individuação e integração.

A sombra para Jung encontra-se no inconsciente. Quando a pessoa deparase com o inconsciente, depara-se com a sombra que é a que contém os aspectos não desenvolvidos da personalidade, as possibilidades $\mathrm{e}$ as intenções inconscientes da alma. Nem sempre é fácil reconhecer e aceitar a sombra. Muitas vezes, pode-se projetá-la sobre outras pessoas. Contudo,

Quando o ego e a sombra trabalham em perfeita harmonia, a pessoa sente-se cheia de vida e de energia. O ego canaliza, em lugar de obstruir, as forças emanadas dos instintos. A consciência expande-se e a atividade mental fica cheia de vivacidade e vitalidade. E não somente a atividade mental: a pessoa também se sente mais ativa e vigorosa. ${ }^{536}$.

E, se de um lado para Jung a sombra é o lado negativo da personalidade, a soma das qualidades desagradáveis que o humano esconde, aliada às funções insuficientemente desenvolvidas e ao conteúdo do inconsciente pessoal (aspecto individual da sombra), por outro Jung mesmo sugere a ligação com o inconsciente coletivo. Nele, a sombra pode ser representada inclusive pelo demônio, muito

\footnotetext{
${ }^{534}$ CAVALCANTI, R. O Retorno do Sagrado... p. 201.

$5351 \mathrm{M}, 1,1$.

${ }^{536}$ HALL, C. S.; NORDBY, V. J. Introdução à Psicologia Junguiana ... p. 41.
} 
embora, segundo Dante Moreira Leite, "na lenda popular, o demônio seja descrito como figura sem sombra" 537.

Jung, também denomina de anima e animus à imagem da alma do outro sexo no inconsciente de cada um, com a função complementar, ou compensatória de, ao propender a consciência numa direção, fazer o inconsciente tender à direção oposta. Isso, conforme Jung é o que equilibra as forças interiores ${ }^{538}$.

Todo homem leva dentro de si a imagem eterna da mulher, não a imagem desta ou daquela mulher em particular, mas sim uma bem definida imagem feminina. Esta imagem é fundamentalmente inconsciente, um fator hereditário de origem primordial gravado no sistema vivo e orgânico do homem, uma impressão, ou arquétipo de todas as experiências ancestrais da fêmea, um depósito, por assim dizer, de todas as impressões deixadas pela mulher [...]. Sendo inconsciente, tal imagem é sempre projetada na pessoa amada e constitui um dos principais motivos da atração apaixonada, ou da aversão ${ }^{539}$.

Assim o que Jung afirma é que o homem herda a sua imagem de mulher e inconscientemente estabelece padrões que influem na aceitação, ou rejeição do feminino. A primeira projeção da anima é feita na mãe e a do animus, no pai. Mais tarde é projetada em seus pares. Assim, quando se experimenta uma atração apaixonada, significa que o arquétipo inverso encontra-se em seu inconsciente os mesmos traços de sua imagem de anima, ou de animus. E, quando sente aversão, é porque as imagens estão dotadas de conflitos com seu anima, ou animus $e$ nelas há características que lhes são próprias ${ }^{540}$ :

Jung afirma que a anima tem um apreço preconcebido por tudo o que é fútil, desamparado, incerto e não intencional numa mulher. $\mathrm{O}$ animus prefere identificar-se com homens heróicos, com intelectuais, com artistas ou com atletas célebres $^{541}$.

Outro aspecto interessante é perceber que :

O desequilíbrio entre persona e a anima, ou o animus, pode ter como corolário o desencadeamento de uma rebelião da anima, ou do animus, caso em que a pessoa reage exageradamente. $\mathrm{O}$ rapaz pode acentuar a anima a ponto de se tornar mais feminino que masculino.

Self é outro conceito elementar na teoria de Jung e refere-se ao conceito de personalidade total (ou psique). Esta totalidade, não se obtém colocando as partes

\footnotetext{
${ }^{537}$ LEITE, D. M. (Org. da série). Estudos em Psicologia. São Paulo: Editora UNESP, 2009. p. 243.

${ }^{538}$ HALL, C. S.; NORDBY, V. J. Introdução à Psicologia Junguiana... p. 76.

${ }^{539}$ Ibidem. p. 39.

${ }^{540}$ Idem.

${ }^{541}$ HALL, C. S.; NORDBY, V. J. Introdução à Psicologia Junguiana... p. 40.
} 
lado a lado, à maneira de um quebra-cabeça, mas está presente desde o começo, embora leve tempo para amadurecer ${ }^{542}$. Assim,

O princípio organizador da personalidade é um arquétipo a que Jung deu o nome de Self. $O$ Self é o principal arquétipo do inconsciente coletivo, assim como o sol é o centro do sistema solar. O self é o arquétipo da ordem, da organização e da unificação; atrai a si e harmoniza os demais arquétipos e suas atuações nos complexos e na consciência, une a personalidade, conferindo-lhe um senso de "unidade" e firmeza. Quando uma pessoa declara sentir-se em paz consigo mesma e com o mundo, podemos estar certos de que o arquétipo do self está exercendo com eficácia o seu trabalho. Por outro lado, quando se sente "fora dos eixos" e insatisfeita, ou num conflito mais sério e tem a impressão de que "desmorona", é porque o self não está atuando de modo conveniente ${ }^{543}$.

Nota-se que a meta final de qualquer personalidade é chegar a um estado de auto-realização e de conhecimento do próprio self. Uma tarefa demorada, difícil e que raramente ou, até mesmo nunca, pode ser completamente realizada por quem quer que seja. Para Jung, os grandes líderes religiosos, como Jesus e Buda foram os que mais se aproximaram dessa meta ${ }^{544}$.

Conforme a observação de Jung, o arquétipo do self só se torna evidente na maturidade, visto ser preciso que a personalidade chegue ao pleno desenvolvimento para que o self possa tornar-se manifesto de modo, mais ou menos, completo $^{545}$.

Neste sentido o auto-conhecimento para Jung, através do alcance do self inconsciente é caminho para a realização humana. Assim, para se auto-realizar é preciso conhecer-se e trazer o inconsciente ao consciente, porque

Tornando consciente o que é inconsciente, o homem pode viver em maior harmonia com a própria natureza. Ficará menos irritado e frustrado, pois haverá de reconhecer as origens destas coisas no próprio inconsciente. A pessoa que não conhece o próprio self inconsciente projeta nos outros os elementos reprimidos do próprio inconsciente[...]. A consciência de si revela tais projeções [...]Seu relacionamento com os demais indivíduos melhora e ele se sente mais em harmonia com eles e consigo mesmo ${ }^{546}$.

O conceito de individuação na teoria de Jung é o processo através do qual o ser humano evolui de um estado infantil de identificação para um estado de maior diferenciação. Com isso, a pessoa se identifica menos com os valores vividos pelo meio e mais com as orientações provenientes do próprio Si-mesmo. Assim:

\footnotetext{
${ }^{542}$ Ibidem. p. 43.

${ }^{543} \mathrm{Idem}$.

${ }^{544}$ Idem.

${ }^{545}$ HALL, J. A.; CABRAL, A. Jung e a interpretação dos sonhos: manual de teoria e prática. 9. ed. São Paulo: Cultrix, 2005. (Coleção estudos de Psicologia Junguiana por Analistas Junguianos). p. 43.

${ }^{546}$ HALL, J. A.; CABRAL, A. Jung e a interpretação dos sonhos... p. 44.
} 
Individuação é um conceito central na teoria jungiana. Refere-se ao processo em que uma pessoa na vida real tenta consciente e deliberadamente compreender e desenvolver as potencialidades individuais inatas de sua psique[...]. O fator importante, por conseguinte não é a soma de realização, mas se a personalidade está sendo fiel às suas próprias potencialidades mais profundas, em vez de simplesmente ceder às tendências egocêntricas e narcisistas, ou de se identificar com papéis culturais coletivos ${ }^{547}$.

Jung pontua momentos que delimitam o processo de tornar-se indivíduo. As diferentes etapas do processo mostram se em cinco etapas descritas abaixo:

Primeira: individuação. É a integração da sombra; Segunda: integração do animus-anima. Onde se articula o feminino e masculino como alteridade pessoal. Adolescência e terceira idade são momentos favoráveis para essa harmonização; Terceira: encontro do indivíduo consigo mesmo. Identificação profunda com o eu mais profundo, descobrimento do self; Quarta: relação com a sabedoria (saborear e valorizar o que de fato tem valor); Quinta: relação com o transcendente. Com o numinoso, que não se conhece, mas que atrai. Todas não em momentos não lineares, mas cíclicos, em espiral, em forma elíptica ${ }^{548}$.

Quando o ego resiste ao processo de individuação identifica-se com estruturas do inconsciente desarmonizadas com o processo mais amplo de individuação. Gera-se, aí uma neurose, sensação de se estar dividido internamente. Exemplo: se alguém vive um papel na família atribuído-lhe na infância, pode significar tanto a neurose, como a tentativa de evitar o avanço para os estágios seguintes, isso fixa o indivíduo em um nível mais antigo e, também,

A identificação com um papel social (identificação com a persona) mesmo considerando que esse papel seja aceito e bem recompensado por vasto segmento de uma sociedade, não é individuação. Jung considerou que Hitler e Mussolini exemplificaram tal identificação com as figuras oriundas do inconsciente coletivo, que esta conduziu a ambos e a nações inteiras à tragédia $^{549}$.

Cada pessoa deve ser considerada única no processo de individuação. Jung assinala essa profunda importância e valor da vida humana, pois para ele,

Essa prioridade está refletida nas grandes religiões mundiais, mas falta em muitos movimentos modernos de massa, onde o indivíduo é reduzido a uma unidade social, econômica, ou militar. Nesse sentido, a individuação constitui

\footnotetext{
${ }^{547}$ Ibidem. p. 25.

${ }^{548}$ CABARRÚS, C. R. Crescer bebendo do próprio poço. 2. ed. São Paulo: Loyola, 2004. p. $144-$ 145.

${ }^{549}$ HALL, J. A.; CABRAL, A. Jung e a interpretação dos sonhos... p. 26.
} 
um contraponto à ameaça de perda de valor humano num mundo que está excessivamente organizado em bases tecnológicas, ou ideológicas ${ }^{550}$.

Quanto à religiosidade, pode-se dizer que Jung manteve grande interesse pela experiência religiosa. Dedicou-se ao estudo de religiões orientais e entendeu a alquimia como prática religiosa e psicológica não ortodoxa explorando rituais de transformação que encontrou ainda ativos no seio da tradição cristã ocidental.

Já que o Si mesmo se apresenta fenomenologicamente com as mesmas imagens que tem sido associadas com frequência à divindade, ele funciona, em certa medida, como uma imagem de Deus dentro da psique. A relação entre essa imagem e aquela referida pela especulação teológica como Deus é, de fato, uma questão em aberto, embora não seja frequentemente debatida. Experiências sobrenaturais ocorrem em alguns sonhos e parecem ser capazes, se assimiladas, de produzir profundas e duradouras alterações, na estrutura da personalidade, um efeito paralelo a algumas conversões religiosas e a certas experiências culminantes na vida vígil ${ }^{551}$.

Assim,

O processo de individuação, tal como é entendido na teoria junguiana e encorajado na análise, envolve um diálogo contínuo entre o ego, como o centro responsável pela consciência e um misterioso centro regulador da psique total, centro a que Jung chamou de Si-mesmo - tanto o núcleo do ego como o que o transcende, necessitando do ego para que se desenrole o processo de individuação, aparentemente separado e independente dos estados de ego ${ }^{552}$.

Há sempre uma totalidade no indivíduo (conjunto das instâncias psíquicas: persona, sombra, self, etc. $\mathrm{O}$ indivíduo alcança sua personalidade individual à medida que a pessoa se desenvolve e a meta de desenvolvimento da psique é a consciência dessa totalidade. Para Jung o processo de individuação da pessoa não é conflitivo com o meio em que o indivíduo se encontra, mas condição para ele adaptar-se e inserir-se com sucesso dentro de seu ambiente, tornando-se aí um membro ativo. Poucos indivíduos alcançam a meta da individuação de forma mais ampla. A individuação se dá em etapas e acompanha a da assimilação em suas quatro funções (sensação, pensamento, intuição e sentimento) ${ }^{553}$.

Uma análise junguiana "bem-sucedida" leva à apreciação da natureza fundamentalmente misteriosa da psique, a qual parece ser ao mesmo tempo íntima e transpessoal, limitada pelo ego individual e, no entanto, mais livre no tempo e no espaço do que a personalidade empírica. Nesta fronteira da psique

\footnotetext{
${ }^{550}$ Idem.

551 Ibidem. p. 26-27.

552 Ibidem. p. 27.

${ }^{553}$ HALL, C. S.; NORDBY, V J. Introdução à Psicologia Junguiana... p. 87.
} 
estamos no limiar de questões culturais mais vastas, que não podem ser respondidas exclusivamente pelo insight clínico ${ }^{554}$.

Em suma, quanto aos aspectos de relacionamento entre a teoria junguiana e Teresa de Ávila pode se ver nos conceitos acima colocados, que a mesma usa a imagem do castelo interior para representar um caminho ao encontro com o divino dentro de si. Em um nível psicológico, esse caminho compara-se ao processo de individuação de Jung e ao seu núcleo mais profundo, o self de Jung, ao qual toda a pessoa tem a meta de alcançar. Nas três primeiras moradas, de Teresa encontra-se a primeira fase da individuação que fala Jung e as três últimas moradas podem se assemelhar à segunda fase de individuação de Jung, mais receptivas e internas.

A primeira morada, na qual Teresa refere que as pessoas, estão fora de sua própria casa, relaciona-se à falta de auto-conhecimento a que Jung acenava. A segunda, de forte chamado interior e onde há luta e hesitação, à tensa relação entre o interior e o exterior de Jung. A terceira ao inconsciente vindo aos poucos à consciência. Assim, vê-se que na doutrina de Teresa é possível visualizar o ego e o self aproximando-se e distanciando-se, em correspondência à primeira fase do processo de individuação junguiana e, na quarta morada, em diante, vê-se a segunda fase, na qual a pessoa lança-se mais profundamente em direção a Deus e aos outros e descobre, a própria essência, como na teoria junguiana. A quarta morada para Teresa é de transição. Na primeira fase do processo junguiano desenvolve-se a personalidade e tenta encontrar o equilíbrio entre as necessidades da família, as da sociedade e os ideais de cada pessoa. Relacionada às primeiras moradas, nelas também há o processo de individuação, conforme descreve Jung, enquanto exercício do encontro e da relação. Em Teresa, esse exercício com vistas a fortalecer a consciência, o ego, a auto-afirmação da personalidade e a definição da identidade pessoal, se dá particularmente, por meio da oração.

A auto-imagem atual cria na pessoa nova vaidade associada à necessidade de fazer progressos. Começa a reconhecer as próprias projeções e percebe a sombra. Os aspectos que Teresa denomina conversão são os aspectos negativos de Jung que precisam ser deixados para trás para ir-se ao alcance do self e trazê-lo ao consciente. Todo o potencial interior empenha-se em promover melhorias pessoais e coletivas. Tema chave na obra do psicanalista Jung, conhecido como,

${ }^{554}$ HALL, J. A.; CABRAL, A. Jung e a interpretação dos sonhos... p. 27. 
metanoia. Assim, para Jung, como para Teresa a vida tende a um fim e tem um significado, um sentido existencial. Com isso, a metanoia de Jung, a conversão e busca de perfeição de Teresa tornam-se alavancas legados para a posteridade.

\section{4 \\ CONCLUSÃO}

Na passagem do século XIX ao XX, a teologia traça um perfil novo para um santo cristão. Neste, Teresa é apresentada como heroína secular, que enfrenta Felipe II, atravessa cavernas da Inquisição, outra Joana d'Arc, à moda espanhola. Sua fortaleza torna-se referência para gerações, pois a mística é sem fronteiras.

Os escritos de Padre Hahn arremessaram Teresa, desde o olhar da ciência da época, ao pente fino do crivo científico da história. Neste interín recebe diagnósticos psicanalíticos de louca, psicastênica, histérica, epiléptica, e outra infinidade de enquadramentos que, no mínimo, revelam uma complexidade explícita de se entender tudo o que Teresa é, como definí-la e definir-se ante ao que lhe acontece, nas diferentes interpretações que lhe fazem. O passar do tempo e a evolução da teologia, psicologia e outras ciências modificaram a compreensão psicológica e científica inicial da santa, a ponto de hoje se poder vê-la, com outro olhar. Isso, unido ao fato da razão não ter encontrado respostas para tudo, auxiliou grandes pesquisadores, líderes à frente de posturas científicas, estender o olhar à mística e buscar a Teresa, em seu testemunho de vida e nas suas obras, respostas sobre o sentido e o significado da vida ao humano.

A abordagem psicanalítica de Denis Vasse mostra um sentido peculiar entrevisto no êxtase, de saída de si, o que na espiritualidade chama-se de enlevo, sobre-elevar-se, elevação espiritual do amor transformador do Pai e do Filho, ação do Espírito Santo (amor do Pai que suscitou o Filho) e que se movimenta no amor entre o Filho e o Pai. Assim, em lugar de histeria e psicopatia, Vasse valoriza a mística como algo que transcende o conatural humano e em lugar da crença delirante a crença enlevante. Em Jung, visualiza-se o transcendental, no enraizamento do imaginário, no arquétipo do centro da alma. Imagética junguiana que leva em conta o sagrado, através da imagem contemplada com abertura, acolhimento, receptividade afetiva e conformação com o outro transcendental, divino semelhante à Teresa em seu Castelo Interior. 


\section{MÍSTICA TERESIANA E A OBRA DO CASTELO INTERIOR}

\section{1 \\ Introdução}

Viu-se no Capítulo I, que Teresa de Ávila, foi alguém que se abriu e se entregou inteiramente ao amor e ao serviço de Deus e dos irmãos. Essa dádiva de sua vida mereceu-lhe o reconhecimento da Igreja e da sociedade, de tal maneira que aqui, pode servir-se das palavras de Padre Pedro Poveda ${ }^{555}$ para dizer que: Teresa ficará para sempre lembrada na história e na vida de seu povo, como uma pessoa "eminentemente humana e toda de Deus" 556 . Toda de Deus vive o dia-adia do encontro com Cristo e toda dos irmãos, comunica-lhes inteiramente essa Presença, com sua experiência de vida, de amizade, de fortaleza e de prece aos que desejam deixar-se conduzir por Ele. Assim, em relação à mística que vive, o que Teresa mais especificamente faz na obra do Castelo Interior, como nas demais obras, é motivar e animar o crente ao desafio da fé. Além disso, no Castelo Interior, realiza uma interessante analogia entre o movimento da pessoa em direção à Deus e a qualidade de vida na direção do encontro com irmãos ${ }^{557}$.

À esta dupla dimensão dá-se atenção peculiar no presente capítulo com o objetivo de mostrar detalhadamente a relação entre o divino e o humano em Teresa. Para isso, evidencia-se, num primeiro momento, como se dá a iniciativa de Deus para o encontro com o humano e em seguida, como se manifesta a consequente resposta mediada e estimulada pela necessidade e chamado humano de se ir ao encontro do Senhor e do próximo. O capítulo serve como base ao

555 Em 1911, Padre Poveda, funda a Academia de Oviedo que inspirada na vida e na obra de Teresa se transformará na futura Instituição Teresiana. INSTITUIÇÃ̃O TERESIANA. São Pedro Poveda. Disponível em http://www.institucionteresiana.com/index.php?option=comcontent\&view $=$ article \&id=57\&Itemid=80\&lang=es. Acessado em 27.05.2012, às $13 \mathrm{~h} 40 \mathrm{~min}$.

${ }^{556}$ A expressão "eminentemente humana e toda de Deus", definindo Santa Teresa é de São Pedro Poveda. Cf. FUNDACIÓN NUEVAMÉRICA, CONSEJO DE CULTURA A. L. La radicalidade de una utopia: Pedro Poveda desde América. Argentina: Buenos Aires, 1993. (Cuadernos Nuevamérica - 4).

557 A obra do Castelo Interior e as demais obras de Teresa de Ávila oportunizam em si mesmas chaves de leitura para a interpretação de seus símbolos e significados. Não obstante isso, particularmente essa obra-prima do Castelo Interior vem sendo lida, interpretada e analisada por tantos leitores, através dos séculos, com extensa bibliografia sobre a simbologia presente. Para maiores informações, veja-se a própria bibliografia desta tese. 
último tema da tese e redige, em síntese, a descrição das sete moradas do Castelo Interior feita por Teresa. Na redação destas, opta-se, por conservar as imagens e os significados próprios da obra de Teresa, ainda sem interagir com outros autores e obras psicológicas, com a finalidade de colocar em maior evidência o que lhe é peculiar, específico. No capítulo seguinte, fazem-se as devidas inter-relações.

\section{2}

\section{Relação com Deus e com os irmãos: preâmbulos à mística teresiana}

Graças à ajuda divina e à humana, através delas e por seus feitos, Teresa deixa um grande legado à humanidade inteira: à Igreja, à teologia e às ciências, de um modo geral. Entre as contribuições que deixou, destacou-se, aqui, sua mística, seu testemunho de mulher, suas obras, a reforma do Carmelo, a fundação de 17 carmelos femininos e a instituição do ramo masculino, com seus dois primeiros $\operatorname{conventos}^{558}$. Sua experiência de oração pessoal na busca de maior intimidade com Deus, sua índole empreendedora, sua firmeza e caráter de mestra espiritual, a qualidade das relações interpessoais à luz da presença do Deus-Conosco, tudo é bênção para o percurso dos seus quinhentos anos de história e para trazê-la a um novo cenário teológico-místico na Igreja e na sociedade pós-moderna.

As quatro grandes obras que Teresa de Ávila escreveu, com seus títulos traduzidos para o Português, são ${ }^{559}$ : Livro da Vida (1562, em primeira redação e 1565, em segunda redação); Caminho de Perfeição (1566, em duas redações: Manuscrito do Escorial e de Valladolid, com cópias manuscritas em Madrid, Salamanca e Toledo; Castelo Interior ou Moradas(1577) e Livro das Fundações (Entre 1573 e 1582), pouco antes de sua morte. Outras obras menores, são: Relações Espirituais, Conceitos do Amor de Deus, Exclamações da alma a Deus, Constituições, Modo de Visitar os Conventos, Certame, Resposta a um Desafio Espiritual, além de aproximadamente 150 Cartas, que se conservam e algumas Poesias. Do legado de Teresa, explanado acima, pontua-se aqui, neste capítulo, a

\footnotetext{
${ }^{558}$ Além da reforma do Carmelo, Teresa realiza a fundação de 17 carmelos femininos e dois masculinos. Cf. SCIADINI, P. Teresa d'Avila ... p. 26.

${ }^{559}$ Cf. SANTA TERESA DE JESUS. Obras completas... p. 1698.
} 
sua mística, enquanto íntimo relacionamento de amizade e de amor com Cristo, um dos maiores tesouros que deixa para todos ${ }^{560}$.

\section{2 .1}

\section{Impulso a partir do relacionamento e da amizade de Deus}

Sim, a oração faz, realmente, efeito na pessoa que reza. Mas esse efeito não é o motivo primordial para se rezar. É um subproduto. O motivo primordial da oração é o amor, primeiro o amor de Deus por nós e, então, o despertar de nosso amor por Deus ${ }^{561}$.

Ao mostrar em sua obra que a mesma dinâmica que move alguém à relação com o Senhor é a que a move a pessoa em direção aos seus semelhantes, Teresa dá a entender que a mesma raiz da oração e do encontro com Deus é a que se fará qualidade e intensidade na relação com os irmãos, sobretudo, porque "quanto mais santas, tanto mais afáveis nas conversas com as Irmãs" ${ }^{~ 562 . ~ O u ~ s e j a, ~ q u a n t o ~}$ mais de Deus, tanto mais dos irmãos e das irmãs. Nota-se que esse ensinamento é uma constante nas inúmeras referências das obras teresianas,

Como sinal do amor de Deus: Aqui, só duas coisas nos pede o Senhor: amor à Sua Majestade e ao próximo. Seguindo-as com perfeição nos unimos a Ele [...]. Ao meu ver, o sinal mais certo para verificar se guardamos essas duas coisas é a observância fiel do amor ao próximo. Com efeito, não é possível saber se amamos a Deus (embora haja grandes indícios para entender que $\mathrm{O}$ amamos; já o amor ao próximo pode ser comprovado). E, convencei-vos: quanto mais praticardes este último, tanto mais estareis praticando o amor a Deus ${ }^{563}$.

No exercício permanente da cotidianidade, desde os pequenos detalhes da vida, pode-se observar a veracidade do amor a Deus e ao próximo.

Já que esse ponto tem tal importância para nós, procuremos, irmãs, verificar como caminhamos nesse aspecto, mesmo em coisas miúdas. Não façamos caso de coisas grandiosas, que se apresentam a nós em conjunto na oração e nos persuadem de que faremos e aconteceremos por amor ao próximo e por uma única pessoa que se salve. Porque, se as obras posteriores não estão em concordância com isso, não é de crer que o faremos ${ }^{564}$.

\footnotetext{
${ }^{560}$ A definição clássica de Teresa a respeito da oração; "Para mim oração mental não é outra coisa senão tratar de amizade, estando muitas vezes tratando a sós, com quem sabemos que nos ama". V 8,5 .

${ }^{561}$ BARRY, W. A. Deus e você. A oração como um relacionamento pessoal. São Paulo: Loyola, 1998. p. 76.

${ }^{562} \mathrm{C} 42,7$.

$5635 \mathrm{M} \mathrm{3,} 8$.

$5645 \mathrm{M} \mathrm{3,} 9$.
} 
Como alento à caridade e à virtude, o cristão não pode omitir-se em favor do próximo. Sempre há algo a fazer. Quando forças e recursos humanos se esvaem, parecendo não se ter outra forma de auxílio, enquanto houver vida, através da solidariedade espiritual, ainda se poderá alcançar os irmãos e seguir a serví-los:

Como o Senhor vos traz a tão grande estado, servi a Ele e não vos acovardeis; pois embora sejais religiosas, se não puderdes beneficiar o próximo com obras, especialmente sendo mulheres, com grande determinação e vivos desejos de almas, vossa oração terá força ${ }^{565}$.

Assim, vê-se que o amor de Deus nasce da mesma raiz do amor ao próximo:

É de grande importância estarmos muito atentas a isso. Se guardamos com perfeição o amor ao próximo, temos tudo feito. Pois creio que, sendo má a nossa natureza, só chegaremos a praticar com perfeição esse preceito se o amor ao próximo tiver como raiz o amor a Deus ${ }^{566}$.

E é a excelência de virtude:

Ó Irmãs, como se pode ver claramente que em algumas de vós existe de fato o amor ao próximo, enquanto em outras não chegou ele à mesma perfeição! Se entendêsseis a real importância dessa virtude não teríes outro anseio na vida! ${ }^{567}$

Certamente pela descoberta e empenho de ao elevar-se espiritualmente ser também mais humana, é que Teresa se tornará eminentemente humana e toda de Deus, como afirmava Poveda. Assim, a mesma raiz que leva a pessoa comunicarse com Deus a alimenta em seu constante compromisso de permanecer na amizade com Ele, no exercício do comprometimento dialogante com os irmãos. Esta é a analogia entre a qualidade do relacionamento com Deus e o próximo ${ }^{568}$.

Deste modo, esse exercício de relacionar-se, com Deus, ou com os irmãos, significa transcendência de si. Ora, vive-se, hoje, num tempo no qual se tem profunda necessidade desse diálogo com Deus e de senti-lo presente, o que se revela no expresso desejo da sede humana de intimidade e de relacionamento com Deus. Ao mesmo tempo, também, se tem profunda necessidade da presença e do encontro com os irmãos, expresso em outra sede humana: a de aproximação e de

\footnotetext{
${ }^{565}$ SANTA TERESA DE JESUS. Conceitos do Amor de Deus. In: SANTA TERESA DE JESUS. Obras Completas... (Apartir de agora abreviada por CAM). CAM 2, 29.

${ }_{566}^{5 \mathrm{M} 3,9 .}$

${ }^{567} 5 \mathrm{M} 3,10$.

${ }^{568}$ A esse respeito pode-se ler também: ÁLVAREZ, A. S. Castillo Interior. Camino hacia el encuentro con Dios con Santa Teresa de Jesús. Burgos: Editorial Monte Carmelo, 2001, particularmente p. 58.
} 
relacionamento com os outros. Essa sede pelo encontro é inerente ao ser humano, dado não ter sido feito para estar só, mas para estar em relação ${ }^{569}$.

Sabe-se que, às vezes, o desejo e o impulso para esta aproximação ao outro é consciente, outras vezes, a motivação é inconsciente e a resposta para esse dinamismo interpessoal da vida, de orientar-se, tanto ao transcendente como ao imanente, pode se dar por distintos modos. Contudo, não obstante expressar-se de um jeito, ou outro, é sempre um desejo de transcendência, como refere Victor Frankl, fundador da Logoterapia e psicologia do sentido da vida.

Ser homem significa estar em relação com algo, ou alguém diferente de si, seja isso um significado a realizar, ou outros seres humanos a encontrar. A existência vacila e desmorona se essa qualidade de autotranscêndência não é vivida $^{570}$.

A partir daqui seria possível alguma correlação, questionando e constatando como o movimento em direção a Deus e aos irmãos pode significar autotranscendência, proximidade e como poder avaliar a percepção dos seus aspectos internos de similaridade, positividade, ou negatividade, tanto em relação a um como ao outro. Sería possível também aproximações para se perceber que a inconsciência, ou a inconsistência no viver, que muitas vezes flui e influi na dinâmica emocional e que se não houver clareza de qual processo de fundo, qual o sentido e a direção dos fenômenos, talvez a existência possa deixe, em alguns, a sensação de incompletude e não favoreça a plenitude, a alegria e o aproveitamento que lhe seriam possíveis. Contudo, não cabe aqui questionar a dinâmica sociológica do funcionamento humano em geral, mas a essência da relação, suas características principais e como se integram na pessoa os movimentos da interrelação, sob o prisma de desenvolvimento humano-espiritual na relação com Deus e com os outros, desde uma perspectiva teresiana. Desta forma, poderá se entender melhor que "Deus tem um relacionamento com todas as coisas criadas do universo e que esse relacionamento é total, pois Ele continuamente cria e ampara

\footnotetext{
${ }^{569}$ A bibliografia sobre a necessidade social, do relacionamento e do encontro para o ser humano é extensíssima na antropologia, sociologia, teologia e outras ciências. Sugere-se a consulta da bibliografia da tese e frisa-se aqui, sua capacidade natural: "O homem é um ser social, ou seja, vive em grupos e necessita se relacionar com os seus membros, interagindo com eles. A comunicação faz parte da essência do ser humano e é considerada uma das nossas principais características enquanto espécie". SILVA, L. A. Redação: qualidade na comunicação escrita. 10. ed. Curitiba: Ibpex, 2005. p. 14.; FINKLER, P. Porquê sou psicólogo humanista? Porto Alegre: EDIPUC, 2000. p. 23.

${ }^{570}$ FRANKL, V. Apud FINKLER, P. Porquê sou psicólogo humanista?... p. 32.
} 
a tudo e a todos no universo"571. Por isso, Teresa chega a expressar: "Que podemos fazer por um Deus tão generoso, que morreu por nós, nos criou e nos dá a vida?",572.

Muito embora toda a superficialidade possível no discernimento, da compreensão do propósito da vida e consistência do existir, Deus está aí. Não somente é irreversível na sua determinação de comunicar-se com a pessoa humana e de aperfeiçoá-la como obra-prima de suas mãos, como também deseja prosseguir construindo um futuro com ela, acompanhando-a e abençoando-a em sua trajetória, num relacionamento profundo e existencial. A oração é um meio privilegiado de enveredar-se por esse caminho da comunicação com Deus por uma escolha e olhar consciente, pois.

O relacionamento consciente começa quando decido dar atenção ou olhar para que o outro está fazendo. Depois de ter feito essa opção, então decido se vou responder, ou não. Assim por oração contemplativa nós entendemos a disposição e o desejo de olhar para Deus e prestar atenção ao que ele deseja ser para mim e responder-lhe. Posso aceitá-lo, ou rejeitá-lo do modo que ele quer ser. Em qualquer dos casos terei respondido ${ }^{573}$.

Assim, enquanto resposta da pessoa ao desejo de comunicação do Senhor, pela ação da graça é possível fazer uma escolha consciente pela oração e, por esta via ser introduzido na mística, na esfera da comunicação com Deus.

Ora, o primeiro aspecto na definição de oração de Teresa, justamente, tem a ver com essa consciência e essa mística de contemplação, pois para Teresa: “oração não é outra coisa senão tratar de amizade, estando muitas vezes a sós, com Aquele que sabemos que nos ama" ${ }^{, 574}$. Ou seja, nada mais, nada menos, que um relacionamento. Consciente, vindo de Deus e, ao mesmo tempo, da opção humana, pois: é tratar de amizade, de amor, de companhia, é tratar da relação.

Para melhor compreensão das considerações que a mística teresiana oferece desdobram-se, a partir de agora, estes conceitos: de oração enquanto relacionamento de amizade com Deus, que estabelece com o ser humano uma verdadeira e fecunda re-lação de amizade e de como ela se dá a partir da iniciativa divina e da consequente resposta humana na inter-comunicação. Parte-se aqui de

${ }^{571}$ BARRY, W. A. Deus e você... p. 12.

572 3M 1,8 .

${ }^{573}$ BARRY, W.; CANNOLLY, W. Prática da direção espiritual. 3. ed. São Paulo: Loyola, 1999. p. 46.

${ }^{574} \mathrm{~V} 8,5$. 
um pequeno retrospecto da iniciativa de comunicação do transcendente, de sua generosidade e misericórdia em dialogar com o humano.

Assim, Deus Trindade, o Artífice do Universo ${ }^{575}$, em sua benevolência infinita, cria o orbe ${ }^{576}$. Não tem outra razão para criar a não ser o seu amor e a sua bondade, porque Ele é amor ${ }^{577}$. Entre a obra realizada e seu autor estabelece-se um relacionamento, uma comunicação plena. Deus se comunica com o Universo e o Universo se comunica com Deus. Neste diálogo, o Senhor infunde à criação o seu conhecimento, manifesto na sua liberalidade ${ }^{578}$ na engenhosidade e na maravilha de todo o criado e faz questão de permanecer em todas as coisas ${ }^{579}$. Não obstante, essa criação é apenas "o ponto de partida do Plano de Deus e da história da Salvação, o primeiro dos altos feitos divinos cuja série prossegue ${ }^{\text {"580 }}$, porque Deus não se limita em ter criado o mundo e a expandí-lo em grandiosidade e beleza, mas, na generosidade do seu amor, vislumbra em meio a ele, uma obra ainda mais perfeita ${ }^{581}$, feita à sua imagem e semelhança ${ }^{582}$.

Em virtude disso, o Senhor dá a vida ao ser humano ${ }^{583}$ e, após tê-lo criado, dedica-se a essa vida, mantendo-a e colocando nela todo o seu espírito ${ }^{584}$. Estende sobre a criatura a sua mão ${ }^{585}$ e deposita nela toda a sua fé, toda a sua confiança ${ }^{586}$, pois agora ela é para Deus mais que a pupila de seus olhos. Dá-lhe o domínio de tudo $^{587}$. Como um presente doa-lhe o mundo para que faça nele sua morada, transforme a natureza em sustento e regozijo ${ }^{588}$, o cultivo em desenvolvimento ${ }^{589}$.

$575 \mathrm{O}$ relato mais antigo do Antigo Testamento mostra que, como um artífice, Deus trabalha à maneira humana. Cf. Gn 2,4-25.

${ }^{576}$ Cf. Gn 1.

${ }^{577}$ Cf. 1 Jo,4-8.

${ }^{578} \mathrm{Cf} . \mathrm{V} 10,5$.

${ }^{579}$ Cf. V18,5.

580 LÉON-DUFOUR, X. Criação. In: LÉON-DUFOUR, X. (Dir.). Vocabulário de Teologia Bíblica. 2. ed. Petrópolis: Vozes, 1977. p. 190.

581 “... sua obra é, de saída, perfeita: o homem é criado para ser feliz...”. Ibidem. p. 189.

${ }^{582}$ Cf. Gn 1,26-27.

${ }^{583} \mathrm{Cf}$. V10,5.

${ }^{584}$ É Ele que mantém a vida que deu, quem dá a vida aos homens da terra e espírito àqueles que caminham sobre a terra. Is. 42,5. Cf. McKENZIE, J. L. Dicionário Bíblico. 5. ed. São Paulo: Paulus, 1983. p. 198.

${ }^{585}$ S1 138,10.

${ }^{586}$ A fé que Deus nutre por nós será sempre um convite à vida, uma confiança que deposita em nós. Cf. SUSIN, L.C. Jesus Filho de Deus e Filho de Maria. Ensaio de Cristologia Narrativa". 2. ed. São Paulo: Paulinas, 2002. p. 186.

587 "O homem é feito à imagem de Deus e é em virtude de ser feito à sua imagem que recebe o senhorio sobre o resto da criação”. McKENZIE, J. L. Dicionário Bíblico... p. 197.

${ }^{588}$ Cf. Gn 2.

${ }^{589}$ Criar quer dizer "chamar do nada à existência; portanto criar quer dizer: doar a existência. E se o mundo visível foi criado para o homem é ao homem, portanto, que o mundo é doado". JOÃO 
Dá ao homem e à mulher a sabedoria, que é a capacidade singular de conhecer bem a obra de sua mão e de saboreá-la ${ }^{590}$, compartilhando, assim com ele, de seu próprio saber ${ }^{591}$. No íntimo do coração humano grava seus princípios ${ }^{592}$. E pela via indireta do mandamento entabula o diálogo de amor com sua criatura infundindo-lhe uma orientação de vida, para um fim convergente, que levará a harmoniosa obra de arte à unidade com todo o criado. Compreende-se, pois, que:

A sabedoria criadora de Iahweh é uma inteligência diretriz que mantém a ordem e a harmonia entre tantos elementos divergentes e conflitantes, trata-se do paradoxo de um universo que apesar de todas essas divergências, caminha rumo a um fim que lhe foi estabelecido por Deus ${ }^{593}$.

Deste modo, mesmo criada com total capacidade para dialogar com o transcendente, a criatura humana tem a liberdade para escolher a Deus e a relação amistosa com Ele, ou para rejeitá-1o ${ }^{594}$. E quando, por sua livre opção, voltou às costas para Deus, quebrando a sua amizade com Ele, ainda assim, o Senhor ainda persistiu em seu amor, enviando seu Filho para que todo aquele que acolhe e crê em Jesus, receba a graça de ser, em Cristo, filho dileto de Deus ${ }^{595}$. Pois “em Cristo, Deus nos escolheu, antes da fundação do mundo, para sermos santos e irrepreensíveis diante d'Ele no amor e nos predestinou a sermos seus filhos adotivos" ${ }^{, 596}$. Nesta nova e eterna Aliança com Jesus Cristo, o Filho amado de Deus, a pessoa fica, novamente, em amizade com o divino. E, nesta peculiar amizade, o Pai, na ação de seu Espírito, envolve em Cristo o ser humano, estabelecendo com ele uma relação amorosa como demonstra a doutrina teresiana, no segundo romance de São João da Cruz: “A Comunicação das Três Pessoas":

E naquele amor imenso que de ambos procedia, palavras de grande gozo, O Pai ao Filho dizia, de tão profundo deleite que ninguém as entendia; Somente o Filho as gozava, pois a Ele pertencia. Mas naquilo que se entende, desta maneira dizia:_Nada me contenta, Filho, fora da tua companhia. E se algo me contenta, em ti mesmo o quereria. $\mathrm{O}$ que a ti mais se parece, a mim mais

PAULO II. Carta Encíclica Dominum et vivificantem. Sobre o Espírito Santo na vida da Igreja e do mundo. n. 34. São Paulo: Loyola, 1986. p. 53.

${ }^{590} \mathrm{Cf}$. Is 1,19 .

591 "Na literatura sapiencial, a sabedoria divina aparece com ele na obra da criação". Pr 8,22-31;

McKENZIE, J.L. Dicionário Bíblico... p. 197.

${ }^{592}$ Cf. Jr 31,31-33.

${ }^{593}$ LÉON-DUFOUR, X. Criação. In: LÉON-DUFOUR (Dir). Vocabulário... p. 198.

594 "A liberdade é o poder, baseado na razão e na vontade, de agir ou não agir, de fazer isto ou aquilo, portanto de praticar atos deliberados. Pelo livre-arbítrio, cada qual dispõe sobre si mesmo. CATECISMO DA IGREJA CATÓLICA Petrópolis/São Paulo: Vozes/Loyola, 1993. n 1731; $1733 ; 1734 ; 1744 ; 1745$. Posteriormente citado por (CEC).

${ }^{595}$ Cf. Jo 1,12 .

${ }^{596}$ Ef $1,4-5$. 
satisfazia; E o que em nada te assemelha em mim nada encontraria. Só de ti eu me agradei, ó vida da vida minha! És a luz da minha luz! És minha sabedoria; Figura da minha substância em quem bem me comprazia. Ao que a ti te amar, meu Filho, a mim mesmo me daria. E o amor que eu em ti tenho, nele mesmo eu o poria, por razão de ter amado aquele a quem tanto queria ${ }^{597}$.

Vê-se, assim que o Pai toca de forma indelével o coração humano, com o selo do seu amor que é eterno, para que toda pessoa permaneça com Ele em profunda e íntima comunhão ${ }^{598}$, e

Deste modo, Deus prova $(\mathrm{Rm} 5,8)$ que sua atitude definitiva para com o ser humano é a de 'amar o mundo' (Jo 3,16) e que, por esse gesto supremo e irrevogável, ele nos ama com o próprio amor com que ama a seu Filho único e nos torna capazes de o amarmos com o amor que dedica a seu Filho, Ele nos dá o dom do amor que une o Pai e o Filho e que é o seu Espírito Santo ${ }^{599}$.

Da maneira, acima demonstrada, a oração pode ser compreendida como relacionamento, como iniciativa e proposta de Deus ao humano para um diálogo com Ele, somada à procedente capacidade de resposta da pessoa à essa comunicação de amor. Com isso, afirma-se, em primeiro lugar, que a tendência humana mais original é a da liberdade dos filhos e das filhas de Deus para aceitarem, ou não, a relação com o divino. E, no caso da aceitação, despertar-se para a contemplação da maravilhosa obra da criação de Deus, naturalmente identificando e distinguindo nela o seu amor, ao assimilá-lo e vivê-lo profundamente na comunhão e na relação com todo o universo.

\section{2 .2}

\section{Impulso como resposta humana à iniciativa de amor de Deus}

Viu-se acima que Deus tem a iniciativa e a proposta para o humano. Da parte deste, espera-se a resposta ao convite recebido para o reconhecimento e acolhimento de Deus, como Criador e Senhor de sua vida. Mas o desígnio sobrenatural do ser humano não parte só desta realidade antropológica de ser aberto ao outro, ao absoluto, ao transcendente, uma vez que, ao perceber e ao glorificar a Deus, através de suas obras e de sua mensagem é convidado a aceitar a salvação oferecida pelo Senhor em sua aliança definitiva e, através dela,

597 SÃO JOÃO DA CRUZ. Poesias. In: Obras Completas. 6. ed. Petrópolis: Vozes, 2000. Romance 2. p. 46-47.

${ }^{598}$ Cf. CEC 1274; 1280.

${ }^{599}$ LÉON-DUFOUR, X. Mundo. In: LÉON-DUFOUR, X. (Dir.). Vocabulário... p. 228-229. 
obsequiado a resgatar sua originalidade, realizando em Cristo e no seu Espírito, novamente a união com o Criador. Deste modo, o desejo de Deus, inscrito no coração humano é que “criado por Deus e para Deus, Deus não cessa de atraí-lo a si, porque somente em Deus a pessoa há de encontrar a verdade e a felicidade que não cessa de procurar" ${ }^{\circ 00}$.

O desenvolvimento dessa unidade desejada por Deus e humanamente tão aspirada, terá sentido na colaboração humana. Da parte de Jesus Cristo, tendo Ele em si, a plenitude do Espírito, comunica-a a todos, renovando-os interiormente e fazendo-os uma nova criatura ${ }^{601}$. Por parte da pessoa, ao consentir neste relacionamento com Cristo, o rosto humano de Deus, acolhe de forma decisiva e consciente a revelação, a comunicação do Senhor e, na relação com todo o gênero criado, é habilitado por Deus, a ser entre toda a obra criada, a expressão mais evidente e encantadora do seu amor: "o louvor vivo de sua glória"602.

Em suma, o Senhor chamou o homem e a mulher à existência, abençoou-os e deu-lhes a graça de receberem a revelação de Deus, sua Auto-Comunicação, o próprio dom de Si mesmo de Deus. Deste modo, fortalece a relação com o humano, em um diálogo constante e numa comunicação fecunda. Acolher a graça que Deus concede e sua salvação é a abertura do coração humano, na liberdade de seu ser, para a relação de amizade com Ele. Ao aspirar seu próprio desenvolvimento e ao efetivar a comunicação com o transcendente, neste envolvente relacionamento com o Senhor, a pessoa orienta para Ele sua existência, atualiza a filial co-participação na comunhão trinitária e move-se na ação do Espírito Santo. Une-se intimamente a Cristo, a quem, através do coração humano, ora e entrega sua vida ao Pai, elevando-a em nome de todo o gênero ${ }^{603}$.

A partir desta retrospectiva do encontro do divino com o humano poderá perceber-se de modo mais claro que a mensagem central de Teresa, em seu desejo de levar as pessoas ao encontro com Deus, através da oração, do diálogo com Ele, pela via do castelo interior de cada pessoa, não tem outro intento senão favorecer

${ }^{600}$ SANTO AGOSTINHO. Apud CEI- Itaici. Rabi onde moras: Roteiro para uma oração e vida ao longo do noviciado. 3. ed. São Paulo: Loyola, 1996. p. 68-69.

${ }^{601}$ Cf. Mc 10 1,10; Lc 4,1.

${ }^{602}$ Ef $1,5-6$.

${ }^{603}$ A oração de Jesus possibilita que a oração conduza a pessoa à intimidade com o Pai, ao fundir sua oração com a dele possibilita, igualmente, que a relação com Deus seja nova e filial. Cf. RODRIGUEZ, A. A.; CANALS CASAS, J. Oração de Jesus. In: RODRIGUEZ, A. A.; CANALS CASAS, J. Dicionário Teológico da Vida Consagrada. São Paulo: Paulus, 1994. p. 761. 
caminhos para o resgate da originalidade dessa comunicação primitiva entre Criador e criatura, tendo como Modelo de vida a própria encarnação de Cristo.

\section{3}

\section{A Obra de Teresa que se reescreve na atualidade}

Viu-se, acima, que a sede do encontro entre o divino e o humano é iniciativa de Deus e está no âmago do coração de cada um. Na simplicidade e dinâmica do existir, ao se estar aberto e sensível ao movimento da graça, poderá se perceber a importância do amor e da necessidade da escuta e do diálogo com esta Presença. Compreende-se, pois, que a íntima e fecunda relação de amizade explicitada no ponto anterior, mostra-se, agora, aqui, como o núcleo da mensagem teresiana.

Assim, abaixo se dá a entender como Teresa compreende essa relação na obra do Castelo Interior e como, na sua percepção se desenvolve a comunicação espiritual entre Deus e o humano.

A obra do Castelo Interior Teresa iniciou no dia dois de junho de 1577, festa da Santíssima Trindade, por pedido do Padre Gracián que lhe afirma que nas coisas de oração "quem tem experiência, consegue explicá-la melhor do que aquele que só tem ciência, ainda que falasse sobre esse assunto muito apropriadamente" ${ }^{604}$. Assim, tratando sobre assuntos de oração Teresa dizia ao Padre Gracián: “Óh! Como esse ponto já está bem escrito no livro de minha Vida, que está na Inquisição". E Gracián, responde: “Já que não podemos tê-lo[...], escreva outro livro e diga a doutrina comum, sem nomear a quem sucedeu o que ali disser". Não obstante toda insistência, Teresa lhe diz:

Para que querem que eu escreva? Escrevam os letrados, que estudaram. Sou uma tonta e não saberei o que falar: trocarei uma palavra por outra e com isso causarei dano. Já se escreveram muitos livros sobre coisas de oração. Pelo amor de Deus, deixem-me fiar em minha roca e seguir meu coro e meus ofícios de religião, como as outras irmãs. Não sirvo para escrever... ${ }^{605}$.

Gracián e Velasquez vencem a resistência da Madre, que redige o livro às suas Irmãs. Estas, pelo carinho que lhe têm, acolhem com amor a cada página de

\footnotetext{
${ }^{604}$ ALVAREZ, T. Introdução ao Castelo Interior ou Moradas. In: SANTA TERESA DE JESUS Obras Completas... p. 435.

${ }^{605}$ Ibidem. p. 434.
} 
Teresa $^{606}$. A obra é escrita apressadamente. Não obstante toda rapidez e as mais difíceis circunstâncias na ocasião, Teresa deixa impressa no manuscrito grande serenidade. Aos vinte e nove de novembro de 1577, em São José de Ávila, conclui o Castelo Interior, considerado, o livro da sua maturidade humana, espiritual e magisterial $^{607}$. Tão bem escrito está que, até mesmo a seus próprios olhos, a santa o denomina de: “jóia”! É o seu livro predileto! ${ }^{608}$.

As Moradas do Castelo Interior é o título original da obra. "Não encontrando outra coisa com que comparar a grande formosura de uma alma e a sua grande capacidade ${ }^{609}$,, serve-se da imagem literária de um castelo, característica de seu tempo e de sua cidade natal, para representar a realidade do mundo interior em diálogo com Deus ${ }^{610}$.

Falo de considerar a nossa alma como um castelo todo de diamante, ou de um cristal muito claro, onde há muitos aposentos, tal como no céu há muitas moradas. A bem da verdade, Irmãs, não é outra coisa a alma do justo senão um paraíso, onde Ele disse ter Suas delícias. Pois não achais que assim será o aposento onde um Rei tão poderoso, tão sábio, tão puro, tão pleno de todos os bens se deleita ${ }^{611}$ ?

A obra do Castelo Interior é valiosa a muitas pessoas e grupos. Poderia ter se perdido na história, ao longo destes quinhentos anos, mas não. Continua sendo revisitada por muitos, inclusive em mais esta tese e segue, como chama que não se apaga, sempre viva, que não se extingue, sempre iluminando, com novos fachos de luz, ora a um tema, ora a outros, como seus demais escritos. No Castelo Interior vê-se que buscar a Cristo como Amigo, aspirar sua orientação e desejar caminhar com Ele, são respostas generosas à gratuidade de seu chamado e amor.

\subsection{1}

\section{Influência literária presente na redação do Castelo}

No item 5.3.2 são expostas as imagens, a descrição das moradas e os significados de símbolos presentes no Castelo Interior de Teresa. Para preparar este ítem, no 5.3.1, apresentam-se possíveis relações e características do tempo de

\footnotetext{
${ }^{606}$ Ibidem. p. 434-435.

${ }^{607}$ Cf. ÁLVAREZ, A. S. Castillo Interior... p. 8.

608 “Aquela jóia”. SANTA TERESA DE JESUS. Cartas. In: SANTA TERESA DE JESUS. Obras Completas... (A partir de agora abreviada por Cta.). Cta 212,10 e Cta 213,12.

${ }^{609} 1 \mathrm{M} 1,1$.

${ }^{610}$ Cf. ÁLVAREZ, A. S. Castillo Interior... p. 25.

$6111 \mathrm{M} 1,1$.
} 
Teresa, as quais são analisadas como elementos implícitos do imaginário da monja, que talvez a influenciaram na redação da obra. Não se objetiva aqui esgotar possibilidades de influência na construção da obra, mas antes compreender que a pessoa é fruto de seu tempo e também um ser social que se constrói, se forma e se constitui, através das relações que estabelece ao longo da vida. Por isso, elencam-se, abaixo, influências possíveis à Teresa, as quais integrou como vivência própria e que, agora, prestam-se a uma leitura específica: das personagens e situações de seu tempo. Procura-se situar o leitor na realidade concreta da monja e na intensidade dos elementos que interagiu, sem fixar-se em apenas uma fonte. As influências que foram consideradas relevantes para essa pesquisa, foram, sobretudo: as obras que Teresa leu; sua região, seu tempo de existência; as amizades e personalidades cultas com quem se relacionou e ainda, os símbolos da literatura europeia medieval e da literatura mística muçulmana.

a) As obras que Teresa leu. Sabe-se pelos próprios escritos teresianos que a exemplo de sua mãe os romances de Cavalaria foram leituras constantes em sua infância e adolescência ${ }^{612}$. Tão apaixonada foi Teresa por essa literatura que chegou a escrever, um romance neste estilo, "Teresa de Ahumada sentiu vocação literária desde muito cedo. Por volta dos 14 anos, escreveu um romance de cavalaria para diversão de seus amigos e amigas ${ } 613$. Ora, a literatura cavaleiresca é um dos símbolos medievais mais fortes. O herói medieval combate por seu rei e pela pátria. "Na mundividência do cavaleiro medieval, a coragem em combater era um dos valores essenciais a preservar, pois também dela dependia a honra da linhagem"614. Assim, na redação do Castelo de Teresa, essa literatura de sua infância e adolescência cheia de garra, de lutas, de conquistas, volta a fazer parte em sua nova fase de escritora.

Para Padre Gracián, orientador espiritual e grande amigo de Teresa, ficava muito clara a influência das obras juvenis lidas e escrita pela mística. Quando ele procurava consolo na monja para enfrentar as inúmeras perseguições que lhe advinham, ficava sempre surpreso com seu renovado idealismo e coragem como,

\footnotetext{
${ }^{612} \mathrm{Cf} . \mathrm{V} 2,1$.

${ }^{613}$ ALVAREZ, T. Introdução às Obras completas... p. 11.

${ }^{614}$ PEREIRA, A. S. O herói guerreiro cristão: fé coragem e território. In: A historiografia Religiosa Medieval hoje: temas e problemas. Lusitania Sacra. Revista do Centro de Estudos de Historia Religiosa Universidade Católica Portuguesa. 2. Série. Tomo XIII-XIV. Lisboa: Sersilito Empresa Gráfica, 1998. p. 324.
} 
na passagem abaixo, quando Gracián contava à Teresa que suas monjas também estavam sendo acusadas diante da Inquisição. Ela ria muito e dizia: "Oxalá, Padre, nos queimassem a todas por Cristo! Mas não tenha medo que em coisa de fé, pela bondade de Deus, falte alguma de nós! Antes morrer mil mortes ${ }^{615}$ !

Para Tomás Alvarez, o objetivo da autora em escrever o Livro do Castelo Interior era, sobretudo, a possibilidade de voltar à experiência espiritual de uma forma ainda mais completa do que no Livro da Vida. No Castelo Interior, já era possível a Teresa debruçar-se sobre o assunto, de forma diferente, mais madura, não mais constituindo unicamente um relato autobiográfico, como no Livro da Vida, mas somando aí sua experiência mística a um plano doutrinal, sendo possível a Teresa unir duas linhas temáticas: a doutrinal e a autobiográfica ${ }^{616}$.

Relacionado às leituras de cavalaria, outro conceito trabalhado por Alison Weber é o de cavalaria espiritual. $\mathrm{O}$ autor refere, que nas primeiras três moradas do livro, o peregrino é retratado como miles crhisti e a maior parte das batalhas se encontra nessas primeiras moradas ${ }^{617}$. Segundo o autor, a partir das quartas moradas Teresa deixa a simbologia de soldado e adota a imagem do peregrino que se transforma em Sponsa Christi ${ }^{618}$. Então, já não mais soldado, mas esposa ${ }^{619}$.

Para Ballester, a simbologia guerreira de Teresa está presente em outros livros de cavalaria da época. Influenciaram a monja e a motivaram auxiliando-a a coordenar "suas leituras sérias e transcendentes, com a agilidade e o frescor das imaginativas e líricas que devorou, criando um estilo próprio no qual se encadeiam a solidez no conceito e a elegância da narrativa" ${ }^{2020}$. Assim, percebe-se que a influência das leituras dos livros de cavalaria pode ter sido uma das grandes alavancas motivadoras de seu empreendedorismo e idealismo em seus escritos.

Além das leituras cavaleirescas, crê-se que as obras espirituais que Teresa leu a influenciaram de igual forma: a Subida del Monte Sión, de Bernardino de

\footnotetext{
${ }^{615}$ STEGGINK, O; EFREN DE L.M.D. Tiempo y vida de Santa Teresa.... p. 492.

${ }^{616}$ Cf. ALVAREZ, T. Guia al Interior del Castillo: Lectura espiritual de las Moradas. Burgos: Editorial Monte Carmelo, 2000. p. 10; CAMINERO, J. Dialéctica de la experiencia y la erudición en el proceso místico de Santa Teresa. Letras de Deusto, Bilbao, vol. 12, n. 24, jul/dez. 1982. p.107,

617 "Miles Christi" = Soldado de Cristo (latim). Aquele(a) que milita e batalha por Cristo.

618 "Sponsa Christi"= Esposa de Cristo (latim). Aquele(a) que se une inteiramente a Cristo.

${ }^{619}$ SANTOS, L.L. Fémina Inquieta y Andariega... p 108.

${ }^{620}$ BALLESTER. Introducción a Santa Teresa de Jesús. Apud SANTOS, L.L. Fémina Inquieta y Andariega... p. 36.
} 
Laredo $^{621}$, o Tercer abecedário espiritual de Francisco de Osuna, nos quais também se pode ver similaridades. Para Bernardino de Laredo, por exemplo, a semelhança está no fato do autor expressar que alma deve ser feita como um cristal, clara e preciosa. Para Francisco de Osuna a comparação do castelo como fortaleza é muito similar. $\mathrm{O}$ autor também serve-se de outros símbolos análogos para explicar a vida espiritual e inclusive, a própria Teresa reconheceu que tirou dele a sua doutrina de recolhimento ${ }^{622}$.

Segundo Luciana Santos, embora não se tenha registro nas obras da santa da literatura utilizada por ela, nas entrelinhas há possibilidade de visualizar romances que talvez Teresa tivesse lido. Como, por exemplo, a "Gran Conquista de Ultramar"623, de "Las Sergas de Splandian" ${ }^{624 "}$ e "Amadis de Gaula" que até mesmo podem ter sido seus favoritos ${ }^{625}$. Isso se demonstra na observação de que

Entre os inúmeros castelos que aparecem em Amadis de Gaula o Castelo de Miraflores é o que mais se assemelha com a descrição teresiana. Na obra ele aparece como "la más sabrosa morada [...] que em toda aquella tierra había", rodeado por muitas árvores, flores e frutos. Dentre dele, había salas y camaras. Este castelo por ser "tan hermoso" tinha sido um presente do Rei à sua filha Oriana, que mandou fazer em frente à porta do castelo "un monestério de monjas", porta do castelo que para Teresa era a própria oração ${ }^{626}$.

Contudo, ainda há algo que pode aproximar mais as duas construções, são:

as ações que acontecem dentro dele e, mais ainda, as características do personagem principal - o cavaleiro Amadis em "Amadis de Gaula" e o cristão no castelo de Teresa. O objetivo da aventura de ambos é o amor. Os dois personagens são um misto de cortesão e de guerreiro, seguindo, desta forma, o modelo de Lancelote cavaleiro-galante. Em "Amadis" o cavaleiro luta até o fim, passando por todos os obstáculos possíveis pelo amor de Oriana, sua grande amada. Em "Moradas" o cristão deve batalhar contra os inimigos (as

\footnotetext{
${ }^{621}$ Bernardino de Laredo, conhecedor da mística alemã, instrumentaliza o conceito de sublimidade inclusive como ação verbal e particularmente a vida contemplativa da alma na obra Subida ao Monte Sión. Cf. HARO, P. A. La sublimidade y lo sublime. Madrid: editorial Verbum, S.L., 2006. p. $56-57$.

${ }_{622}$ Cf. V 4,7 .

${ }^{623}$ GAYANGOS, P. La gran conquista de Ultramar. Madrid: M. Rivadeneyra Impressor, 1958. Fala das grandes conquistas e feitos dos peregrinos na História da Palestina e Jerusalém, com fabulosas tradições piedosas e cavalheirescas.

${ }^{624}$ Esta obra é considerada como a continuação da tragicomédia de Amadis. Saída em versão espanhola, muito vulgarizada em 1519 e em menos de um século traduzida em italiano, francês, inglês e alemão. Cf. BRAGA, T. Historia do theatro portuguez. Porto: Editora Imprensa Portuguesa, 1870. p. 156-157.

${ }^{625}$ Sobre esta obra: "Lope de Vega atribuye, el libro de Amadis a una dama portuguesa. El abate Liampilles disse que ele primer romance español titulado Amadis de Gaula, fue compuesto en el siglo XIV, por ele portugues Vasco Lobeira; añadiendo que apenas se publicó, fue creido superior a cuantos habian salido hasta entonces, y a cuantos se escribieron hasta el Quijote". BASTÚS, V. J. Suplemento al Diccionario histórico enciclopédico. Barcelona, 1833. p. 70-71.

${ }^{626}$ SANTOS, L. L. Fémina Inquieta y Andariega... p. 111.
} 
coisas mundanas e o demônio), para chegar à sala principal do castelo, na qual reside o Amado e onde ocorre o matrimônio espiritual... ${ }^{627}$.

Santos acredita que Teresa escreveu uma espécie de livro de cavalarias a lo divino, e o objetivo seria de auxiliar seus leitores na busca de maior conhecimento interior e melhor relacionamento com a natureza de Deus. Através desta cavalaria espiritual, seriam animados a vencer, e o amor seria-lhes o dinamismo heroico, uma vez que movimenta tanto o cristão como o cavaleiro para amar e agir ${ }^{628}$.

b) Sua região e seu tempo de existência. Para Leon Bonaventure a fonte principal de influência para Teresa teriam sido as muralhas e as torres de Ávila, dado que Castilla e a Espanha de seu tempo eram semeadas de magníficos castelos e esplendidas moradas. Em cada castelo, vivia-se uma vida autônoma ${ }^{629}$. Já para Lopez-Baraltz considerar que Teresa fez a comparação de seu Castelo apenas a partir das muralhas de Ávila é uma teoria superficial. Para a autora a literatura islâmica seria a maior responsável das influências à Teresa, dado poder se ver o símbolo dos sete castelos concêntricos na alma e, também, no Islam. Assim, Lopez-Baraltz o provável seria Teresa ter lido los Nawadir, ou Nüri e os sete séculos de diferença entre essa literatura e Teresa podiam ser a representação dessa sequência literária nas sete moradas ${ }^{630}$.

Não obstante as influências admissíveis é importante dizer, como Cristovão Cuebas García, que os livros de Cavalaria e o romanceiro espanhol, são, na realidade, chaves explicativas para o símbolo teresiano ${ }^{631}$. Para este autor:

Se o edifício teresiano é esférico, se nele se encontram traços tão suntuosos como muitos dos descritos, se os adjetivos que se aplicam gravitam mais pela área semântica da beleza, resplendor, amenidade, etc., que pelos da força, parece claro que estamos mais diante de um castelo-palácio que diante de uma fortaleza[...], o motivo fundamental radica(se) em que o edifício teresiano é, sobretudo, vivenda de apaixonados, mansão de amor ${ }^{632}$.

c) Amizades e personalidades cultas com quem se relacionou. Teresa vivia rodeada de pessoas. Aproximava-se de pessoas cultas, de sacerdotes intelectuais,

${ }^{627}$ Idem.

${ }^{628}$ A nova espiritualidade deste tempo se identificava com a cavalaria, por isso cavalaria espiritual. Representantes dessa corrente: Bernardo de Claraval, Inácio de Loyola e Ordem dos Templários. Cf. PEREIRA, A. S. O herói guerreiro cristão... p. 146-147.

${ }^{629}$ Cf. BONAVENTURE, L. Contribuição para uma psicologia cristã... p. 36.

${ }^{630}$ Cf. LOPEZ-BARALT, L. Huellas del Islam en la literatura espanola. Madrid: Hiperión, 1985. p. 228.

${ }^{631}$ GARCÍA. Apud SANTOS, L.L. Fémina Inquieta... p. 109.

${ }^{632}$ Ibidem. p. 110. 
pessoas da alta sociedade e dos simples. Na época de Teresa não havia somente a crença de que o sofrimento humano seria recompensado pela felicidade celeste e além-túmulo, mas também a credibilidade do povo e das grandes instituições sociais e religiosas, de que, as mulheres deviam sujeitar-se aos homens por serem eles os representantes e porta-vozes de Deus ${ }^{633}$. Assim aos homens daquele tempo, era lícito tanto o reconhecimento quanto a valorização e a censura. Deste modo, considerava-se ordinário que mulheres que, de certa forma se entendessem colaboradoras sociais, deveriam aproximar-se de homens influentes em repartições públicas e/ou de intelectuais para, legitimarem-se a si mesmas e a seus feitos. Contudo, isso não aliviava o controle, nem a censura que era sempre mais enérgica para o feminino daquele tempo. Talvez, exatamente, por isso fosse importante à Teresa assegurar-se da teoria dos sacerdotes (teologia), quanto das altas personalidades de quem se aproximava, dado sua grande atividade, os fenômenos místicos que lhe acompanhavam, suas obras escritas e a fundação dos conventos de homens e de mulheres descalças que criou. Ao lado destas considerações ressalta-se aqui o papel de diretor espiritual também muito respeitado no contexto de Teresa, a ponto da monja afirmar que se cresce mais espiritualmente quando a pessoa se entrega à obediência de um orientador espiritual, que represente ao próprio Cristo ${ }^{634}$. Assim, por estas vias, por estes amigos e sacerdotes, Teresa ia recebendo instruções, tanto individualmente quanto nas homilias, obras, que obviamente a influenciavam na redação de seus escritos.

e. Símbolos da literatura europeia medieval e de outras literaturas místicas. O castelo era considerado um símbolo constante na literatura europeia medieval e significava "refúgio, ou um santuário nas montanhas", como também "símbolo de um passado nobre"635. Segundo Maria Clara de Almeida Lucas, para os visionários do final da Idade Média essa recorrência não somente era comum, mas costumeiramente, através dela passava-se a representação de um outro mundo, a partir da figura do castelo no seu centro, de modo que:

O castelo que se estabelece no centro do mundo paradisíaco não é aquele castelo sobranceiro ao burgo que o homem medieval tão bem conhece, centro

${ }^{633}$ Cf. KLEIN. Apud BARREIRA, I. A. A enfermeira-Ananéri no "País do Futuro": a aventura da luta contra a tuberculose. (Tese de Doutoramento). Rio de Janeiro: UFRJ, Escola de Enfermagem Anna Nery, 1992. p. 17.

${ }^{634}$ Cf. $3 \mathrm{M} 2,12$.

${ }^{635}$ SÁ. D. S. de. Gótico Tropical: o sublime e o demoníaco em O guarani. Salvador: EDUFBA, 2010. p. 69. 
do poder temporal e religioso, este só exteriormente se lhe assemelha, porque ao aproximar-se o leitor verá que as portas de ouro maciço, as ameias de cristal e as pedras preciosas recobrem(-lhe) os pavimentos ${ }^{636}$.

Assim, o castelo é um simbolo de proteção, no qual a pessoa abriga-se, aconchega-se. Há nele algo de maravilhoso que o herói busca ansiosamente e ao qual dá sua vida para alcançar. Tem como meta chegar ao núcleo mais profundo, independente das dificuldades a enfrentar e as dificuldades de acesso, pois é lá onde se encontram os bens mais deleitosos. Nisso o herói coloca todo seu fôlego em subir e adentrar ao castelo com garra, decisão e presteza. Não importa de caminhar muito, sofrer, subir elevações escarpadas, ou lutar contra florestas. Não se importa de combater monstros temíveis no intuito de defender o castelo da vista do intruso e alcançar a meta ${ }^{637}$.

Entretanto dá para perceber uma nítida diferença entre Teresa e os visionários da época: o castelo para os visionários representava apenas a visão do Reino de Deus, do Reino Celestial, ali se chegava e ali se concluía tudo, enquanto que para Teresa o castelo é o núcleo da própria alma, que no Paraíso se encontra com Deus e dali se tira as forças e se reabastece para voltar a lutar no mundo presente $^{638}$.

Para finalizar, através deste ítem pôde se perceber que Teresa, como filha de seu tempo, deixou-se influenciar por símbolos enraizados na vida de seu povo, na sua época e nas suas relações. Não obstante todas as possíveis influências, a que se crê que mais intensamente subjaz como pano de fundo do Castelo Interior é a influência da leitura cavaleiresca. Dado sua redação trazer inúmeras lembranças e analogias à cavalaria espiritual, às lutas, ao esforço de superação, levando o cristão a apropriar-se desta dinâmica para processá-la em seu desenvolvimento humano-espiritual.

\section{3 .2}

\section{Castelo Interior e seus símbolos (ao redor e interior)}

Neste ítem mostram-se os símbolos usados no Castelo Interior de Teresa a fim de esclarecer o olhar e o manejo da santa para expressar o relacionamento

${ }^{636}$ LUCAS, M.C.A. A Literatura Visionária na Idade Média Portuguesa. Lisboa: Biblioteca Breve, ICLP (Instituto de Cultura e Língua Portuguesa), 1986. p. 13.

${ }^{637}$ Cf. LUCAS, M.C.A. A Literatura Visionária... p. 11.

${ }^{638}$ SANTOS, L.L. Fémina Inquieta... p. 106. 
com Deus e com as pessoas. De modo que, neste castelo, encontram-se muitas realidades simbólicas:

O castelo - é a alma. Tem muitas moradas: umas no alto, outras em baixo, outras aos $\operatorname{lados}^{639}$. Não se encontram enfileiradas. Dispõem-se na forma circular, como um palmito ${ }^{640}$. No centro do castelo mora e deleita-se um rei extremamente poderoso, sábio, puro, pleno de todos os bens. A morada principal onde esse rei se encontra é um preciosíssimo lugar, um paraíso de grandes formosuras e de grandes delícias ${ }^{641}$. Reflete-se nele uma luz imensa, porque aí se encontra o próprio sol, que é Deus. A luz que se concentra aí, em toda a sua plenitude e resplendor é a mesma que deixará claro, desde o interior, o restante das outras moradas do castelo e que dará calor às obras da pessoa ${ }^{642}$ iluminando suas potências ${ }^{643}$. Bem no centro da morada principal é onde se "passam as coisas mais secretas entre Deus e a alma"644. Não é necessário ter passado pelos aposentos anteriores para a pessoa encontrar-se em uma morada mais adiantada ${ }^{645}$.

A volta do castelo - É a facção mais exterior, a parte que está fora do muro do palácio, onde se encontram os que procuram o aprisionamento do Castelo ${ }^{646}$.

A ronda do castelo - São os que o guardam. Estes fazem pouco caso de entrar. Não têm interesse em saber o que há dentro e, tampouco, Quem está ali ${ }^{647}$.

As moradas, ou aposentos - São simbolicamente sete, mas "não são poucas, mas muitas, um milhão"648.

O palácio, a câmara e o aposento do céu - São o mais íntimo da interioridade humana, "um céu na Terra"649, para aqueles que se contentam em agradar somente a Deus ${ }^{650}$. É o lugar onde mora o Rei, de onde sai a luz e o silvo do pastor. Deus aí está, para que a alma se faça com Ele uma só coisa ${ }^{651}$. Entrar neste espaço é algo semelhante ao que acontece na sociedade, quando alguém vai

${ }^{639}$ Cf. $1 \mathrm{M} 1,3$

${ }^{640} \mathrm{Cf} .1 \mathrm{M} 2,8$.

${ }^{641}$ Cf. 1M1,1-5.

${ }^{642}$ Cf. 1M2,1-5.

${ }^{643}$ Cf. $7 \mathrm{M} 2,6$.

${ }^{644} \mathrm{MM} 1,2$.

${ }^{645}$ Cf. 4M1, 2

${ }^{646}$ Cf. ÁLVAREZ, A. S. Castillo Interior... p. 31.

${ }^{647}$ Cf. 1M1,5.

${ }^{648} 1 \mathrm{M} 2,8$

${ }^{649} 5 \mathrm{M} 1,2$.

${ }^{650}$ Cf. C13,7.

${ }^{651}$ Cf. 6M4,8. 
falar com o governador, com o presidente, ou outra autoridade. Ter essa condição significa ter demonstrado capacidade de se comunicar com alguém respeitável e ter habilidade para sustentar o diálogo. Com nossas forças pouco se pode contar, precisa-se de maior santidade para chegar lá. Por isso, para entrar ali é preciso muita humildade e intimidade com o Rei, o que se dá ao longo de um processo ${ }^{652}$.

Todavia, que não se esqueça: aqui na Terra, ainda que o rei tenha numerosos vassalos, nem todos têm acesso à câmara real[...]. Olhai os santos que tiveram acesso à câmara do Rei e vereis a diferença que há entre eles e nós. Não peçais aquilo que não mereceis; tendo ofendido a Deus, nem nos devia vir à mente a idéia de merecer algum dia a entrada nesse aposento real, por maiores que sejam os nossos serviços ${ }^{653}$.

O Sol - É Deus. Desde o centro, dá resplendor e formosura a todas as peças do castelo e calor (valor) às obras humanas. No pecado, as obras boas ficam sem a sua luz, sem nenhum valor ${ }^{654}$.

O silvo do pastor - É o que faz com que as ovelhas aproximem-se de Cristo e não andem perdidas no exterior de si mesmas, mas encontrem a única morada que realmente vale a pena encontrar ${ }^{655}$.

A água, ou a árvore da vida - É donde emerge a graça de Deus. É o canal, por assim dizer, entre Deus (Sol) e a alma humana. A fonte, ou sua raiz, está em Deus. (Quando a pessoa peca fica muito diferente do projeto de filiação divina, que Deus tinha para ela, de viver num estado de graça, embora não reflita a claridade e o esplendor do Sol, o claro e indelével selo com que Deus a marcou, ali, permanecerá para sempre) ${ }^{656}$.

Assim como são claros os pequenos arroios que brotam de uma fonte clara, assim também é uma alma que está em graça, razão pela qual suas obras são tão agradáveis aos olhos de Deus e dos homens. Porque elas procedem dessa fonte de vida na qual, à semelhança de uma árvore, a alma está plantada; e ela não teria frescor nem fertilidade senão estivesse ali, sendo a água responsável pelo seu sustento e pelos seus bons frutos[...] a fonte, aquele sol resplandecente que está no centro da alma, não perde seu resplendor e formosura. Ele continua sempre dentro dela, e nada pode tirar-lhe o brilho. Mas se sobre um cristal, que está ao sol, se puser um pano espesso e escuro, claro está que, embora o sol incida nele, a sua claridade não terá efeito sobre o cristal $^{657}$.

\footnotetext{
${ }^{652}$ Cf. $1 \mathrm{M} 2,14$

${ }^{653} 3 \mathrm{M} 1,6$.

${ }^{654}$ Cf. $1 \mathrm{M} 2,5$.

${ }^{655} \mathrm{Cf} .4 \mathrm{M} 3,2$

656 "Incorporado em Cristo pelo Batismo, o batizado é configurado a Cristo. O batismo sela o cristão com um sinal espiritual indelével ('charáter') da sua pertença a Cristo, pecado algum apaga esta marca, se bem que possa impedir o Batismo de produzir os frutos de salvação". CEC 1272.

${ }^{657} 1 \mathrm{M} 2-3$.
} 
Deste modo, adentrar cada vez mais no interior do castelo é a via régia para se reconstruir a imagem de Deus rompida pelo pecado ${ }^{658}$. Contudo, embora o castelo seja a própria alma e o caminho espiritual o de sentir-se à vontade em sua própria casa para transitar, com a luz de Deus, entre umas moradas e outras, iluminando-as bem, nem todos optam por entrar. A riqueza está aí, mas, para encontrar o grande tesouro, as pessoas necessitam entrar em si mesmas, deixando de lado tudo o que impede o adentrar ${ }^{659}$.

Voltando, pois a nosso formoso e agradável castelo, temos de ver como entrar nele. Pode parecer que digo algum disparate; porque se esse castelo é a alma, claro está que não se trata de entrar, pois, se é ele mesmo, pareceria desatino dizer a alguém que entrasse num aposento estando já dentro. Mas deveis saber que há grande diferença entre os modos de estar; existem muitas almas que ficam à volta do castelo, onde estão os que o guardam[...]. Certamente já vistes alguns livros de oração aconselharem a alma a entrar em si mesma, pois é assim que penso ${ }^{660}$.

A porta do castelo - para entrar em cada nova morada, Teresa acena à porta: "pelo que posso entender, a porta para entrar nesse castelo é a oração e a reflexão. Não digo oração mental, mais do que vocal; mas para haver oração, é necessária a reflexão"661. É preciso aproximar-se, tanto quanto possível do Rei. Ao entrar no castelo, se estabelece um relacionamento com Deus. E, por mais que pareça estranha e/ou impossível esta comunicação com Ele, devido às limitações humanas, sobre este distanciamento que há entre a pessoa e Deus, Teresa diz:

Assim como não nos causa prejuízo considerar as coisas que há no céu e o que nele gozam os bem-aventurados, antes nos alegrando e nos estimulando a alcançar o que eles já fruem, tão pouco nos prejudicará ver que é possível, ainda neste desterro, comunicar-se um tão grande Deus com uns vermezinhos asquerosos como nós e amá-los com uma bondade tão plena e uma misericórdia tão sem limites ${ }^{662}$.

\section{3 .3}

Castelo Interior e seus defensores

É o grupo das pessoas com a missão de defesa dos ataques do inimigo ${ }^{663}$. Uns são mais aguerridos que outros. Os defensores dos aposentos mais baixos e exteriores têm menos força do que os dos aposentos mais altos e mais próximos de onde mora o rei. Ou seja, o rei se acerca dos defensores mais fiéis e

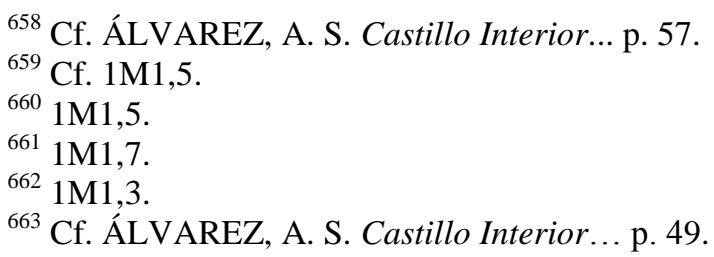


aperfeiçoados, enquanto os que estão menos aprimorados Ele os coloca mais longe, na entrada do castelo ${ }^{664}$. Desta forma, o perigo é maior nas partes mais exteriores do castelo. No grupo dos defensores, há:

Os guardas, alcaides, mordomos, mestres-sala e criados - São os sentidos e as potências da alma: inteligência, vontade e memória que protegem o castelo e estão disponíveis ao combate ${ }^{665}$. Dispostos a lutar, mas muitas vezes, enganados pelos inimigos que empregam na luta mil classes de ardis e vão se aproximando, silenciosamente, sem que os guardas dêem-se por conta do dano que fazem e, quando percebem, o estrago já está quase irreparável. Quando não realizam bem seu trabalho andam turvos, extraviados, sem rumo, em muita cegueira e mau governo $^{666}$.

Os vassalos - São os sentidos e as potências, no instante em que se apresentam com aspecto de ferozes guerreiros, nos momentos em que dão a vida por seu Senhor. Aparecem, sobretudo, nos aposentos mais altos. Aí lutam com grande força e dificilmente são vencidos.

As pessoas dos aposentos baixos - Também são os sentidos e as potências, só que agora se encontram ainda mais turvos, pois a alma já caiu em pecado. Assim, ao invés de realizarem o trabalho de defesa, ficam amortecidos. E, muitas vezes, saem a andar com gente estranha e inimiga do bem deste castelo, misturando-se com elas. Ao tornarem-se cúmplices dos inimigos, podem ser capazes de passar dias e, até mesmo, anos assim ${ }^{667}$.

\section{3 .4}

Castelo Interior e seus inimigos

Os inimigos são os que lutam contra os defensores para tomarem posse do castelo. No grupo dos inimigos encontram-se:

Os demônios - São os maiores e mais perigosos inimigos. Têm a força para combater em quase todas as moradas e causam grande prejuízo em todas elas. Em algumas moradas aborrecem mais que em outras. Teresa distingue 'demônio' e

\footnotetext{
${ }^{664}$ Estes defensores são as potências e sentidos em seus diversos matizes: quando andam turvos quando a alma fica em pecado, ou mais fortes quando ela está em estado de graça. Cf. ÁLVAREZ, A. S. Castillo Interior... p. 49-50; Ver também em Teresa 4M 3,2.

${ }^{665}$ Cf. $1 \mathrm{M} 2,11$

${ }^{666}$ Cf. $1 \mathrm{M} 2,4$.

${ }^{667}$ Cf. 4M3, 2 .
} 
'demônios'. Usa o termo no singular para apresentá-lo com força maior, como chefe dos demônios, como aquele que tem muitas legiões a chefiar no combate ${ }^{668}$. Diversos animais - Há uma gama diversificada de animais, que se referem à mesma realidade (pecado), embora com matizes diferenciados, a saber:

Peçonhentos, parasitas, alimárias e bestas - São os apetites e as paixões ${ }^{669}$, os negócios, as bagatelas e contentamentos do mundo, aos quais a pessoa muito se apega ${ }^{670}$. São animais nocivos e típicos dos arredores do castelo, mas andam por quase todo ele. São rancorosos e guardam na memória o que acontece com a pessoa para vingar-se de algum momento não ter conseguido vencer a alma. Raramente esses chegam às quartas moradas e das quartas para cima praticamente nunca passam ${ }^{671}$. Ainda que sejam animais repugnantes, as pessoas muitas vezes acostumam-se à sua companhia ${ }^{672}$ e se fazem semelhantes a estes animais peçonhentos que, mesmo que queiram, não conseguem deixar de ficar parecidos, ou presos a eles ${ }^{673}$. Como parasitas, podem-se considerar os maus pensamentos e a aridez na oração que faz a pessoa estacionar, ou retroceder a algumas peças ${ }^{674}$.

As serpentes, cobras e víboras - Sendo astuciosas, por excelência, simbolizam o engano do mundo, que envolve a pessoa em suas redes de improviso. Por sua artificiosidade, defendem-se de animais maiores, embora rastejem pelo chão. São traiçoeiras e costumam morder pelas costas, sem avisar.

As lagartixas - Representam os pensamentozinhos que procedem da imaginação ${ }^{675}$. São animais menos perigosos, mas, por serem muito delgadas, adentram até o mais interior do castelo, inclusive nas áreas mais avançadas, praticamente, até as quintas moradas, onde já não entram animais mais venenosos. $\mathrm{O}$ dano destas pode não ser grave à alma, mas são inconvenientes e molestam. Assim como o barro nos olhos, estes animais impedem a alma de enxergar melhor a luz que vem do palácio do Rei ${ }^{676}$.

E outros símbolos, como:

${ }^{668}$ Cf. 2M1,5.

${ }^{669}$ Cf. ÁLVAREZ, A. S. Castillo Interior...p. 43.

${ }^{670}$ Cf. 2M1,2.

${ }^{671}$ Cf. ÁLVAREZ, A. S. Castillo Interior... p.46.

${ }^{672}$ Cf. 1M1,6.

${ }^{673}$ Cf. $2 \mathrm{M} 1,2$

${ }^{674}$ Cf. ÁLVAREZ, A. S. Castillo Interior... p. 47.

${ }^{675}$ Ibidem. p. 48.

${ }^{676}$ Cf. 3M2,7. 
As pessoas fora do Castelo - São as que transitam de pecado em pecado e não recorrem a Deus que pode salvá-las dessa situação. Obstinam-se no afastamento de Deus, longe da fonte da vida, na qual à semelhança de uma árvore, a alma está plantada ${ }^{677}$. Deixam seus sentidos espirituais como que atados e ficam semelhantes a um paralítico, ou a um cego, com vendas nos olhos, sem existência verdadeira ${ }^{678}$. "Mostrou-me Ele, o estado da alma em pecado, fica sem nenhum poder, como alguém que estivesse de todo atado e preso, com os olhos tapados, que, mesmo querendo, não pode ver, nem andar, nem ouvir, encontrando-se em grande obscuridade" ${ }^{\circ 79}$.

Além disso, não valorizam a beleza que trazem em si mesmas, não têm interesse de entrar no castelo, não sabem o que há de precioso nesse lugar, nem Quem está dentro, nem sequer que aposentos existem ${ }^{680}$. Por quererem e sentirem prazer em estar fora do castelo, afastadas de Deus, trocam a beleza e limpidez da alma, por brutalidade, fealdade e sujeira. Atribuem valor ao que não tem valor e ficam numa situação desoladora. Desta forma, aproximam-se e mesclam-se aos animais o tempo inteiro, sem discernimento. E,

[...] é tal o seu costume de tratar sempre com os parasitas e alimárias que estão à volta do castelo que já quase se tornaram como eles. Embora de natureza tão rica e capazes de conversar com o próprio Deus, não há remédio que os cure e se não procuram entender e remediar a sua miséria, essas almas se transformarão em estátuas de sal, por não voltarem a cabeça para si mesmas, tal como aconteceu a mulher de Lot por voltá-la para trás ${ }^{681}$.

As trevas - São a ausência de luz, situação de pecado. Embora o distanciamento de Deus seja uma situação desprezível para a alma, sempre é tempo da pessoa sair deste estado, porque ela foi feita para Deus, feita para deixar resplandecer, em si, a sua imagem e semelhança. E Deus que é Pai, Irmão e Amor, continuará sempre buscando a vida verdadeira para os seus escolhidos (todos); e como para Ele nada é impossível ${ }^{682}$, mesmo que a situação de pecado perdure como a paralisia do entrevado junto à piscina (já há trinta e oito anos), ou ainda mais $^{683}$, Deus sempre almejará a salvação da pessoa e ficará aguardando-a para,

\footnotetext{
${ }^{677}$ Cf. 1M2,1.

${ }^{678}$ Cf. $1 \mathrm{M} \mathrm{1,6.}$

${ }^{679} \mathrm{C} 24$.

${ }^{680}$ Cf. $1 \mathrm{M} 1,5$.

${ }^{681} 1 \mathrm{M} 1,5-6$.

${ }^{682}$ Cf. Lc 1,37.

${ }^{683}$ Cf. Jo 5,1-9.
} 
retornar ao seio familiar, ao convívio da casa paterna, semelhante ao filho pródigo ${ }^{684}$. Teresa diz que, "se as pessoas soubessem o que significa o pecado, ninguém seria capaz de pecar, ainda que tivesse de se submeter aos maiores sofrimentos para fugir das ocasiões" ${ }^{685}$. De modo que, os efeitos do pecado grave para o ser humano são sempre muito tenebrosos, uma vez que deixam a alma suja, maculada, em trevas e, uma vez, também, que submergem a pessoa e as suas obras na própria escuridão.

Eu gostaria que considerásseis o que será ver esse castelo tão resplandecente e formoso, essa pérola oriental, essa árvore de vida plantada nas próprias águas vivas da vida, que é Deus, quando cai em pecado mortal. Não há treva tão tenebrosa, nem coisa tão escura[...] que se lhe compare. Basta dizer que o próprio sol que lhe dava tanto resplendor e formosura, se encontra ainda no centro da alma, mas é como se isso não acontecesse. [...]daí decorrendo que todas as obras que fizer, [...] são de nenhum fruto para alcançar a glória.

Isso porque não procedem do princípio pelo qual a virtude é virtude, Deus, mas nos apartam d'Ele, não podendo ser agradáveis aos seus olhos. Porque, em suma, a intenção de quem comete um pecado mortal não é contentar a Deus, mas dar prazer ao demônio. Sendo este as próprias trevas, a pobre alma torna-se também treva como ele ${ }^{686}$.

\section{4}

Características das Moradas do Castelo Interior

A partir daqui faz-se um resumo da obra Castelo Interior conservando-se a essência da obra da autora na descrição de cada morada e nos aconselhamentos que propõe para o avanço no relacionamento com Deus e com os irmãos.

\subsection{1}

\section{As Primeiras Moradas do Castelo Interior}

As pessoas destas moradas podem ser caridosas, não tem a preocupação ou o cuidado de refletir porém o fazem vez, ou outra. Contudo, ao meditar encontram-se cheias de distrações, de preocupações. São pessoas absorvidas pelo mundo, mergulhadas em prazeres, à procura de honras e vaidades humanas. Embora sejam boas e não desejam ofender a Deus, facilmente deixam-se vencer,

\footnotetext{
${ }^{684}$ Cf. Lc 15,11-32.

$6851 \mathrm{M} 2,2$.

${ }^{686} 1 \mathrm{M} 2,1$.
} 
porque os guardas destas primeiras moradas perderam a força original que por natureza Deus lhes deu, assim apresentam-se frágeis e suscetíveis no combate ${ }^{687}$.

Nestas primeiras moradas é possível ver que a luz, que vem da sala principal onde mora o Rei, está escassa ${ }^{688}$. Isto, não por culpa do aposento, porque embora o aposento não esteja tão escuro e em trevas, como quando a pessoa está em pecado, o seu interior está obscurecido, pois permitiu a entrada de cobras, víboras e outros animais peçonhentos. A pessoa acostumou-se a tratar com estes animais, chegando ao ponto de tornar-se semelhante a eles ${ }^{689}$. Por estes animais ficarem bem diante de seus olhos, encontram-se impedidos de reparar a luz e não podem vê-la, pois a pessoa fica idêntica a um cego ${ }^{690}$. Teresa recomenda às pessoas destas primeiras moradas a entrarem dentro de si mesmas. Para isso, precisam ter oração e considerar as coisas da alma com amplidão e grandeza ${ }^{691}$. É assaz importante, desde o início, ter a determinação do seguimento de Cristo e a entrar primeiro no aposento do conhecimento próprio, antes de voar aos dos outros ${ }^{692}$.

Para crescer no relacionamento com Deus, é preciso privilegiar o silêncio interior e conservar a paz ${ }^{693}$. É indispensável deixar as coisas nocivas e peçonhentas com as quais lida. Abrir mão delas e de tudo o que a dispersa e a amarra e de tudo o que é desnecessário ao seu crescimento espiritual ${ }^{694}$. Para que isso aconteça precisa-se abertura, disponibilidade de coração aos desígnios do Senhor e muita convivência com Cristo, com a Virgem Maria e com os santos, pois com Eles aprenderá a verdadeira humildade. Eles serão sua grande ajuda ${ }^{695}$. Pois, "assim como a abelha não fica ociosa na colméia, enquanto estivermos na Terra, não há outra coisa que nos importa mais do que a humildade, pois sem ela vai tudo perdido"696. Como espelho para esta virtude é bom considerar a formosura e a majestade de Deus e fixar os olhos em Cristo, nosso bem, que está sempre a chamar a pessoa para dentro do castelo.

\footnotetext{
${ }^{687}$ Cf. $1 \mathrm{M} 2,14$.

${ }^{688}$ Cf. $1 \mathrm{M} 2,14$.

${ }^{689}$ Cf. $1 \mathrm{M} 1,6$.

${ }^{690}$ Nos animais: cobras, víboras, sevandijas, sapos, Santa Teresa externaliza aquilo que de fato é prejudicial à pessoa nesta primeira morada. Cf. $1 \mathrm{M}$.

691 1M1,6-7.

${ }^{692}$ Cf. $1 \mathrm{M} 1,2$.

${ }^{693}$ Cf. $1 \mathrm{M} 2,17$.

${ }^{694}$ Cf.1M2,14.

${ }^{695}$ Cf. 2M2,11; 1M2,12.

$6961 \mathrm{M} 2,8$.
} 
Em relação à caridade para com o próximo, nesta morada é importante não descuidar do amor de uns para com os outros ${ }^{697}$, pois em momento algum se pode deixar esfriar a caridade. Deve-se cuidar o zelo indiscreto, pois causa muito dano à pessoa e a prende nessa morada. Este não é nada mais, nada menos, que a exaltação do próprio egoísmo. Sutil, ele projeta nos outros ninharias, impedindo a pessoa de ver as suas próprias dificuldades ${ }^{698}$.

\section{4 .2}

\section{As segundas moradas do Castelo Interior}

Esta é a morada dos que já se iniciaram na prática da oração. Compreenderam o quanto importa avançar em direção aonde se encontra o Rei, e deparam-se com bem mais trabalhos do que os da morada anterior ${ }^{699}$. Enquanto estes eram semelhantes aos surdos-mudos ${ }^{700}$, cegos e aos paraliticos e tem menor resistência, os que aqui estão ouvem e entendem os chamamentos divinos, mas ainda a partir de fora: através das homilias, da leitura de bons livros, dos acontecimentos, das enfermidades, das pessoas boas e por diversos meios ${ }^{701}$.

Dentro de si há um intenso combate entre a interioridade e a exterioridade. Há luta e perseverança e perseverança na luta. Enfrentam, aqui, a terrível guerra que travam os demônios ${ }^{702}$. Os inimigos apelam, sobretudo, aos fortes contrastes, procurando fazer com que a pessoa sinta as alegrias do mundo como eternas. E para o demônio, nada será pouco para ludibriar. É capaz de fazer com que todo o inferno venha a lutar contra a alma, principalmente quando vê nela condições de avançar muito. Como a pessoa dessas moradas tem a vontade e a fé fraca e ainda prefere fazer o mundo girar em torno de si mesma, vai seguir amando mais a si mesma, as vaidades e o que é visível e concreto ${ }^{703}$. Também sente necessidade e prefere agradar mais aos parentes e aos amigos, do que entregar-se, inteiramente a Deus. Se vacilar, o inimigo, muito esperto, ali está para infundir-lhe medo, de todas as naturezas: da perda da saúde, das amizades, dos bens que possui. A fé ensina a ela o que deve fazer. $\mathrm{O}$ entendimento a ajuda a refletir sobre as verdades

\footnotetext{
${ }^{697}$ Cf. $1 \mathrm{M} 21,18$.

${ }^{698}$ Cf. $1 \mathrm{M} 2,17$.

${ }^{699}$ Cf. 2M1,2.

${ }^{700}$ Cf. $2 \mathrm{M} 1,3$.

${ }^{701}$ Cf. $1 \mathrm{M} 1,3$.

${ }^{702}$ Cf. 2M1,2-3.

${ }^{703}$ Cf. $2 \mathrm{M} 1,5$.
} 
na oração e a dedicar-se à leitura de bons livros. A memória não só lhe traz as lembranças, mas recorda-lhe muitas coisas e a faz pensar sobre a realidade. Lembra-a, dos que morreram, alguns até repentinamente e outros, de como logo foram esquecidos. Vê que nas sepulturas, os que gozaram desta vida, distantes dos projetos de Deus, não passam agora de um fervilhar de vermes. A razão mostralhe o engano: de que vale tudo isso?! A vontade se ilumina, com todas as suas potências e a pessoa inclina-se a amar o Amador que lhe dá a vida e o $\operatorname{ser}^{704}$.

Por fim, reconhece não poder encontrar melhor Amigo que Cristo e que, por mais que vivesse muitos anos, não veria outra coisa, senão que as facilidades e felicidades que o inimigo lhe propõe são todas cheias de trabalhos, contradições e inseguranças. Percebe não valer a pena buscar a felicidade fora de sua casa.pois a sua está cheia de bens para saborear, se acolher em si, de todo o coração, com boa vontade, a tão divino Hóspede que mora no mais íntimo de si mesma ${ }^{705}$.

Para crescer no relacionamento com Deus, nas segundas moradas, é fundamental a pessoa tomar firme decisão de ser corajosa e definir-se para Deus, com força de vontade de perseverar até o fim. É importante ter presente que é pior a recaída que a queda ${ }^{706}$. Precisa confiar na misericórdia de Deus, assegurar-se da sua luz e não desanimar com os fracassos. Nisso estará todo o seu bem. Precisa estar disposta a ser semelhante ao varão, contudo não como os soldados de Gedeão que se deitavam a beber de bruços, quando iam para a batalha, mas como quem se coloca de pé e está de sobreaviso, decidido a pelejar contra todos os demônios, se necessário for ${ }^{707}$. Pois, quando o inimigo vê a pessoa, com resoluta determinação de entregar-se a Deus e de não voltar atrás, com a disposição de antes perder a vida, o descanso e todas as regalias mundanas que possa oferecer, muito mais depressa a deixará. É conveniente afastar-se das más companhias ${ }^{708}$. Uma boa amizade sempre ajuda, especialmente de pessoas mais adiantadas e experimentadas na oração ${ }^{709}$. Convém alimentar-se bem, contudo, não com o manjar dos porcos, semelhante ao do filho pródigo, mas com a oração ${ }^{710}$, pois é

\footnotetext{
${ }^{704}$ Cf. $1 \mathrm{M} 1,4$.

${ }^{705}$ Cf. $2 \mathrm{M} 1,4$.

${ }^{706}$ Cf. $2 \mathrm{M} 1,9$.

${ }^{707}$ Sobre os soldados de Gedeão, leia-se o texto bíblico: Jz 7.

${ }^{708}$ Cf. 2M1,6.

${ }^{709}$ Cf. $2 \mathrm{M} 1,10$

${ }^{710}$ Cf. $2 \mathrm{M} 1,4$.
} 
necessário "orar sempre, para não andar na tentação. Para a peleja: não existem melhores armas do que as da cruz"711.

Neste estágio são preciosos os momentos de recolhimento, porque como se haverá de pensar que se pode entrar no céu, sem antes entrar em si mesmo e conhecer melhor o Senhor para depois realizar as obras em seu serviço ${ }^{712}$ ? Importa muito conhecer-se ainda mais, conhecer sua miséria. Importa contemplar a humanidade, a encarnação de Cristo e olhar para Ele com amor, considerando o quanto lhe deve pela morte que sofreu em seu lugar! E, ao estar com Ele, importa pedir-lhe misericórdia e perceber, com realismo e objetividade, que o servo não é maior que o seu Senhor e que Jesus é o Caminho que leva ao Pai. Ao reconhecêlo como Amigo fiel, sentirá a paz e segurança ${ }^{713}$.

Quando tiver alguma consolação na oração é necessário recebê-la com gratuidade. Mas não se deve fixar nela, pois a única pretensão de quem se inicia na vida de oração há de ser de trabalhar e determinar-se com toda a diligência para conformar a sua vontade com a de Deus. E, mais que isso: é bom que a pessoa nem lembre que podem existir regalos e recompensas para os que principiam, porque, sem dúvida, seria algo sem firmeza alguma ${ }^{714}$. A bem da verdade, isso seria maneira muito baixa de começar a construção de um edifício tão precioso e magnífico, pois se alguém começa construindo sobre a areia, dará com tudo no chão e viverá sempre tentado(a) a querer mais deleites e ficará desgostoso(a) ${ }^{715}$. A verdadeira humildade ajuda a perceber que não são nestas moradas iniciais que chove o maná ${ }^{716}$. A chuva está bem mais adiante e é reservada para aqueles que só querem aquilo que Deus quer ${ }^{717}$. Por isso, é importante não pedir recompensas espirituais, tampouco aconselhar a Deus o que deve dar, ou ainda, buscar que Ele lhe dê aquilo que quer e que lhe faça a sua vontade $^{718}$.

É coisa que não deixa de ser engraçada: ainda estamos em meio a mil dificuldades e imperfeições, nossas virtudes ainda não sabem andar, pois só há pouco começaram a nascer [...] e não temos vergonha de querer prazeres na

\footnotetext{
$7112 \mathrm{M} 1,6$.

${ }^{712}$ Cf. $2 \mathrm{M} 1,10-11$.

${ }^{713}$ Cf. $2 \mathrm{M} 1,11$.

${ }^{714}$ Cf. $2 \mathrm{M} 1,8$.

${ }^{715}$ Cf. 2 M 7.

${ }^{716}$ Cf. 2M1,7

${ }^{717}$ Cf. $2 \mathrm{M} 1,6$.

${ }^{718}$ Cf. $2 \mathrm{M} 1,8$.
} 
oração e de nos queixar de aridez? Que isso nunca vos aconteça, Irmãs! Apegaivos à cruz que vosso Esposo tomou sobre si e entendei que esta deve ser a vossa tarefa. Aquela que mais puder padecer, que padeça mais por Ele e será a que melhor se liberta. Considerai o resto acessório e, se o Senhor vo-lo quiser dar, rendei-lhe muitas graças ${ }^{719}$.

\section{4 .3}

\section{As Terceiras Moradas Castelo Interior}

Esta é morada das pessoas que já estão habituadas ao exercício da oração e da virtude. Têm seus momentos de recolhimento e costume de meditar sobre a paixão do Senhor. São bem-aventurados, temem a Deus ${ }^{720}$. Venceram com perseverança os primeiros combates, recebendo para isso imensa graça ${ }^{721}$. São pessoas desejosas de não ofender à Deus. E tem a disposição de, por nada neste mundo, cometer um só pecado ${ }^{722}$, inclusive, guardam-se até dos mais leves, para não perdê-lo para sempre ${ }^{723}$. Por serem virtuosas ${ }^{724}$ são amigas de penitências ${ }^{725}$, embora façam-nas com discrição e adequação, para não causar-lhes dano à saúde. Isso por sua razão estar em si e o seu amor ainda não chegar a ponto de colocar a razão de $\operatorname{lado}^{726}$. Estas pessoas aproveitam bem seu tempo, exercitam-se na caridade com o próximo, são ajustadas e equilibradas no falar, no vestir, na administração de suas casas ${ }^{727}$. Como vivem já há muitos anos em retidão e na harmonia de alma e de corpo $^{728}$, gostariam que os demais vivessem $\operatorname{assim}^{729}$. Se não deixarem o que já iniciaram, andarão em uma via segura ${ }^{730}$. Se, de fato quiserem ir adiante, o Senhor não lhes negará o acesso às últimas moradas e o caminho já lhes está aberto ${ }^{731}$. Vez por outra, fazem a experiência das moradas mais elevadas, porém o comum é vê-las a lutar com securas. Por vezes, Deus afasta um pouco delas o seu favor ${ }^{732}$. A falta de consolo na oração deixa a pessoa dessas moradas descontente, quando percebe que outros têm graças superiores às

\footnotetext{
${ }^{719} 2 \mathrm{M} 1,7$.

${ }^{720}$ Cf. Sl 111,1.

${ }^{721}$ Cf. 3M1,5.

${ }^{722}$ Cf. 3M1,6.

${ }^{723}$ Cf. 3M1,2.

${ }^{724}$ Cf. 3M2,5.

${ }^{725}$ Cf. 3M1,6.

${ }^{726}$ Cf. $3 \mathrm{M} 2,7$.

${ }^{727}$ Cf. 3M1,5.

${ }^{728}$ Cf. 3M2,1.

${ }^{729}$ Cf. 3M2,5.

${ }^{730} \mathrm{Cf}$. 3M1,1.

${ }^{731}$ Cf. 3M1,5.

${ }^{732}$ Cf. 3M2,2.
} 
dela, parecendo-lhe que Deus não é justo em tratá-la assim, uma vez que lhe é tão dedicada. Não percebe que o Senhor, justo e misericordioso, sempre dá muito mais do que aquilo que a pessoa merece; jamais deixando de pagar a alma. E dá a ela o que lhe é substancioso, mais do que o que ela poderia pedir de consolos buscados nos prazeres da vida. Aqui, importa considerar que o Senhor está propondo que se conforme com a Sua vontade, que seja indiferente às moções recebidas, não querendo mais isto do que aquilo e que conserve a paz. Precisa compreender, nesta morada, que a paz e a resignação são graças ainda maiores do que aquilo que deseja receber ${ }^{733}$. Estas são, na verdade, um dom até mais valioso do que as próprias consolações ${ }^{734}$. É bom entender que os gostos na oração, quando o Senhor os dá, geralmente é para convidá-la a vislumbrar rapidamente o que se passa nas moradas mais elevadas, com o propósito de dispô-la a entrar nelas ${ }^{735}$. Quando o Senhor a prova, logo manifesta suas deficiências ${ }^{736}$. E Ele, muitas vezes o faz, para que perceba se, está desapegada das suas paixões, ou não ${ }^{737}$. Esta percepção do desapego é surpreende a pessoa porque lhe mostra que, às vezes, ela não está (grau de amor) aonde lhe parece estar. Se perde parte dos bens logo se aflige e fica angustiada como se fosse lhe faltar o pão ${ }^{738}$ e quando alguém a toca de leve na honra, entristece-se e se perturba ${ }^{739}$. Não obstante suas limitações, como já há muito tempo é virtuosa, sente dificuldade em aceitar conselhos e prefere ensinar aos outros do que ouvir, ou receber conselhos. Parecelhe que tem razão de sobra para sentir o que sente ${ }^{740}$. Canoniza seus pensamentos e faltas e gostaria que os outros também a canonizassem ${ }^{741}$. Por crer tudo ter vivido por amor a Deus, não consegue perceber que o que faz é imperfeição. Seu comportamento é semelhante ao do jovem rico: incoerente com sua oração ${ }^{742}$. Dessas incoerências resulta o mal daqueles que não vão adiante. Na maioria das

\footnotetext{
${ }^{733}$ Cf. 3M1,9.

${ }^{734}$ Cf. 3M2,4.

${ }^{735}$ Cf. $3 \mathrm{M} 2,9$.

${ }^{736}$ Cf. $3 \mathrm{M} 2,2$

${ }^{737}$ Cf. 3M2,7.

${ }^{738}$ Cf. $3 \mathrm{M} 1,4$

${ }^{739}$ Cf. 3M2,5.

${ }^{740}$ Cf. 3M2,1.

${ }^{741}$ Cf. 3M2,3.

${ }^{742}$ Cf. Mt 19, 16-22.
} 
vezes, o ponto principal que trava a pessoa e não a ajuda a avançar às próximas moradas é a falta de humildade ${ }^{743}$, que é também, o que causa o maior prejuízo ${ }^{744}$.

Ora, quando a pessoa não se deixa a si mesma, vai muito carregada aos aposentos superiores $^{745}$. Assim, a caminhada ou será lenta, ou impossível. Convém lembrar que a fortaleza do cristão, nesta morada, não está fundada em terra firme, como quem já está exercitado a padecer. Como a pessoa, ainda está muito próxima às primeiras moradas é fácil retornar a elas a qualquer momento.

É indispensável vigiar as próprias faltas, deixando de lado as dos outros. Ao Senhor cabe o cuidado das alheias. Às vezes, com boa intenção e zelo, pode-se cometer erros ao tentar impedir o pecado dos outros. O fundamental é não se descuidar em suplicar a Deus por eles e suas necessidades ${ }^{746}$. Precisa força para resistir às tentações que lhes sobrevêm ${ }^{747}$. Entrai no interior! "Transcendei vossas pequenas obras, pois, por serdes de Cristo, deveis tudo isso e muito mais ${ }^{748}$ !"

Para crescer no relacionamento com Deus, ao ver a Mãe de Deus, é importante imitá-la e considerar a grandeza dessa Senhora ${ }^{749}$. Das agruras da oração, extrair humildade verdadeira e não a inquietação, que é o que, aqui, pretende o inimigo. Os regalos, às vezes, são dados aos mais fracos ${ }^{750}$. Não basta dizer a Deus, que O deseja, é preciso observar o que fazem por Ele as almas que deveras o amam e, provar a si mesmo, ou antes, deixar que a prove o Senhor ${ }^{751}$.

[...] voltemos às corretas almas de que falávamos. Observemos o que elas fazem por Deus e $\operatorname{logo}$ veremos como não temos razão de nos queixar de Sua Majestade. Porque se lhe voltamos às costas, à semelhança do jovem do Evangelho e nos entristecemos quando nos diz o que devemos fazer para sermos perfeitos, o que pode, segundo vos parece, fazer o Senhor, se Ele há de dar o prêmio de acordo com o amor que Lhe temos ${ }^{752}$ ?

É necessário, não considerar que tudo já está feito, quando se abdicou de muita coisa por amor do Senhor, "ainda que sejam apenas as redes de São Pedro,

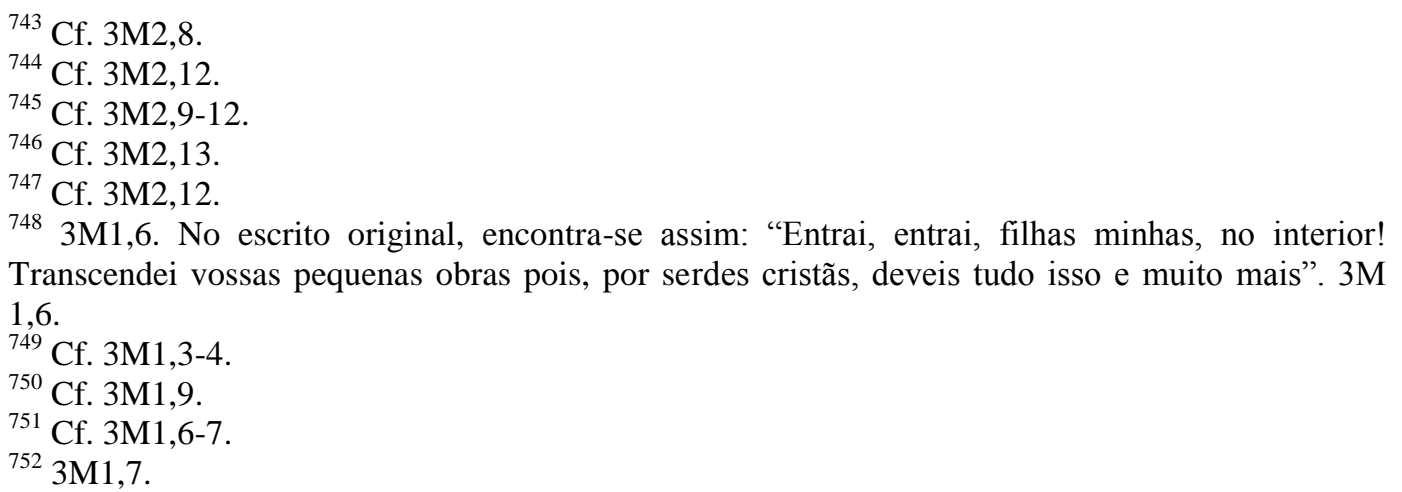


pois julga dar muito, quem dá a Deus tudo o que tem"753. Tudo isso é bom, se a pessoa persevera, mas não é suficiente. A disposição de não voltar atrás descarta, até o contato com os parasitas das primeiras moradas. Se persistir no exercício de despojamento, com certeza, alcançará o que pretende, o essencial. No entanto, diante de Deus, é bom considerar-se servo inútil para não obrigar ao Senhor conceder-lhe graças, mas, antes, saber que quem mais recebeu mais endividado com Ele se encontra. É bom pensar no que se pode fazer por um Deus tão generoso, que morreu para dar a vida a cada um. Cada pessoa pode dar-se por venturosa em amortizar um pouco do que lhe deve, por Ele tê-la servido da forma como a serviu ${ }^{754}$. A perfeição não se encontra nos "gostos e na recompensa, mas em quem mais ama, em quem melhor age com justiça e com verdade"755. Tratar com pessoas virtuosas que a ajudem, a animem e a estimulem é grandíssimo bem. É preciso deixar-se guiar por um orientador espiritual e exercitar-se na prontidão da obediência ${ }^{756}$ para em nada fazer a própria vontade, mas somente a de Deus ${ }^{757}$.

\section{4 .4}

\section{As Quartas Moradas Castelo Interior}

Nestas moradas, a pessoa já deixou o mundo e se entrega à oração com todo o esforço e esmero. Encontra-se, em um grau de intimidade com Deus, elevado, sobrenatural ${ }^{758}$. Poucas vezes, aqui, entram os animais peçonhentos e, quando entram, não fazem o menor dano, antes, deixam lucro à pessoa ${ }^{759}$. Este grau de oração é uma graça que Deus dá a quem quer, quando quer e como quer, sem afrontar com isso a ninguém. Estando a alma já mais perto de onde está o Rei é grande a sua formosura. Há ali coisas tão delicadas para ver e compreender que o intelecto não consegue dar conta de fazê-lo adequadamente. Porque tudo fica obscuro para quem não tem experiência ${ }^{760}$. Nestas moradas, a pessoa recebe muitas alegrias ${ }^{761}$ e, por meio de reflexões, meditações, com o entendimento e o afeto, colocados em Deus, vai abastecendo seu reservatório de água. Seu coração

\footnotetext{
${ }^{753} 3 \mathrm{M} 1,8$

${ }^{754}$ Cf. $3 \mathrm{M} 1,8$.

$7553 \mathrm{M} 2,10$.

${ }^{756}$ Cf. 3M2,12.

${ }^{757}$ Cf. 3M2,10.

${ }^{758}$ Cf. $4 \mathrm{M} 1,1$.

${ }^{759}$ Cf. $4 \mathrm{M} 1,3$.

${ }^{760}$ Cf. 4M1,2.

${ }^{761}$ Cf. 4M1,4.
} 
enche-se de regozijo, sente a proximidade do Senhor e descansa, n'Aquele que ama. Parece à pessoa que sua interioridade é que busca a Deus, mas não é. É Deus quem a busca e a atrai ao seu interior. Os sentidos e as potências aproximam-se mais e mais e vão se acercando d'Ele ${ }^{762}$.

Vendo o grande Rei que está nesta morada sua boa vontade, por sua grande misericórdia apresenta-se à alma como Bom Pastor e, com um silvo muito suave, faz com que, quase mesmo sem entender o que acontece, a alma reconheça a sua voz e a identifica entre outras vozes. Tem tanta força esse silvo do pastor em seu interior que a pessoa deixa, com toda prontidão e confiança, as coisas exteriores nas quais estava dispersa. Entra rapidamente em seu castelo interior. Assim, ao som da voz do Bom Pastor segue-a e já não se sente mais perdida. A doce voz a auxilia a regressar e a permanecer na sua morada. Quando Deus concede esta graça, faz a pessoa sentir, notavelmente, um recolhimento suave no interior ${ }^{763}$. Enquanto quer seguir a regar seu horto, percebe uma doce quietude e o Esposo mesmo dá-se ao trabalho de regar as flores. Deixa-a ficar em paz. Como se, de muito dentro de si, brotasse-lhe essa suavidade tão grande, vinda de uma fonte silenciosa que vai crescendo e inundando todas as potências, os sentidos e o corpo inteiro. Percebe que seu pobre reservatório já não é capaz de contê-lo, porque a fonte é como um rio de água viva que brota em seu interior, a partir do centro e vai transbordando sempre mais, aumentando, a água e a capacidade da alma de saborear o gosto de Deus ${ }^{764}$. É a experiência do salmo que diz: quando me dilataste o coração ${ }^{765}$. É como se, nesse abismo íntimo, houvesse um braseiro, onde se lançam finíssimos perfumes. Não se vê o fogo, não se percebe onde arde, não se percebe o calor, mas vapores olorosos penetram a alma toda e não raramente seus efeitos fazem-se sentir no corpo $^{766}$. A prova de que Deus esteve com a pessoa e de que a pessoa esteve em Deus se verá, nos frutos. A fé será mais viva. Maior a humildade e o desapego do mundo. Perde-se o temor servil e adquire-se o temor de cometer erros. Sente-se mais forte na penitência. Em todas as virtudes fica melhorada e fortalecida ${ }^{767}$. Para seguir crescendo precisa cuidar-se

\footnotetext{
${ }^{762}$ Cf. $4 \mathrm{M} 2,4$.

${ }^{763}$ Cf. $4 \mathrm{M} 3,3$

${ }^{764}$ Cf. $4 \mathrm{M} 2,4$

${ }^{765}$ Cf. $4 \mathrm{M} 2,5$

${ }^{766}$ Cf. 4M2,6.

${ }^{767}$ Cf. 4M3,9.
} 
para não se colocar em tentação, porque o inimigo tenta mais a estas pessoas, uma vez que são uma mescla de natural e sobrenatural ${ }^{768}$.

Quando passar a atuação sensível do que o Senhor ofereceu, não é certo esperar vir o fogo do céu para consumar o sacrifício. Tampouco esperar milagres. O Senhor quer que se ajude em tudo, no que puder. Quando não está aceso o fogo da vontade e não sente a presença do Senhor, é necessário buscá-lo na vida. Sobretudo, perguntando às criaturas a respeito de Deus e de quem as fez. Não deve ficar pasma, boba, perdendo tempo em esperar que Ele lhe dê novamente o que alguma vez lhe deu. Sabe o caminho de praticar os mandamentos e seus conselhos. Nisso precisa andar diligente. O mais venha quando o Senhor quiser ${ }^{769}$.

A grande dificuldade da pessoa, destas moradas, vem particularmente da imaginação, porque ela sempre voa tão depressa, tão alto e é tão instável, que não se pode detê-la ${ }^{770}$. É preciso saber aproveitar a imaginação fixando-a na oração, pois, geralmente, enquanto as faculdades superiores permanecem em Deus, a imaginação fica como a louca da casa nos arrabaldes do castelo, padecendo com os animais ferozes e venenosos ${ }^{771}$. Contudo, por causa das distrações não se deve deixar a oração, o que seria, a pretensão do inimigo, que sabe que, por meio do relacionamento intimo e profundo com Deus a pessoa produzirá muitos frutos na Igreja. Importa é continuar a oração, fazendo nela reiterado uso da vontade e do entendimento $^{772}$ e deixar-se conduzir pela graça. Por ser pertença de Deus, que “faça Ele de nós aquilo que quiser”!Para crescer no relacionamento com Deus e com os irmãos as pessoas das quartas moradas precisam ter presente a misericórdia de Deus para consigo e "ter humildade, porque por ela se deixa render o Senhor a tudo o que queremos",773. É importante lembrar a oração "não está em muito pensar, mas em muito amar" e que é bom "fazer aquilo que mais desperte o amor" ${ }^{774}$, procurar a honra e glória de Cristo e a participação na Igreja.

A preparação para estas moradas está na humildade. Aqui se manifesta no desejo de não ter gostos pessoais, de padecer e de buscar o Senhor. Importa esquecer-se a si mesma, de sua honra, glória e de seu gosto! Deus não está

\footnotetext{
${ }^{768}$ Cf. $4 \mathrm{M} 3,10$

${ }^{769}$ Cf. $4 \mathrm{M} 3,11$.

${ }^{770}$ Cf. $4 \mathrm{M} 1,8$.

${ }^{771} \mathrm{~V} 17,7$.

${ }^{772}$ Cf. 4M1,9.

773 4M2,9.

${ }^{774} 4 \mathrm{M} 1,7$.
} 
obrigado a dar gostos, como está comprometido em dar a glória, ao serem guardados seus mandamentos. Sem gostos e consolações, as pessoas salvam-se. O Senhor sabe o que convém a cada um e quem $\mathrm{O}$ ama de verdade ${ }^{775}$. Se Ele deu as potências, não é para deixá-las encantadas, mas para usá-las em prol dos irmãos e louvá-lo muito. É justo reconhecer a grandiosidade do favor recebido de Deus ${ }^{776}$.

\section{4 .5}

\section{As Quintas Moradas Castelo Interior}

As quintas moradas são o caminho para uma união mais íntima e profunda com Deus, o matrimônio espiritual. Quem aqui se encontra está como que adormecido para as alegrias mundanas. Fez uso dos meios que o Senhor deixou na Igreja para realizar o caminho de sua salvação e está próximo dos sacramentos. Vive intensamente dedicado aos irmãos e emprega nesse exercício seus desejos, suas forças a agradar a Deus ${ }^{777}$ servindo-o em tudo ${ }^{778}$. Ainda que fosse apenas para se achegar à porta, já seria grande a misericórdia do Senhor ${ }^{779}$.

Esta morada está cheia de riquezas, tesouros e deleites ${ }^{780}$. Não há com o que se comparar as grandezas que Deus lhe mostra. A intensa vida de oração a ajuda a ter uma intensa vida humana. Quando não reconhece algo por experiência, fica em dúvida sobre o que lhe acontece: se é ilusão, sonho, algo dado por Deus, ou transfiguração do inimigo, em anjo de luz. Quando é verdadeira união com Deus, o inimigo não pode se aproximar, nem fazer prejuízo, pois o Senhor encontra-se intimamente unido à essência da alma. ${ }^{781}$.

Para melhor explicar o que se passa com a pessoa nas quintas moradas é importante fazer uma comparação com a natureza: a alma é semelhante ao bicho da seda. Quando bem pequeno se parece com a semente dos grãos de pimenta. Com o calor, no momento em que as amoreiras começam a ter folhas, a semente começa a viver. A sementinha do bicho da seda cria-se com as folhas e o bicho da seda cresce. Quando está maior e as árvores colocam seus ramos, o bicho da seda vai por si mesmo, desfiando a seda e fazendo casulos apertados, onde depois se

\footnotetext{
${ }^{775}$ Cf. 4M2,9.

${ }^{776}$ Cf. $4 \mathrm{M} 3,4$

${ }^{777}$ Cf. 5M1,4.

${ }^{778}$ Cf. $5 \mathrm{M} 1,7$.

${ }^{779}$ Cf. $5 \mathrm{M} 1,2$.

${ }^{780}$ Cf. 5M1,1.

${ }^{781}$ Cf. 5M1,5.
} 
encerram e onde acabará este verme, que é grande e feio ${ }^{782}$. Da mesma forma, a alma começa a ter vida a partir do momento em que, com o calor do Espírito Santo, aproveita do auxílio geral que Deus dá a todos, através dos meios que deixou em sua Igreja: confissões, sacramentos, homilias, $\operatorname{conselhos}^{783}$. Vai se sustentando até estar bem crescida. Depois, começa a lavrar a seda e a edificar a casa onde há de morrer, que é Cristo ${ }^{784}$. Em dado, momento: óh, maravilha! Rompe-se o casulo, irrompe-se o humano e a natureza se integra ainda mais: óh, grandeza de Deus! Sai uma borboleta branca, graciosa, a bailar: "Óh ver o desassossego dessa borboletinha, apesar de nunca ter estado mais quieta e tranquila em sua vida, é coisa para louvar a Deus" ${ }^{\text {785 }}$ ! O que foi que fez romper o casulo e transformar o verme nesta linda borboleta? Não foi, com certeza, seu esforço, não teria capacidade para tanto! Deus a tocou na substância de seu ser. Manifestou-se a ela, processando a metamorfose, a ponto de transfigurá-la ${ }^{786}$.

Agora a borboleta branca quer manter-se sob seu olhar de amor! Veja-se o desassossego dessa mariposa! Nasceram-lhe asas! Não caminha, voa em direção ao foco da luz divina, deseja consumir-se em holocausto aos interesses do Amado. Aspira louvar ao Senhor, desfazer-se e morrer por Ele mil mortes ${ }^{787}$, caso preciso. Tem em pouca conta obras que antes fazia. Tudo o que faz por Deus parece pouco. Procura ir, ainda mais adiante no serviço do Senhor. Dedica-se à obediência. Não quer manipular a lei de Deus, nem obter consolos. Deseja penitência, busca a solidão, quer padecer grandes trabalhos. Almeja que todos conheçam a Deus. Não quer, ver a Deus ofendido. Sofre pelas pessoas, por quem se perde e gostaria de trabalhar pela salvação delas até o fim do mundo. Compreende, o amor de Deus e do próximo e vive em contínua caridade ${ }^{788}$.

"Não ouvistes dizer que o Senhor fez a esposa entrar na adega de seus vinhos e ordenou nela a caridade" ${ }^{, 789}$ ? Quando o Senhor vê a alma toda rendida, completamente entregue às suas mãos, tomada de amor, a introduz na morada. Não diz que ela entrou por si mesma. Esta oração mostra-se como a adega, onde

\footnotetext{
${ }^{782}$ Cf. $5 \mathrm{M} 2,2$.

${ }^{783}$ Cf. $5 \mathrm{M} 2,3$.

${ }^{784}$ Cf. 5M2,4.

${ }^{785} 5 \mathrm{M} 2,7-8$.

${ }^{786}$ Cf. 5M2,8.

${ }^{787}$ Cf. 5M2,7-8.

${ }^{788}$ Cf. 5M3,3.

789 5M2, 12.
} 
apraz ao Senhor introduzir a alma quando e como quer. Ninguém consegue entrar por seus esforços. Somente a ação de Deus pode introduzi-la no centro da alma. É desejo do Senhor que a pessoa saia de lá assinalada com o selo divino, embora ela não saiba como entender. Fica como a cera em relação ao selo que não se grava a si mesma, mas dispõe-se unicamente a receber a impressão. Apenas permanece quieta, consentindo receber a marca ${ }^{790}$. Assim a alma, se dispõe para o Senhor, deixando-O imprimir nela a Sua marca. Tem a clareza do encontro: pois "Deus se fixa a Si mesmo no interior da alma, de modo que, quando volta a si, de nenhuma maneira pode duvidar que esteve em Deus e Deus nela"791. Jamais o esquece! Mas se não fizer mais do que receber esta mercê e ficar descuidada julgando-se segura e desviar-se do caminho do céu que consiste na observância dos mandamentos, que lhe acontecerá?

Acontecer-lhe-á como à borboleta que sai do bicho da seda. Deita a semente para nascerem outras, enquanto ela morre e fica morta para sempre. Digo que deita a semente, porque creio que Deus quer que uma graça tão grande não seja concedida inutilmente. Se a alma não se beneficia a si, com ela, que sirva de proveito para outros. Porque, como fica com esses desejos e virtudes durante todo o tempo em que perdura no bem, ela beneficia outras almas, comunicandolhes calor, a partir do seu próprio calor. E mesmo, depois de perdido esse calor, ainda lhe fica a ânsia de fazer bem aos outros e o gosto de lhes comunicar os favores concedidos por Deus a quem $\mathrm{O}$ ama e serve ${ }^{792}$.

Assim, para explicar o caminho da união com Deus, não há outra comparação melhor do que a do sacramento do matrimônio ${ }^{793}$. O sentido da união das quintas moradas compara-se à proximidade dos que desejam unir-se em casamento $^{794}$. Tudo é amor e suas operações são tão delicadas e suaves que não há palavras para descrevê-las, no entanto o Senhor sabe bem como dá-las a sentir ${ }^{795}$. Na oração, Deus manifesta a sua grandeza,o seu amor e a sua misericórdia. Há união nesta morada. Uma união que não é mística, nem experimental, mas uma união real e verdadeira, que a alma deve buscar sempre durante toda a sua vida: é a união da sua vontade com a vontade de Deus, à luz da fé ${ }^{796}$.

\footnotetext{
${ }^{790}$ Cf. 5M2,12.

${ }^{791}$ 5M 1,9.

${ }^{792} 5 \mathrm{M} 3,1$.

${ }^{793}$ Cf. 5M3,2-3.

${ }^{794}$ Cf. 5M4,1.

${ }^{795}$ Cf. 5M4,2.

${ }^{796}$ Cf. 5M3,3.
} 
Deste modo, nas quintas moradas, como Deus já conhece bem a alma, somente a alma necessita conhecer a Deus. Aqui, tem uma visão secreta daquele a quem irá tomar por Esposo. Através dos sentidos e faculdades interiores, poderia não entender em mil anos o que, com essa graça, entende num átimo. Sendo tal o Esposo, basta Sua visão para que a alma se torne digna do enlace e dê-lhe a mão. Fica tão enamorada, que tudo faz para não romper este divino noivado. Muitas graças. Muito maiores do que se possa avaliar! $!^{797}$

Embora a comunicação com Deus se dê num brevíssimo encontro, o demônio se esforça em perturbá-la e desviá-la do noivado espiritual. Para melhor usar de sua sutileza e astúcia, dispõe-se a juntar o inferno inteiro para investir contra ela, pois sabe, por experiência, que se for a Deus, em tão elevado grau de comunicação, não somente será uma alma a se perder, mas, com ela, mas uma multidão ${ }^{798}$. Se estiver a perder-se, o Rei sente tanto a perda dessa alma que lhe dá, de mil maneiras, mil avisos interiores, de modo a não poder esconder de si mesma sua própria destruição ${ }^{799}$. Contudo, se há de ser ruim, é preferível que seja no princípio, a sê-lo depois, quando pode causar prejuízo a tantas pessoas ${ }^{800}$.

Se olhamos a grande quantidade de almas que Deus atrai a Si por meio de uma, somos levadas a louvá-Lo muito pelos milhares de conversões conseguidas pelos mártires, por exemplo, uma donzela como Santa Úrsula! E quantas almas terão sido arrancadas do demônio por São Domingos, São Francisco e outros fundadores de Ordens, como é o caso, hoje do Padre Inácio, que fundou a Companhia! Está claro que todos, como o lemos recebiam graças semelhantes de Deus. A que se atribui isso senão ao fato de que eles se esforçaram por não romper por sua culpa tão divino noivado?[...] Quão disposto está o Senhor a conceder-nos as mesmas graças que concedeu a eles. E, de certo modo, tem agora mais necessidade de quem as queira receber, porque há poucos os que zelam pela Sua honra, muito menos do que antes. Temos extremo amor a nós mesmos, demasiado apego aos nossos direitos! Oh, que engano tão grande ${ }^{801}$ !

Mas quando o inimigo vê a pessoa inteiramente rendida ao Noivo, já não se atreve a tanto, porque tem medo dela e sabe que, se alguma vez se aproximar, ele mesmo ficará com grande prejuízo, enquanto a alma sairá até com maior lucro ${ }^{802}$. Assim a alma tece seu casulo e ela mesma busca a morte do verme para viver com

\footnotetext{
${ }^{797}$ Cf. $5 \mathrm{M} 4$.

${ }^{798}$ Cf. 5M4,6.

${ }^{799}$ Cf. 5M4,9

${ }^{800}$ Cf. 5M4,5.

${ }^{801} 5 \mathrm{M} 4,6$.

${ }^{802}$ Cf. 5M4,5.
} 
Cristo, em Deus ${ }^{803}$. Adere à vontade divina e ama a Deus e aos irmãos com verdadeiro amor teologal, não mais com amor sensível. Esse é o sinal mais certo de que ama verdadeiramente ao Senhor ${ }^{804}$, pois o amor jamais está ocioso. Já que pretendeu ser esposa do próprio Deus, não poderá se deitar a dormir. Tudo o que faz e padece em seu serviço é pouco. Quando algum irmão sente alguma dor, quer senti-la também; se é necessário, jejua para que ele coma, alegra-se em conhecer a virtude dos outros; quando vê uma falta em alguém, percebe essa falta como sua pede a Deus por esta pessoa e, aos olhos dos outros, se puder, encobre essa falta. Se vê alguém elogiar a um outro, se alegra muito mais do que se fosse um elogio a si mesma ${ }^{805}$. A caridade é real, está desenvolvida,procede da raiz do amor de Deus e lhe acompanha a humildade ${ }^{806}$. Se avançar abrasada no amor ${ }^{807}$, o caminho é certo, seguro e verdadeiro. Um dia poderá dizer, também: minha vida é Cristo ${ }^{808}$ !

Para crescer no relacionamento com Deus precisa empenhar-se em conhecêlo ainda mais, aproveitar as manifestações da sua misericórdia, do seu amor e procurar ir adiante no seu serviço. É importante observar, retamente, a lei de Deus ${ }^{809}$. É preciso entregar-se, nas mãos de Cristo pela veemência de um grande amor e, aí, consumir-se em holocausto aos interesses do Amado, morrendo por Ele mil mortes, se preciso for. Importa trabalhar pelo bem de todos, vivendo em contínua caridade $^{810}$. Importa não se descuidar em nada e afastar-se das ocasiões de pecado porque, mesmo neste estado, a pessoa não está suficientemente forte, só terá maior segurança depois de celebrado o noivado espiritual, mas é preciso nunca estar confiada em $\mathrm{si}^{811} \mathrm{e}$ estar atenta às sutilezas do inimigo, que gosta muito de apresentar o mal com vistosa aparência de bem ${ }^{812}$.

\footnotetext{
${ }^{803}$ Cf. 5M2,6.

${ }^{804}$ Cf. 5M3,8.

${ }^{805}$ Cf. 5M3,10-11.

${ }^{806}$ Cf. $5 \mathrm{M} 3,9$.

${ }^{807}$ Cf. 5M4,10.

${ }^{808} 5 \mathrm{M} 3,9$.

${ }^{809}$ Cf. 5M3,2.

${ }^{810}$ Cf. 5M4,5.

${ }^{811}$ Cf. 5M4,9.

${ }^{812}$ Cf. 5M4,8.
} 


\subsection{6}

\section{As Sextas Moradas Castelo Interior}

Nestas moradas, alternam-se os grandes sofrimentos da noite do espírito às altas experiências místicas cristológicas. A branca pomba, ferida pelo amor do Esposo procura, mais ocasiões para estar a sós ${ }^{813}$. A alma fica determinada a não tomar outro Esposo. Contudo, Ele não atende logo a seus grandes desejos de que já se façam os desposórios, porque Ele "quer que os deseje ainda mais e que lhe custe algo este bem, maior que todos os bens" ${ }^{\prime 814}$. Entra, pois, a alma no túnel da noite tenebrosa do espírito. Se a pessoa entendesse antecipadamente o quanto lhe resta sofrer, dificilmente se determinaria a enfrentar tudo o que está diante de si.

Aqui é provada em todos os seus relacionamentos. Enfrenta, por exemplo, murmurações das pessoas próximas e desconhecidas. Pessoas antes tidas por amigas afastam-se e são as que lhe causam os maiores sofrimentos. Algumas se referem a ela, dizendo: ali está aquela perdida e enganada; ou então: suas manifestações são coisas do demônio; acontecerá a ela como a fulano, ou sicrano, que se perdeu completamente na virtude; ou ainda: esta é uma pessoa que engana os confessores, etc. Por todos os lados, é mal interpretada, julgada, incompreendida. Isso sem falar que, às vezes, são muito difamadas e, semelhantes críticos, podem até procurar seus orientadores e convencê-los, citando exemplos do que ocorre com alguns que se perderam. Recebe provações, ditos e zombarias dessa espécie e de outras, inclusive vindo daqueles nos quais mais confia ${ }^{815}$.

Acrescem-se aos sofrimentos (psíquicos) os físicos, as enfermidades gravíssimas que, às vezes, prolongam-se por $\operatorname{anos}^{816}$. A dor de seus pecados é tão forte que deseja morrer para não sentir a amargura de ter sido tão ingrata para com Aquele a quem tanto deve $\mathrm{e}^{817}$. Parece que suas grandes iniquidades não podem comparar-se às de criatura alguma. Todo seu receio é de que Deus retire dela sua mão. As graças concedidas são como um rio que passou. A dor de sua vida pecaminosa é como um lodaçal que perdura sempre. Teme, mais que o inferno,

\footnotetext{
813 Pombinha, borboleta, ou borboletinha $(6 \mathrm{M} 4,1)$ na qual se metamorfoseou a crisálida do capítulo anterior. A alegoria do bicho da seda talvez chegue a prevalecer sobre a do "castelo" nos capítulos seguintes; quase todos começam com a típica alusão à pombinha ou a borboletinha. Cf. TOMÁS A. Introdução à obra do Castelo Interior... 5M, nota 1.

${ }^{814} 6 \mathrm{M} 1,1$.

${ }^{815}$ Cf. 6M1,3-4.

${ }^{816}$ Cf. 6M1,6.

${ }^{817}$ Cf. 6M1,8
} 
ver irados os mansos e formosos olhos do Senhor. Quando é grande o fogo que arde no interior, por mais duro que seja o coração, põe-se a destilar como um alambique. As lágrimas vêm de Deus, reconfortam e pacificam, não causam desassossego. Raramente, fazem mal. São diferentes das lágrimas dos motivos humanos e naturais, ou das de falta de humildade, que não têm o mesmo efeito.

De repente, a partir das sétimas moradas, Deus chama a alma como que por um cometa, um relâmpago, um trovão, um silvo, ou ainda, por um outro sinal. Ela percebe a presença oculta do Amado $^{818}$. As potências e os sentidos não se movem. Aquele que faz parar o sol para Josué faz parar nela a ação do entendimento ${ }^{819}$. Ela percebe substanciais suas palavras, porque realizam o que dizem. São conforme a Sagrada Escritura e imprimem-se firmemente em sua memória. Seus efeitos são de humildade, de paz e confiança, sempre. A alma sente que Cristo a olha e lhe diz: "não tenhas medo, Sou Eu"820!

Não O capta com olhos naturais, nem com os sentidos, mas tem a certeza de Sua presença ${ }^{821}$. É a visão intelectual ${ }^{822}$. Deixa como efeito a paz, o desejo de contentar a Deus, o desprezo das coisas mundanas, a humildade e a limpidez de consciência. A graça é análoga a um estojo de ouro que contém uma pedra preciosa de enorme valor e admiráveis qualidades. Tem a certeza de que a pedra está ali, embora nunca a tenha visto. A pessoa não pode abrir o relicário, somente o dono da jóia conhece o segredo de abrí-lo ${ }^{823}$. De repente, ao dono apraz abrirlhe o relicário, para dar prazer a quem o emprestou. Depois disso, a alma tem um contentamento maior ao recordar o admirável resplendor da pedra esculpida na memória. É a visão imaginária. Mais conforme ao natural, mais proveitosa ${ }^{824}$.

Quando o Rei é servido de favorecer com maior ternura esta alma, mostralhe, claramente, sua Sacratíssima Humanidade, porquanto seja com a rapidez de um relâmpago, a imagem gloriosíssima fica profundamente impressa na sua imaginação ${ }^{825}$. Não é pintada, mas viva como o sol, como um diamante de

\footnotetext{
${ }^{818}$ Cf. 6M2,2-3.

${ }^{819}$ Cf. $6 \mathrm{M} 3,18$.

${ }^{820}$ Cf. 6M3,5.

${ }^{821}$ Cf. 6M2,3.

${ }^{822}$ Cf. 6M4,5; No trecho a seguir a santa explica a visão intelectual: V 27,3.

${ }^{823}$ Cf. 6M9,2.

${ }^{824}$ Teresa explica as visões imaginárias: V28,4-7.

${ }^{825}$ Cf. 6M9,3.
} 
grandíssima majestade ${ }^{826}$. Quando menos espera o pensamento está abstraído, longe de julgar que verá algo. Apresenta-se, de repente, para ela a visão inteira e preenche-lhe as faculdades e os sentidos que, mergulham no temor, no alvoroço e na comoção. A pessoa fica semelhante a São Paulo, derrubado do cavalo. Em seguida, em grande paz. A verdadeira Sabedoria se comunica com a alma. Compreende verdades tão profundas que já não sente necessidade de outros mestres. Fica com muita humildade, fortaleza e com tal certeza de que aquilo que sente vem de Deus. Por mais que as pessoas lhe digam o contrário, ninguém consegue infundir o temor de ter sido enganada, tal é sua convicção. Percebe que o inimigo não poderia cumulá-la de tantos bens ${ }^{827}$. "Estais lembradas daquele reservatório de água do qual falávamos nas quartas moradas? O qual se enchia com suavidade, mansidão, sem nenhum movimento"? ${ }^{828}$ Assim Deus, detendo as fontes das águas, não permite aos mares saírem de seus limites e parece abrir todas as represas dos mananciais de onde vem a água a este reservatório.

Com grande ímpeto, levanta-se uma onda tão vigorosa que faz subir muito alto o barco da alma. Nem o piloto, nem os que manejam um navio são capazes de manter o equilíbrio, quando o mar está bravo e as ondas investem com furor. Assim, aqui, a alma não pode deter-se interiormente aonde quer, nem consegue dominar os sentidos, as faculdades, necessita subtrair-se aos impulsos que os movem $^{829}$. O Sol, estando no céu, sem mudar de posição, num breve instante e com força envia seus raios. A pessoa permanece em seu lugar, mas pelo calor que lhe dá o verdadeiro Sol de justiça, eleva-se acima de si mesma, mediante a parte superior do espírito, enquanto em seu interior levanta-se uma espécie de vôo e são mostradas à alma grandes coisas ${ }^{830}$.

Quando volta a sentir-se novamente em si, tudo na terra parece-lhe cisco, em comparação ao que viu. O Senhor a fez vislumbrar a Terra para onde há de ir, semelhante ao modo como os mensageiros do povo de Israel trouxeram amostras da terra de promissão, para suportarem melhor os sofrimentos do caminho tão penoso. O camarim que se encontra nos aposentos dos grandes senhores conserva inúmeros objetos de valor, como: jarros de cristal, de porcelana, de todos os

${ }^{826}$ Cf. 6M9,4.

${ }^{827}$ Cf. $6 \mathrm{M} 9,10$.

${ }^{828} 6 \mathrm{M} 5,3$.

${ }^{829}$ Cf. 6M5,3

${ }^{830}$ Cf. 6M5,1. 
feitios. Vendo-os de relance percebe a todos, mas, depois, é impossível defini$\operatorname{los}^{831}$. Quando o Senhor revelar à alma muitos segredos em arroubamentos, já não saberá relatá-los. Fica como Moisés que, provavelmente, terá entendido muito mais do que o fogo numa sarça para ter a coragem de empreender a saída do Egito $^{832}$ e como Jacó, ao ver os Anjos subindo e descendo da escada ${ }^{833}$.

O vôo do espírito é quando ele é arrebatado com velocidade. Às vezes, o corpo se assusta, porque não sabe quem o leva, nem para onde, nem pode resistir $^{834}$. No arroubamento, Deus rouba a alma para si, como sua própria ${ }^{835}$. O desposório faz-se num arroubamento e a pessoa não resiste: ouve uma palavra no interior, cresce-lhe uma centelha, sente-se abrasada como uma ave fênix e percebe-se inteiramente renovada. São perdoadas todas as suas culpas ${ }^{836}$. Durante o grande êxtase, fecha as potências e os sentidos como portas e muros das moradas do castelo, de maneira que a alma não pode atender ao exterior, pois Deus deixa aberta somente a porta onde Ele se encontra, para que consiga entrar somente ali $^{837}$. As mãos ficam frias. $\mathrm{O}$ entendimento e a vontade presos ao amor de Deus e desapegados das criaturas. A alma deseja mil vidas para empregá-las em Deus e queria que todas as suas forças fossem línguas para louvá-lo. As penitências de sua vida parecem poucas, diante de tamanho bem ${ }^{838}$. E, a borboleta, tendo saído de seu estado de verme, não consegue achar pouso nem descanso ${ }^{839}$. Deste modo é capaz de acender ainda mais o fogo do amor que a faz voar. Os arroubamentos em público começam a ser frequentes. Logo se desencadeiam para a pessoa ditos mordazes e perseguições. A pobre alma quer andar sem temores, mas isso não lhe é possível. Muitos são os que lhe suscitam medos, de modo particular, os confessores que, agora, sensivelmente se tornam para ela juízes ${ }^{840}$.

Após tantas e tão altas graças, deseja regozijar-se no Senhor. Vive em tormento, conquanto saboroso. Com lágrimas suplica, continuamente, a Deus que a tire desse desterro, pois aqui tudo quanto vê a cansa. Tem algum alívio quando

\footnotetext{
${ }^{831}$ Cf. $6 \mathrm{M} 4,8$.

${ }^{832}$ Cf. $6 \mathrm{M} 4,7$

${ }^{833}$ Cf. 6M4,6.

${ }^{834}$ Cf. 6M5,2.

${ }^{835}$ Cf. 6M4; 16-17.

${ }^{836}$ Cf. 6M4,3.

${ }^{837}$ Cf. 6M4,9;13.

${ }^{838}$ Cf. 6M4,15.

${ }^{839}$ Cf. 6M4,1.

${ }^{840}$ Cf. 6M1,8.
} 
está na solidão, mas sempre volta a saudade da busca de Deus que vai aumentando seu sofrimento de forma difícil de se explicar. Percebe-o como um golpe de fogo que a fere agudamente, no íntimo da alma. Aí, esse raio tão repentino e fugaz, deixa reduzido a pó o que encontrade terreno. Ata-lhe as faculdades. A alma fica tão angustiada que prorrompe em clamores. Tem a impressão de que vai morrer. É o purgatório ${ }^{841}$ !

O corpo fica desconjuntado, com grandíssimas dores. Entre todos os sofrimentos da terra, não há maior do que este. Sente estranha solidão. Pessoa alguma parece fazer-lhe companhia, nem as da Terra, nem mesmo as do céu. $\mathrm{O}$ único alívio que tem é ver todas as pessoas n'Aquele a quem ama, senão no mais tudo é tormento. Sente-se suspensa no ar e parece já não encontrar apoio na Terra, contudo ainda não pode subir ao céu. Abrasada em sede, não consegue alcançar a água, tão pouco pode ser saciada, se não for com a água da qual o Senhor falou à samaritana. Mas esta ninguém a dá, pois ela serve para purificar os que estão para entrar no céu ${ }^{842}$.

Numa visão, o verdadeiro Consolador a consola e a fortalece ${ }^{843}$. O sofrimento foi penoso, mas alcança nele grandíssimos efeitos: perde o medo de padecer, despreza o vil, desapega-se ainda mais das criaturas; concentra a sua atenção na pessoa de Cristo, que foi o seu caminho desde o início da caminhada, sua verdade na comunicação divina e sua vida para a qual quer viver. Percebe que só o Criador é capaz de consolá-la e satisfazê-la, logo, aumenta o temor e o cuidado para com as coisas de Deus ${ }^{844}$. O Senhor dá força aos necessitados e em tudo defende essas. Responde por elas nas perseguições e acusações que passa como o fez à Madalena, não por palavras, mas por obras ${ }^{845}$.

Para crescer no relacionamento com Deus pessoas destas moradas precisam esperar, tudo, somente de Deus e da misericórdia divina, que nunca falta aos que n'Ele se confiam ${ }^{846}$. Continuar a ocupar-se em obras de caridade, pois a força do amor a ensina o que pode fazer pelos irmãos ${ }^{847}$.

\footnotetext{
${ }^{841}$ Cf. $6 \mathrm{M} 11,2$.

${ }^{842}$ Cf. 6M11,5.

${ }^{843}$ Cf. 6M11,9.

${ }^{844}$ Cf. 6M11,10.

${ }^{845}$ Cf. 6M11,12.

${ }^{846}$ Cf. $6 \mathrm{M} 1,14$.

${ }^{847}$ Cf. $6 \mathrm{M} 1,16$.
} 


\subsection{7}

\section{As Sétimas Moradas Castelo Interior}

Abriu-se uma grande porta. Simbólica, porque na realidade não existe porta entre as sextas e as sétimas moradas, pelo menos não fechada. Parece que aqui já está tudo dito do caminho espiritual, de modo que não é possível ficar mais nada por dizer. "Mas quem poderá contar as misericórdias e as grandezas de Deus" ${ }^{848}$ ? Quando à Sua Majestade é servido de fazer à pessoa a mercê deste divino matrimônio, primeiro insere-a em Sua morada, que é esta sétima, depois o Senhor a junta consigo. Aí, por certo modo de representação da verdade possibilita a ela ver a Santíssima Trindade. Todas as três Pessoas numa nuvem de enorme claridade apresentam-se com uma admirável notícia! A alma entende, com grandíssima verdade, ser todas as três Pessoas uma só substância, um só poder, um só saber e um só Deus ${ }^{849}$.

Todas as três Pessoas comunicam-se com a alma e lhe dão a entender as palavras nas quais o Evangelho descreve o que disse o Senhor "que viriam Ele e o Pai a morar naquela alma que o ama e guarda seus mandamentos" ${ }^{~} 850$. Conserva esta presença ${ }^{851}$. Não depende dela tornar a vê-las, mas unicamente do Senhor ${ }^{852}$.

Neste divino e espiritual matrimônio, quando o Senhor aparece no centro da alma, não passa pelas potências, assim como apareceu aos apóstolos, sem entrar pela porta, trazendo-lhes a paz: “a paz esteja com vocês”! ${ }^{853}$ Logo, mostra-se Sua Majestade à alma em Sua Sagrada Humanidade, em grande esplendor e formosura, como depois de ressuscitado ${ }^{854}$ e lhe diz: "olha este cravo, que é sinal que serás minha esposa, desde hoje. Até agora não o havias merecido. Daqui em diante, não só como Criador e como Rei e teu Deus, olharás minha honra, senão como verdadeira esposa minha. Minha honra é tua e a tua é minha" ${ }^{855}$ !

É um segredo tão grande e uma mercê tão elevada o que ali Deus comunica à pessoa. Ela sente um grandíssimo deleite que não há com o que se comparar. E, de tal maneira se junta Deus à criatura, que já não pode apartar-se, porque Ele não

\footnotetext{
$8487 \mathrm{M} 1,1$.

${ }^{849}$ Cf. 7M1,3;9.

${ }^{850}$ Jo 14,$23 ; 7 \mathrm{M} 1,6$.

${ }^{851}$ Cf. $7 \mathrm{M} 1,7$.

${ }^{852}$ Cf. $7 \mathrm{M} 1,9$

853 Jo 20,19 .

${ }^{854}$ Cf. 7M2,1.

${ }^{855} 5 \mathrm{M} 1,12$.
} 
quer separar-se dela e, num instante, a alma se transforma e o espírito desta alma fica uma só coisa com Deus, que é Espírito ${ }^{856}$. Neste matrimônio espiritual realizam-se as palavras de São Paulo: "o que se eleva e se une a Deus, torna-se um espírito com Ele" ${ }^{\natural 57}$. Soberano matrimônio. Para quem aqui chega o certo é que o Rei já aproximou a alma junto de $\mathrm{Si}$, por meio da união espiritual profunda, a ponto da alma exclamar como o apóstolo: "para mim, viver é Cristo e morrer é lucro!" ${ }^{858}$ É então, que morre a mariposa de que se falou. E, morre com imensa felicidade e fecundidade, porque teceu sua vida em Cristo e sua Vida é Ele ${ }^{859}$.

A união das quintas moradas era semelhante à união de duas velas de cera, perfeitamente unidas, produzindo uma só chama. Ali era possível separar uma vela da outra, ficando duas velas. De modo que o Senhor unia a alma consigo na oração de união, mas a alma ainda não entrava em seu centro. Aqui, este matrimônio é semelhante à água do céu que cai sobre um rio, ou uma fonte, na qual ambos se unem totalmente, a ponto de não se distinguir mais a água do rio e a água caída do céu. Pode ser comparada ainda a um pequeno arroio que se lança ao mar, sem meio de separá-lo, ou, como um grande jato de água que não pode jorrar perto das pessoas, sem provir do manancial ${ }^{860}$. De modo semelhante, a alma entende claramente que dentro de si há Alguém que dá vida à sua vida e prorrompe: ó vida de minha vida! Oh, sustento que me sustenta! Brotam uns veios de leite dos peitos divinos, nos quais Deus parece estar sempre sustentando a alma. Este leite conforta e apazigua a todas as pessoas do castelo, porque o Senhor quer que todas as potências participem do muito que a alma está fruindo ${ }^{861}$.

Vê-se, então, que $\mathrm{O}$ esposo introduziu a Esposa à sua adega. Agora, já não quer deixá-la mais sair. Assim, as energias acumuladas pela alma ao beber o vinho, influem sobre a fraqueza natural e fortalecem o corpo, cessando os arroubamentos. Não falta cruz à alma, contudo nada mais consegue inquietá-la. Nada pode fazer-lhe perder a paz. As provações passam depressa. São como uma onda, ou certo aguaceiro em dia de tempestade, em seguida, tornam à bonança ${ }^{862}$.

\footnotetext{
${ }^{856}$ Cf. $7 \mathrm{M} 2,5$.

${ }^{857} 1 \mathrm{Cor} 6,17 ; 7 \mathrm{M} 2,5$.

${ }^{858}$ Fil 1,21.

${ }^{859}$ Cf. 7M2,6.

${ }^{860}$ Cf. $7 \mathrm{M} 2,4$

${ }^{861}$ Cf. 7M2,6.

${ }^{862}$ Cf. 7M 3,15.
} 
A presença do Senhor que traz consigo, a faz esquecer os tormentos passados. E pode haver muitas guerras no Reino, mas o Rei se mantém em paz no seu aposento e a alma, ali, com Ele, permanece serena, pois se encontra na morada da paz $^{863}$. Desta forma, entende tudo melhor, com o andar do tempo e por seus efeitos. Desapega-se de todas as realidades. Se o sofrimento faz parte da vida, sente desejo de padecer, se precisa ser perseguida enfrenta. Sabe que não foi para gozar que recebeu tantos favores, pois obras quer o Senhor ${ }^{864}$ ! E para isso, deseja trabalhar para o bem de todos e para que todos se salvem. Nas outras moradas vinha crescendo em seu zelo apostólico, agora, ficou bem mais fortalecida pela força divina. Está ciente de que ajudará as pessoas, não tanto pelos desejos formulados na oração, embora aproveite de todos eles, mas, sobretudo, por colocar em prática todo o bem que compreendeu. Esmera-se na sua vida de caridade, sobretudo com as pessoas com as quais convive, pois entende que, através dela, Deus também agirá é fará muito mais ${ }^{865}$. Por sua vida, mortificação e por seu desejo de servir a todos, torna-se, profeta, apóstola e pregadora. Recorda a visita do Senhor a Marta e Maria e tem consciência de que o Senhor necessita ser servido $^{866}$. Não dá para imaginar Maria sentada sempre aos pés de Jesus, se sua irmã não a ajudasse. Assim procura que sua solidariedade seja tão intensa com as pessoas e percebe que o essencial de sua alma jamais se move daquele aposento onde está o Rei, parecendo-lhe que a alma se divide em Marta e Maria. É Marta e ao mesmo tempo é Maria. Integra a contemplação à ação e, enquanto uma fica naquela doce quietude a Seu prazer, a outra está tão envolvida em trabalhos e ocupações que já não pode fazer-lhe companhia ${ }^{867}$. Por suas secretas aspirações conhece claramente o quanto Deus desperta sua alma. As atividades íntimas do Senhor são percebidas com grandíssima clareza ${ }^{868}$.

A água, o sinal, ou o sol, que do interior lhe dardeja é como Alguém que dá vida à sua vida. Em certos tempos, a pobre alma anda tão aniquilada ao receber tantas graças que teme que lhe aconteça como a uma embarcação que vai ao

\footnotetext{
${ }^{863}$ Cf. 7M2,11.

${ }^{864}$ Cf. 7M4,6.

${ }^{865}$ Cf. $7 \mathrm{M} 3,2$.

${ }^{866}$ Cf. $7 \mathrm{M} 4,13$.

${ }^{867}$ Cf. $7 \mathrm{M} 4,12-13$.

${ }^{868}$ Cf. $7 \mathrm{M} 3,8$.
} 
fundo, por excesso de carga ${ }^{869}$. Nestas grandezas divinas conheceu melhor suas misérias, a ponto de, como o publicano, não ousar levantar os olhos. A humildade é o sólido fundamento deste edifício. Se não fosse verdadeira, o Senhor não a levantaria tão alto. E tudo isso se faz num grande silêncio, sem alarde, como a construção do templo de Salomão. Nesse templo de Deus, nesta morada sua, Ele e a alma se rejubilam em altíssimo silêncio. Aqui, a pomba enviada por Noé para ver se o dilúvio era fundo, colhe um ramo de oliveira, como sinal de que achou terra firme, por entre as ondas e tormentas deste mundo ${ }^{870}$.

Oh! Jesus! Quem saiba as muitas coisas da Escritura, que dão a entender essa paz da alma! Deus meu! Como vedes a grande importância disso, fazei que os cristãos a queiram buscar. Aqueles a quem já a concedestes não a tireis, por vossa misericórdia ${ }^{871}$.

Seu espírito verdadeiro faz-se um só com esta água celestial e todos os efeitos Deus dá à alma quando a aproxima de Si, com o ósculo da paz. Aqui há muito a maravilhar-se $\mathrm{e}^{872}$. A alma está como a árvore que junto às águas correntes tem as mais vicejantes folhas e dá os mais abundantes frutos. Para crescer no relacionamento com Deus e com os irmãos é preciso assimilar o desafio:

Sabeis o que significa ser, de fato espiritual? É fazer-se escravo de Deus, marcado com o seu selo, o da cruz. Assim nos poderá vender como escravos de todo mundo, como Ele próprio foi. Com isso não nos injuria, mas nos concede imensa graça. Já lhe entregamos toda a nossa liberdade. Se não tiverdes essa determinação, não espereis grande benefício. Porque o fundamento de todo este edifício, como eu já disse, é a humildade. E se esta não for genuína, até para o vosso bem, o Senhor não desejará elevá-lo muito, a fim de que não desabe por terra $^{873}$.

"Ponde os olhos no crucificado e tudo parecerá pouco. Se Sua Majestade nos mostrou o seu Amor com tão espantosas obras e sofrimentos, ao dar-se por inteiro, como quereis contentá-lo só com palavras?"874. Ofereça interior e exteriormente ao Senhor o sacrifício que estiver em suas mãos. Cristo o juntará com a oblação que fez de si mesmo, ao Pai, na cruz, por todos, e conferirá o valor

\footnotetext{
${ }^{869}$ Cf. $7 \mathrm{M} 3,14$

${ }^{870}$ Cf. $7 \mathrm{M} 3,11$.

$8717 \mathrm{M} 3,13$.

${ }^{872}$ Cf. $7 \mathrm{M} 3,9$.

${ }^{873} 7 \mathrm{M} 4,8$.

${ }^{874}$ Idem.
} 
merecido pelo amor e pela boa vontade, ainda que as obras sejam pequenas. Seja Deus Nosso Senhor bendito e louvado para sempre ${ }^{875}$ Amém! Amém!

É muito importante não retroceder no amor e lembrar-se de que o Senhor não olha a grandeza das obras, mas o amor com que elas são realizadas. É preciso perseverar neste amor de Deus e dos irmãos, louvando muito ao Senhor ${ }^{876}$. É importante viver plenamente a vida batismal, a vida da graça que Deus, desde toda a eternidade, reservou para seus filhos. Quando a pessoa se der conta de sua fraqueza é necessário extrair dela a força e procurar não perder, por culpa própria, uma só ocasião de agradar ao Senhor ${ }^{877}$ evitando qualquer ofensa a Deus. É oportuno, também, acolher tudo o que sua Majestade faz como bom ${ }^{878}$ e servi-lo em tudo ${ }^{879}$. Importa alegrar-se quando perseguida por alguém ${ }^{880}$ e mostrar um estranho esquecimento de si, dando a própria vida, de bom grado, para aumentar, mesmo que um pouco só, vida aos irmãos, a honra e a glória de Deus ${ }^{881}$. É bom não se descuidar e trazer a todos em suas orações, com particular cuidado em suplicar a Deus, especialmente pelos que estão no pecado, pois são como um cristão amarrado a um poste, com as mãos atadas atrás das costas por uma forte cadeia, morrendo de fome. Não por falta de comida, pois tem junto de si delicadíssimos manjares, mas porque, não podendo alcançá-los para levá-los à boca, sente grande fastio e vê que não tarda a expirar e a ser levado pela morte eterna. Não seria grande crueldade de nossa parte olhar para ele e não the aproximar da boca algo de comer? E, que seria se, por vossas orações, the caíssem das mãos as cadeias? Bem vedes a importância de fazê-lo. Pelo amor de Deus vos peço que vos lembreis sempre dessas almas em vossas orações ${ }^{882}$.

Em síntese, como conclusão do capítulo, o Castelo Interior é onde Teresa descreve as características e o desenvolvimento da própria personalidade cristã. As moradas são os diferentes graus do relacionamento com Deus, com o próximo e com toda a natureza criada. À medida que a pessoa adentra ao castelo e envolvese nesse relacionamento amoroso com Deus, deixa morrer o verme do seu egocentrismo e liberta-se ao serviço do Senhor e dos irmãos. À semelhança da

\footnotetext{
${ }^{875}$ Cf. $7 \mathrm{M} 3,8$.

${ }^{876} \mathrm{Cf} .7 \mathrm{M} 3,6$.

${ }^{877}$ Cf. $7 \mathrm{M} 3,14$.

${ }^{878}$ Cf. $7 \mathrm{M} \mathrm{3,3.}$

${ }^{879}$ Cf. $7 \mathrm{M} 2,7$.

${ }^{880}$ Cf. $7 \mathrm{M} 3,5$.

${ }^{881}$ Cf. 7M 3,2.

${ }^{882} 7 \mathrm{M} 1,4$.
} 
humanidade de Cristo e no Espírito Santo, a pessoa cresce em amizade e amor e "em graça diante de Deus e dos homens"

O desenvolvimento humano e espiritual a partir de Teresa e de seu castelo se dá da seguinte forma: nas primeiras moradas Teresa acentua a importância do autoconhecimento e do conhecimento de Deus, indispensável para o relacionamento entre o divino e o humano, encontra-se ainda "fora de seu castelo" alienado, na superfície. Nas segundas moradas, quando a oração já está iniciada, mostra-se a intensa perseverança na luta e o desejo de prosseguir no caminho de Deus e na via da troca com os irmãos. Nas terceiras, em geral, todos os cristãos estão nestas moradas. Também é onde a grande maioria permanece. Há virtude e incoerência. Nas quartas, há mescla de natural com sobrenatural e tentação porque o nível de comunicação com Deus é mais profundo e elevado, detestado pelo inimigo. Nas quintas, há profunda união com Deus, transfiguração nEle, um intenso processo de conversão, semelhante à transformação do bicho de seda. Nas sextas moradas, há grande purificação e efervescência de fenômenos místicos. As sétimas são a morada da paz. Em seu núcleo mais íntimo, é “onde se dão as coisas mais secretas entre Deus e a pessoa" ${ }^{\natural 84}$.

\section{5 \\ CONCLUSÃO}

O quinto capítulo fala da obra-prima de Teresa, da riqueza própria que deixa através de sua laborosa e saborosa redação. Nesta fica a compreensão da oração enquanto relacionamento de amizade pessoal com Cristo. Considerou-se aqui o Castelo Interior como uma obra surpreendente, sempre visitada e revisitada por muitos, inclusive como fonte para novos escritos, aberto às novas interpretações, estudadas e reinterpretadas em seus símbolos e significados. Por isso, torna-se obra digna de ser rememorada no quinto centenário do nascimento de Teresa.

Refletiu-se sobre as chaves de leituras para o entendimento dos símbolos teresianos e possíveis influências presentes na redação de Teresa, considerando as diversas relações estabelecidas pela monja, ao longo de sua vida: suas leituras, amizades, sua época e especialmente a influência das leituras cavaleirescas.

${ }^{883} \operatorname{Lc} 2,52$.

${ }^{884} 1 \mathrm{M} 1,3$ 
A força da mística teresiana, presente em todas as suas obras, mas de modo especial no Castelo Interior lembra que há em Teresa uma palavra viva, que provém da experiência de um amor generoso que se doa tanto a Deus quanto aos irmãos. Teresa abre as portas ao conhecimento humano e espiritual e à peregrinação ao leitor. É, com certeza, a partir desta sua experiência pessoal, que consegue compreender, dar sentido e dar a entender, de forma clara, o processo de evolução espiritual, disponível ao humano. Seu próprio crescimento e avanço na via da interioridade é segurança ao que se sente chamado a se desenvolver espiritualmente e a peregrinar nas diferentes moradas, pois tem uma mestra em quem confiar, que conhece a via, suas curvas, seus atalhos, seus trilhos difícieis.

A compreensão da oração, enquanto relacionamento de amizade com Deus, recebida de Teresa de Ávila, é uma dadiva para o cristão. A iniciativa dessa interrelação é divina, mas conta com o humano sempre e deseja elevá-lo. O percurso nas diferentes moradas deixa o claro entendimento de que Deus é fiel, que atrai a pessoa ao mais interior de si mesmo e que é irreversível em seu amor. O Senhor prova com obras seu amor, sua amizade, é apaixonado por seus filhos, irreversível em sua determinação de amor. Através de tudo o que faz e orienta, da graça, da ação de seu Espírito Santo conduz a pessoa à unidade com Ele, com o universo e à felicidade. Em Cristo, todos são filhos de Deus e a relação com a Trindade se dá nesta nova aliança com Jesus.

Outro aspecto a destacar no capítulo é que, na descrição das diversas etapas do Castelo Interior a sensibilidade e a escuta de Teresa propõem uma dinâmica crescente, a partir do símbolo do castelo, da luta para avançar e do matrimônio espiritual. Estes representam a interioridade da pessoa com sua realidade pessoal à luz daquilo que lhe dá sentido e do que pode ser claridade à sua vida. Chamada à interioridade e à profundidade da vivência do amor, volta-se à transcendência de si, tanto em direção a Deus, como em direção aos irmãos. Conectando-se com o núcleo mais profundo de si mesmo, num grau progressivo amplia sua consciência e responsabilidade de empenho na evolução humana e espiritual.

Desta forma, a proposta de oração, de relacionamento com Deus, como possibilidade de transformação pessoal e da sociedade é a proposta ao homem e à mulher do tempo de Teresa e ao homem e à mulher de hoje, pós-modernos. Sua via é um caminho de esperança, de interiorização e de escuta dessa Presença de Deus que está no interior de cada um e com a qual se pode dialogar 
constantemente desde uma realidade mais profunda. É preciso como Teresa, dar tempo a Deus, saber abrir-se e saber "ouvir" esta presença. O diálogo, a intimidade e a convivência com Cristo e com os irmãos possibilitarão um longo processo de transformação e de conversão. Pela imagem de Deus, dentro de si, a pessoa tem parâmetros para a sua conduta e é incentivada a deixar-se conduzir e transformar por Deus, como o bicho da seda se transforma na linda borboleta. Ao longo de seus passos e, através da contínua entrega à ação de seu Espírito entrará na dinâmica de constantes e progressivas mutações e, pela graça e pelo amor de Deus, se transcenderá.

Desta forma, é que Teresa mostra que a pessoa nasceu para "grandes coisas", que é "nascida para tais grandezas". Essa transformação pode se visualizar através da história pessoal de cada um. É uma transformação que se dá na ação do Espírito do Senhor e na graça que faz a pessoa sair de si mesma, não deixando-a alienada, mas inclinando a voltar-se aos irmãos, às necessidades deles e a envolver-se com questões importantes, que implicam transformação da história e da sociedade de seu tempo. "Obras" é o objetivo último de quem faz todo esse processo ao longo do castelo. Teresa expressa isso claramente: "Para isto é a oração filhas minhas, para isto serve o matrimônio espiritual: para que nasçam obras!” De modo que a oração desvinculada, desencarnada da vida não tem sentido algum.

A cada morada onde o cristão mais plenamente vive a unidade com Deus dá-se uma integração entre o ser, na inter-relação e no fazer humano. A culminância desse processo é sétima morada, um grau mais elevado de autoconsciência e de amor. O objetivo não é a pessoa ao orar tornar-se ativista, mas antes, ampliar sua consciência e grau amor realizando o que realiza, na graça e na força de um Deus que é presente, que age na história e, através de cada pessoa. Nota-se que o "Senhor não olha tanto a grandeza das obras, senão o amor com o qual são realizadas". Somente vivendo a inabilitação trinitária, se chega à plenitude da vida nova recebida na graça do batismo, onde é possível expressar: "Para mim viver é Cristo". Assim é que as pessoas tornam-se apóstolas, discípulas, profetas: na comunhão com Ele, doando-se completamente no serviço de Deus e dos irmãos. Este é o sentido de amar e de servir. 


\title{
6 \\ DESENVOLVIMENTO HUMANO E ESPIRITUAL A PARTIR DO CASTELO INTERIOR
}

\author{
6.1
}

Introdução

Ao longo do desenvolvimento, desta tese, pode-se perceber que o desejo de transcendência, da mística e do relacionamento com Deus são inerentes ao ser humano. Viu-se, num primeiro momento, Teresa em seu contexto de realidade. Num segundo momento o embate da ciência com a fé e a tentativa de diálogo, de ajustes entre uma e outra para compreender e integrar realidades distintas. Viu-se o olhar da psicologia para a mística de Teresa em seus primórdios e na atualidade. Por último, apresentou-se a mística teresiana, presente no Castelo Interior com a essência de seu pensamento, evidenciado na sua obra-prima. Viu-se, que para Teresa o primordial para a vida humana é amar ao Senhor e aos seus semelhantes.

Ao se olhar mais de perto, o desenvolvimento das diferentes moradas no Castelo de Teresa percebe-se que as mesmas não são outra coisa senão diferentes graus de amor com que a pessoa humana ama a Deus, aos irmãos e às irmãs. De modo que o que pretende afirmar-se nesta tese, ficando mais evidente, neste último capítulo, é que pode se visualizar na mística de Teresa, nas sequentes moradas do Castelo, esses diferentes graus de amor, com suas características humanas e espirituais específicas, como também, pode-se lhes atribuir um nome, que tenha correspondência ao que é mais peculiar em cada uma das fases em que a pessoa se encontra. Com isso, mostra-se aqui, que a mística de Teresa, do desenvolvimento humano e espiritual é também a mística do desenvolvimento do amor. O que Teresa repassou à humanidade como contribuição, pode ser uma alternativa, para a pessoa pós-moderna encontrar uma fonte de maior humanização e integração da vida, pois ao viver na intensidade mística, esse relacionamento de amizade e de amor com Deus, com os irmãos e com as irmãs, esse processo e projeto de humanizar-se torna-se mais pleno. Desta forma, a proposta teresiana de entregar-se ao processo de amar, quando vivido em seu comprometimento, com generosidade de coração, qualifica e transforma a vida, 
não somente da pessoa, como também do ambiente e da sociedade na qual se insere $^{885}$. "Óh! Grandeza de Deus! Quão transformada sai a alma daqui, depois de ter estado imersa na grandeza de Deus e tão unida a Ele" ${ }^{\text {} 886}$.

Parte-se aqui do embasamento e aprofundamento dos diversos estágios de evolução, segue-se pela via de Teresa apresentando os diferentes níveis de desenvolvimento humano e espiritual na sequência das sete moradas do Castelo Interior para compreender, por fim, que a vida só tem sentido, quando vivida no Amor $^{887}$. Pois o amor seguirá sempre sendo o sinal distintivo daquele que vive os ensinamentos de Jesus Cristo e quem os vive, permanece em Deus. À exemplo do Amor de Cristo pela Sua Igreja, a força do amor é o que dá sentido à vida.

Assim, a resposta e a oferta amorosa da existência ao Criador, pela total doação de si mesmo a Deus e ao próximo, pode ser contemplada em seu processo, na dimensão antropológica e religiosa do amor humano, desde o primeiro encontro e olhar, quando nasce a relação de amizade, até a sua consumação $e$ plenitude, que legitima a íntima união com Aquele que é o próprio “Amor” ${ }^{888}$.

\section{2}

\section{O amor em seus diferentes níveis}

Como não damos tudo de uma vez, também não recebemos de vez esse tesouro. Queira o Senhor que, gota a gota, Sua Majestade nos dê esse tesouro, mesmo que isso nos custe todos os sofrimentos do mundo ${ }^{889}$.

Ao expressar Teresa, na sua definição, que oração é um tratar de amizade com quem sabemos que nos ama ${ }^{890}$, a monja diz, em primeiro lugar, que a pessoa é amada por Deus. Para quem se dispõe ao caminho da mística, da oração, ser amado, ou amada por Deus é não só estar consciente da dádiva divina, reconhecendo-se agraciado(a) pela ternura do amor do Senhor, como também sente-se chamado(a) a corresponder a esse amor. Os que fazem a opção de adentrar a via do seguimento de Cristo são convidados a fazer da sua vida um

\footnotetext{
${ }^{885}$ Cf. C 4,2 .

$886 \mathrm{M} 2,7$.

${ }^{887}$ Também entre as modalidades do amor é "clássica e muito conhecida a distinção entre 'eros', 'philia e 'ágape". RUBIO, A. G. Nova Evangelização e maturidade afetiva. São Paulo: Paulinas, 1993. (Coleção estudos e debates latino-americanos). p. 106-107.

${ }^{888} 1 \mathrm{Jo} 4,8$.

${ }^{889} \mathrm{~V} 11,3$.

${ }^{890} \mathrm{~V} 8,5$.
} 
sinal para os irmãos e irmãs, o que evidencia de fato, que acolheram o dom do amor recebido de Deus.

Cristo, que caminha à frente de seus discípulos ${ }^{891}$, veio revelar o Pai e o seu grande amor pela humanidade. Um dia, ao ser questionado por um fariseu sobre qual o mais importante de todos os mandamentos, respondeu com toda a clareza e determinação: “Amarás o Senhor teu Deus com todo o teu coração, com toda a tua alma e com todo o teu entendimento" 892 . E acrescentou: "Esse é o maior e o primeiro mandamento. O segundo é semelhante a esse: amarás o teu próximo, como a ti mesmo. Destes dois mandamentos dependem toda a Lei e os profetas" ${ }^{\prime 893}$. Tal é a força de expressão do amor: essência constitucional da vida, que orienta e dignifica, a cada novo dia, os seres em direção ao seu projeto existencial e os santifica, uma vez que ser santo é realizar em plenitude o projeto que Deus propôs à vida de cada um.

É interessante notar nas palavras de Cristo, que Ele não só deseja que se faça a experiência do amor a Deus e aos irmãos, como também frisa: "Nisto, todos conhecerão que sois os meus discípulos, se vos amardes uns aos outros" Ou seja, pede que os que o seguem, vivam o mandamento do amor e, nisto, sejam suas testemunhas, "sendo para o mundo uma luz" 895 . E, àqueles que levam a sério a proposta sublime da vivência desse amor, Cristo pede ainda mais: amai-vos uns aos outros (não só: como a vós mesmos, mas:) como eu vos amei ${ }^{896}$. Assim, o cristão é interpelado a oferecer ao mundo a sua identidade (o Amor), de forma visível e distinta.

Portanto, acolher o amor de Deus e perseverar no amor de Cristo e no amor do próximo é exigência para o seguimento e união com Ele, ou seja, a lei básica do cristianismo. De maneira que, aos discípulos que se estreitam a Cristo para uma via de seguimento ainda mais próxima, a exigência do amor é, já desde o início de sua caminhada, reivindicação de disponibilidade, despojamento completo, gratuidade incondicional e total saída de si, para amar a todos como Ele os amou, em semelhante proporção, natureza e qualidade ao exemplo que deu.

\footnotetext{
891 Lc 9,28.

892 Mt 22, 34-40.

893 Idem.

894 Jo 13,35 .

${ }^{895}$ Jo 13,35 ; Mt 5,14 .

${ }^{896}$ Cf. Jo 15,12 .
} 
Deste modo, aos que desejam viver os ensinamentos de Jesus Cristo, há uma exigência de afeição fraterna, singular. Pode-se dizer: há a exigência de um grau de entrega ao amor ainda mais elevado, porque acolher o amor de Deus significa e implica: disposição do ser humano de permanecer em união vital com Ele, assemelhando-se a Ele, cristificando-se.

Pelo desmembrar da definição de oração teresiana, vê-se que quem adentra ao seu castelo interior, percebe-se olhado e amado por Deus: "Vede que o vosso Esposo nunca tira, filhas os olhos de vós" 897 e oração é "estar à sós, com Aquele que sabemos que nos ama" ${ }^{\$ 98}$. E, só pode entrar na dinâmica do relacionamento com Deus, aquele que deveras se sente olhado e amado por Deus. Por isso, Teresa também reconhece esse amor de Deus, descrito acima, como sinal distintivo do cristão e sugere, muitas vezes, em seus escritos, às pessoas de colocá-lo em obras $^{899}$. Propõe, a percepção de que acontece no espaço de maior intimidade onde preserva-se acesa a chama viva do amor de Deus ${ }^{900}$, de observar como esta irradia-se às ações humanas. É pelos frutos e não pelas consolações, possível distinguir o claro sinal claro de quem acolheu o amor de Deus: não são as lágrimas, as delícias e as ternuras da oração, mas o servir.

Sim, pois o amor de Deus não está em ter lágrimas, nem em ter esses gostos e essa ternura, que em geral desejamos e com os quais nos consolamos, mas em servir com justiça, força de ânimo e humildade. Isso me parece mais receber do que dar alguma coisa ${ }^{901}$.

Assim, o amor, embora gratuito, por sua natureza, convida à reciprocidade:

O amor, contudo, tem tamanha força, se for perfeito, que desprezamos nosso próprio contentamento para contentar aquele a quem amamos. E é isso, na verdade, o que acontece: por maiores que sejam os sofrimentos, logo se tornam suaves quando sabemos que, com eles, agradamos a Deus. Quem chegou a esse ponto, ama deste modo as perseguições, as desonras e as ofensas ${ }^{902}$.

Portanto, esta abordagem busca evidenciar como as pessoas amam, compreendendo que cada ser humano ama a partir das suas próprias condições e de sua realidade pessoal, situando-se em um nível de amor. Assim, ao avançar no

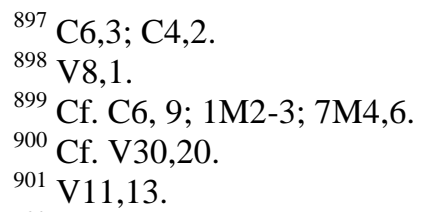

${ }^{902}$ SANTA TERESA DE JESUS. Fundações. In: SANTA TERESA DE JESUS. Obras Completas. Revisada e anotada por Frei Tomás de La Cruz. Coordenação Frei Patrício Sciadini. 2. ed. São Paulo: Loyola, 2002. (Abreviada por F). F 5,10. 
amor de Deus, pela via do relacionamento com Ele, necessariamente, o ser humano avança na transcendência de si, porque a oração $e$ o amor para Teresa, não são algo estanque, uma vez que amar também é uma forma de orar e de ser para Deus o louvor vivo de sua glória. O amor integra a vida e se integra nela, se coaduna com a existência e a transforma, porque "o essencial da oração não consiste em muito pensar, mas em muito amar" ${ }^{\text {,903. }}$

Joyce Ridick, em seu livro: Os votos, um tesouro em vasos de argila $^{904}$, falando sobre o amor, situa-o em três distintos níveis da vida psíquica, semelhantes aos de níveis de Cencini: nível psicofisiológico, nível psicossocial e nível espiritual-racional.Assim, para a autora, a pessoa naturalmente cresce no amor, adiantando-se em níveis distintos, que perpassam várias fases, desde a dependência absoluta do amor de outrem, à sua plena maturidade. Para ela, o amor mais elevado com que uma pessoa, ou Deus, podem ser amados é o amor espiritual. Alguém que ame com esta qualidade de amor, o faz porque está numa dimensão mais ampla, mais livre, mais autêntica, mais original, mais plena e mais próxima ao amor de Deus. Mas esse crescimento não é sequencial. Desta forma, é possível que alguma pessoa esteja num estágio mais avançado de amor, sem ter passado pelas demais etapas. Pode ter recebido alguma graça especial de Deus que "dá quando quer, a quem quer, não importando a antiguidade, ou os serviços prestados"905, como também o entende Teresa ${ }^{906}$. E isso, em função de algum desígnio do Senhor e para o bem de todos. Semelhante graça é a que Deus realizou em Maria, que recebeu uma condição de estar cheia de graça, plena do amor de Deus, preparando seu coração e sua vida para orientá-los totalmente a Jesus Cristo, seu Filho e à sua obra ${ }^{907}$.

Assim, para Ridick, o nível psicofisiológico é o que tem uma estrutura de funcionamento básica tanto para as pessoas como para os animais. É o amor 'carnal', amor de atração física, de simpatia, de desejo dos sentidos. E o individual aqui ganha força. Nesse nível, o diálogo, a comunicação com o meio se dá de forma espontânea, automática, não-reflexa, 'pré-consciente', por impulso

\footnotetext{
$9034 \mathrm{M} 1,7$.

${ }^{904}$ Obra: RIDICK, J. Os votos um tesouro em vasos de argila. Reflexões psicológico - espirituais. São Paulo: Paulinas, 1986.

${ }^{905} \mathrm{~V} 34,11$.

906 4M1,2.

${ }^{907}$ Cf. Lc 1,26-38.
} 
emotivo e estão sujeitos às mudanças e aos condicionamentos dos estímulosresposta. O corpo encontra-se, assim, na disposição de ativar e de facilitar a relação e a interação interpessoal. De modo que, em nível fisiológico, a pessoa humana sente necessidades afetivas, como: a de ser acolhido, corresponder a uma fascinação física, sensual, de simpatia, de estar com alguma pessoa, realizar, ou voltar a uma experiência que sentiu como prazerosa. O termo carnal é o que se aplica a este tipo de atração e de condição. Neste nível psico-fisiológico é onde o amor encontra-se da forma mais primitiva. Enquanto permanece no desejo, ou na busca imediata da satisfação das necessidades fisiológicas, dos sentidos. Condiciona e é condicionado pela situação de estímulo-resposta ${ }^{908}$. Também Rúbio percebe este amor carnal como amor de desejo. Assim:

O amor erótico, ou amor de desejo parte do sujeito e tem como objetivo a realização e a satisfação de tendências derivadas de necessidades do próprio sujeito. É o tipo de amor que a nossa tradição cultural atribui ao desejo sexual, mas não exclusivamente. Na realidade, o amor de desejo está presente, também nas relações entre todos os seres humanos e até na relação com Deus. Existe esta modalidade de amor sempre que o outro é procurado, amado, etc., na medida em que responde a determinadas tendências do sujeito. $\mathrm{O}$ que prevalece é a subjetividade do indivíduo, são as suas necessidades, enquanto que o resto tende a ser reduzido à categoria de objeto. É muito forte, neste tipo de amor, o perigo de coisificar e de instrumentalizar o outro ${ }^{909}$.

Já no segundo nível, no nível psicossocial, conforme RIDICK, o amor encontra-se numa dimensão mais objetiva. Neste nível já é fruto de opções e de atos voluntários, não mais simplesmente de estímulo físico, de atração, de reação corporal. Já é um nível de maiores trocas e o individual aqui, torna-se, limitado. A pessoa neste nível necessita, então, crescer mediante a interação com os demais. O estímulo se orienta em função daquilo que lhe é adequado, mas o centro da atenção desloca-se da própria pessoa para a outra. Passa-se aqui, da sensualidade à afetividade, da gratificação pessoal para a comunicação física e interpessoal, estabelecendo-se, com as pessoas, uma relação mais elevada de ser com o outro. Assim, passa-se, também, do nível da auto-preservação e da auto-satisfação, à auto-realização e auto-afirmação em cooperação com os demais. A pessoa, nesse nível, dispõe-se a dar e a receber. Agora já não mais unicamente num plano físico, mas na troca de idéias, de interesses, da visão de mundo, de sentimentos, de

${ }^{908}$ Cf. RIDICK, J. Os votos, um tesouro... p. 56-59.

${ }^{909}$ RUBIO, A. G. Nova Evangelização e maturidade afetiva... ... p. 106. 
sonhos, ideais. Aqui, busca-se a verdadeira benevolência para si e para o outro, de modo bem mais desinteressado que o primeiro nível. E a interação se dá através do reconhecimento mútuo e da reciprocidade em cuidados, afinidades, atenção, trabalhos, fins, numa comunicação realizada em outro plano, distinto do estágio anterior $^{910}$. Também para Rúbio esse amor já leva em conta o outro e é amor de amizade:

No amor de amizade, ou de 'philia', o outro é aceito e respeitado como outro. Trata-se do amor interpessoal, que valoriza as qualidade do outro, bem como as próprias, mas é capaz de ir além delas. É um amor que exige reciprocidade. [...]Neste tipo de amor, o outro é respeitado como outro, mas ao mesmo tempo, as qualidades do outro suscitam o meu desejo, ou melhor, é a minha carência expressada no desejo que encontra resposta nas qualidades do outro. $\mathrm{O}$ que importa para que exista realmente o amor de amizade é que prevaleça o respeito à alteridade do outro sobre o desejo possessivo ${ }^{911}$.

E o terceiro nível, espiritual-racional para Ridick, já é o que ordena tanto a gratificação física do primeiro nível, como a auto-realização do segundo. Aqui, a pessoa abre-se, à transcendência, para fins que vão muito além de si mesmos e da inter-relação, para fins ainda mais altruístas, para Deus. Conforme a autora, este é o amor genuíno, generoso. Baseia-se na verdade e em necessidades inatas de pensar, julgar, avaliar, mas, sobretudo, de transcender os sentidos, sobreelevandose ao presente, imediato e material. É o nível em que se reflete sobre os fins e os meios para escolher livremente o que permanece, o que se eleva acima da carne e da paixão a um gênero ainda mais autêntico, mais idealista e pleno. Aqui o processo do dinamismo interior é mais que atração, mais que colaboração: é dom total, livre, incondicionado de si mesmo ao Criador e aos outros, no qual a pessoa chega a optar até por perder de vista o próprio ser, a existência, por outro bem considerado ainda mais precioso. É um amor raro, absoluto, extremo, autêntico, amadurecido, de total esquecimento de si, que ganha em unificação pessoal e integração em Deus. É o amor genuinamente cristão, subordinado aos ideais, à liberdade dos filhos de Deus, feitos à imagem e semelhança do Deus-Amor, que é plenamente indiviso e se fez sacrifício, holocausto ${ }^{912}$. Para Rúbio, este terceiro nível é nível do amor agápico.

Na perspectiva cristã, trata-se do amor com que Deus ama, ou melhor, o amor que é Deus mesmo (cf. 1Jo 4,8.16). Amor plenamente gratuito que se aproxima

\footnotetext{
${ }^{910}$ RUBIO, A. G. Nova Evangelização e maturidade afetiva... pp. 60-63.

911 Ibidem. p. 106.

${ }^{912}$ Cf. Ál VAREZ, A. S. Castillo Interior... p. 63-67.
} 
do outro, aceito, respeitado e amado por ele mesmo. O amor agápico faz com que Deus [...] torne possível o nosso enriquecimento $(2$ Cor 8,9$)$. É o amor que faz com que Jesus Cristo, existindo na condição divina, esvazie-se a si próprio, assumindo a condição humana de homem servidor (Fl 2,6ss) para possibilitar que o ser humano se torne filho de Deus ${ }^{913}$.

Desta forma, partindo desta conceituação de Ridick, complementada por Rúbio, é que se embasa para demonstrar, a partir de agora, o desenvolvimento humano e espiritual, ou os graus de amor, na obra e na perspectiva do Castelo Interior de Teresa de Ávila, porque a própria santa diz: "no céu, as moradas são conforme o amor" 914 .

\section{3}

\section{O amor na vida e perspectiva de Teresa}

Na vida e nos escritos de Santa Teresa o amor é um tema que se desdobra em dois aspectos fundamentais: a afetividade amorosa (experiência e pensamento) e o amor teologal, que nela adquire quilates especiais dentro da experiência mística. Um e outro muito vinculados entre $\mathrm{si}^{915}$.

Como pôde se perceber até aqui, o amor ocupa lugar central na psique de Teresa. Sua afetividade, rica de expressões, é primordialmente, antes de qualquer adjetivação, amorosa. Muito embora não usando a terminologia de Ridick e da Escola de Rulla, Teresa já falava sobre esses três níveis de amor que foram definidos pela autora. E o terceiro nível, compreendido por Joyce Ridick, como espiritual racional, Teresa o define como o amor virtuoso, amor espiritual:

Mas, quanto ao modo como haveremos de nos amar e quanto ao amor virtuoso - aquele que desejo ver aqui, - bem como no tocante a saber se temos essa virtude, que é muito grande, pois Nosso Senhor a recomendou tão encarecidamente a nós, e em particular aos Seus apóstolos[...]. Quero tratar de duas maneira de amor: uma espiritual, porque parece que nada tem com os sentidos nem com a ternura da nossa natureza, a ponto de ser privada de sua pureza; a outra também é espiritual[...]. Do que é espiritual, no qual não intervém nenhuma paixão, quero falar agora, porque quando há paixão, a harmonia se perde[.... $]^{916}$.

Conforme Teresa, esse é o amor virtuoso, em sua genuína expressão. Antes de tudo, desinteressado, livre de egoísmo, que se demonstra através das obras e

\footnotetext{
${ }^{913}$ RUBIO, A. G. Nova Evangelização e maturidade afetiva... p. 106-107.

${ }^{914} \mathrm{~F} 14,5$.

915 ÁlVAREZ, T. Diccionario de Santa Teresa. Doctrina e Historia. Burgos: Monte Carmelo, 2002. p. 46.

${ }^{916} \mathrm{C} 4,11-12$.
} 
não só com sentimentos. É um amor que transcende tudo e é precioso, pois “imita o capitão do amor, Jesus, nosso bem"917. Esse amor se alegra com as alegrias dos irmãos e se enternece com os sofrimentos dos outros. Quem "recebe favores de Deus e verdadeiramente o ama, não deixará de alegrar-se com quem O deseja servir" ${ }^{\prime 918}$. Este grau de amor não está embasado na mera aparência de beleza e na simpatia (psicofisiológico), mas em valores consistentes, capazes de eternidade "essa pessoa ama de um modo deveras, distinto daquele de quem não chegou a esse ponto" "19. Às jovens aprendizes do Caminho, propõe já desde o primeiro momento o ideal do cristianismo, o ideal do amor virtuoso, puramente espiritual, esboçando-lhes a silhueta do verdadeiro amante ${ }^{920}$.

Voltemos agora ao amor que devemos ter umas pelas outras, aquele que falei ser puramente espiritual[...]. Parece-me que a pessoa a quem Deus leva ao claro conhecimento do que é e de como é o mundo e de muitas coisas que o Senhor ensina a quem se deixa instruir por Ele na oração, ou a quem Ele deseja instruir[...]. Essas pessoas são almas generosas e régias que não se contentam em amar algo tão ruim quanto o corpo, por mais belo que seja, e por mais gracioso, mas que embora o admirem, louvando o Senhor por isso, não se detêm nele a ponto de admirá-lo por seus atrativos exteriores ${ }^{921}$.

Assim, na pedagogia de Teresa, quem ama com amor virtuoso faz parte de um processo onde desenvolve-se no amor com a meta de chegar ao amor elevado, ao amor de total entrega e transcendência de $s i^{922}$ "e a quem o Senhor tiver dado o amor puro espiritual, louve-o muito porque deve ser de grandíssima perfeição" 923 . Insiste no aspecto da interação e doação humanas e prefere que seus filhos e filhas mais se amem ternamente e com regalo, ainda que o amor não seja tão perfeito, do que haver um só ponto de discórdia. A discórdia e o desamor equivaleriam a expulsar de casa o Esposo, ou a frustrar a dimensão vertical do amor, tão necessária para o seguimento de Cristo. Assim, subentende-se em $o$ nível da satisfação dos sentidos (psicofisiológico) e a reciprocidade em vista do bem do outro (psicossocial). Desta forma Teresa orienta suas filhas a um nível mais elevado de entrega de si mesmas (espiritual-racional), ao introduzir a noção de Cristo, sua Casa e da necessidade de agradar ao Esposo no apelo que lhes faz

${ }^{917}$ C6,9.

${ }^{918}$ Cta. 239; C 7,6-7.

919 C6, 3.

${ }_{920}$ Cf. $4 \mathrm{M} 1,7$.

${ }^{921} \mathrm{C} 6,1-4$.

922 Cf. C6.

${ }^{923} \mathrm{C} 6,1$. 
de oblação total a Deus na vida contemplativa ${ }^{924}$. Às suas filhas refere que se é o Deus Amigo e o Amor que as chama e as reúne nessa Casa $^{925}$, para oferecerem a oblação de suas existências e viverem como esposas $\operatorname{suas}^{926}$, na contemplação e na intimidade com o Senhor, acompanhando os passos de sua humanidade, que deverão derramar-se também como o Amor se derramou para elas e para todos ${ }^{927}$.

Crede-me[...] a quem o Senhor tiver escolhido particularmente para aqui, vejo que lhe faz esta mercê[...]. Esta Casa, é um Céu, se o pode haver nesta Terra, para quem se contenta só de contentar a Deus e não faz caso do seu próprio contentamento $^{928}$.

Assim a mística do amor transforma a vida de quem é amigo(a) de Cristo e se encontra em união com Ele. Transforma-se em amor abnegado de si, derramado ao serviço de Deus e dos irmãos. Pois os que resolvem caminhar pela vias do relacionamento com Deus são "servos do amor",929, e o amor tem exigências que o mais austero espírito de penitência jamais atingiria. Ele exige não apenas "muito", mas exige "tudo" e "chega-se muito tarde ao perfeito amor de Deus, porque as pessoas tardam a se entregar inteiramente ao Senhor", não sendo capazes de esquecer-se de si mesmas ${ }^{930}$. Assim, para Teresa o amor alcança sua plenitude ao implicar transcendência de si, no amor ao próximo e a Deus ${ }^{931}$.

Num mundo marcado pelo ódio e pela violência, o amor virtuoso, espiritual tanto na comunidade contemplativa, como ao que opta pelo caminho da mística, torna-se o autêntico apostolado do amor e, segundo Teresa, "Isto será alcançar almas a Deus, específico apostolado da alma contemplativa"932. Aos que se abrem à graça e à Ação do Espírito Santo entregando-se a esse relacionamento com Deus, desenvolvem, sua capacidade de amar e vão construindo a partir de seu "castelo interior", sua personalidade cristã, sob o sólido alicerce da Vida de Cristo doada inteiramente ao bem de todos.

\footnotetext{
924 Cf. C4-7.

${ }^{925}$ Cf. C13, 6-7. "Ó irmãs minhas em Cristo! Ajudai-me a suplicar isto ao Senhor, que para isto vos juntou Ele aqui. Esta é a vossa vocação" C1, 5 .

926 Teresa retira da simbologia do matrimônio espiritual o conceito de esponsabilidade com o Senhor e relata a partir de sua própria experiência mística: Ver: R38.

927 "O amor de Deus foi derramado em nossos corações pelo Espírito Santo que nos foi dado". Rom 5,5.

${ }^{928} \mathrm{C} 13,7$.

${ }^{929} \mathrm{~V} 11,1$.

${ }^{930} \mathrm{~V} 2,1 ; \mathrm{C} 12,2$.

${ }_{931}$ Cf. 5M3, 9.

932 7M,4-14.
} 


\section{4}

\section{Fases do desenvolvimento no Castelo Interior}

A partir daqui serão descritas as fases referentes a presente tese.

\subsection{1}

\section{Fase da inconsciência}

Este amor benévolo de amizade pode também transformar-se em 'amor louco', como o chama Maritain: transcendência de si, a ponto de dar livremente tudo o que sou e não simplesmente o que tenho, ou faço, ao outro [...]. Enquanto cristãos somos 'capazes de autotranscendência responsável pelos outros não somente enquanto cidadãos desta Terra, mas como peregrinos com destino à cidade eterna ${ }^{933}$.

Aqui, para se compreender a expressão simbólica do encontro à amizade espiritual é importante ter presente duas palavras-chaves: consciente $e$ inconsciente. Cencini e Manenti partem de raízes junguianas e do conceito de Lonergan de que entre consciente e inconsciente existe uma zona de sombra:

Para visualizar a sombra consciente-inconsciente podemos usar a metáfora que Lonergan aplica ao problema da liberdade e responsabilidade: 'se se apresentasse o campo da liberdade do homem como uma área circular, então poder-se-ia distinguir uma região central luminosa na qual ele é efetivamente livre, uma penumbra circunstante na qual a sua consciência inquieta continua a sugerir-lhe que poderia fazer melhor apenas se quisesse se decidir e, por último, uma sombra externa da qual apenas se dá conta' ${ }^{934}$.

Deste conceito psicológico extrai-se o conceito espiritual para fundamentar a simbologia de Teresa. Lonergan considera que há uma região central luminosa, de onde provém a vontade consciente e deliberada e percebe a sombra externa como representação do inconsciente e a penumbra intermediária como o lugar da sombra, ou intercâmbio entre consciente e inconsciente ${ }^{935}$. De semelhante modo, é interpretada, aqui, a simbologia de Teresa que afirma ser a morada central do castelo interior, onde reside o próprio "Sol", a morada da luz ${ }^{936}$ e que, na exterioridade do castelo situa-se o afastamento de Deus ${ }^{937}$. Entende-se, então, que Teresa estabelece a presença de um consciente e um inconsciente espiritual.

\footnotetext{
${ }^{933}$ RIDICK. J. Os votos, um tesouro... p. 71-72.

${ }^{934}$ CENCINI, A.; MANENTI, A. Psicologia e Formação: Estruturas e Dinamismos. São Paulo: Paulinas, 1988. p. 228.

935 Idem.

$9361 \mathrm{M} 2,1$.

${ }^{937}$ Cf. $1 \mathrm{M} 2,2$.
} 
Assim, quanto mais próximo desse centro de luz, há maior liberdade, há maior união com Deus, maior consciência espiritual, maior refinamento e sensibilidade espirituais e, quanto mais distante, maior a inconsciência espiritual, a insensibilidade, a rudeza e o afastamento de Deus.

Por isso, nos animais: cobras, víboras, parasitas, sapos que se encontram nas primeiras moradas, Santa Teresa externaliza aquilo o que é prejudicial à pessoa, enquanto ser espiritual e humana, pois já se viu aqui, que se a pessoa é realmente espiritual, tanto mais humana ela é. Assim, sendo humana e espiriritual, como diz Teresa, a pessoa é "nascida para Deus e para as suas grandezas" $" 938$. Os animais representam o rastejar baixo, quando a pessoa é chamada às coisas tão altas e sublimes. Desta forma, nas zonas mais interiores do castelo, para o sujeito humano-espiritual, prevalecerão as ações mais sintonizadas e harmonizadas com a proposta de Deus para com ele, enquanto que nas zonas mais externas do castelo, da exterioridade da pessoa, prevalecerão as ações mais inconscientes e dissonantes ao plano divino. O indivíduo, na situação de distanciamento de Deus não consegue pensar-se como sujeito humano-espiritual, como alguém capaz de amar a Deus e aos irmãos com opção, determinação e consciência reflexiva e ligar-se à uma condição de quem se une à fonte da vida, à fonte de um Bem maior, à transcendência voltada para um sentido e universo mais amplo.

De modo que, o fato desses animais, inconvenientes e perniciosos conviverem com ela, domiciliarmente, estando dentro de sua casa, de seu precioso palácio, não somente representam a inconsciência de ser o que se é, de poder reconhecer-se como sujeito, como também esses elementos inconscientes "podem limitar o exercício efetivo da liberdade ontológica, impedindo a pessoa de utilizar profundamente aquilo de que dispõe" ${ }^{\text {"939 }}$. Por isso, Teresa diz que as pessoas das primeiras moradas estão como que paralisadas, atadas, cegas e são como estátuas de $s a l^{940}$, não conseguem fazer uso adequado de suas potências. Paralisam-se e não conseguem avançar no caminho. De modo que, no relacionamento com Deus e no relacionamento com os irmãos e irmãs, as pessoas das primeiras moradas são consideradas, aqui, num primeiro nível de

\footnotetext{
${ }^{938} 5 \mathrm{M} 2,13$.

${ }^{939}$ Cf. CENCINI A.; MANENTI, A. Psicologia e Formação... p. 228.

${ }^{940}$ Cf. 1M1,6.
} 
desenvolvimento humano e espiritual de relacionamento com Deus e com os irmãos, pois se encontram, praticamente, sem comunicação e relacionamento ${ }^{941}$.

Por estarem demasiadamente "fora de si mesmas", praticamente inconscientes de seu existir, ainda não estão fortalecidas, por isso agarram-se e prendem-se às coisas terrenas, aos bens materiais, a materialidade da vida, mostrando-se impossibilitadas de um encontro mais profundo com Deus e com os irmãos, com maior amplidão de trocas. Tem um movimento, em direção ao transcendente e ao imanente, ainda bastante frágil. Ou seja: por encontrarem-se, num nível de desenvolvimento de inconsciência ante a grandeza divina que comportam em si mesmas, não podem valorizá-la e também não se autovalorizam, tendendo a identificar-se com pseudovalores ${ }^{942}$. Para Cencini e Manenti pseudovalores, significam valores sem maiores consistências.

Os valores são ideais duradouros e abstratos que se referem tanto à conduta atual como ao objetivo final da existência. Enquanto ideais duradouros diferenciam-se dos simples interesses[...]. Enquanto ideais abstratos, diferenciam-se das normas, já que não dizem imediatamente 'que' fazer, mas 'como' ser: não um comportamento, mas um estilo de vida ${ }^{943}$.

É interessante notar que "para introduzir o leitor neste tratado de vida espiritual, ou de teologia espiritual, Teresa começa falando da pessoa, da sua alma" ${ }^{944}$ pois quando desconhecem a riqueza de seu interior e desconhecem-se a si mesmas, enquanto personalidades espirituais, desconhecem sua própria beleza e buscam fora de si o que está em sua interioridade, aí processam suas ações distantes do núcleo interior, em um nível muito primário e de superficialidade, num nível de robotização, que Teresa expressa como paralisia, cegueira.

Para Alfonso Garcia Rúbio, a robotização tem um significado específico ${ }^{945}$.

A robotização do ser humano é uma ameaça que vem preocupando a muitos, já faz várias décadas, diante do predomínio da razão instrumental, no mundo da modernidade. Convém prestar atenção à advertência da psicanálise: desconectado da vitalidade do inconsciente, o ser humano corre o risco de ficar gravemente empobrecido e mutilado ${ }^{946}$.

\footnotetext{
$9415 \mathrm{M} \mathrm{3,2.}$

942 7M 4,2; CENCINI; MANENTI... p. 103.

943 Idem.

${ }^{944}$ ALVAREZ, T. Comentários a las Obras... p. 554.

${ }_{945}$ RUBIO, A. G. Nova Evangelização e maturidade afetiva... p. 49.

946 Idem.
} 
Assim, os animais peçonhentos de que Teresa fala, representam o veneno, ou seja, a dificuldade da pessoa de libertar-se ao que a amarra. Em outras palavras, são afeições desordenadas que prendem o ser humano à materialidade tornando-se para ele impedimentos ao seu crescimento, que como cisco em seus olhos espirituais impedem-no de ver a luz do Sol. Porque, os animais, com seus atrativos ilusórios, fazem a pessoa pousar neles o seu olhar, e, olhando para eles, a pessoa refugia-se numa zona de sombra, de superficialidades e de aparências, ao mesmo tempo em que foge de si mesmo e do apelo da luz maior de sua interioridade que a levaria à sua individuação conforme se viu na teoria junguiana e um avanço maior, a uma íntima união com Cristo no serviço aos irmãos. Assim:

Enfermos, vitimas de certa atrofia espiritual, necessitaremos da graça de Jesus para começar a andar e passar essa sutil barreira que faz de diagrama entre a esfera de sentido e o mundo do espírito. Ou para afastar o olhar nefasto das cidades, ou para recuperar a luz dos olhos e começar a ver ${ }^{947}$.

Deste modo, avançar às zonas mais interiores seria ir ao encontro do Sol divino, do self junguiano, ou "encontrar-se com o Deus dentro de si" Deus não é alguém situado no mesmo plano humano, "mas é a verdadeira origem do seu ser, mais próximo e íntimo a ele, do que o ser humano em si próprio"949 e "é o hóspede da alma em graça" $"$ ". Adentrar-se ao castelo significa acolher este hóspede e dispor-se à amizade e ao relacionamento com Ele.

Ora, toda a amizade nasce a partir de um primeiro encontro, de um primeiro olhar. Deste modo, a pessoa desta fase, como define Teresa, na primeira morada, situada em meio à superficialidade de sua vida, em dado momento, dá-se conta da sua interioridade, da presença de Deus e direciona a Ele o seu olhar. Não tem condições, até então, de reflexão e decisão consciente para optar por essa amizade, pois o discernimento religioso, a capacidade livre para essa opção, como diz Teresa é "própria das moradas mais elevadas" $" 951$. Nesta primeira fase, ainda se depara com inadequação de seus impulsos ${ }^{952}$ psicofisiológicos ${ }^{953}$ (de fome, sexo,

\footnotetext{
947 ALVAREZ, T. Comentarios a las obras... p. 559.

948 Idem.

${ }^{949}$ Cf. LAFRANCE, Jean. Reza ao Pai em teu íntimo. São Paulo: Loyola, 1995. p. 25.

${ }^{950} \mathrm{C} 28,1 \mathrm{ss}$

$9517 \mathrm{M} 1,3$.

952 Por impulso compreende-se "uma disposição para agir de modo a diminuir um acúmulo de tensão causado pela evolução de pulsões instintivas, ou pela redução das defesas do ego contra elas. Um impulso freqüentemente possui as qualidades de pressa, falta de deliberação e
} 
medo, raiva...) e lida fortemente com a defesa inconsciente, realizando o que faz, mais movida pela força do impulso inconsciente, do que propriamente por uma escolha reflexa e pessoal ${ }^{954}$.

E, nesse primeiro encontro, muito embora o olhar do ser humano à Deus não tenha ainda a expressão de confiança e a percepção dos amigos que já há muito se conhecem e se amam, tem a impressão do impacto, do sentir-se tocado, da surpresa e da admiração de um primeiro momento, quando o olhar atento acompanha o movimento do outro e por ele se interessa. Assim é que a proximidade desse encontro se dá mais pela via inconsciente, ou semi-consciente.

Contudo, neste frágil nível de consciência que tem, pode vislumbrar com suavidade o rosto de Deus, ao descobrí-Lo no olhar que Ele lhe dirige. E aí, nasce a relação de amizade entre as duas pessoas que se olham nos olhos ${ }^{955}$. É um olhar ainda um tanto descomprometido da parte humana, mas que poderá mobilizar suas energias internas para um maior comprometimento pessoal e maior desenvolvimento do amor. E, da parte de Deus, ao contrário, é um olhar comprometido, de quem sempre esteve, está e estará interessado no bem maior daquele ser que ama e por quem dá a vida para melhor compartilhar de tudo o que tem a lhe oferecer. De modo que "o que os olhos não viram, os ouvidos não ouviram e o coração do homem não percebeu, isto Deus preparou para aqueles que o amam"956. E é assim que, a partir desse primeiro olhar, ao sentir-se tocada pela graça divina, a pessoa começa a desenvolver sua relação de amizade com Deus, agraciada com a oportunidade de aceitar o seu dom de amor, convidada a deixar a vida ímpia e a orientar-se, definitivamente, num contínuo processo de

impetuosidade". KAPLAN, H. I.; SADOCK, B. J. Compêndio de Psiquiatria. Porto Alegre: Artes Médicas, 1990. p. 421.

${ }_{953}$ Por impulsos psicofisiológicos compreendem-se "as atividades psíquicas, estreitamente ligadas aos estados físicos de bem-estar ou mal-estar, determinados pela satisfação, ou não de necessidades fisiológicas fundamentais do organismo, como a fome, a sede, o sono, a sobrevivência, o estar com saúde...”. CENCINI, A.; MANENTI, A. Psicologia e Formação... p. 14.

954 “A personalidade pode organizar-se em torno de um sistema de defesas, algumas mais centrais e outras mais periféricas. Aquelas mais centrais servem para defender-se de um conflito. Aquelas mais periféricas servem para negar a nós mesmos o uso das primeiras. Uma rede de defesas, onde uma serve para defender-se de uma outra precedentemente colocada[...]. Não é sempre possível colocar uma demarcação clara entre os diversos níveis de defesa; todavia, quando se organizam desse modo, os níveis mais centrais são inconscientes e automáticos e os níveis mais periféricos (defesa da defesa) são mais pré-conscientes, ou mesmo conscientes e voluntários”. Idem. p. 301.

${ }_{955}$ Cf. LAFRANCE, J. Reza ao Pai em teu íntimo... p. 28.

${ }^{956} 1$ Cor 2,9 . 
conversão, à fonte da vida, porque manter-se na obscuridade espiritual seria o contrário da vida em plenitude. Assim:

És ímpio quando pretendes realizar-te fora de Deus, ou quando recusas aceitarte como dom de Deus, ou responder ao seu chamamento criador. Não deixas de ser pessoa livre, mas entras em contradição com o próprio ser e se essa recusa se eternizasse, seria o inferno ${ }^{957}$.

Assim entende Teresa este Castelo. Não como castelo encantado, mas "como símbolo da interioridade humana, da luta para realizar-se e de sua chamada a interioridade" 958 . Por processar-se ainda o relacionamento com Deus e com os irmãos, entre as luzes e as sombras do insconciente, pode-se dar a esse processo o nome de: Fase da inconsciência.

\section{4 .2}

\section{Fase da inconsistência}

Beija-me com beijos de tua boca! Teus amores são melhores do que o vinho[...] exultemos! Alegremo-nos em ti! Mais que o vinho celebremos teus amores! Com razão se enamoram de ti[...]! ${ }^{959}$

Nesta segunda etapa, o termo essencial a ser desenvolvido é abertura ao outro. E, aqui, o “outro” a ser reconhecido é Deus, mas também os irmãos. É um nível mais avançado que o anterior aonde a pessoa já faz opções conscienciosas e estende em alguma direção concreta seu olhar de amor. Viu-se, nas segundas moradas, que "a alma, procura fugir das cobras das ocasiões de pecado", buscando orientar-se em direção a ouvir a voz do Senhor. É o apelo de Deus, à pessoa, apelo ao qual agora já está mais atenta, pois já consegue perceber que o "outro se comunica com ela" e já capta sua comunicação, embora, como diz Teresa, essa comunicação venha do externo, de modo que a voz do Senhor faz-se ouvir, a partir de fora, exteriormente, necessitando mediações visíveis e claras: através dos acontecimentos, de palavras de pessoas amigas, de leituras, ou de algo que vê, ouve, ou que seus sentidos percebem ${ }^{960}$. Ou seja: através destes chamamentos externos, apela-se à consciência da necessidade de desenvolver-se ainda mais humana e espiritualmente. Pode-se emergir com maior força, contudo,

${ }^{957}$ LAFRANCE, J. Reza ao Pai em teu íntimo... p. 26.

958 ALVAREZ, T. Comentarios a las obras... p. 571.

${ }^{959} \mathrm{Cta} 1,2 ; 1,4$; Cta $1,1-1,7$.

960 2M3. 
ainda não brotando do interior de si mesma, por isso a petição de Teresa em relação ao beijo de Deus, faz sentido ${ }^{961}$. Porque a pessoa percebe que o toque de amor de Deus pode levá-la a uma comunicação mais intima e profunda que lhe dê significado à vida. Assim, pede-se e deseja-se essa comunicação mais frente a frente, mais próxima, porque ainda não se conseguiu, nesta fase um relacionamento mais profundo de amizade com Deus. Esta comunicação se dá em três planos: na interioridade, na luta e na busca dessa comunhão com Deus ${ }^{962}$.

As segundas moradas são os aposentos dos que já começaram a ter oração e entenderam a grande importância de não permanecer nas primeiras moradas, mas que, em geral, não tem ainda determinação para deixar de estar nelas, porque não abandonam as ocasiões, o que é um grande perigo. Mas já é grande misericórdia que, mesmo por pouco tempo, procurem fugir das cobras e coisas peçonhentas e entendam que é bom deixá-las ${ }^{963}$.

A reflexão de quem se encontra nesta fase basea-se em apoios concretos, não tendo outros elementos e critérios para uma maior abstração, simbolização. Neste estágio de desenvolvimento do relacionamento com Deus e com os irmãos, conforme Teresa, a pessoa tão logo ouve o que Deus fala, perturba-se com muitas inquietações. Está declarada guerra à alma. Esses ruídos encobrem a beleza do chamamento divino e muitas vezes a afastam do caminho iniciado rumo à interioridade, trazendo-a, novamente, à exterioridade de si mesma ${ }^{964}$. A metáfora usada pela santa da declaração de guerra fala dos conflitos, mas, sobretudo, das resistências da pessoa para avançar humana e espiriritualmente.

Resistência é um termo cunhado por Freud que se compreendem de duas formas: resistência inconsciente e resistência consciente. Geralmente o termo é aplicado ao processo de avanço, ou não, na análise, ou autoanálise. Pode-se também aplicá-la a outras realidades que estejam em desenvolvimento e sejam escolhas na vida da pessoa. Aqui se explora a resistência inconsciente, enquanto aquela que traz em si um motivo inconsciente para existir, que tende a paralisar, ou travar a pessoa de avançar no processo de conhecimento e crescimento pessoal. Bloqueia o movimento que traz à consciência elementos compreendidos como prejudiciais e que paralisam a pessoa em seu desenvolvimento. Assim:

\footnotetext{
961 Segue Teresa comentando a petição: “Ó grande Deus e Senhor nosso, que sabedoria tão profunda! A Esposa bem podia dizer beije-me, concluindo o seu pedido com menos palavras, porque diz com o beijo da sua boca? Pois com certeza não há palavras em demasia[...] com qualquer amizade que estiveres com Deus ficareis muito ricas. CAD 1,10;1,12;2,16;2,21; 1M1,3. ${ }_{962}$ Cf. ALVAREZ, T. Comentários a las Obras... p. 571.

$9632 \mathrm{M} 1,2$.

964 M1,3.
} 
A resistência inconsciente origina-se dos próprios recalques. Tanto que toda resistência sistemática, seja na auto-análise, seja na vida, é sinal infalível de um recalque. De um problema que ainda está fumegando. A resistência é para o recalque o que a fumaça é para o fogo. Denuncia-9 ${ }^{965}$.

Já a resistência consciente fala das dificuldades de assumir-se, na prática, aquilo que se opta. Tem a ver com o superego, porque pode haver alguma razão ideológica, ou de outra natureza, a evidenciar que ainda não se acredita totalmente no que se escolheu. Também mostra o conflito da pessoa. Geralmente, tanto na resistência consciente, como na resistência inconsciente a pessoa procura proteger-se, sobretudo, por temer a perda de algo que lhe parece conveniente, agradável, que a pessoa entende como ganho secundário, ou seja, aquele que não está diretamente relacionado à sua meta, aos seus objetivos. O que foge aos elementos essências do processo de individuação, na linguagem junguiana. Como se o processo de avanço no crescimento pessoal pudesse trazer desafios que a pessoa não pudesse tolerar, neste caso qualquer tentativa que pareça à pessoa romper com o sistema de defesa do ego, produz-lhe ansiedade (sensação que o indivíduo procura sempre evitar (princípio do prazer) ${ }^{966}$.

Por isso, neste nível, tanto ao se falar nos conflitos que a pessoa se depara como nas suas resistências, em semelhante sentido da Santa abulense, Khalil Gibran, também diz: "Vossa alma é muitas vezes um campo de batalha onde se degladiam vossa razão e julgamento com vossa paixão e vosso apetite"967. E, neste sentido, também Mohama, refere:

A resistência pode ser, portanto, um problema que nos force a decretar uma batalha, meus caros. Que decretemos! A luta, porém seja travada com paciência, tranquilamente. E com coragem. Não podemos a esta altura da vida recuar perante fantasmas [...]. Nossa felicidade [...] merece uma temporada de suor ${ }^{968}$.

Assim, aqui, na grande luta, o conflito da decisão pessoal, de optar, ou não, por um nível mais consciente de amor e dedicação à vida, aos irmãos e às coisas de Deus, são ainda maiores do que outras ebulições de situações mal elaboradas na vida daquele que está tentando encontrar-se e firmar-se nessa caminhada. Desta forma, as muitas dificuldades e resistências ao confronto humano e espiritual que a pessoa depara-se, revelam-lhe que, basicamente pode encontrar-se entre dois

\footnotetext{
${ }^{965}$ MOHAMA, J. Ajustamento conjugal. São Paulo: Loyola, 2004. p. 34.

${ }^{966}$ MOHAMA, J. Ajustamento conjugal... p. 35.

${ }^{967}$ GIBRAN, K. G. O profeta. Texto Integral. São Paulo: Martin Claret, 2003. p. 75.

${ }^{968}$ MOHAMA, J. Ajustamento conjugal... p. 35
} 
modos de existir: viver para Deus, com toda a significação de que esse "viver" comporta, entregando-se à doação da vida aos irmãos e irmãs, ou permanecer na superfície de si mesmo e na inconsciência do valor e sentido de vida.

Por isso essa fase é a que convoca a pessoa a uma forte tomada de consciência. Para avançar, precisa seguir reoptando e reafirmando-se em suas determinações, posicionamentos, decisões: se quer continuar a viver uma vida medíocre e em um nível humano e espiritual inconsciente, ou pré-consciente e frágil, sem um maior significado, num nível de relacionamento com Deus de ilusão, de inconseqüência, de ser levado pela vida, sem tomar-se adequada e apropriadamente em suas mãos. Ou ainda, sem aspirar a uma vida de maior qualidade, maior enlevo, onde possa refletir-se a si mesma, conhecer-se mais e orientar-se a um singular projeto de vida, enquanto sujeito da história e de seu próprio destino. Sua opção é o que poderá elevar seu nível de consciência e estabilizar um pouco mais suas inconsistências, pois "diz-lhe, ainda, o intelecto que, fora desse castelo, não encontrará segurança, nem paz, devendo abandonar as casas alheias, já que a sua própria casa está cheia de bens"969.

Acabe-se já esta guerra. Pelo sangue que Ele derramou por nós, eu o peço aos que não comerçaram a entrar em si; e os que já começaram, que nada seja bastante para fazê-los voltar atrás. Olhai que é pior a recaída do que a queda. Quanto tempo perdido. Confiai na misericórdia de Deus e nada em vós mesmas e vereis como Sua Majestade leva a alma de umas moradas a outras, colocandoa na terra onde essas feras não a podem tocar, nem cansar; pelo contrário, ela as sujeita a todas e zomba delas, usufruindo de muito mais do que poderia desejar, já nesta vida ${ }^{970}$.

Assim o cristão é convocado a determinar-se frente ao seu processo de crescimento, enquanto sujeito humano e espiritual e a tomar consciência de sua existência, apropriando-se do sentido da sua própria vida. Já não mais assujeitando aos seus limites, às suas dificuldades, mas pela via da conscientização do que lhe acontece. Ao refletir e ao conhecer melhor vai tornando-se, no real sentido da palavra "sujeito". Sujeito de si, de seu ambiente, de sua sociedade, sujeito da história. A transformação e a evolução do ser humano como diz Teresa é visivelmente de Deus, da ação do seu Espírito na pessoa, mas a graça conta com a natureza. Para evoluir a pessoa precisa deixar Deus agir. 
Ele é rico em misericórdia para com aqueles a quem dá graça e ânimo para que se decidam a procurar esse bem com todas as forças; porque Deus não se nega a quem persevera, habilitando pouco a pouco o seu ânimo a alcançar a vitória. Digo ânimo, porque são muitas as coisas que o demônio põe diante de quem começa, para impedi-lo de começar, de fato, esse caminho. Porque este último sabe do prejuízo que tem ao perder não somente essa alma, mas muitas. Se o iniciante se esforça com o favor de Deus, para chegar ao auge da perfeição, creio que nunca vai sozinho ao céu, levando sempre muita gente consigo; como a bom capitão, dá-lhe Deus quem vá em sua companhia ${ }^{971}$.

Assim, nessa fase de relacionamento com o Senhor, conforme diz Teresa sobre as segundas moradas, a pessoa encontra-se no princípio da vida de oração $^{972}$. Por isso é, também, uma fase de amizade e de enamoramento. Estar em atitude de oração é ter consciência de se estar em relação com o Senhor.

Pelo que posso entender, a porta para entrar nesse castelo é a oração e reflexão. Não digo oração mental mais do que vocal; para haver oração é necessária a reflexão. Não chamo oração aquilo em que não se percebe com quem se fala e o que se pede, nem quem pede e a quem; por mais que se mexam os lábios, não se trata de oração. E, se algumas vezes o for, mesmo sem esse cuidado, será por motivos que justifiquem ${ }^{973}$.

Desta forma, ao "leitor de hoje lhe interessa, sobretudo estas segundas moradas onde Teresa vai propor uma especial versão da ascética cristã, antes de introduzí-lo à mística da graça" ${ } 974$. E, se aqui o orante, fica atento à presença d'Aquele que antes, desconhecia, logo após tê-lo percebido, sente-se tocado e atraído pelo olhar deste Outro percebendo se alguém o olhou, é porque ele tem valor. E a pessoa reflete: se tenho algum valor, algo tenho a oferecer. Envolvida por este olhar amoroso que lhe é dirigido, necessita recorrer a um duplo movimento: voltar-se para dentro de si (interiorização) para descobrir o que tem a doar, para em seguida descentrar-se (exteriorização) e oferecer a outros aquilo que tem de melhor ${ }^{975}$. Assim, nota-se que

A experiência de Teresa de Jesus se move no âmbito da subjetividade moderna; mas a ultrapassa. Seu conhecimento da verdade do homem se produz de forma paradoxal, como explica a antropologia psicológica: 'Ao curvar-se sobre o centro de si próprio, o homem encontra-se descentrado de si mesmo e centrado sobre o Outro - neste caso Deus [...], ao esvaziar-se de tudo o que lhe enche o psiquismo, o homem entende a voz do Outro no mais íntimo de seu ser; encontra de novo o seu próprio ser, centrado em si mesmo, pelo Outro, ${ }^{976}$.

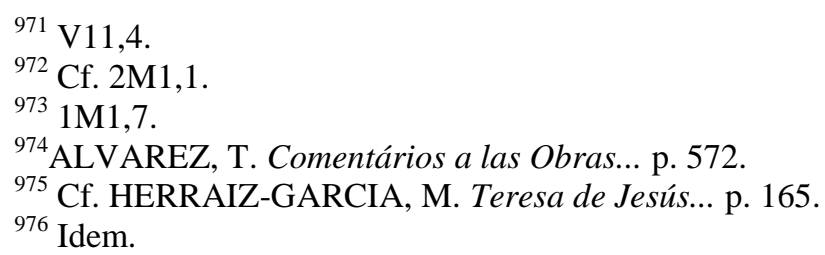


Da mesma forma como se volta ao Outro de Deus, volta-se ao outro do irmão. É o processo de meditação, de reflexão, de recolhimento dos sentidos, do dar-se conta, do sensibilizar-se com a presença de Deus o que também a fará sensibilizar-se e voltar-se em direção aos que a cercam. Ao acolher o olhar do outro, estabelece fina sintonia e prossegue na troca: Ele me olha, eu o olho. E nesta troca de olhares, vai assimilando a revelação ${ }^{977}$ onde ambos vão perceber semelhanças, diferenças, singularidades, afinidades e sentir, um pelo outro, empatia $^{978}$.

Empatia é uma atitude profunda de comunhão e de comunicação com a outra pessoa. Supõe a fé[...] nas potencialidades do outro, afirmação do valor e da importância que o outro tem[...] a empatia faz com que a pessoa seja capaz de se relacionar com as pessoas com alguma gratuidade e generoso desinteresse, vivendo uma autêntica hospitalidade ${ }^{979}$.

E, ao envolver-se progressivamente nessa relação de amizade e ao criar maior vínculo, se desenvolverá num nível de maior proximidade e intimidade. Contudo, pelo fato do outro ainda ser um tanto desconhecido, a entrega ainda é limitada, não total. Mas é atraente e agradável, pois fica com o sabor da descoberta, do encanto pelo novo, do desejo de querer estender prolongadamente este estar a sós e este olhar amoroso de um para com o outro. O que vai configurando a pessoa e delineando nela um sinal distinto de pertença ao outro. Isto, também, intensifica a relação de presença, de ambas as partes.

Nesta fase de encantamento, também o amor pode ser cheio de paixão $e$ cego, porque "a paixão atropela a razão" $" 980$. De modo que, as intensas lutas que Teresa fala das segundas moradas (conflitos) aqui pode se entender também como a falta de integração das suas potencialidades, de seu afeto, a desarmonia interior, de forma que: ou a pessoa ama muito, praticamente ficando o tempo inteiro pensando no outro, superprotegendo este amor, ou então, decide-se a não amar mais e o abandona. Situa-se entre extremidades e o equilíbrio, às vezes torna-se difícil. De modo que, semelhante ao sentido existencial teresiano, pode-se falar, também, no suicídio do amor, porque:

\footnotetext{
${ }^{977}$ Cf. RUBIO, A. G. Nova Evangelização e maturidade afetiva... p. 112.

${ }^{978}$ Ibidem. p. 114.

979 Idem.

980 TURKENICZ, A. A aventura do casal: Uma abordagem teórico-clínica. Porto Alegre: Artes Médicas, 1995. p. 18.
} 
Nem sequer o amor que os amantes tenham pela própria vida é tão poderoso quanto os ímpetos desencadeados pela paixão. Assim, o suicídio é a maneira de dizer que a vida não faz sentido se não puder abrigar a paixão ${ }^{981}$.

Assim o suicídio, ou a opção de não amar e de não crescer no amor, são atitudes possíveis à escolha humana. Porque ao deparar-se com as interpelações intensas de dar sentido, significado à vida, responde à própria vida que se não puder amar em sua plenitude, a vida não faz sentido! Há que se "chorar pela semente que morreu sem florescer" ${ }^{\prime 982}$.

A intuição e o realismo religioso sugerem ao orante não permanecer nos gostos e nas consolações da paixão inicial, porque como diz Teresa, não é aí que reside o verdadeiro amor. Nota-se que, aqui, embora seja uma fase mais elevada que a anterior, ainda esse amor frágil apresenta-se pouco iluminado pelo núcleo da luz e pelo fulgor de sua expressão verdadeira. Precisa avançar em seu próprio processo de crescimento, para chegar aonde o verdadeiro sabor desta relação se fará sentir com maior evidência ${ }^{983}$, contudo já se ilumina um pouco mais agora e, adiante, o bem será mais fecundo e superará este, que apenas se delineia.

Notareis que essas primeiras moradas quase não recebem nenhuma réstia da luz que sai do palácio onde está o rei. Embora não estejam escuras e negras como quando a alma está em pecado, estão de alguma maneira, obscurecidas e não se consegue ver quem está nelas. Isso não por culpa do aposento [...], mas porque entraram com a alma tantas cobras, víboras e animais peçonhentos que não a deixam ver a luz. É como se alguém entrasse num lugar com muita claridade e, tendo um cisco nos olhos, quase não os pudesse abrir. $\mathrm{O}$ aposento está claro, mas a alma não o percebe por causa dessas feras e alimárias, que a obrigam a fechar os olhos para não ver senão a elas ${ }^{984}$.

Deste modo, não é por culpa do aposento, mas a pessoa depara-se com suas próprias dificuldades e, esbarrando nelas, ainda não consegue estender mais adiante, ou mais profundamente, seu olhar. Contudo, já dá um passo além, voltando-se e respondendo ao chamado, ao olhar e à presença de Deus, dentro de si. Aí nasce, também, a relação de cuidado, que é a característica singular, a própria demonstração da amizade e do amor. E o cuidado, conforme Heidegger, é "o fenômeno básico constitutivo da existência humana"985. Por isso, pode-se dizer

${ }^{981}$ Ibidem. p. 18.

${ }^{982}$ Alusão à música "O homem”, de Roberto Carlos.

${ }^{983}$ Cf. $2 \mathrm{M} 1,8$.

$9841 \mathrm{M} 2,14$.

${ }^{985}$ RUBIO, A. G. Nova Evangelização e maturidade afetiva... p. 113. 
que o orante, nesta etapa, desenvolve para com Deus o trato, do qual Teresa tanto fala ${ }^{986}$, ou seja, o trato é uma relação de cuidado.

Desta forma, reconhecendo-O em seus atributos, dedica-lhe seu tempo, expressa seu carinho, sua ternura, desenvolvendo cuidados, contemplando-o e dirigindo-lhe não só o olhar, mas também a palavra. Acolhe, seu dom e se exprime, livremente, nesta comunicação. E, Deus mesmo, vendo tudo, não repara a situação em que se encontra este orante, porque está completamente enamorado de sua criatura e desdobra-se para conquistar sua pessoa, pois Ele, mais do que ninguém reconhece seu autêntico valor. Estando aí "a fitar o olhar em Cristo intensa e amorosamente" ${ }^{987}$, na simplicidade de seu ser, oferece a Ele aquilo que é e o que tem. Da parte de Deus, como diz, São João da Cruz, coadunando-se à mensagem teresiana: "para enamorar-se de uma alma, Deus não olha a sua grandeza, mas a grandeza de sua humildade" ${ }^{988}$.

Assim, o exercício de se colocar nessa presença do outro (Deus) e em Deus, diante dos outros (irmãos), é um exercício de diálogo e de encontro. E à pessoa vem o convite: "Levanta-te, minha amada, formosa minha, vem a mim"989! Por isso, as emoções e inspirações deste período são fortes e contrastantes, pois a pessoa, ao sentir-se interpelada, sente-se mobilizada pelo suave toque da divina graça, o silvo do pastor, que desde as primeiras fases, fica a atraí-la. Ali, junto d'Ele, com desejo de transcender-se, de voltar-se aos demais, por momentos tem relâmpagos de um maior grau de consciência: "encontrei o Amado de minha alma. Agarrei-O e não vou soltá-lo"990. E, envolvida por um sentimento de profunda gratidão, vira-se novamente para Ele, sussurra-lhe ao ouvido: "Como és belo meu Amado" "991, "roubaste o meu coração"992! Agora, "grava-me como um selo em teu coração, como um selo em teu braço, porque o amor é forte, é como a morte" 993 ! Desta forma, a pessoa vai despertando, gradativamente, ao verdadeiro amor. Por Teresa referir que esta morada é cheia de alternâncias e lutas, pois

${ }^{986} \mathrm{Cf} . \mathrm{V} 8,5$.

${ }^{987} 2 \mathrm{M} 1,11$.

988 SÃO JOÃO DA CRUZ. Ditos de luz e de amor. n. 101. In: SÃO JOÃO DA CRUZ. Obras Completas. 6. ed. Petrópolis: Vozes, 2000. p. 101.

${ }^{989} \mathrm{Ct} 2,10$.

${ }^{990} \mathrm{Ct} 3,4$.

${ }^{991} \mathrm{Ct} 1,16$.

${ }^{992} \mathrm{Ct} 8,6$.

${ }^{993} \mathrm{Idem}$ 
muito embora o desejo de avançar, seja fácil também retroceder, às moradas mais baixas, dá-se à essa fase o nome de: fase da inconsistência.

\subsection{3}

\section{Fase da transcendência}

Vida não significa algo vago, mas sim algo muito real e concreto, assim como os desafios da vida são também muito reais e concretos. Eles constituem o destino dos homens, que é diferente e único para cada indivíduo. Nenhuma pessoa e nenhum destino podem ser comparados com qualquer outra pessoa e destino. Nenhuma situação se repete e cada situação exige uma resposta diferente. Por vezes, a situação em que um homem se encontra, pode exigir-lhe que molde seu próprio destino por meio da ação. Outras vezes, é mais vantajoso para ele aproveitar uma oportunidade para a contemplação e, dessa forma, avaliar os seus trunfos ${ }^{994}$.

Sabe-se que "não é possível, humanamente, manter o estado de apaixonado"995. Por isso, deixando a fase da inconsistência o orante parte para uma relação um pouco mais estável. Já é um passo mais no castelo. É a fase de transcendência, no sentido de Frankl. Nesta fase a pessoa está consciente da relação com o outro e encontra-se numa disposição de maior abertura a ele. "Teresa fala de uma jornada de ascese, vigilância e de esforço. Fala do amor e dos riscos de espelhismo e narcisismo" 996 , mas para a pessoa dessa fase já é maior o grau de entrega e consciência. Assim, aqui, conforme Teresa, tem se a fase do maior conhecimento de si e de conhecimento do outro. A palavra-chave que, aqui, usa-se para expressar esse aprofundamento é a transcendência. Conforme os ensinamentos de Teresa, considera-se que a pessoa, nesta fase, tendo já resolvido seus conflitos básicos, encontra-se num nível humano e espiritual, já mais estável. Encontra-se de modo mais sereno na relação com Deus, o que significa que no relacionamento com o outro humano, também estará.

Àqueles que, pela misericórdia de Deus, venceram esses combates, adentrando pela perseverança nas terceiras moradas, que lhes diremos, senão: Bemaventurado o homem que teme ao Senhor? Não foi pequena graça [...]. Sem dúvida é com razão que chamamos de bem-aventurado quem teme o Senhor, pois, se não retrocede, percorre- a nosso ver- o caminho seguro de sua salvação ${ }^{997}$.

\footnotetext{
${ }^{994}$ FRANKL, V. Psicoterapia e sentido da vida. São Paulo: Quadrante; 1973. p. 77.

995 JOHNSON, R. A. A chave do entendimento da Psicologia Feminina: Uma interpretação baseada no mito de Eros e Psique, usando conceitos psicológicos jungianos. São Paulo: Mercuryo, 1987. p. 50.

${ }_{996}^{9}$ ALVAREZ, T. Comentários a las Obras... p. 581.

997 3M1,1.
} 
Nesta serenidade, a pessoa sabe reservar bons momentos de recolhimento e de reflexão para melhor conhecer a Deus, a si mesma, o seu sentido existencial, o que pode fazer em prol da sociedade, como ajudar mais concretamente a seus irmãos. A partir disso, dispõe-se a organizar sua vida em função da proposta cristã e a relacionar-se, ainda mais significativamente, com o transcendente percebendo de quais realidades está cercada. São pessoas virtuosas, discretas, interessadas no bem do próximo sabedoras de que estão aqui nesta peregrinação terrena com $o s$ olhos no céu, mas com os pés no chão, pois por um chamado peculiar de Deus tem consciência de que tem no mundo uma missão a cumprir. Assim:

as pessoas dessas moradas tem grande desejo de não ofender Sua Majestade [...]. Tem seus momentos de recolhimento e empregam bem o tempo, exercitando-se em obras de caridade para com o próximo ${ }^{998}$.

Para responderem a Deus e colaborarem com Seu Projeto, envolvem-se com tarefas que cumpram a finalidade de sua existência, não medindo esforços, nem generosidade, de melhor servir a Deus e a ao próximo. Pela graça que o Senhor oferece às pessoas que se encontram neste nível, já se elevaram humana e espiritualmente sendo amigas da disciplina e da entrega existencial ${ }^{999}$. Assim, a pessoa aqui encontra-se habilitada a não deixar a vida correr no cotidiano a seu bel-prazer sem obter, de alguma forma, por mínimo que seja, algum proveito para seu crescimento e do outro.

Portanto, esta fase de transcender-se é também a fase da amizade espiritual, pois quando se passou a fase da ebulição da paixão, o amor começa a consolidarse e consolidando-se, ainda mais o relacionamento, transparece como verdadeiro amor. Sendo a entrega ao amor de um grau mais elevado que a fase antecedente, possibilita as pessoas a prepararem-se ao discernimento desse amor e da sua vocação, conduzindo-as a um amadurecimento ainda maior. Nesta fase é necessário muita fé e dedicação. Lembrando de que fé e amor só têm sentido, quando dirigidos a uma Pessoa ${ }^{1000}$.

Teresa situa essas moradas trazendo a passagem do jovem rico. Assim, a pessoa dessa fase zela pelo que conheceu de Deus e, como o jovem rico, "quer ser perfeita para Ele". Por isso, vende todos os seus bens para, tanto quanto possível,

\footnotetext{
$9983 \mathrm{M} 1,5$.

999 Idem.

1000 "É justo e bom entregar-se totalmente a Deus e crer absolutamente o que ele diz". CEC 150.
} 
embelezar-se para seu Amado e ser-lhe presença ${ }^{1001}$. Abraçada n'Ele, indo para um novo sítio ${ }^{1002}$, quer passar pela porta estreita ${ }^{1003}$, pois como já está muito junto de Quem tanto ama, pela porta larga, por onde poderia distanciar-se d'Ele, ou perdê-Lo, não quer passar ${ }^{1004}$. E ela percebe que a convivência com Cristo é um tempo de graça, de gratuidade da parte de Deus, tempo forte de conhecimento mútuo. Por isso, procura aproveitar bem o momento que reservou e programou para estar com Ele. E o Senhor não só a escuta, mas também lhe fala interiormente, pois quer que a pessoa conheça ainda mais profundamente $o$ dom de Deus ${ }^{1005}$ e a bênção que Ele próprio é para sua vida, pois deste modo, poderá entender muito mais do que seu momento presente e, também a este, transcenderá. Desta forma, fortifica-se no desejo de crescimento humano e espiritual.

Só que, por mais que a pessoa aspire à "perfeição" (sentido de grau mais elevado do amor ${ }^{1006}$ ) e empreenda todos seus esforços para responder ao amor do Senhor usando "as jóias" que Ele lhe deu, sua dedicação ao amor ainda não é tão forte, a ponto de responder bem e em tudo confirmar a firmeza e coerência dessa relação. Quando as provas lhe advêm, geralmente, angustia-se, fica perturbada, vê que não está suficientemente desapegada de tudo e, ainda, não se sente tão segura desse amor, para entregar-se, de todo e dedicar-se somente a Ele ${ }^{1007}$.

Conheci algumas almas, e creio que posso dizer bastante, que chegaram a este estado. Elas tem vivido muitos anos, ao que parece, nessa retidão e harmonia de alma e corpo. E, depois disso, quando deviam estar com o mundo sob os pés ou pelo menos plenamente desenganadas dele - são provadas por Sua Majestade em coisas não muito grandes; ficam então de tal modo inquietas e com o coração tão angustiado que me deixam perplexa e até muito temerosa ${ }^{1008}$.

Deste modo, em suas provações responde com um comportamento de quem se sente mal interpretada, fica com o olhar altivo e, por vezes, cruza os braços, para não dar um pouco mais de si, resistindo avançar. E o Senhor, pedagogicamente, aguarda por um tempo mais oportuno, espera por ela para o

\footnotetext{
${ }^{1001}$ Cf. Mt 19,21.

1002 Nova etapa.

1003 A porta estreita que dá entrada para a vida eterna é a fiel observância da lei divina. Mt 19,17 .

${ }^{1004}$ Cf. Mt 19,17.

${ }^{1005}$ Cf. Jo 4,10.

${ }^{1006}$ A própria Teresa explica que perfeição é amor: "Entendamos filhas minhas, que a verdadeira perfeição é o amor a Deus e ao próximo. Quanto mais fielmente guardarmos esse dois mandamentos, tanto mais perfeitas seremos. A nossa Regra e as nossas Constituições, em seu conjunto, não servem senão de meios para seguir isso com mais perfeição". 1M 17.

${ }^{1007}$ Cf. 3M2,5.

${ }^{1008} 3 \mathrm{M} 2,1$.
} 
momento em que esteja mais aberta e disposta a dialogar. Desta forma, o relacionamento se estreita e ambos vão se conhecendo mais e mais. As pequenas discrepâncias existentes nesta relação ora se dissolvem, ora se integram, num maior ajustamento das duas personalidades que, nesta etapa, precisam harmonizar seu jeito de ser e de conviver. Entretanto, o mais habitual é que a pessoa ao estar a sós com o Senhor, sinta-se amada e ouvida e, por sua vez, gosta de perder tempo com Ele.

Após cada momento, de mais forte de comunhão, a pessoa com renovado júbilo, levanta-se e ordena sua casa e sua vida em função do seu Amado, de seus gostos e referencias, procurando de todas as maneiras agradá-lo e tudo dispondo do melhor modo possível para deixá-lo ainda mais feliz ${ }^{1009}$. Contudo,

É possível que nem saibamos o que é amar; isso não me espantaria muito, porque o amor não está no maior gosto, mas na maior determinação de desejar contentar a Deus, em procurar, na medida do possível, não ofendê-Lo e em pedir-lhe o aumento contínuo da honra e da glória de Seu filho[...]. São esses os sinais do amor, e não penseis que a oração consista em fixar o pensamento num só ponto, nem que tudo estará perdido se vos distrairdes um pouco ${ }^{1010}$.

Por ser esta fase onde o amor é provado e uma fase de maior entrega à mística e às grandes trocas, onde a pessoa lança-se vivamente em direção a Deus e aos outros, chama-se a esta de: fase de transcendência.

\subsection{4}

\section{Fase da benevolência}

Não existe verdadeira amizade e amor sem comprometer-se. Portanto esta é a fase de uma entrega maior e de um comprometimento mais eficaz em relação à Deus, ao ambiente em que vive e aos irmãos. Compromisso é a palavra-chave. Porque o amor verdadeiro sempre compromete as pessoas. Ao chegar nesta fase, desejosa de firmar um maior comprometimento com o Amado, a pessoa visivelmente já se determinou e se definiu deveras por Deus. Sua entrega é mais amadurecida e sua opção de vida mostra-se com essa aliança de sua fidelidade ao amor. A mão da aliança definitiva é a direita. O lado direito sempre representa o lado da nobreza, da decisão, da objetividade, do seguimento continuado. Ou seja,

1009 Cf. 1 Cor $7,32$.
1010 4M1,7. 
a aliança, na mão direita, que um coloca no outro, também é a expressão simbólica do estar decidido à fidelidade no amor e na entrega que desejam viver doravante, um ao outro, assumindo um comprometimento, ainda mais sério, e profundo. Por isso Teresa adverte ao que peregrina nas moradas do Castelo, nesta fase não se abandona a oração. Embora ainda se tenha muito a avançar até a maturidade plena do amor, é preciso perceber que este comprometimento pelo outro é o que mais importa e o que define a relação. Assim, não vale a pena deterse no que não está bem, enquanto se tem ainda um caminho pela frente, contudo, aqui o "coração já se alarga" mais amplamente ${ }^{1011}$. Neste sentido, para avançar nesta relação de amizade e de amor, pois ainda tem fases mais elevadas para percorrer, é fundamental apoiar-se, com firmeza, naquilo que já alcançou e buscar, com todo o empenho, dentro de si, todas as forças necessárias para chegar aonde se propõe. É preciso como fala Teresa: mirar o fim ao qual quer chegar, que é a união mais plena com o Esposo ${ }^{1012}$. Desta forma, a pessoa dessa fase, procura perceber o caminho, estabelecer metas para atingi-lo e tem a confiança de que

se ela não faltar a Deus, jamais Ele - ao que me parece - lhe faltará ou deixará de comunicar-lhe tão claramente a Sua presença. E ela tem grande confiança no fato de que Deus não a abandonará, pois se Este lhe concedeu tamanha graça, não permitirá que a perca. E é justo pensar assim, ainda que não deixe de agir com mais cuidado do que nunca, a fim de não desagradar o Senhor em nada ${ }^{1013}$.

Deus não faltará com a pessoa a fim de que ela atinja o alvo da união mais profunda, um grau mais elevado do amor ${ }^{1014}$. Neste sentido, as discrepâncias que ainda existem, nesta fase, aos poucos serão integradas, porque é o Senhor quem a eleva e promove a união. Seu comprometimento, mostra-se, sobretudo, pela generosidade da entrega de seu coração, porque "a principal coisa a fazer neste caso: é amar a Deus sem interesse" ${ }^{, 1015}$.

Por isso, nesta fase, o tempo é oportuno para aprofundar sua amizade a ponto de unir vitalmente sua vida à Deus, seus ideais, seus objetivos e projetos futuros, em vista a tornar-se verdadeiramente "uma só alma e um só coração"1016. As dificuldades externas em relação à pessoa já não mais a abalam como nas

\footnotetext{
${ }^{1011} 4 \mathrm{M} 2,5$.

${ }^{1012}$ Cf. 7M2,5.

1013 7M1,8.

${ }^{1014}$ Idem.

1015 4M2,9.

1016 At 4,32.
} 
primeiras etapas da relação. A transparência e a limpidez são características evidentes. Sua vida de justiça e retidão, a coerência no amor, neste relacionamento com Deus, e todas as virtudes estão mais fortalecidas, porque nessas pessoas há uma mescla de natural e sobrenatural ${ }^{1017}$. Suas potencialidades agora centram, com mais atenção ao outro e dirigem suas forças para uma maior concretização do seu amor. Os gostos de Deus tornam-se mais intensamente os gostos da pessoa ${ }^{1018}$ e a completa união já é próxima. Bem mais sólido e fortalecido o amor ágape, o amor de virtudes, como diz Teresa.

Assim, por meio da contemplação de Deus e da contemplação às realidades da vida, a pessoa vai integrando e coadunando seu jeito humano ao jeito de ser divino, à proposta de Deus para sua vida e entregando-se mais inteiramente ao Amor. Compreende que "nesta obra de espírito, quem menos pensa e quer fazer, é quem mais faz" ${ }^{\prime 1019}$. Por isso, ao perceber a suavidade da Presença de Deus e ao lançar-se a serví-lo, serve-O nos irmãos. Percebe que isso acontece porque seu coração se dilata de tanto amor. Assim, aquele encanto do primeiro amor se reedita e se renova, emergindo, agora, ainda mais com força. Contudo, agora é bem maior, transbordante, porque avançou no estágio de relacionamento com o Senhor, cresceu humana e espiritualmente e aumentou sua capacidade de tudo saborear ${ }^{1020}$. Presentemente, já tão modificada a pessoa avança nesta relação de amizade e de amor e tem um novo jeito de olhar para o panorama do mundo. Vendo-o, agora, ainda mais com os olhos e a ternura de Deus, vê que pode ser modificado, melhorado, porque como sujeito humano e espiritual o amor deve ser a força de alavanca. Desta forma, insere-se mais profundamente na sua trajetória terrena, envolvendo-se como "fermento na massa" nas angústias do povo de Deus que sofre em meio às jornadas desta vida. É, como se desse um mergulho e nesse mergulho, no movimento das águas da sua ação, pudesse envolver também a outras pessoas neste mar das graças de Deus, para compreenderem, acolherem e amarem o Seu grande amor e serem distintivos do amor de Cristo aos irmãos. A prova da autenticidade de seu amor se verá, depois, "nas suas obras" 1021 , na forma

\footnotetext{
1017 4M3,14.

1018 4M 1,4.

1019 4M3,5.

${ }^{1020}$ Cf. 4M2,4.

1021 4M3,9.
} 
como se relaciona com os irmãos, como prepara e organiza sua vida, centrando-a nessa unicidade de seu amor e na liberdade do serviço de Deus.

Por ser esta fase, a fase em que se mescla o natural com o sobrenatural, pode se dar a ela o nome de: fase da benevolência, porque a pessoa vai se ajustando mais ampla e complacentemente ao movimento divino dentro de si.

\subsection{5}

\section{Fase da transparência}

Ora o tipo de amor mais perfeito e completo é o 'louco', ou o 'radical'. Se esta doação total, de tudo o que se vive, é feita a Deus, diretamente, resulta dela um estado de consagração. Aqui Teresa fala de um recolhimento e amor e de um amor infuso. Assim a pessoa conduzida pela ação do Espírito, ama virtuosamente na caridade, se ama no coração de Cristo, como Ele amou e ama-O, nos outros. Assim, como no matrimônio no qual a pessoa não pode se dar de uma maneira total, absoluta e profunda a dois cônjuges, ao mesmo tempo, aqui, o amor maduro comporta 'unicidade'. Deste modo, consagrando-se, livremente, a um amor radical, diretamente unido ao seu Criador, deixa transparecê-lo em sua vida e obras. Desta maneira, sua consagração ao Senhor é, ao mesmo tempo, consagração ao amor. Aqui a Teresa lhe vem à mente as belas imagens utilizadas por Osuna no Terceiro Abecedário: "a de recolher-se como a tartaruga que se encolhe em seu casco e encerrar-se" ${ }^{, 1022}$. Por isso é que nessa fase a pessoa rompe, determinantemente, com toda e qualquer incoerência, por menor que seja, na relação e no serviço a Deus. Teresa diz que o que ocorre nesta fase é que "Deus se fixa a si mesmo no interior" da pessoa ${ }^{1023}$ e concede-lhe a graça e a misericórdia de deixar que ela o conheça melhor, aproximando-a, ainda mais, junto de Si. E ao seu modo de ver "Deus nos dá as potências para que com elas trabalhemos". Todas as potências estão intrinsecamente envolvidas nesta realidade da união. A ação de Deus fica impressa na sua memória e na vida da pessoa para sempre. Segundo Teresa "a alma sabe que esteve em Deus e Deus nela"1024.

${ }^{1022}$ ALVAREZ, T. Comentários a las Obras... p. 611.

${ }^{1023} 5 \mathrm{M} 4,4$.

${ }^{1024} 6 \mathrm{M} 3,5$. 
Este momento-auge é como uma transfiguração, onde quem se desenvolveu numa intensa relação de amizade com Deus, fica assemelhado a Ele, transfigurado, cheio de luz, semelhante a Moisés ao descer do monte ${ }^{1025}$. A luminosidade testemunha que a pessoa esteve com Deus. Assim o amor no qual agora se entrelaça, nada poderá romper ${ }^{1026}$.

Aqui, a pessoa firma-se em sua contemplação mística e seu relacionamento com Deus é, de todo, amplamente estreitado. Tendo, particularmente, aproveitado dos meios ordinários que o Senhor deixou em sua Igreja para chegar aonde chega, tem o coração enlevado pela ação do Espírito Santo que lhe infunde a luz, o amor e move-lhe a vontade. Em suas mãos, deixa-se conduzir e corresponde às graças recebidas. Ao longo de sua trajetória interior foi preparando, essa sua maior transformação ${ }^{1027}$. Agora, a mudança na sua vida é total. Nem se reconhece mais como serva, mas como amiga, como esposa. O grau de seu amor e entrega a Deus e aos irmãos é grande. E o amor que consagra a Deus promove a unidade indissolúvel. Retamente, forma sua consciência e suplica a Ele a graça da perseverança nesta nova etapa de vida, para ser com Ele, de fato "uma só alma e um só coração"1028. A prática de sua vida deixa ao mundo o testemunho vivo da presença de Deus entre todos. Assim:

Ao começar com as quartas moradas, a oração contemplativa mística, é normal que a 'iniciativa' de Deus e a infusão de luz e de amor no orante deixem as melhores recomendações que[...] transbordam sobre a vida do contemplativo, condicionado em sua conduta fraterna, configurando suas coordenadas psicológicas e sobretudo marcando mais e mais a dimensão teologal e cristológica, no primado de Deus e na vida da ação ${ }^{1029}$.

Por Teresa acentuar que, aqui, a alma está mais senhora de si, que há dilatamento de amor em seu coração, onde se apagam os medos, a pessoa entregase ao Senhor e em nada se dispensa de servir, de trabalhar e de crer e, por ser esta a fase em que Deus, notadamente começa a transparecer na vida da pessoa, podese chamá-la de: fase da transparência.

\footnotetext{
1025 Cf. Ex 34, 29-35.

${ }^{1026}$ Cf. 5M1,5.

${ }^{1027}$ Cf. 5M2,3

1028 At 4,32.

${ }^{1029}$ ALVAREZ, T. Comentários a las Obras... p. 615.
} 


\subsection{6}

\section{Fase da resplandecência}

Sim, aproximai-vos pensando e compreendendo com quem ides falar, ou com quem estais falando. Em mil vidas das nossas não conseguiremos entender por inteiro como merece ser tratado esse Senhor, diante do qual os anjos tremem. Ele tudo governa, tudo pode; seu querer é operar. Há pois, razão, filhas, para que procuremos deleitar-nos nessas grandezas que tem o nosso Esposo e para que compreendamos com quem estamos casadas e que vida havemos de ter ${ }^{1030}$.

Aqui há ainda mais provações no amor. E a esposa, devido ao comprometimento que tem com o Esposo, precisa passar por muitas delas: murmurações de pessoas próximas e desconhecidas, difamação, calúnias. Contudo, a expressão do divino Esposo, desde as últimas moradas imprime-se na memória, sustentando-a em toda adversidade. E a força da sua Presença é tal, que as palavras infundem na esposa a segurança ao seu agir, fazendo-a, mesmo em meio às piores dificuldades realizar tudo aquilo que elas dizem ${ }^{1031}$. Para corresponder ao amor fiel do Senhor deseja ser-lhe, também, muito fiel em cuidar de tudo aquilo que lhe diz respeito, sem descuidar-se das pequeninas coisas.

Aqui nesta etapa, a jovem esposa muito ciente de que "os sofrimentos da vida presente não tem comparação com a glória que há de revelar-se em nós"1032 sabe que tudo o que se lhe apresenta no dia-a-dia são apenas ocasiões para oferecer seu amor a Cristo, porque desde cada oportunidade "tudo concorrerá para o bem daqueles que amam a Deus" ${ }^{\text {1033 }}$. Sabe que os sofrimentos pelos quais, por ora, passa podem ser vislumbrados, e até mesmo desejados, como recursos que melhor irão prepará-la à sua condição atual: de esposa e de quem gestará em si mesma os frutos dessa profunda união.

Porém esta união do homem com Deus passa através da morte, uma maneira de morte radical à anteriores forma de vida humana, tão arraigada ao terrestre, tão limitada pelo lastro do mal e do pecado. Passa pela morte para chegar a união $^{1034}$.

Diz São Paulo que "todos os sofrimentos do mundo não são dignos da glória que esperamos" ${ }^{\prime 1035}$. Adianta-se, pois à pessoa desta fase, já nesta peregrinação

\footnotetext{
${ }^{1030} \mathrm{C} 22,7$.

${ }^{1031}$ Cf. $6 \mathrm{M} 4,8$.

${ }^{1032} \mathrm{Rm} 8,18$

${ }^{1033} \mathrm{Rm} 8,28$.

${ }^{1034}$ ALVAREZ, T. Comentários a las Obras... p. 631.

${ }^{1035} \mathrm{Rm} 8,18$.
} 
terrestre, o Paraíso que viverá eternamente com Deus. e, disso, dá seu testemunho de vida. Ao acordar, numa nova manhã, para novamente tudo entregar ao Senhor, a esposa expressa com seu interior cheio de Deus: "Eu dormia, mas meu coração velava" ${ }^{1036}$. Ou seja, dia e noite, a pessoa dessa fase, zela pela causa de Deus e medita na lei do Senhor ${ }^{1037}$. E a cada novo momento do dia, com os novos afazeres que lhe são apresentados, tem consciência de que não é apenas uma nova tarefa a cumprir, mas é a voz do Senhor que toca à porta do seu coração para pedir a sua amada um novo ato de amor e ela o escuta, sensivelmente: "Eis a voz do meu Amado, Ele bate ${ }^{1038}$ !” E, assim, não quer outra coisa no dia, e em toda a sua vida, a não ser responder, com amor, àquilo que, com tanto amor, Ele vai lhe pedindo ${ }^{1039}$. A esposa suspira: "eu sou do meu Amado e meu Amado é para mim"1040. E, assim, viver para Deus, e para os irmãos, em seu amor, é o que realmente lhe importa, o essencial. Tudo o mais: como, em quê e onde servi-lo, lhe é secundário. Mas de estar e permanecer unida a Ele, disto não abre mão.

Por isso, aqui se fala dessa união das vontades, da união da cultura divina, unida à humana. Embora já integradas, ambas as culturas dos contraentes são distintas, a ponto de se saber o que faz parte do divino e o que ser refere ao humano, pois, enquanto Ele, por exemplo, vislumbra a missão, o Projeto a realizar para a edificação de Sua Casa, a esposa acolhe com doçura aquilo que o Amado expressa e, toma o cuidado desde as pequenas coisas de preparar, sobretudo, a interioridade de sua casa, para a doação de si ao divino Esposo e à geração dos filhos, que virão, como frutos desse amor espiritual ${ }^{1041}$. Por ser esta fase a mais próxima da luz, do "Sol" da última fase, do seu núcleo mais vivicante, pode se chamar a esta de: fase de resplandescência.

\footnotetext{
${ }^{1036}$ Cf. Ct 5,2.

${ }^{1037}$ Cf. Sl 1,1.

${ }^{1038} \mathrm{Ct} 5,2$.

1039 "Orar nos acontecimentos de cada dia e de cada instante é um dos segredos do Reino revelado aos 'pequeninos', aos servos de Cristo, aos pobres das bem-aventuranças. É justo e bom orar para que a vinda do Reino de justiça e de paz influa na marcha da história, mas é também importante modelar pela oração a massa das humildes situações do cotidiano". CEC, 2660.

${ }^{1040} \mathrm{Ct} 6,3$.

1041 "Com freqüência a Igreja é também chamada de construção de Deus[...] Essa construção recebe vários nomes: casa de Deus[...] morada de Deus [...] pois nela quais pedras vivas somos edificados nesta terra". 1Pd 2,5; CEC, 757.
} 


\subsection{7}

\section{Fase da florescência}

Uma das tarefas mais delicadas e complexas dos pais é crescer junto com o filho, acompanhando seu desenvolvimento, o que evidentemente implica na capacidade de continuamente reformular modos de ser e de atuar para melhor adequar-se às diferentes necessidades e situações que se sucedem ao longo da vida $^{1042}$.

Nesta etapa, o matrimônio espiritual encontra-se num nível de consciência e de doação elevado e é legítima e autenticamente consumado, consolidado ratificado nas obras e no testemunho de vida que a pessoa dá de si mesma. Com isso mostra o quanto sua conduta e sua vida pertencem inteiramente a Deus e que a obra é, verdadeiramente, do Senhor. Aqui, o matrimônio espiritual é experienciado, através da vivência batismal e da amizade primordial do relacionamento com Deus. É o sinal que o arco-íris recorda: a Aliança que Deus fez com a pessoa humana, acenando ao poder do Senhor que, pela vida da graça, Ele concede, generosamente, a todos os seus filhos para fazê-los uma só coisa com Ele, uma raça eleita, um sacerdócio régio, uma nação santa ${ }^{1043}$.

Não está claro que uma alma a quem Deus conceder tão grande graça de uni-la consigo em tanta amizade ficará bem rica de Seus bens? Porque, naturalmente, essas coisas não podem ser nossas. Pedir e desejar que nos faça esse favor está ao nosso alcance e, mesmo assim, com a Sua ajuda. Quanto ao mais, que há de poder um verme, tão acovardado e miserável pelo pecado, que imagina todas as virtudes com a limitação característica de nossa natureza inferior ${ }^{1044}$ ?

Neste estágio de maior plenitude de si, a pessoa sabe que, se entra em seu castelo interior não é para gozar, mas para melhor servir e para dar a Deus o seu devido louvor. E é extremamente importante lançar-se ao serviço dos irmãos, com total dedicação. Aqui há de se considerar como filho: o próprio mundo. Particularmente, no que diz respeito à relação que o orante deve ter com os menos favorecidos, encontrados individualmente, ou em grupos, ou em instituições inseridas na sociedade. Preservar os filhos de passar as dificuldades que os pais mesmo passaram e cuidá-los, mas sem superprotegê-los. Aqui os pais ensinam aos filhos a valorizar o patrimônio que se tem, a tradição, a cultura e os valores da família, o amor que lhes é peculiar.

${ }^{1042}$ MALDONADO, M. T. Vida em Família: Conversa entre pais e filhos. 4 ed. São Paulo: Saraiva, 1996. p. 31.

${ }_{1043}$ Cf. 1 Pd 2,9.

${ }^{1044}$ CAD3, 9. 
É necessário tomar o filho mundo em seus braços, com a mão afagar-lhe o seu rosto e contar-lhe as histórias do passado para que ele valorize suas raízes e atribua significado e continuação ao momento presente ${ }^{1045}$. De modo que os pais, em tudo, procuram educar os filhos para a vida em sociedade, mas, sobretudo, ao chegar à adolescência, ensinam a eles que a generosidade e a fé têm origem, terra e direção e que não podem ser desperdiçadas em banalidades, mas orientadas a um bem maior ${ }^{1046}$. E, sobretudo, é necessário ser para os filhos um testemunho vivo de fé e dignidade, porque, como diz a sabedoria popular: as palavras comovem, mas são os exemplos que arrastam!

O filho mundo precisa ser educado, amado, e para isso, os pais precisam reservar momentos de qualidade e gratuidade para estar com ele e demonstrar-lhe amor, não somente a instar-lhe cobranças e exigências sem fim. É preciso lembrar: ele ainda não tem a maioridade, ou seja, não tem ainda a capacidade e autonomia necessária para lidar com seus próprios inconvenientes. E quando o responsável ${ }^{1047}$ percebe que o filho apresenta algum problema, seja ele de qual natureza for, é preciso, sobretudo, não abandoná-lo nesta hora, mas comprometerse de fato, olhando para a realidade que ali aparece, dizendo-se a si mesmo: É meu filho! E se ele tem algum problema, esse problema é meu também, eu o abraço. E, por meu filho, tudo farei para que ele saia desta situação. Então os pais, a jovem esposa, junto ao Esposo divino, sentam-se junto ao filho mundo para esclarecer sua situação e procurar ajudá-lo. E depois ainda, a sós, sentam novamente, pensando e refletindo sobre a questão, pois querem empreender todos os esforços para melhor ajudar o seu pequeno mundo naquilo que não está bem. E se o problema for maior do que os responsáveis poderiam imaginar e se, ainda, escapa de suas mãos, da capacidade que têm para resolvê-lo, é preciso encaminhar o filho

\footnotetext{
${ }^{1045} \mathrm{Na}$ expressão é necessário tomar o filho mundo em seus braços, compreenda-se: assumir-se como alguém sujeito da história e responsável pela mesma. Com a mão afagar-lhe o seu rosto: significa, naquilo que puder, aliviar suas preocupações e seus sofrimentos e por histórias do passado, compreenda-se: história da vida de um povo, da família de um modo geral, mas principalmente a história da fé cristã, suas raízes, sua cultura, para viver o seguimento de Cristo na sociedade hodierna.

1046 "A fé [...] para ser viva e justificante, ou santificante, deve estar sempre acompanhada pelas virtudes da esperança e da agápe, ou da caridade. Em seu hino à agápe $(1$ Cor 13,2) garante São Paulo aos coríntios: 'Se eu tivesse toda a fé, a ponto de remover montanhas, mas não tivesse agápe, eu nada seria'!’ KLOPPENBURG, B.. Virtudes: frutos que o Pai espera. Petrópolis: Vozes, 2001. p. 66.

${ }^{1047}$ Os responsáveis pelos filhos, geralmente são os pais. Aqui, na analogia usada pela autora da tese, cada pessoa é responsável pelo mundo.
} 
ao especialista melhor indicado, para que este, situando-se na peculiaridade do seu caso, disponha de melhores recursos para sanar a dificuldade ${ }^{1048}$. Porém, é preciso deixar muito claro ao seu pequeno mundo que, se os pais estão agora a lançar mão de outros recursos e o encaminham a outrem é porque o amam e têm a intencionalidade de deixá-lo sadio; porque o contrário seria um ato de desamor, seria compensar com algo material, ou abandoná-lo a outro, simplesmente, pela grande frustração de não ter conseguido lidar com as dificuldades do filho e com suas próprias dificuldades, o que também ficaria distante de ser a expressão simbólica do seu amor comprometido. E, assim como, muitas vezes, quando os pais não têm dinheiro para dar a seus filhos melhores presentes, mas sabem oferecer a eles uma bala, ou simplesmente tomá-los ao colo, ou ainda dar-lhes um sorriso, e isto vale muito mais do que brinquedos eletrônicos, ou outros que não tivessem a participação, ou envolvimento e a manifestação da ternura dos pais, assim, também, aqui. Se os pobres (necessitados de qualquer natureza), recorrem aos que vivem o seguimento de Cristo, e estes já não podem outra coisa, senão oferecer-lhes um ato de amor, de bondade, um sorriso, uma atenção, uma palavra de compreensão, ou conforto, às vezes, isso vale muito mais do que muita generosidade, sem amor verdadeiro. Por isso, é bom lembrar que a falta de entendimento, de condições pessoais, ou recursos para ajudar alguém, ou alguma situação, não justifica, em nada, a omissão dos cristãos.

É preciso ter em vista que a "Igreja não é uma realidade definitiva, mas apenas está a caminho em direção ao juízo de Deus. Trata (-se) antes de ser santa como o Deus que a chamou, para não comprometer o próprio testemunho ${ }^{\text {"1049 }}$.

Por isso nesta etapa, o amor não é falho, mas pleno, elevado. Este amor autêntico, cheio de Deus, vai tornando-se para o mundo um sinal que aponta para os valores celestes. E, ao mesmo tempo em que vai envolvendo e tocando a realidade na qual se situa, também vai elevando-a e dignificando-a, em Cristo. Aqui a pessoa está completamente unida a Deus e ao seu amor. O êxtase que se pode dar nesta etapa mostra uma superação e prepara o sujeito para avançar à morada da consciência mais ampla e ao grau de amor mais elevado. Aqui Teresa afirma: é a morada mais profunda. No fundo trata-se de algo que recai diretamente

${ }^{1048}$ Por encaminhar ao especialista compreenda-se o encaminhamento da situação, ou pessoa a alguém, a um sujeito ou a uma Instituição, melhor capacitada para ajudar o encaminhado a resolver suas dificuldades.

${ }^{1049}$ Cf. MISSAL COTIDIANO. Missal da Assembléia cristã. São Paulo: Paulus, 1985. p. 1245. 
sobre o núcleo da espiritualidade cristã. Impossível entendê-la esvaziando-se sua dimensão de mistério. Mistério que se contempla como Deus, em Deus, e mistério que se apresenta na vida, como falado no segundo capítulo ${ }^{1050}$. Mas o êxtase místico, quando transborda no humano não é para retê-lo no enlevo, mas para devolvê-lo novamente ao seu habitante, auxiliando-o a perceber as exigências da realidade que lhe é tão peculiar. De modo que aquele que está mais cheio de Deus, é o que também tem maior responsabilidade para levar, ao Senhor, os seus irmãos.

Aqui se volta à humanidade de Cristo. Para Teresa, a humanidade de Jesus constitui um centro insuplantável na vida cristã e estende seu influxo salvífico a todo o arco de crescimento da vida espiritual. Em cada cristão, em cada Igreja, inclusive ao cume da experiência mística. Assim

Cristocentrismo quer dizer que a fé e a vida cristã não estão fundadas em abstrações nem em filosofias, senão na existência singularíssima de uma pessoa histórica que se chama Jesus Cristo. Ele é o centro orbital de nossa vida, que é 'vida em Cristo'. Sim, fora dele a vida a vida se desordena. É isso a primeira coisa que Teresa quer dizer.

Assim, ao lançar-se à atividade apostólica é preciso ter consciência clara de que ela é fruto e extensão do amor de Deus; por isso mesmo, não dá para esquecer o seu primeiro amor, que é também a razão pela qual seus filhos estão aí. O filho mundo precisa ser amado e, também olhado com orgulho, pois dele os pais têm muita expectativa e, por isso, muito investem na esperança de quando crescer, a vida já esteja melhor e isso será a realização dos sonhos dos pais e também espelho e ideal para o sonho de muitas vidas futuras. De modo que aqui se vê que o amor tem a competência de criar a família real e a ideal. Porque só o amor constrói realmente o que é sólido e duradouro. É necessário refletir, para compreender bem qual é a solicitação mais profunda que, comumente está por trás dos seus aparentes pedidos, que geralmente perpassam nas entrelinhas de suas falas e, perguntar-se, intimamente: o que é que verdadeiramente está me pedindo este meu filho? Qual sua reivindicação mais profunda? É afeto, é presença, é atenção, é diálogo, é um testemunho de vida, de quê mesmo ele se encontra necessitado? Como posso atendê-lo da forma mais educativa e proveitosa? Talvez até seria importante perceber, ou rever-se se a própria relação com o Esposo está saudável, a quantas anda a consonância dessa relação com a vida e se, de fato, isso

${ }^{1050}$ Cf. ALVAREZ, T. Comentários a las Obras... p. 694. 
está favorecendo o desenvolvimento de seu pequeno mundo. Sendo este estágio onde há maior estabilidade e a pessoa alcançou o grau mais elevado de comunicação com Deus e entendimento do mundo, se for fiel ao seu relacionamento esponsal, não há dúvidas de que seus frutos serão de cem por um $^{1051}$. Contudo, quando os pais sentirem-se ameaçados, agredidos, injustamente interpretados, ou doloridos diante da ingratidão, do desamor e da imaturidade de seu filho, é bom lembrar: seu filho está em fase de transição, é adolescente, pode até ser "aborrrecente" mesmo! Pois o mundo ainda não amadureceu o suficiente para compreender as grandezas de Deus. Mas nada do que os pais fizerem, por amor a ele, será perdido! Podem os filhos não reconhecer este bem, neste momento, porque não estão preparados para isso, mas, cedo ou tarde, haverão de conhecer, porque o que foi plantado com amor sempre dá o seu fruto. A firmeza do olhar dos pais, que já compreendem a ternura do Amor de Deus e o sentido verdadeiro de cada existência, olhará para eles com amor e, sem amenizar a realidade da situação com palavras suaves e, sem calarem-se diante de tamanha desventura, ao evidenciar a eles suas faltas, irão, como profetas, anunciar-lhes as verdades do Evangelho, dando para isso a própria vida e o testemunho da autenticidade cristã.

E o filho mundo seguirá crescendo, tentando firmar-se em suas reivindicações por justiça. Está necessitado de saúde, às vezes passa fome, sua Educação está precária, o cuidado ecológico ainda não é suficiente, o aquecimento global o assusta, o futuro parece incerto, a corrupção que vê, por todos os lados, dói na alma, a política, à sua frente desconhece, em sua grande maioria, princípios básicos à vida. O filho mundo se questiona sobre tudo isso. Quer ser amado $e$ espera por seus pais! E, já não é sem tempo: “obras” quer o Senhor!

Por ser esta fase a fase em que vivamente tudo floresce e aparecem os frutos da entrega plena ao amor, pode-se chamar a esta de: fase da florescência.

${ }^{1051}$ Cf. Lc 8, 4-8. 


\section{5 \\ CONCLUSÃO}

Acredita-se que através do desenvolvimento desta tese, pôde-se provar que na obra do Castelo Interior de Teresa há um conceito de desenvolvimento humano subjacente. Este conceito entende que o desenvolvimento e a integração humana e espiritual basea-se no modelo da encarnação de Cristo que se faz referência de vida para todos. A pessoa em seu processo de crescimento humano e espiritual sente a necessidade de conhecer-se profundamente, de crescer e de se transcender no relacionamento com Deus e com os irmãos. Ao desenvolver-se, de forma adequada, humana e espiritualmente, naturalmente se sentirá chamada a se relacionar com Deus da vida e, progressivamente, irá saindo de seu narcisismo pessoal para ir ao encontro dos irmãos. À exemplo de Cristo, ao lançar-se em direção ao encontro de Deus e na direção dos irmãos, sua própria vida vai se tornando uma oração. À medida que se cristifica, consegue olhar para o alto, com os pés no chão da realidade que vive, sentindo-se interpelada à maturação, à ação, a ser sujeito de si mesma e da história.

Por sua sensibilidade e capacidade de amar, adentra ao mistério da vida, sendo solidária, sobretudo com os mais necessitados, pois sua maturação no amor, progressivamente delinea a presença do Cristo Vivo (Amor que se encarna) desde seu interior. Na docilidade da resposta aos impulsos da graça e na simplicidade do existir, sua vida vai se transformando em Cristo. Pela ação do Espírito Santo, vai se cristificando, "metarmofoseando-se": convertendo-se progressivamente ao amor. Nessa transformação e conversão profunda, ao deixar transparecer o referencial de sua vida que é Cristo, em cujo Modelo, revitaliza-se continuamente celebra seu viver e, atualiza constantemente o mistério de Cristo na vida da Igreja e na sociedade na qual se insere.

Assim, Teresa de Jesus, com sua mística, deixa para os cristãos e para a sociedade atual, um tesouro inigualável, com sólida doutrina de fé e com ricos e proveitosos ensinamentos para o desenvolvimento humano e espiritual. A capacidade de relacionar-se com Deus, grande dom que o Senhor dá a todos os seus filhos, mostra como, enquanto dom, a iniciativa da união é sempre de Deus. A pessoa é interpelada a crescer no relacionamento e na amizade com Ele e com os irmãos. E para isso, precisa dispor-se a "determinada determinação" de 
entregar sua vida à intimidade divina, aceitando as exigências desta relação e coadunando a vida a partir desse núcleo e referencial amoroso.

Desde o seio da Trindade, em seu amor infinito, Deus expande-se no esplendor de suas obras e, com todo o criado, estabelece uma comunicação. Faz isto porque é plenitude de ser e de vida e quer compartilhar desta imensidão de amor à extensão de Si. Entre todas as criaturas, escolhe o ser humano para ser a obra mais preciosa do seu grande amor. Fazendo-o à sua imagem e semelhança, propõe-se a formar com ele a sua grande família e estabelece, com seus filhos e filhas, um relacionamento fecundo de amizade, sustentado numa aliança de fidelidade permanente, por parte do Senhor, e na liberdade, por parte da pessoa.

Através desta via privilegiada da oração, o ser humano recebe de Deus todo o Seu amor e sua vida. A relação de amizade é participação na sua graça e na plenitude de Seu Ser. Comunica-lhe a capacidade de amar, através da ação do Espírito Santo e de Cristo. Quem acolhe a dádiva de Deus, responde com a adequação e ordenação dos valores de sua vida à finalidade de sua existência e pode contar-se uma pessoa realizada, pois no amor, na justiça e na paz, experiencia, já aqui na Terra, o que no céu irá viver com maior plenitude.

Jesus Cristo, o melhor Amigo, está sempre ao lado de cada pessoa, incentivando-a e elevando-a sempre mais. Sua fidelidade é o que a ampara e a anima a peregrinar rumo ao seu castelo interior. Prova com obras sua amizade e compromete-se com o ser humano, exigindo isso da parte dele também. Aquele que se envolve nessa amizade com Cristo, torna-se responsável pela honra e glória de Deus e deseja, que as palavras do Senhor tornem-se realidade para todas as pessoas, para a vida da Igreja e do mundo. É importante estar sempre unido a Cristo num vínculo estreito e deixar-se conduzir por Ele. A união, grau de intimidade que cada pessoa tem com o Senhor, distingue-a também na qualidade da relação com os irmãos, tornando-a um ser único, nos seus relacionamentos. Quem está intimamente unido a Cristo vive no mundo, está no mundo sem "ser do mundo". Ou seja, apresenta um nível de consciência espiritual e de conduta qualitativamente diferente de muitas das opções que a sociedade de hoje faz. Pois estando em Cristo, n'Ele vive em ardente caridade, buscando a justiça, o que é mais fraterno e o que melhor conduz a sociedade para um maior crescimento. A via privilegiada da oração ajudará o orante a desenvolver um relacionamento amoroso com Deus, a ponto de consagrar sua vida inteiramente a Ele e de 
perceber como na simbologia do cedro, que não apenas oferece os frutos da árvore para Deus, mas também a própria árvore, com raiz, caule, folhas, frutos e tudo o que ela comporta. Esta árvore por estar ligada à fonte da vida, ao dar os frutos de cem por um, proverá de todas as espécies frutos específicos para o cuidado com o filho mundo, para auxiliá-lo a uma transformação efetiva e eficaz. 


\section{CONCLUSÃO GERAL}

Iniciou-se esta tese com uma visão geral a respeito da vida e da obra de Teresa, compreendendo-a em seu contexto histórico, sócio-eclesial. Século de ouro, Espanha, onde há discriminação e exclusão, antissemitismo, impacto da Igreja, através do Index e da Inquisição. Concílio de Trento e rigorosos estatutos de limpeza de sangue que prejudicavam a mouros e judeus. Viu-se, também, esse século como um tempo de intensa sede de maior integração entre a vida e a fé. Século de muitas reformas, onde surgiram grandes reformadores e grandes santos: Lutero, Teresa, Inácio de Loyola, Francisco de Borja e Pedro de Alcântara, entre outros.

Apesar de, nessa época, a Igreja ser marcadamente masculina e se fazer ouvir pela força e, embora a mulher fosse relegada a uma condição ínfima, taxada de "mulherzinha", como rotularam a Teresa, sem vez, sem voz, sem direitos, numa cultura que não delegava espaços ao feminino, a contribuição de Teresa, com seus empreendimentos e, particularmente, através da sua mística, da sua criatividade, da sua sensibilidade e generosidade a colocaram muito à frente de seu tempo. Assim, Teresa não fica assujeitada ao papel e à posição que a sociedade lhe impõe. Não se acomoda, não se omite. Vai além. Fala por sua voz, fala por sua vida. Luta contra a inconsciência coletiva, no que diz respeito ao resgate da dignidade humana. Seus posicionamentos, sua empatia no diálogo e na inter-relação ultrapassam dogmatismos e barreiras. Por suas conquistas, por sua habilidade em lidar com tudo o que lhe cerca, torna-se modelo para o homem e para a mulher pós-moderna. Assim, pelo dom de sua feminilidade, pela riqueza da sua contribuição, Teresa não se faz apenas luz para as próximas gerações, mas unida à ação de Deus, tem a força de gerar, ainda mais vida. Deste modo, Teresa, mulher e mística, é canal da força da vida, que vem de Deus e que se torna sinal, eficaz para todos, de que é possível dar o melhor de si, pois dentro de cada um, há um potencial para a mudança.

Sua mensagem, suas obras e sua vida lembram que sempre é tempo de transformar-se a si mesmo, a partir de dentro, e ao mesmo tempo de transformar o contexto no qual se vive, em busca de um amanhã sempre melhor. Desta forma, Teresa é profeta e testemunha da força do misticismo e da vida autêntica que se 
legitima e se revitaliza no e como o ramo da videira, que pela infusão da graça divina, ao invés de secar, fica sempre verdejante e frutifica.

Viu-se, do mesmo modo, a gradativa busca de superação das concepções constratantes entre ciência e mística, o desejo de superação da relação corpo $e$ espírito, de sagrado e profano e de toda a concepção platônica da pessoa em seu ser, pensar, agir e experienciar. A problematização da ciência e da mística na história e na atualidade, com o aparecimento da consequente necessidade de se viver em profundidade o relacionamento interpessoal: da pessoa humana com a divina e dela com seus semelhantes. Observou-se os fenômenos extraordinários e ordinários e o discernimento dos mesmos. Percebeu-se que Teresa foi uma personalidade que se "ouviu" e que também pela graça de Deus, aprendeu a discernir. A psicologia nascente a diagnosticou como histérica, como alucinada, como louca, mas a própria história encarregou-se de purificar as arestas e de mostrar ao humano, o que de fato permanece. Hoje a ciência já compreende suas metáforas, busca sua sapiência e o diálogo com a essência de sua doutrina. Há até mesmo quem diga que Teresa deveria estar ao lado de Charcot, pois seria para ele um braço direito, essencial e fundamental como alavanca ao próprio desenvolvimento da psicologia. Mais que isto, o fato de ter vivido intensamente a sua mística a fez sentir-se, particularmente, introduzida numa vivência envolvente, enlevante e elevante da presença de Deus e, com Ele, em Cristo. Desde sua oração de quietude, desde a íntima união interior, sente-se movida a amar. Do momento inicial do apelo que recebeu de dedicar-se e empreender obras em favor dos irmãos e irmãs, já não deixou mais de responder ao Deus que mora no núcleo mais profundo de seu “castelo interior”, e desde lá a motiva à ação. Já não se importa mais com o que possam dizer a seu respeito. $O$ fato é que sabe que pode saborear no mais íntimo de si essa presença de Deus que a propulsiona à vida e ao serviço e que isso é o bem mais precioso de sua vida.

Por empreender essa relação de estreita amizade com Ele, perde a inclinação ao desordenado, ao mundano e centra-se no amor à Cristo. Ama afetiva, ativa e efetivamente aos irmãos e irmãs, na caridade. Descobre, assim, a mística como proposta existencial e, descobre-se a si mesma, como mística, unindo e vivenciando a própria vida, intimamente ligada à vida de Cristo, ressuscitado, vivo e presente na sua vida e na vida de seu povo. Do povo com o qual Ele sempre caminha junto, em comunhão. Sua experiência de vida e de oração são 
metanarrativas, para todos. De natureza mística, transcendem até mesmo a ciência em seu próprio sentido.

Quanto às questões de ética, moral e bioética, ao longo da história também foram firmando-se como objetos de discussão tanto para a psicologia, para a teologia, como também para a mística. E, de uma forma geral, as decisões e posturas das diferentes ciências são hoje respeitadas, mesmo em suas divergências principais, investindo-se no empenho e na capacidade de expressão de cada qual e no respeito do próprio desejo de se fazer ouvir e de se dar a compreender no âmbito das demais ciências.

Falou-se da psicologia, da psicanálise e de Freud, que ao mesmo tempo em que se declara como ateu, empenha seu tempo e sua juventude em refletir sobre a religiosidade. Quer mostrá-la como ilusão e aponta, como filho de seu tempo, que mais que tudo, a ciência e a razão são importantes. Contudo, por seu contexto e do seu jeito, ao investir em sua própria razão, de certa forma busca a Deus. Porque se pode investir tanto tempo em questionar-se sobre aquilo que pensa, isto é porque, de alguma forma, Deus significava algo para ele, também.

Pôde se perceber ainda, como a contribuição das religiões foram importantes para a organização do humano, das leis, das doutrinas e princípios. Assim, o conjunto de valores foi surgindo como norteador para a pessoa em relação à vida, à sua organização pessoal e à troca social e se colocou a serviço da pessoa e da sociedade.

Em Lacan contemplou-se que pela via da linguagem os significantes, independente da fé, também auxiliaram a organizar a vida e o modo de pensar do sujeito. O "eu" de Lacan tem a ver com o desconhecimento e com alienação (sede do narcisismo), como, acena Teresa às primeiras moradas. E, se para Teresa, no mais íntimo de si é onde mora Deus, pode-se considerar esse próprio inconsciente, como sua moradia. O que, posteriormente, também Jung afirmará. Para Lacan a pessoa se constitui, enquanto sujeito, tendo consciência de si mesma, a partir do Outro. O sujeito cartesiano, identificado simplesmente pelo eu racional, não podia colocar sua existência em dúvida, uma vez que o questionamento pressupunha o sujeito, por isso o: "Penso, logo, existo". Em Lacan, a capacidade de ser sujeito, ou de poder ser diferente do que se é, não depende da pessoa, mas dos outros, dado que se vive dentro de uma cultura, onde nela se faz as interações e os laços sociais. Assim é a cultura que auxilia o sujeito a ser ele próprio e, neste meio, a 
partir do outro, o sujeito assimila os próprios significantes e abandona suas máscaras, para firmar-se cada vez mais como sujeito, frente a si mesmo. Alienação é indicativo de sintoma, pois quem se aliena, veda para si o próprio agir, limitando para si mesmo a apropriação dos objetos da cultura e a relação.

A psicanálise de Jung deu passos longos em relação à mística. Seu inconsciente coletivo, seus significados simbólicos, que se fazem nas suas múltiplas conexões. Sua visão de conjunto e integração, tem tudo a ver com a necessidade de síntese da contemporaneidade e é próxima da mensagem teresiana.

A psicologia, servindo-se de sua análise, de seu discurso e de seu instrumental tem grande contribuição para o discernimento e desenvolvimento mística, dado qualificar-se por sua capacidade de ver, de ouvir, de perceber e, no uso de suas ferramentas principais: analisar, cuidar e tratar.

A procura de explicação sobre a vida e suas questões, encontra-se nas pessoas de todos os tempos e as respostas são buscadas desde a informalidade do saber, às verdades comprovadas cientificamente. Assim, a ciência, a Psicologia e a mística aparecem como colaboradoras para o processo de desenvolvimento humano e da sociedade e auxiliam as pessoas a darem significado e resolução às questões fundamentais e existenciais. Enquanto a ciência aponta caminhos para o aclaramento da verdade das questões, a mística mostra a profundidade e o significado para a vida de cada um. A ciência firma-se em seus critérios e a mística, renova-se nas expressões para que se perceba o caminho da vida e do amor, ensinados por Cristo, para maior e melhor humanização. Jesus Cristo, por sua encarnação revela o quanto o ser humano é amado e importante para Deus. Por isso, a pessoa, ao se espiritualizar, torna-se ainda mais humana, n'Ele se encontra a medida, a altura, a largura e a profundidade do quanto se pode amar a todos e a Deus.

Desta forma, a mística não é desencarnada e vazia, pois não há como se pensar Deus, sem pensar-se o humano, pois Deus, que se encarna no humano, também está na voz do povo que sofre e espera por maior libertação, toca-lhe e anda com Ele, num diálogo franco e aberto, pois “está vivo e entre nós”. Nessa direção, volta-se a lembrar a frase de Joseph Campbell: "Dizem que o que todos nós procuramos é um sentido para a vida. Não penso que seja assim. Penso que o que estamos procurando é uma experiência de estar vivos, de modo que nossas experiências de vida, no plano puramente físico, tenham ressonância no interior 
do nosso ser e de nossa realidade mais íntima, de modo que realmente sintamos o enlevo de estar vivos". Também, lembra-se a frase de Rahner, que se não for místico, "o homem do futuro não será nada". Ao que tudo indica, pelas buscas, pela sede e pelo dinamismo da pós-modernidade, as pessoas de hoje e do futuro, "serão, de fato, místicas"!

Assim o homem e a mulher, contemporâneos, fazem a experiência de serem pro-jetos, no sentido de incompletos, inacabados e no sentido histórico, do que se está fazendo ainda. Lançam-se, com abertura, em direção ao futuro, para o outro, para a vida e agora, como apontava Capra, procurando já um outro ponto de equilíbrio, mais dinâmico, que tolera e se ajusta aos opostos, num novo paradigma holístico, com um novo modo de integração.

A autonomia, a pertença, individual, ou em grupos, nas mais diversas comunidades eclesiais, a acolhida e a solidariedade fundamentadas na Pessoa, na vida e na obra de Cristo, auxiliam o humano a não procurar na emoção, no irracional, no sentimentalismo, aquilo e Aquele que estão para além de tudo isso. Assim, a imagem de Deus é algo que se modifica, ao longo da história, mas sua essência permanece, pois Cristo é o mesmo, ontem, hoje e sempre!

Assim, o Deus que fez o povo atravessar o exílio, é o mesmo que conduz hoje o povo passo-a-passo, acompanhando-o e fortalecendo-o em suas lutas e reivindicações. É o Deus que olha em direção ao homem pós-moderno e "escuta o seu clamor" de sentir-se atuante, protagonista e desejoso de ser sujeito da história. O povo mostra que Deus está junto dele e caminha com Ele, mais do que isso, faz-se um entre o povo. Por isso, o povo sente-se com maior força para reivindicar e assinalar que quer sua voz ouvida e atendida. Está consciente de que os que estão no poder, são "representação deste povo" e conhece seus direitos. Já "mostra a cara" e reivindica um novo tempo, com maior cuidado em relação à vida, em todas as suas etapas: às crianças, sobretudo, em melhorias escolares e no combate e erradicação da fome e da miséria, novos projetos, mais possibilidades de investimento na formação, na pesquisa, nos estágios, na qualidade de vida, habitação, transporte e emprego e, aos idosos, particularmente, no que diz respeito à saúde e a dignidade de viver. São reivindicações justas, necessárias, que precisam urgentemente de novas respostas e de novas reformas. Pois a vida e a fé, como diz Teresa "se coadunam". Não podem ser dicotomizadas. Precisam ser 
vividas na sua interação e na sua intensidade, pois a fé, quando legítima, se traduz em "obras", pois "obras quer o Senhor".

Assim, cabe ao homem e a mulher de hoje, transformar como na "metamorfose da borboleta" a esperança, o sonho e o ideal em realidade, em concretude. Pois, a mensagem da vida e da obra de Teresa, de sua mística, estão aí para lembrar que o povo que "espera em Deus" é o mesmo também, em unidade com o Deus da Vida e pela ação do Seu Espírito, tem a força de lutar e de transformar. Por isso, esse "Deus do povo", que o ama de um modo admirável, denomina-se de Deus Vivo! E, por "Deus da vida", quer ser conhecido, experienciado! O que o acolhe e segue desenvolvendo-se em seu relacionamento com Ele, nos diferentes processos e fases do desenvolvimento humano, encontrao, também, na sua própria luta, no mistério da vida, no próximo, no amor, na maternidade, na doação, nos encontros e reencontros existenciais, em tudo.

Que o momento histórico presente seja esta redescoberta do Amor, esta experiência da presença do Deus da vida, que se encontra "no centro da alma", mas também no irmão, no mistério existencial e nas lutas, propulsionando sempre à vida, ao amor e à justiça, como nos ensinou Teresa. 


\section{REFERÊNCIAS BIBLIOGRÁFICAS}

\section{Obras de referência de Teresa de Ávila}

SANTA TERESA. Escritos de Santa Teresa: Añadidos e ilustrados por Don Vicente de La Fuente Catedrático de Disciplina Eclesiástico en la Universidad de Madrid. Madrid: Rivadeneyra-Impressor- Editor, 1862. (Biblioteca de autores españoles desde la formación del linguaje hasta nuestros dias)

SANTA TERESA DE JESUS. Obras Completas. Alberto Barrientos (Dir.) 4. ed. Madrid: Editorial de Espiritualidad, 1994.

SANTA TERESA DE JESUS. Obras Completas. Preparada por Tomás Alvarez. 14. ed. Burgos: Editorial Monte Carmelo, 2006.

SANTA TERESA DE JESUS. Obras Completas. Revisada e anotada por Frei Tomás de La Cruz. Coordenação Frei Patrício Sciadini. 2. ed. São Paulo: Loyola, 2002.

Caminho de Perfeição. In: SANTA TERESA DE JESUS. Obras Completas. Revisada e anotada por Frei Tomás de La Cruz. Coordenação Frei Patrício Sciadini. 2. ed. São Paulo: Loyola, 2002. (Abreviada por C).

Cartas. In: SANTA TERESA DE JESUS. Obras Completas. Revisada e anotada por Frei Tomás de La Cruz. Coordenação Frei Patrício Sciadini. 2. ed. São Paulo: Loyola, 2002. (Abreviada por Cta.).

Castelo Interior ou Moradas. In: SANTA TERESA DE JESUS. Obras Completas. Revisada e anotada por Frei Tomás de La Cruz. Coordenação Frei Patrício Sciadini. 2. ed. São Paulo: Loyola, 2002. (Abreviada por M).

Conceitos do Amor de Deus. In: SANTA TERESA DE JESUS. Obras Completas. Revisada e anotada por Frei Tomás de La Cruz. Coordenação Frei Patrício Sciadini. 2. ed. São Paulo: Loyola, 2002. (Abreviada por CAM).

- Fundações. In: SANTA TERESA DE JESUS. Obras Completas. Revisada e anotada por Frei Tomás de La Cruz. Coordenação Frei Patrício Sciadini. 2. ed. São Paulo: Loyola, 2002. (Abreviada por F).

Livro da Vida. In: SANTA TERESA DE JESUS. Obras Completas. Revisada e anotada por Frei Tomás de La Cruz. Coordenação Frei Patrício Sciadini. 2. ed. São Paulo: Loyola, 2002. (Abreviada por V). 
Poesias. In: SANTA TERESA DE JESUS. Obras Completas. Revisada e anotada por Frei Tomás de La Cruz. Coordenação Frei Patrício Sciadini. 2. ed. São Paulo: Loyola, 2002. (Abreviada por P).

Relações. In: SANTA TERESA DE JESUS. Obras Completas. Revisada e anotada por Frei Tomás de La Cruz. Coordenação Frei Patrício Sciadini. 2. ed. São Paulo: Loyola, 2002. (Abreviada por R).

\section{Obras sobre mística teresiana}

ÁLVAREZ, A. S. Castillo Interior: Camino hacia el encuentro con Dios con Santa Teresa de Jesús. Burgos: Editorial Monte Carmelo, 2001.

ALVAREZ, T. Comentarios a las Obras de Santa Teresa "Libro de la Vida", “Camino de Perfección” y "Castillo Interior": Para la reflexión y oración personal y de grupo. Burgos: Editorial Monte Carmelo, 2005.

Estudios Teresianos Biografia e História. vol. I. Burgos: Editorial Monte Carmelo, 2000. (Coleção Biblioteca Mística Carmelitana).

Guia al Interior del Castillo: Lectura espiritual de las Moradas: Burgos: Editorial Monte Carmelo, 2000.

Teresa a contraluz: La Santa ante la crítica. Burgos: Ed. Monte Carmelo, 2004.

AUCLAIR, M. Prólogo da versão francesa do livro das fundações, París 1952. Apud ALVAREZ, Tomás. Teresa a contraluz: La Santa ante la crítica. Burgos: Ed. Monte Carmelo, 2004.

Teresa de Ávila: a dama errante de Deus. São Paulo: Quadrante, 1995.

BALLESTER. Introducción a Santa Teresa de Jesús. Apud SANTOS, L.L. Fémina Inquieta y Andariega: Valores e Símbolos da literatura cavaleiresca nos escritos de Santa Teresa de Jesús (15-15-1582). Dissertação (Mestrado) - Porto Alegre: Universidade Federal do RS, Instituto de Filosofia e Ciências Humanas, 2006.

BIBLIOTECA MÍSTICA CARMELITANA (BMC). Procesos de beatificación y Canonización de Santa Teresa de Jesús. Burgos: Monte Carmelo, 1935. 3 Tomos. BMC 18,19 e 20. Editados e anotados por Frei Silvério de Santa Teresa.

BURGO, L; NAVARRO, E. G.; GUERRA, A. Para leer a Santa Teresa. Santo Domingo: Monte Carmelo/Editorial de Espiritualidad del Caribe, 1994. 
CARMELITAS do Convento de Santa Teresa do Rio de Janeiro. Santa Teresa de Jesus: Moradas, Caminhos. Por ocasião do IV Centenário da morte da Doutora Mística 1582-1982. Rio de Janeiro: Cartas Marco’s, 1981.

CASTANHEIRA AVELAR, M. C; RUBIO, A. G. Experiência mística e comunicação teológica: estudo sobre o estilo pedagógico da Teologia de Teresa de Jesus, na "Vida", no "Caminho" e no "Castelo Interior". 2 v. Tese (Doutorado) - Rio de Janeiro: Pontifícia Universidade Católica do Rio de Janeiro, Departamento de Teologia, 1998.

EGIDO MARTINEZ. T; GARCIA DE LA CONCHA, GONZALES DE CARDEDAL, O. (Orgs.) Actas del Congresso Internacional Teresiano. vol I. Salamanca, 1983.

ELLIS, H. The soul of Spain. Boston: [s.e], 1915.

GARCIA, C. Santa Teresa de Jesus: Nuevas Claves de lectura. Burgos: Monte Carmelo, 1998. (Colección Karmel, n. 38).

HERRAIZ-GARCIA, M. Oração: história de amizade. Apresentação Frei Patrício Sciadini. 2. ed. São Paulo: Loyola, 2002.

Teresa de Jesús Testigo y Maestra de Oración. Instituto de Espiritualidad a Distancia Adscrito al Teresianum de Roma. Madrid: [s.d]. Cuadernos de Espiritualidad. n. 3.

LLAMAS-MARTINEZ, E. Teresa de Jesús y los alumbrados. Hacia una revisón del 'alumbradismo' español del siglo XVI. In: EGIDO MARTINEZ. T; GARCIA DE LA CONCHA, GONZALES DE CARDEDAL, O. (Orgs.) Actas del Congresso Internacional Teresiano. vol I. Salamanca, 1983.

MELÚS, R. M. L. Santa Teresa de Jesus. Reformadora do Carmelo, n. 3. Espanha: CESCA (Centro de Espiritualidad Carmelitana), 1978.

MONTALVA, E.; BARRIENTOS, A. Introducción a la lectura de Santa Teresa. Madrid: Editorial de Espiritualidad, 1978.

PEDROSA-PADUA, L. "Eminentemente humana e toda de Deus": Uma leitura antropológica do "Castelo Interior ou Moradas" de Teresa de Jesus. Dissertação de Mestrado. Pontifícia Universidade Católica do Rio de Janeiro, 1995.

Espiritualidade integradora: o testemunho privilegiado de Santa Teresa de Ávila. In: GARCIA RUBIO, A. (Org.). O humano integrado: abordagens de Antropologia Teológica. Petrópolis: Vozes, 2007. 
O Mistério de Deus em Santa Teresa: Experiência do mistério trinitário na obra de Teresa de Jesus. 2 v. Tese (Doutorado). Pontifícia Universidade Católica do Rio de Janeiro, Departamento de Teologia, 2001.

PEDROSA-PÁDUA, L.; CAMPOS, M. (Orgs.). Santa Teresa: Mística para o nosso tempo. São Paulo/ Rio de Janeiro: Reflexão/PUC-Rio, 2011.

PEREZ, J. Teresa de Ávila: y la Spanã de su tiempo. Madrid: Algaba Ediciones, 2007.

REYNAUD, E. Teresa de Ávila ou o Divino prazer. 2. ed. Rio de Janeiro/São Paulo: Record, 2001.

RIBEIRA, F. Vida de Santa Teresa de Jesus. 3. ed. Barcelona: Gustavo Gili Editor, 1908.

RUANO, A. La psicologia de Santa Teresa: posturas, feminismo, elegância. La psicología de Santa Teresa. Posturas. Feminismo. [s.1.]: Estúdios del Colégio filosófico "La Santa”, 1950.

RUIZ, A. Así era Teresa. Burgos: Editorial Monte Carmelo, 1982.

SANCHEZ-CARO, J. Intimidad y misticismo en Teresa de Jesús. Ávila: Institución "Gran Duque de Alba" de la Excma. Diputación de Ávila, 2005. (Colección "Monografías literárias" n. 5)

SANROMÁN, J. B. Anteriores Centenários de la muerte de Santa Teresa. Revista de Espiritualidad: Santa Teresa en su ambiente histórico. Madrid: vol. 40. n. $159-160,1982$.

SANTO AGOSTINHO. Apud CEI- Itaici. Rabi onde moras: Roteiro para uma oração e vida ao longo do noviciado. 3. ed. São Paulo: Loyola, 1996.

SANTOS, L. L. Fémina Inquieta y Andariega: Valores e Símbolos da literatura cavaleiresca nos escritos de Santa Teresa de Jesús (15-15-1582). Dissertação (Mestrado) - Porto Alegre: Universidade Federal do RS, Instituto de Filosofia e Ciências Humanas, 2006.

SCIADINI, P. Santa Teresa de A a Z. São Paulo: Loyola, 2004. Teresa d'Avila. São Paulo: Salesiana Dom Bosco, 1982.(Coleção Heróis n. 21).

STEGGINK, O.; EFREN DE L.M.D. Tiempo y vida de Santa Teresa. 2. ed. Madrid: BAC, 1977.

WEBER, A. Teresa of Avila and the Rhetoric of Feminity. New Jersey. Princeton: University Press, 1996. 
WISEMAN, N. P. The Revelations of St. Theresa. In: The Dublin Reviev. Califórnia: Burns and Oates, 1884.

\section{Obras de Teologia}

AARON, N. G. Thought and poetic structure In San Juan De la Cruz's. Germany: Peter Lang Publishing, 2005.

A BÍBLIA DE JERUSALÉM. Tradução da Vulgata de Jerônimo, 347-419 d.C. 7. ed. São Paulo: Paulus, 1995.

ALAIZ, A. O valor da amizade. 3. ed. São Paulo: Paulinas, 1986.

BARREIRO, A. Buscar a Deus e encontrar-se em Deus: Como orar no mundo de hoje. São Paulo: Loyola, 1995.

BARRY, W. A. Deus e você: A oração como um relacionamento pessoal. São Paulo: Loyola, 1998.

BARRY, W.; CANNOLLY, W. Prática da direção espiritual. 3. ed. São Paulo: Loyola, 1999.

BINGEMER, M. C. L. As grandes formas da experiência mística na tradição ocidental. In: BINGEMER, M. C. L.; BHARTOLLO JR. R. S. (Orgs.) Mística e Política. Seminários especiais Centro João XXIII. São Paulo: Loyola, 1994.

BINGeMER, M. C. L.; BHARTOllo JR. R. S. (Orgs.) Mística e Política. Seminários especiais Centro João XXIII. São Paulo: Loyola, 1994.

BOFF, L. Atualidade da Experiência de Deus. Rio de Janeiro: CRB, 1974.

BOFF, L; FREI BETO. Mística e espiritualidade. 6. ed. Rio de Janeiro: Garamond, 2005.

BOFF, L. O visível e o invisível. In: BOFF, L.; FREI BETO. Mística $e$ espiritualidade. 6. ed. Rio de Janeiro: Garamond, 2005.

CABARRÚS, C. R. Crescer bebendo do próprio poço. 2. ed. São Paulo: Loyola, 2004.

CATALÁN, J. O. Experiência mística e suas expressões. São Paulo: Loyola, 2008.

CATECISMO DA IGREJA CATÓLICA Petrópolis/São Paulo: Vozes/Loyola, 1993.

CAVALCANTI, R. O Retorno do Sagrado: a reconciliação entre Ciência e Espiritualidade. São Paulo: Cultrix, 2000. 
COLLINS, M.; PRICE, M. História do Cristianismo: 2000 anos de fé. São Paulo: Loyola, 1994.

COMPÊNDIO VATICANO II, Constituições, Decretos, Declarações. 26 ed. Petrópolis: 1997. Constituição Lumen Gentium. 26 ed. Petrópolis: 1997.

CONGAR, Y. Diálogos de outono Igreja e Papado: perspectivas históricas. São Paulo: Loyola, 1997.

DIMENSÃO BIBLICO-CATEQUÉTICA ARQUIDIOCESE DE SÃO PAULO. O fenômeno religioso: diálogo entre diferentes. São Paulo: Loyola, 1997. DOCUMENTOS DO CONCÍlIO VATICANO II. Constituição Dogmática Lumen Gentium Sobre a Igreja. São Paulo: Paulus: 2001.

DOMINGUEZ MORANO, C. Crer depois de Freud. Tradução de Eduardo Dias Gontijo. São Paulo: Loyola, 2003.

FIDES ET RATIO. Carta Encíclica do Sumo Pontífice João Paulo II aos Bispos da Igreja Católica sobre as relações entre fé e razão. São Paulo: Edições Paulinas, 1998.

FRANÇA MIRANDA, M. A Igreja numa sociedade fragmentada: escritos teológicos. São Paulo: Loyola, 2006.

FREI BETTO. Prefácio. In: BOFF, L.; FREI BETO. Mística e espiritualidade. 6. ed. Rio de Janeiro: Garamond, 2005.

FUNDACIÓN NUEVAMÉRICA, CONSEJO DE CULTURA A. L. La radicalidade de una utopia: Pedro Poveda desde América. Argentina: Buenos Aires, 1993. (Cuadernos Nuevamérica. n. 4).

GALILEA, S. As raízes da espiritualidade latino-americana: os místicos ibéricos. Tradução Luiz João Gaio; revisão Eliane Henrique Nunes. Farias. São Paulo: Paulinas, 1984.

GAYANGOS, P. La gran conquista de Ultramar. Madrid: M. Rivadeneyra Impressor, 1958.

GARCIA RUBIO, A. (Org.). O humano integrado: abordagens de Antropologia Teológica. Petrópolis: Vozes, 2007.

GILBERT, P. P. Introdução à teologia medieval. São Paulo: Loyola, 1999.

HACKMANN, G. L. B. Jesus Cristo, nosso Redentor: Iniciação à Cristologia como Soteriologia. 2. ed. Porto Alegre: EDIPUCRS, 1999.

HARO, P. A. La sublimidade y lo sublime. Madrid: editorial Verbum, S.L., 2006. 
HORTAL, J. (S.J). E, haverá um só rebanho: história, doutrina e prática católica do ecumenismo. 2. ed. São Paulo: Loyola, 1989.

JOÃO PAULO II. Carta Encíclica. Dominum et Vivificantem: O Espírito Santo na Vida da Igreja e do mundo. n. 34. São Paulo: Loyola, 1986.

KEATING, T. Mente aberta, coração aberto: a dimensão contemplativa do evangelho. São Paulo: Loyola, 2005.

KLOPPENBURG, B.. Virtudes: frutos que o Pai espera. Petrópolis: Vozes, 2001.

KRIPAL, J. J. Roads of excess, palaces of wisdom: eroticism and reflexivity in the study of mysticism. Chicago: The University of Chicago. 1962.

KUNG, H. Por que ainda ser cristão hoje? Campinas: Versus, 2004. Religiosidade, espiritualidade, mística. In: LIBANIO, J. B. A religião no início do milênio. São Paulo: Loyola, 2002.

LAFRANCE, J. Reza ao Pai em teu íntimo. São Paulo: Loyola, 1995.

LIBANIO, J. B. A religião no início do milênio. São Paulo: Loyola, 2002. . Eu creio, nós cremos: tratado da fé. 2. ed. São Paulo: Loyola, 2004. Jovens em tempos de Pós Modernidade: considerações sócio-culturais e pastorais. São Paulo: Loyola, 2004. Os carismas na Igreja do Terceiro Milênio: Discernimento, desafio e práxis. São Paulo: Loyola, 2007.

LIBANIO J. B; MURAD, A. Introdução à Teologia: perfil, enfoques, tarefas. São Paulo: Loyola, 1996.

MARTINETTI, G. Razões para crer. São Paulo: Loyola, 1995.

MARY THERESE, S. Heroes and heroines Canonized in the twentieth Century: Book II (1951-1999). United States of America: Indiana, 2009.

MEZAN, R. A Sombra de Dom Juan e outros ensaios. 2. ed. São Paulo: Casa do Psicólogo, 2005.

MILLER, J. Um esforço de poesia. Apud NUNES JUNIOR, A. B. Exxtase e clausura: sujeito místico, psicanálise e estética. São Paulo Annablume, 2005.

MISSAL COTIDIANO. Missal da Assembléia cristã. São Paulo: Paulus, 1985.

MOHAMA, J. Ajustamento conjugal. São Paulo: Loyola, 2004.

A vida sexual dos solteiros e dos casados. 3. ed. São Paulo: Loyola, 2002.

MOURRET, F. A history of the Catholic Church. vol. 5. Translation por Rev Newton Thompson. [s.1.] Herder, 1946-1957. 
NUNES JUNIOR, A. B. Exxtase e clausura: sujeito místico, psicanálise e estética. São Paulo Annablume, 2005.

O'CONNELL, M. R. Critics on Trial: An Introduction to the catholic Modernist Crisis. United States of América: Liberary if Cibgress Catalogin. [s.d].

OLIVEIRA, J. L. M. Viver os votos em tempos de Pós-Modernidade. 2. ed. Rio de Janeiro: Loyola, 2002.

OTTO, R. O aspecto "Mistéryum", o "totalmente Outro". In: OTTO, R. O Sagrado: os aspectos irracionais na noção do divino e sua relação com o racional. Tradução de Walter O. Schlupp. São Leopoldo: Sinodal/EST; Petrópolis: Vozes, 2007.

PEDROSA, L. P. Evolucionismo e espiritualidade: contribuições da mística par uma revisão da imagem de Deus. In: RUBIO, A. G; AMADO, J. P. (Orgs). Fé Cristã e Pensamento Evolucionista: Aproximações Teológico-Pastorais a um tema desafiador. São Paulo: Paulinas, 2012. (Coleção Alternativas).

PIERRARD, P. História da Igreja. Tradução de Álvaro Cunha. São Paulo: Paulinas, 1982.

RAHNER, K. Elementos de espiritualidad en la iglesia del futuro. Apud GOFFI, T.; SECONDIN, B.; Problemas y perspectivas de espiritualidad. Salamanca: Sígueme, 1969.

RAMPAZZO, L. Antropologia, Religiões e Valores cristãos. 3. ed. São Paulo: Loyola, 2004.

RICOUER, P. Apud GUIMARÃES, A. E. A paternidade no confronto entre psicanálise da religião e fé. Porto Alegre: EDIPUCRS, 1999.

RUBIO, A. G; AMADO, J. P. (Orgs). Fé Cristã e Pensamento Evolucionista: Aproximações Teológico-Pastorais a um tema desafiador. São Paulo: Paulinas, 2012. (Coleção Alternativas).

RUBIO, A. G. Nova Evangelização e maturidade afetiva. São Paulo: Paulinas, 1993. (Coleção estudos e debates latino-americanos).

RUIZ SALVADOR, F. Compêndio de Teologia Espiritual. Título original: Caminos del espíritu. Revisão Célia Regina Faria Menin; Sandra Garcia. São Paulo: Loyola. 1996.

SANTO AGOSTINHO. Apud CEI- Itaici. Rabi onde moras: Roteiro para uma oração e vida ao longo do noviciado. 3. ed. São Paulo: Loyola, 1996.

SÃO JOÃO DA CRUZ. Obras Completas. 6. ed. Petrópolis: Vozes, 2000. 
Ditos de luz e de amor. n. 101. In: SÃO JOÃO DA CRUZ. Obras Completas. 6. ed. Petrópolis: Vozes, 2000.

. Poesias. In: Obras Completas. 6. ed. Petrópolis: Vozes, 2000. Romance 2.

SCIADINI, P. Mística e Compromisso: Pistas para dias de deserto. São Paulo: Loyola, 1989.

SHELDRAKE, P. Espiritualidade e Teologia: Vida Cristã e fé Trinitária. Tradução de Ricardo Gouveia. São Paulo: Paulinas: 2005. (Coleção Teologia no Espírito).

SCHIAVO, L. Mística e Pós-Modernidade: Culturas, Sociedade e religião. Goiás: UCG, 2005.

SCHICKENDANTZ, C. F. Karl Rahner: Una fuente de inspiración. Projeto. v. 42. Documento de Trabalho. Córdoba: Universidad Catolica Secretaría de Investigación y Posgrado, 2002. (Filosofía y humanidades).

SUDBRAK, J. Mística: a busca do sentido e a experiência do absoluto. São Paulo: Loyola, 2007.

. Mística cristã. In: GOFFI, T; SECONDIN, B. (Orgs.) Problemas e perspectivas de espiritualidade. São Paulo: Loyola, 2002.

SUSIN, L.C. Jesus Filho de Deus e Filho de Maria. Ensaio de Cristologia Narrativa". 2. ed. São Paulo: Paulinas, 2002.

TEIXEIRA, E. F. B.; MÜLLER, M.C.; SILVA, J. D. T. (Orgs.). Espiritualidade e Qualidade de Vida. Porto Alegre: EDIPUCRS, 2004. (Coleção Filosofia, 11).

TERRIN, A. N. Nova Era: a religiosidade do pós-moderno. São Paulo: Loyola, 2006.

TOMÁS DE AQUINO, S. Suma Teológica I. Tradução e direção Pe. Gabriel C. Galache. 2. ed. São Paulo: Loyola, 2001.

TORRES SANCHEZ, C. La Salamanca clausura feminina en la del siglo XVII: domenicas y carmelitas Salamanca: Ediciones Universidad, 1991.

Mística y cristología en Santa Teresa. In: CASTRO, S. (Org.). Teresa de Jesús. Presencia Permanente. Revista de Espiritualidad. n. 222-223. ene/jun. Madrid, 1997.

VAZ, H. C. L. Experiência mística e filosofia na tradição ocidental. São Paulo: Loyola, 2000. 
Relação entre mística e fenômenos atuais. In: BINGEMER, M. C. L.; BHARTOLlO JR. R. S. (Orgs.) Mística e Política. Seminários especiais Centro João XXIII. São Paulo: Loyola, 1994.

VELASCO, M. El fenómeno místico. Madrid: Editorial Trotta S.A, 1999.

ZILLES, U. Criação ou evolução? 2. ed. Porto Alegre: EDIPUCRS, 1995. . Espiritualidade cristã. In: TEIXEIRA, E. F. B.; MÜLLER, M.C.; SILVA, J. D. T. (Orgs.). Espiritualidade e Qualidade de Vida. Porto Alegre: EDIPUCRS, 2004. (Coleção Filosofia, 11).

. O racional e o místico em Wittgenstein. 3. ed. Porto Alegre: . Pierre Teilhard de Chardin: ciência e fé. Porto Alegre: EDIPUCRS, 2001.

ZOLLA, E. Los místicos de Occidente I: mundo antíguo, pagano y Cristiano. Traducción de José Pedro Tosaus Abadía. Barcelona: Ediciones Paidós Ibérica, 2000 .

\section{Obras de Psicologia}

ALONSO, S. L.; FUKS, M. P. Histeria: clínica psicanalítica. São Paulo: Casa do Psicólogo, 2004.

ANACLETO, W. A psicanálise e a religião: Inimigas, ou parceiras? São Paulo: Biblioteca 24x7, 2009.

ANDERSON, O. Freud precursor de Freud: estudos sobre a pré-história da psicanálise. Introdução de Elisabeth Roudinesco, Per Magnus Johasson; tradução Luiz Carlos Uchôa Junqueira Fo. São Paulo: Casa do Psicólogo, 2000.

ARTAUD, G. Conhecer-se a si mesmo: Crise de Identidade do adulto. 4 ed. São Paulo: Paulinas, 1982.

ÁVILA. A. Para conocer la psicologia da religión. São Paulo: Loyola, 2007.

BONAVENTURE, L. Psicologia e vida mística: contribuição para uma psicologia cristã. Petrópolis: Vozes, 1996.

CAMARA, M. V. Reich: grupos e sociedade. São Paulo: Annablume, 2009.

CAUDILL, M. A. Controle a dor, antes que ela assuma o controle: um programa clinicamente comprovado. Tradução de Denise Maria Bolanho. São Paulo: Summus, 1998.

CENCINI, A.; MANENTI, A. Psicologia e Formação: Estruturas e Dinamismos. São Paulo: Paulinas, 1988. 
CHAVES, J. A compreensão da pessoa: Psicologia da Personalidade. São Paulo: Editora Ágora, 1992.

DALGALARRONDO, P. Psicopatologia e semiologia dos transtornos mentais. 2. ed. Porto Alegre: Artmed, 2008. Religião, psicopatologia e saúde mental. Porto Alegre: Artmed, 2008.

DOWNING, C. (Org). Espelhos do Self: As Imagens Arqutípicas que Moldam a sua Vida. São Paulo: Cultrix, 1994.

ELIA, L. O conceito de sujeito. 3. ed. Rio de Janeiro: Zahar, 2010.

FINKLER, P. Porquê sou psicólogo humanista? Porto Alegre: EDIPUC, 2000.

FRANKL, V. Apud FINKLER, P. Porquê sou psicólogo humanista? Porto Alegre: EDIPUC, 2000.

Psicoterapia e sentido da vida. São Paulo: Quadrante; 1973.

FREUD, S. O futuro de uma ilusão. Tradução de José Octávio de Aguiar Abreu. Rio de Janeiro: Imago, 1997 (1927). Totem e Tabu. Rio de Janeiro: Imago /Ed. Standard Brasileira das Obras Psicológicas Completas de Sigmund Freud. vol. XIII, 1974.

GIOVANETTI, J. P. Psicologia e senso religioso: a necessidade e o desejo, modalidade da época. In: PAIVA, G. J. et al. Entre a necessidade e desejo: diálogos da Psicologia com religião. São Paulo: Loyola, 2001.

GOLDIFARB, D. C. Demências: clínica psicanalítica. São Paulo: Casa do psicólogo, 2004. (Coleção clínica psicanalítica, dirigida por Flávio Carvalho Ferraz).

GOMES, M. R. Repetição e diferenças nas reflexões sobre comunicação. São Paulo: Anna Blume, 2001.

GUIMARÃES, A. E. A paternidade no confronto entre psicanálise da religião e fé. Porto Alegre: EDIPUCRS, 1999.

HALL, C. S.; NORDBY, V. J. Introdução à Psicologia Junguiana. Tradução de Heloysa de Lima Dantas. 8. ed. São Paulo: Cultrix, 2005.

HALL, J. A.; CABRAL, A. Jung e a interpretação dos sonhos: manual de teoria e prática. 9. ed. São Paulo: Cultrix, 2005. (Coleção estudos de Psicologia Junguiana por Analistas Junguianos).

JOHNSON, R. A. A chave do entendimento da Psicologia Feminina: Uma interpretação baseada no mito de Eros e Psique, usando conceitos psicológicos jungianos. São Paulo: Mercuryo, 1987. 
JUNG, C. G. Apud SAIANI, C. Jung e a educação: uma análise da relação professor/aluno. São Paulo: Escrituras Editora, 2000. (Série ensaios transversais). O homem e seus símbolos. Rio de Janeiro: Nova Fronteira, 1964.

KRIPAL, J. J. Roads of excess, palaces of wisdom: eroticism and reflexivity in the study of mysticism. Chicago: The University of Chicago. 1962.

LACAN, J. O Seminário, Livro 3: As psicoses. Rio de Janeiro: Jorge Zahar, 1988. O seminário, livro 20: Mais, ainda. Rio de Janeiro: Jorge Zahar, 1985.

LEITE, D. M. (Org.). Estudos em Psicologia. São Paulo: Editora UNESP, 2009.

MACEDO, M. M. K. A caça às bruxas: a Idade Média e a histeria. In: MACEDO, M. M. K. (Org.). et. al. Neurose: Leituras psicanalíticas. 2. ed. Porto Alegre: EDIPUCRS, 2005.

MALDONADO, M. T. Vida em Família: Conversa entre pais e filhos. 4 ed. São Paulo: Saraiva, 1996.

MILLER, J. A. Algumas reflexões sobre o fenômeno psicossomático. In: WARTEL, R. Psicossomática e Psicanálise. Rio de Janeiro: Jorge Zahar, 1990. ORAZIO, M.J. Convite a ler Teresa. Apud VASSE, D. Leitura psicanalítica de Teresa de Ávila. Tradução Nadyr de Salles Penteado. São Paulo: Loyola, 1994. PAIVA, G. J. A religião dos cientistas: uma leitura psicológica. São Paulo: Loyola, 2000.

PAIVA, G. J. (Org.). et. al. Entre necessidade e desejo: diálogo entre psicologia e religião. São Paulo: Loyola, 2001.

PLATÃO. Apud SILVA JR. N.; FERRAZ, F. Linguagens e pensamento: a lógica na razão e na desrazão. Coleção clínica psicanalítica. São Paulo: Casa do Psicólogo, 2007.

QUINET, A. Um olhar a mais: ver e ser visto na psicanálise. 2. ed. Rio de Janeiro: Jorge Zahar, 2004.

RIDICK, J. Os votos um tesouro em vasos de argila: Reflexões psicológico espirituais. São Paulo: Paulinas, 1986.

RIZZUTO, A. M. O nascimento do Deus vivo: um estudo psicanalítico. Tradução Geraldo Korndörfer. São Leopoldo: Sinodal/EST, 2006.

THA, F. Categorias conceituais da subjetividade. São Paulo: Annablume, 2007.

TURKENICZ, A. A aventura do casal: Uma abordagem teórico-clínica. Porto Alegre: Artes Médicas, 1995. 
VASSE, D. Leitura psicanalítica de Teresa de Ávila. Tradução Nadyr de Salles Penteado. São Paulo: Loyola, 1994.

VERGOTE, A. Necessidade e desejo da religião na ótica da psicologia. In: PAIVA, G. J. (Org.) et. al. Entre necessidade e desejo: diálogo entre psicologia e religião. São Paulo: Loyola, 2001.

ZIMERMAN, D. E. Os quatro vínculos: amor, ódio, conhecimento e reconhecimento na psicanálise e em nossas vidas. Porto Alegre: Artmed, 2010.

Psicanálise em perguntas e respostas: verdades, mitos e tabus. Porto

Alegre: Artmed, 2007.

WARTEL, R. Psicossomática e Psicanálise. Rio de Janeiro: Jorge Zahar, 1990.

WEBSTER, R. Por que Freud errou: pecado, ciência e psicanálise. Tradução de Alda Porto. Rio de Janeiro: Record, 1999.

WELCH, J. Peregrinos espirituales: Carl Jung y Teresa de Jesús. Traducción: María del Carmen Blanco Moreno y Ramón Alfonso Díez Aragón. Bilbao: Desclée de Bouwer 2001. (Caminos 25).

\section{Obras Diversas}

ALVES, P. M. S. Fenomenologia: a metafísica do método. In: FERRER, D. (Org.). Método e métodos do pensamento filosófico. Coimbra: Imprensa da Universidade de Coimbra, 2007.

ANDRADE, A. L. O que vem a ser sistêmico. In: ANDRADE, A. L. (Org.). et. al. Pensamento sistêmico: caderno de campo. O desafio da mudança sustentada nas organizações e na sociedade. Porto Alegre: Bookman, 2006.

ANDRADE, A. L. (Org.). et. al. Pensamento sistêmico: caderno de campo. O desafio da mudança sustentada nas organizações e na sociedade. Porto Alegre: Bookman, 2006.

BATISTA, W. Ética e contemporaneidade: sujeito e destruição do destino. In: KOSOVSKI, E; BARATA, A. et. al. Ética na comunicação. Rio de Janeiro: MAUAD, 1995.

BENÍTEZ, H. René Descartes: entre la razón y la fe. In: Ensaios de ciência e religião: de Giordano Bruno a Charles Darwin. Santiago: RIL Editores, 2011. BRAGA, T. Historia do theatro portuguez. Porto: Editora Imprensa Portuguesa, 1870 . 
BRAKEMEIER, G. Ciência ou religião, quem vai conduzir a história? São Leopoldo: Sinodal, 2006.

CAMBI F. História da Pedagogia. Tradução de Álvaro Lorencini. São Paulo: Fundação Editora da UNESP/FEU, 1999.

CAPRA, F. A teia da vida: Uma nova compreensão científica dos sistemas humanos. São Paulo: Cultrix, 1996.

$O$ ponto de mutação: a ciência a sociedade e a cultura emergente. Tradução Álvaro Cabral. São Paulo: Cultrix, 2006.

CAVALCANTI, R. O retorno do sagrado: Reconciliação entre ciência e espiritualidade. São Paulo: Cultrix, 2005.

COSTA, D. Fundamentos para o estudo da estratégia nacional. Rio de Janeiro: Paz e Terra, 2009.

DESCARTES. Apud BENÍTEZ, H. René Descartes: entre la razón y la fe. In: Ensaios de ciência e religião: de Giordano Bruno a Charles Darwin. Santiago: RIL Editores, 2011.p. 151.

FERRER, D. (Org.). Método e métodos do pensamento filosófico. Coimbra: Imprensa da Universidade de Coimbra, 2007.

GAYANGOS, P. La gran conquista de Ultramar. Madrid: M. Rivadeneyra Impressor, 1958.

GIBRAN, K. G. O profeta: Texto Integral. São Paulo: Martin Claret, 2003.

JORGE, J. S. Cultura religiosa: O homem e o fenômeno religioso. 2. ed. São Paulo: Loyola, 1998.

KLEIN. Apud BARREIRA, I. A. A enfermeira-Ananéri no "País do Futuro": a aventura da luta contra a tuberculose. (Tese de Doutoramento). Rio de Janeiro: UFRJ, Escola de Enfermagem Anna Nery, 1992.

KOSOVSKI, E; BARATA, A. et. al. Ética na comunicação. Rio de Janeiro: MAUAD, 1995.

LINDBERG, C. As Reformas na Europa. Tradução de Luiz Henrique Dreher e Luis Marcos Sander. São Leopoldo: Sinodal, 2001.

LOPEZ-BARALT, L. Huellas del Islam en la literatura espanola. Madrid: Hiperión, 1985.

LOWEN, A. Uma vida para o corpo: autobiografia de Alexander Lowen. Tradução de Maria Silvia Mourão Netto. São Paulus: Summus, 2007. 
LUCAS, M.C.A. A Literatura Visionária na Idade Média Portuguesa. Lisboa: Biblioteca Breve, ICLP (Instituto de Cultura e Língua Portuguesa), 1986.

MIRANDA, A. R. Mary Wollstonecraft e a reflexão sobre os limites do pensamento liberal e democrático a respeito dos direitos femininos (1759-1797). Dissertação (Mestrado). Curitiba: Universidade Federal do Paraná, Departamento de Letras. 2010.

MORAS, A. Os entes sobrenaturais na Idade Média: Imaginário, representações e ordenamento social. São Paulo: Anna Blume, 2001.

MÜLLER, M. J. Merleau-Ponty: acerca da expressão. Porto Alegre: EDIPUC, 2001.

NERY, M.C.R. Sociologia, a Ciência da crise. IN: TESKE, O. (Coord). Sociologia: textos e contextos. Canoas: ULBRA, 1999.

NODARI, P. C. A emergência do individualismo moderno no pensamento de John Locke. Porto Alegre: EDIPURS, 1999.

NOVINSKY, A. W. A inquisição. São Paulo: Brasiliense, 1994.

OLIVEIRA, E. G. Educação à distância na transição paradigmática. Campinas: Papirus, 2003. (Coleção Magistério: Formação e Trabalho Pedagógico)

PFANDL, L. Cultura y costumbres del pueblo espanõl de los siglos XVI e XVII: Introducción al estudio del siglo de oro. Barcelona: [s.e.], 1959.

RABAÇA, S. R. Variantes críticas: a dialética do esclarecimento e o legado da escola de Frankfurt. São Paulo: Anna Blume, 2004.

SÁ. D. S. de. Gótico Tropical: o sublime e o demoníaco em O guarani. Salvador: EDUFBA, 2010.

SANTUCCI, J. Mulheres Médicas: As pioneiras da medicina. Rio de Janeiro: Ediouro, 2005.

SILVA, S. V. As Religiões no Brasil. In: BRANDÃO, S. História das Religiões no Brasil. vol. I. PERNAMBUCO: Editora Universitária da UFPE, 2001.

SILVA, L. A. Redação: qualidade na comunicação escrita. 10. ed. Curitiba: Ibpex, 2005.

SPERANDIO, M. R. G. Para entender pós-modernidade. São Leopoldo: Sinodal, 2007.

TELLEZ, E. V. Crítica filosófica: Estudio bibliográfico y crítico de las obras de filosofia, escritas traducidas o publicadas en México desde ele siglo XVI hasta nuestros días. México: [s.e], 1904. 
TERRA, E. G. Literatura \& redação para o Ensino Médio. São Paulo: Editora Scipione, 1997.

TESKE, O. (Coord). Sociologia: textos e contextos. Canoas: ULBRA, 1999.

THA, F. Categorias conceituais da subjetividade. São Paulo: Annablume, 2007.

O'CONNELL, M. R. Critics on Trial: An Introduction to the catholic Modernist Crisis. United States of América: Liberary if Cibgress Catalogin- in-publication Data.

\section{Dicionários, Vocabulários e Compêndios}

ÁLVAREZ, T. Diccionario de Santa Teresa. Doctrina e Historia. Burgos: Monte Carmelo, 2002.

BALDINI, M. Linguagem Mística. In: BORRIELLO, L. et al. Dicionário de mística. São Paulo: Loyola/Paulus, 2003.

BASTÚS, V. J. Suplemento al Diccionario histórico enciclopédico. Barcelona, 1833.

BIBLIOTECA MÍSTICA CARMELITANA. Procesos de beatificación y Canonización de Santa Teresa de Jesús. Burgos: Monte Carmelo, 1935. 3 Tomos. (BMC 18,19 e 20. Editados e anotados por Frei Silvério de Santa Teresa]. BORRIELlO, L. et. al. Dicionário de Mística. São Paulo: Loyola/Paulus, 2003. BOVE, G. Iluminação. In: MANCUSO, V.; PACOMIO, L. (Orgs.). Lexicon: Dicionário Teológico Enciclopédico. Tradução: João Paixão Neto e Alda da Anunciação Machado. São Paulo: Loyola, 2003.

FERRATER MORA, J. Dicionário de Filosofia. Nova Edição revisada, aumentada e atualizada pelo professor Josep-Maria Terricabras. Supervisão profa. Priscilla Cohn Ferrater Mora. vol. I. 2. ed. São Paulo: Brasil, 2001.

FROGGIO G.; PACCIOLA, A. In: BORRIELLO, L. et. al. Dicionário de mística. São Paulo: Loyola/Paulus, 2003.

KAPLAN, H. I.; SADOCK, B. J. Compêndio de Psiquiatria. Porto Alegre: Artes Médicas, 1990.

LARKIN, E. Espiritualidade. In: BORRIELLO, L. et. al. Dicionário de Mística. São Paulo: Loyola/Paulus, 2003.

LÉON-DUFOUR, X. (Dir.). Vocabulário de Teologia Bíblica. 2. ed. Petrópolis: Vozes, 1977. 
MACCISE, C. Mística na Revelação bíblica. In: BORRIELLO, L. et. al. Dicionário de Mística. São Paulo: Paulus/Loyola, 2003. (Dicionário).

MANCUSO, V.; PACOMIO, L. (Orgs.). Lexicon: Dicionário Teológico Enciclopédico. Tradução: João Paixão Neto e Alda da Anunciação Machado. São Paulo: Loyola, 2003.

MARCOZZI, V. Discernimento dos espíritos. In: BORRIELLO, L. et. al. Dicionário de Mística. São Paulo: Loyola/Paulus, 2003.

McKENZIE, J. L. Dicionário Bíblico. 5. ed. São Paulo: Paulus, 1983.

ROUDINESCO, E. Charcot, Jean Martin. In: ROUDINESCO, E. et. al. Dicionário de psicanálise. Tradução Vera Ribeiro, Lucy Magalhaes. Supervisão da edição brasileira Marco Antônio Coutinho Jorge. Rio de Janeiro: Zahar, 1998. ROUDINESCO, E. Ilusão. In: ROUDINESCO, E. et. al. Dicionário de psicanálise. Tradução Vera Ribeiro, Lucy Magalhaes. Supervisão da edição brasileira Marco Antônio Coutinho Jorge. Rio de Janeiro: Zahar, 1998 ROUDINESCO, E. O futuro de uma ilusão. In: ROUDINESCO, E. et. al. Dicionário de psicanálise. Tradução Vera Ribeiro, Lucy Magalhaes. Supervisão da edição brasileira Marco Antônio Coutinho Jorge. Rio de Janeiro: Zahar, 1998. ROUDINESCO, E. et. al. Dicionário de psicanálise. Tradução Vera Ribeiro, Lucy Magalhaes. Supervisão da edição brasileira Marco Antônio Coutinho Jorge. Rio de Janeiro: Zahar, 1998.

RODRIGUEZ, A. A.; CANALS CASAS, J. et. al. Dicionário Teológico da Vida Consagrada. São Paulo: Paulus, 1994.

RUIZ SALVADOR, F. Compêndio de Teologia Espiritual. Título original: Caminos del espíritu. Revisão Célia Regina Faria Menin; Sandra Garcia. São Paulo: Loyola. 1996.

SHÜLleR, A. et. al. Dicionário Enciclopédico de Teologia. Canoas: Ed. ULBRA, 2002.

TENSEK, T. Z. Discernimento. In: MANCUSO, V.; PACOMIO, L. (Orgs.). Lexicon: Dicionário Teológico Enciclopédico. Tradução: João Paixão Neto e Alda da Anunciação Machado. São Paulo: Loyola, 2003.

VANZAN, P. Dessecularização-Ressacralização. In: BORRIELLO, L. et. al. Dicionário de Mística. São Paulo: Loyola/Paulus, 2003. 


\section{Periódicos}

ARAGÃO, G. Inculturação da fé cristã na religiosidade popular. In: Vida Pastoral. São Paulo: Paulus, 2013. ano 54. março-abril. n. 289.

CAMINERO, J. Dialéctica de la experiencia y la erudición en el proceso místico de Santa Teresa. Letras de Deusto, Bilbao, vol. 12, n. 24, jul/dez. 1982.

CASTRO SÁNCHEZ, S. (Org.) Teresa de Jesús: Presencia Permanente. Revista de Espiritualidad. n. 222-223. ene/jun. 1997.

MORAES, J. M. Uma luz que para uns brilha e para outros ofusca no fim do túnel. Revista Veiga Mais. Edição Otimismo. Ano 3. n. 5, 2004-1.

PEREIRA, A. S. O herói guerreiro cristão: fé coragem e território. In: A historiografia Religiosa Medieval hoje: temas e problemas. Lusitania Sacra. Revista do Centro de Estudos de Historia Religiosa Universidade Católica Portuguesa. 2. Série. Tomo XIII-XIV. Lisboa: Sersilito Empresa Gráfica, 1998. REVISTA ECLESIÁSTICA BRASILEIRA/REB. Critérios para discernimento de visões, aparições. v. 59; ed. 233-234. pp. 14 e 46.

SANROMÁN, J. B. Anteriores Centenários de la muerte de Santa Teresa. Revista de Espiritualidad: Santa Teresa en su ambiente histórico. Madrid: vol. 40. n. 159160 .

TORRES SÁNCHEZ, S. Mística y cristología en Santa Teresa. In: CASTRO, S. (Org.). Teresa de Jesús. Presencia Permanente. Revista de Espiritualidad. n. 222223. ene/jun. Madrid, 1997.

VIDA PASTORAL. São Paulo: Paulus, 2013. ano 54. março-abril. n. 289.

\section{Referências Eletrônicas}

BOTEllA, C; BOTELlA, S. Místico, conhecimento e trauma. Rev. bras. psicanál, São Paulo, v.43,n.3, set.2009.Disponível em <http: // pepsic. bvsalud. org/ scielo. php? Script =sci _ arttext \&pid=S0486641X2009000300016\&lng=pt\&nrm=iso>. Acessado em 05.06.2012, às 12h.

FORMIGA, N.; MELLO, I. Testes psicológicos e técnicas projetivas: uma integração para um desenvolvimento da interação interpretativa indivíduopsicólogo. Psicol. cienc. prof. [online]. 2000, vol.20, n.2, pp. 12-19. ISSN 14149893. Disponível em http://dx.doi.org/10.1590/S1414-98932000000200004. Acessado em 27.05.20123, às 17h05min. 
HERRAIZ, M. Santa Teresa de Ávila, amiga de Deus e dos homens. Disponível em http://www.comshalom.org/formacao/santos/sta_tereza.html. Acessado em 06.05.2012, às $18 \mathrm{~h}$.

INSTITUIÇÃO TERESIANA. São Pedro Poveda. Disponível em: http://www.institucionteresiana.com/index.php?option=comcontent $\&$ view=article $\& i d=57 \&$ Itemid=80\&lang=es. Acessado em 27.05.2012, às 13h40min.

LA CIGOÑA, J. R. F. Nos umbrais da mística. Disponível em http://www.clfc.puc-rio.br/artigo9.html. Acessado em 24.10.2012, às 10h; 19.03.2013, às 19h; 16.05.2013, às 19h29min; em 16.07.2013, às 11h.

LYRA, S. R. Psicologia e vida mística. Jornal da Universidade. Ed. 147 março 2012. Disponível em http://www.ichthysinstituto.com.br /artigosdetalhe. asp?ID=77. Acessado em 25.08.2012, às 14h.

PEDROSA-PÁDUA, L. Mãe da Psicologia subjetividade e liberdade. Disponível em htpp://www.ihu. unisinos.br/entrevistas/505364-em edição-mae-da-psicologiacubjetividade-liberdade-e-autonomia-em-teresa-de-jesus-entrevista-especial-com -lucia-pedrosa. Acessado em 12 de maio 2012, às 14h; às 18h.

PIRES, R. E. Erotismo e religião: um diálogo instigante. Rev. bras. Psicanál. São Paulo, v. 41, n. 2, jun. 2007. Disponível em http://pepsic.bvsalud.org/scielo. php?script=sci_arttext \&pid=S0486-641X2007000200013\&lng=pt\&nrm=iso > Acessado 18.05. 2012, às 15h10min.

PRAXEDES, G.; PEDUZZI, L. O. Q. Tycho Brahe e Kepler na escola: uma contribuição à inserção de dois artigos em sala de aula. Rev. Bras. Ensino Fís. [online]. 2009, vol.31, n.3, pp. 3601.1-3601.10. Epub Sep 25, 2009. ISSN 18061117. Disponível em http://dx.doi.org/10.1590/S1806-11172009005000001. Acessado em 05.05.2013, às 9h.

SANTOS, R. P. Biografia de Isaac Newton. Disponível em http://www.fisicainteressante.com/biografia-isaac-newton.html. Acessado em 19.03.2012, às 9h.

VANDERMOERE, J. Acta Sanctorum Teresiae a Jesu. Carmeitarum strictioris observantiae parentis. Commentario et Observationibus illustrata. Bruxellis, 1845. n. 96. p. 2. Documento on line. Disponível em http:// books. google. com.br/ books?id=uBYJIkQzwc8C\&pg=PA2\&dq=VANDERMOERE,+J.+Acta+Sanctoru

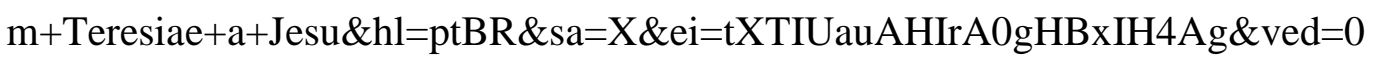
CDMQ6AEwAA\#v=onepage $\& q=V A N D E R M O E R E \% 2 C \% 20 \mathrm{~J} . \% 20 \mathrm{Acta} \% 20 \mathrm{San}$ ctorum\%20Teresiae\%20a\%20Jesu\&f=false. Acessado em 19.03.2013, às 15h. 